\title{
MICROCOSM STUDY OF NATURAL ATTENUATION, BIOSTIMULATION, AND BIOAUGMENTATION OF SOILS CONTAMINATED WITH PCBS, DIOXINS, PAHS, AND PETROLEUM HYDROCARBONS
}

\author{
A Thesis \\ presented to \\ the Faculty of California Polytechnic State University, \\ San Luis Obispo
}

In Partial Fulfillment

of the Requirements for the Degree

Master of Science in Civil and Environmental Engineering

by

Mackenzie L. Billings

December 2014 
(C) 2014

Mackenzie Billings

ALL RIGHTS RESERVED 


\section{COMMITTEE MEMBERSHIP}

TITLE:

Microcosm Study of Natural Attenuation, Biostimulation, and Bioaugmentation of Soils Contaminated with PCBs, Dioxins, PAHs, and Petroleum Hydrocarbons

AUTHOR:

Mackenzie L. Billings

DATE SUBMITTED: December 2014

COMMITTEE CHAIR: $\quad$ Yarrow Nelson, Ph.D.

Professor of Environmental Engineering

COMMITTEE MEMBER: Nirupam Pal, Ph.D.

Assistant Professor of Environmental Engineering

COMMITTEE MEMBER: Chris Kitts, Ph. D.

Professor of Biological Sciences 


\begin{abstract}
Microcosm Study of Natural Attenuation, Biostimulation, and Bioaugmentation of Soils Contaminated with PCBs, Dioxins, PAHs, and Petroleum Hydrocarbons Mackenzie L. Billings

The potential for bioremediation of weathered petroleum hydrocarbons, polycyclic aromatic hydrocarbons (PAHs), dioxins, and polychlorinated biphenyls (PCBs) was assessed using laboratory-scale microcosms with contaminated soils from the Santa Susana Field Laboratory (SSFL) in southern California. These contaminants of interest (COIs) have persisted in these soils for over 40 years in some cases. The objective of this United States Department of Energy (DOE)-funded study was to determine the potential of natural attenuation, in-situ biostimulation, and/or bioaugmentation remediation methods to reduce COI concentrations in soil and estimate potential biodegradation rates of COIs in SSFL soils.
\end{abstract}

Several types of soil microcosms were established: one set of microcosms was run without amendments to estimate natural attenuation rates at the site; biostimulation was tested by addition of nitrogen and phosphorus, rice hulls, and/or biosurfactant (soya lecithin), another set was augmented with the white-rot fungus Phanerochaete chrysosporium, and gamma-irradiated microcosms served as sterilized controls. Soil samples were collected and analyzed for dioxins, PCBs, PAHs, and extractable fuel hydrocarbons (EFH) after 0, 4, and 8 months of incubation. Soil contamination in the microcosms initially consisted of primarily heavily chlorinated dioxins and PCBs, longerchain petroleum hydrocarbons (21-40 equivalent carbon chain length), and PAHs with 46 aromatic rings. 
Small decreases in PAH, PCB, and dioxin soil concentrations were observed, but these decreases were not statistically significant over the time period of the microcosm experiments. EFH concentrations were inflated at the final sampling event, but they appeared to reduce for two of three soils tested at the second sampling (4 months). Because petroleum hydrocarbons were primarily longer-chain hydrocarbons in the $\mathrm{C} 21$ to C40 EFH range, it is likely that lighter hydrocarbons had been preferentially degraded, leaving the more recalcitrant longer-chain hydrocarbons in the soil. Larger PAHs (4-6 rings) comprise the majority of residual PAH soil contamination in the soils collected from the field site. These PAH concentrations did not decrease significantly during this 8-month long study; it is likely that these larger PAH compounds are somewhat recalcitrant and will take a long time to biodegrade. Similarly, little or no PCB biodegradation was observed, which is not surprising because the PCBs are heavily chlorinated, and bacterial biodegradation of these highly chlorinated compounds is reported to occur only under anaerobic conditions which were not observed in the field or in microcosms. Dioxin concentrations appeared to decrease in some cases, but these reductions were not statistically significant at the $95 \%$ confidence level. The primary dioxin congener present in soils was octachlorodibenzodioxin (OCDD), which is the heaviest-chlorinated dioxin congener. Like PCBs, this compound requires anaerobic conditions for reductive dechlorination, and these are not present at the site. Total dioxin concentrations decreased in the microcosms amended with Phanerochaete chrysosporium, although this decrease was not statistically significant due to variability of dioxin concentrations measured in the soil. No decrease in tetrachlorodibenzodioxin 
(TCDD) toxicity equivalence (TEQ) was observed with P. chrysosporium bioaugmentation, and this parameter is important in terms of dioxin toxicity.

Soil vapor analyses performed at the site indicate highly aerobic soil conditions. To mimic site conditions as closely as possible, experimental microcosms were also maintained under aerobic conditions. Although fungi have been reported to degrade PCBs and dioxins under aerobic conditions, the microcosms augmented with Phanerochaete chrysosporium did not show statistically significant biodegradation of PCBs.

Contaminant sequestration in the soil may also have contributed to the lack of observed biodegradation because the COIs at this site are highly weathered. However, even microcosms augmented with a surfactant (soya lecithin), which would be expected to solubilize sequestered COIs, did not show significant biodegradation. 


\section{ACKNOWLEDGMENTS}

I would like to thank my advisor Dr. Yarrow Nelson for his patience and guidance throughout this project. I would also like to thank Dr. Chris Kitts for his advice and insight regarding experimental design and soil microbes, and Dr. Nirupam Pal for his insight on lignin-degrading organisms. My statistical analysis of the data presented in this thesis would not have been possible without Dr. Jeff Sklar. I am grateful for CDM Smith's help throughout this project: Dr. Keegan Roberts's lighthearted supervision made work into play, John Wondolleck offered cut and dry decision-making and data evaluation that kept things in perspective, and Pam Hartman provided endless sanity checks through grueling sampling. Matt Poltorak and Kenneth Croyle, I am so glad that in working together we became good friends. I would like to thank my family for their support and patience throughout this chapter of my life, and I would like to thank my dog for her unconditional love and ever-wagging tail. Finally, I would like to thank the Department of Energy for their support and funding of this work. 


\section{TABLE OF CONTENTS}

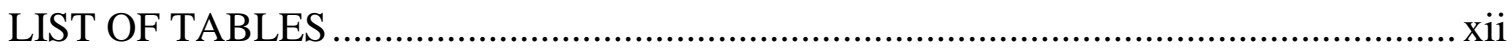

LIST OF FIGURES …..............................................................................

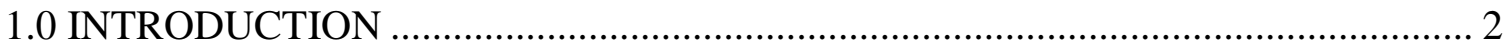

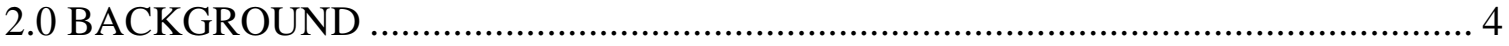

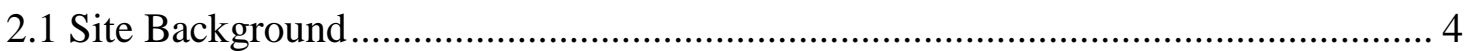

2.2 Site Contamination Characterization .............................................................. 5

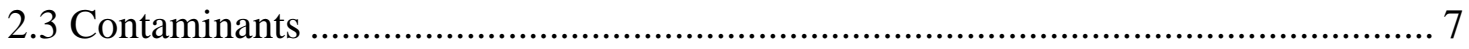

2.3.1 Petroleum Hydrocarbons ........................................................................ 7

2.3.2 Polycyclic Aromatic Hydrocarbons ................................................................. 9

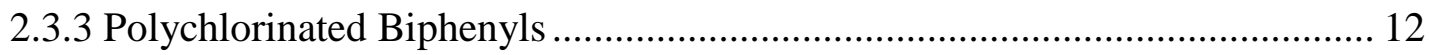

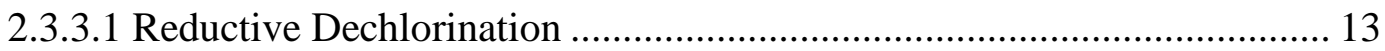

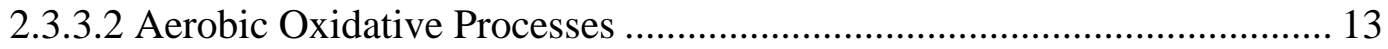

2.3.3.3 Combining Anaerobic and Aerobic Processes .................................... 13

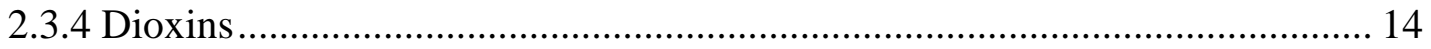

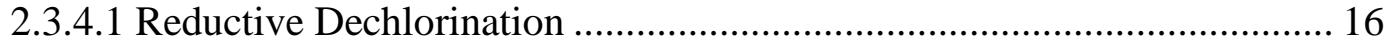

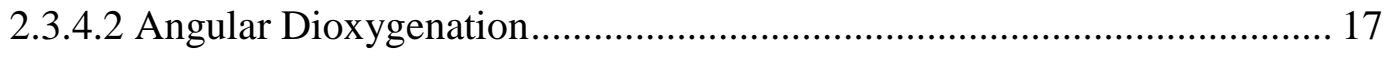

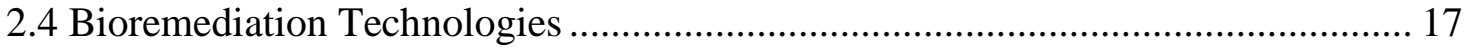

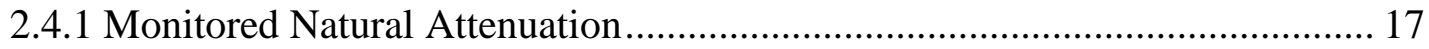

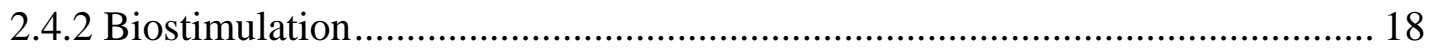




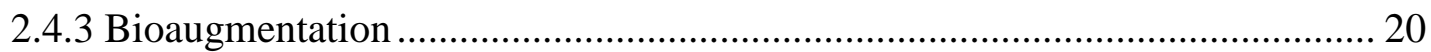

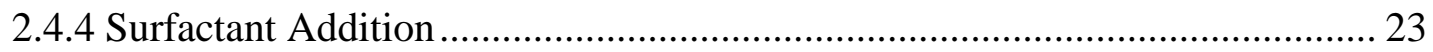

2.4.5 Combined Treatments......................................................................... 26

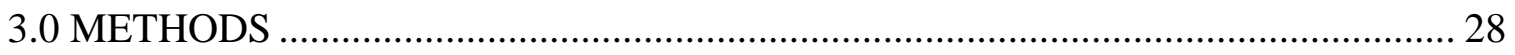

3.1 Soil Sampling Site Selection and Prescreening Soil Collection ............................ 28

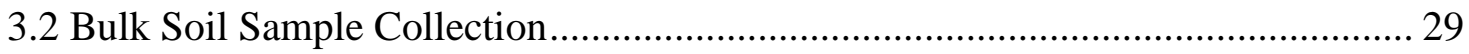

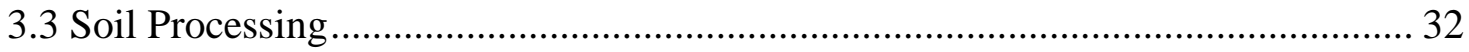

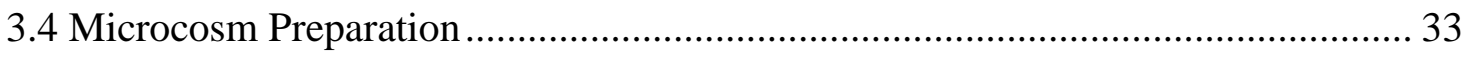

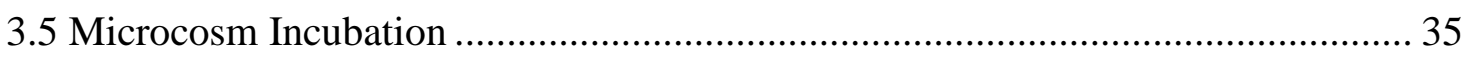

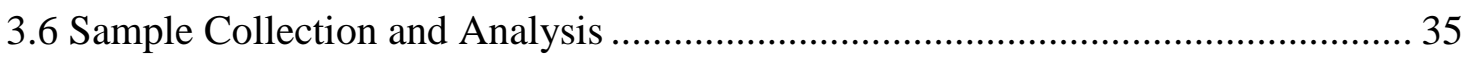

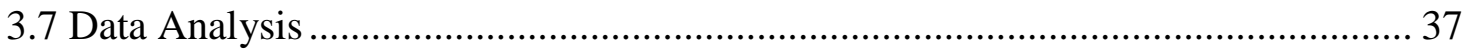

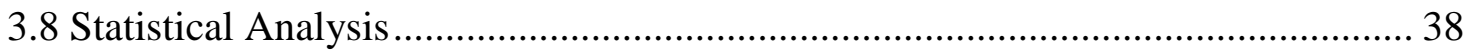

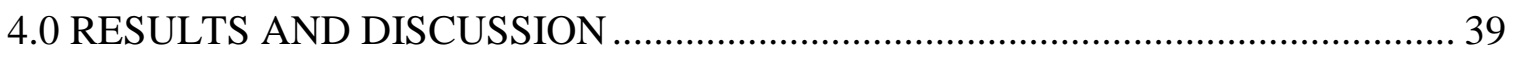

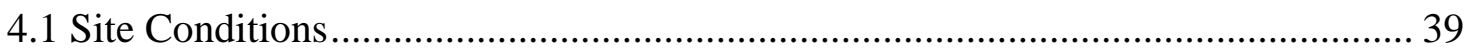

4.1.1 Soil Gas Composition ............................................................................ 39

4.1.2 Soil Temperature ....................................................................................... 40

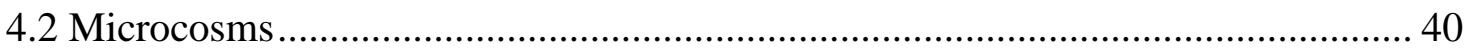

4.2.1 Characterization of Soils used for Microcosms ………................................... 40

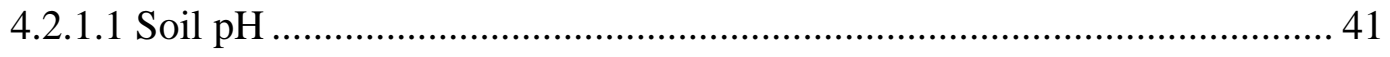

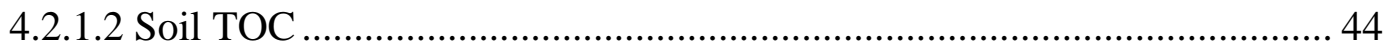




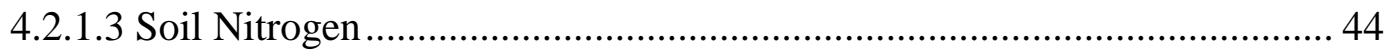

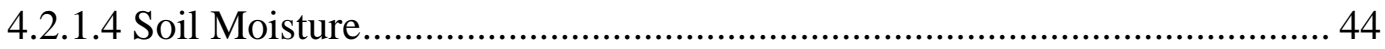

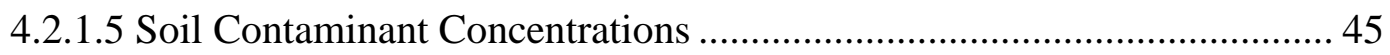

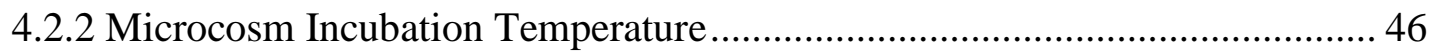

4.2.3 Contaminant Soil Concentrations in Microcosms During Incubation .............. 47

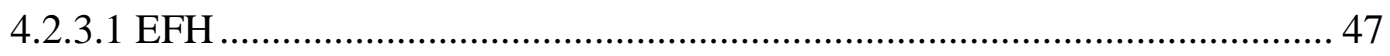

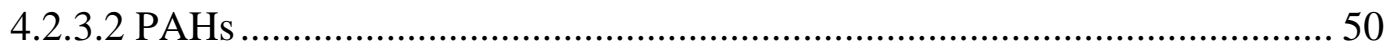

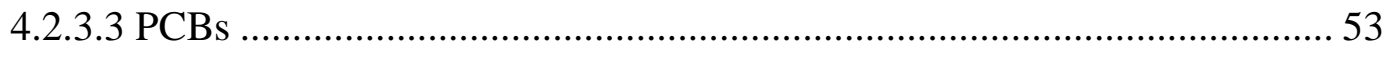

4.2.3.4 Chlorinated Dioxins and TCDD TEQ.................................................. 56

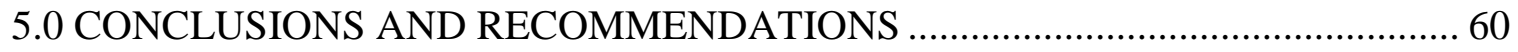

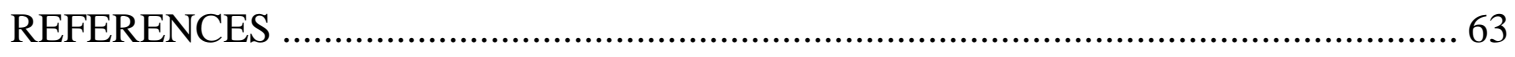

\section{APPENDICES}

Appendix A: Bar Graphs of EFH Equivalent Carbon Ranges.......................................... 74

Appendix B: Bar Graphs of Individual Dioxin Congener Concentrations ....................... 81

Appendix C: Bar Graphs of Individual PAH Compound Concentrations .......................... 95

Appendix D: Bar Graphs of Aroclor Concentrations ................................................. 120

Appendix E: Microcosm Incubator Temperature Electronic Data Sheet ....................... 126

Appendix F: Statistics: Effect of Treatment on Changes in Soil A COIs....................... 133

Appendix G: Statistics: Effect of Gamma Irradiation on Changes in Soil A COIs ........ 146

Appendix H: Statistics: Effect of Soil Type (A, B, or C) on COIs ................................. 158

Appendix I: Microcosm Data and Graphs .............................................................. 168 
Appendix J: Microcosm Soil Temperature Log.

Appendix K: COI Concentrations, Standard Deviation, and Standard Error .................. 180

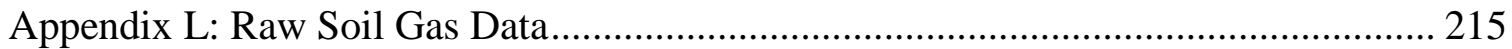

Appendix M: Kinetics Estimations Using Microcosm Data............................................ 220 


\section{LIST OF TABLES}

Table 1: Historic Area IV contaminant concentrations vary widely across the site ....................... 5

Table 2: Minimum and maximum biodegradation rates reported for soil and marine organisms... 8

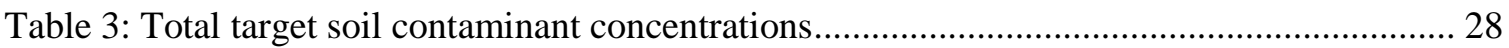

Table 4: Microcosm soil locations and sampling frequency (5 replicates per Microcosm ID) ..... 34

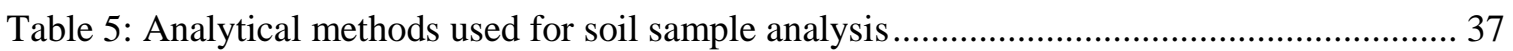

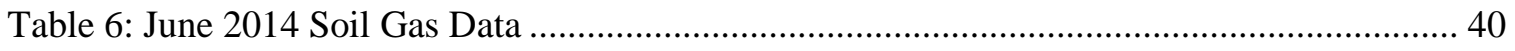

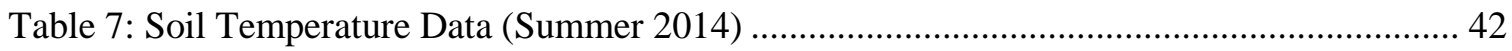

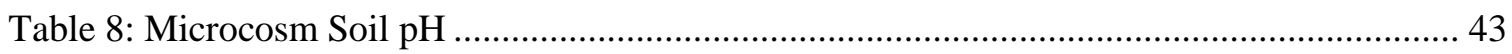

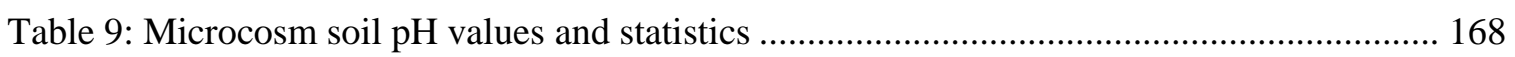

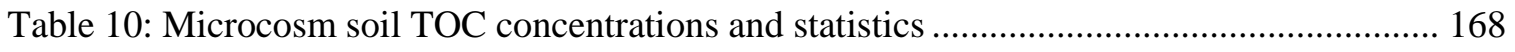

Table 11: Microcosm soil Nitrate/Nitrate concentrations and statistics .................................... 170

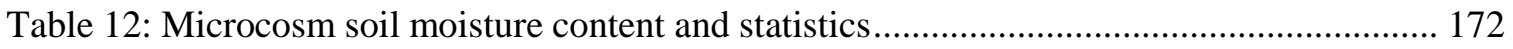

Table 13: Microcosm soil total EFH concentrations and statistics.......................................... 174

Table 14: Microcosm total PAH concentrations and statistics ................................................. 175

Table 15: Microcosm soil total PCB concentrations and statistics .......................................... 176

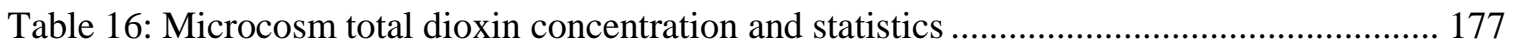

Table 17: Microcosm soil TCDD TEQ concentrations and statistics........................................ 178

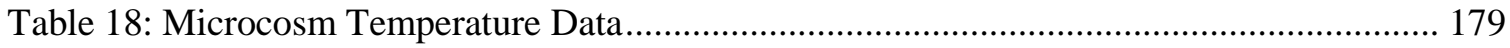

Table 19: Individual compound concentration including standard deviation and error .............. 180

Table 20: Total EFH concentration in microcosms during incubation....................................... 209

Table 21: Total PAH concentration in microcosms during incubation ..................................... 210

Table 22: Aroclor 1260, 5460, and 1254 concentrations in microcosms during incubation ....... 211

Table 23: Total dioxin concentration in microcosms during incubation ..................................... 213

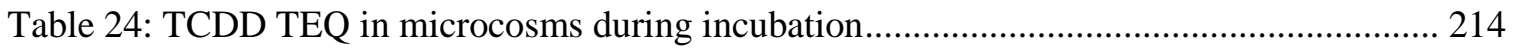

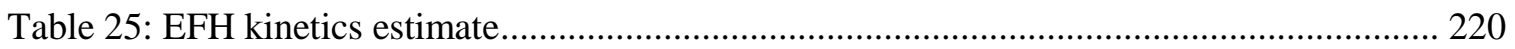




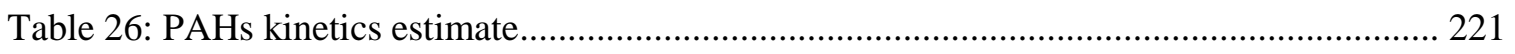

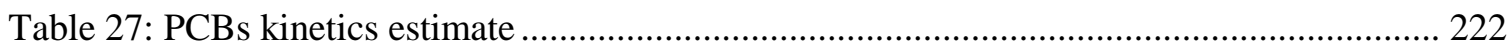

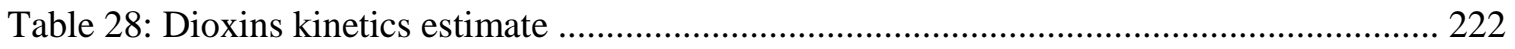




\section{LIST OF FIGURES}

Figure 1: Major hydrocarbon biodegradation pathway (Fritsche and Hofrichter 2000) ................ 9

Figure 2: Stainless steel shovels and bulk soil collection buckets (Teflon liners not shown) ....... 30

Figure 3: Organic vapor and radiation levels were monitored throughout sample collection....... 30

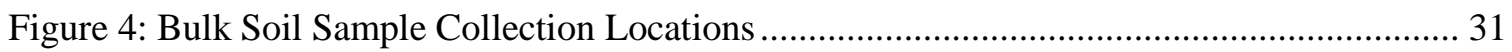

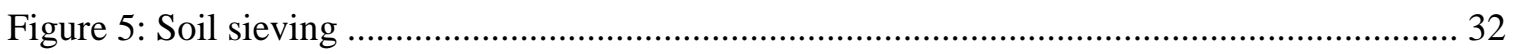

Figure 6: Soil sample processing: labeling and completing the chain of custody ........................ 35

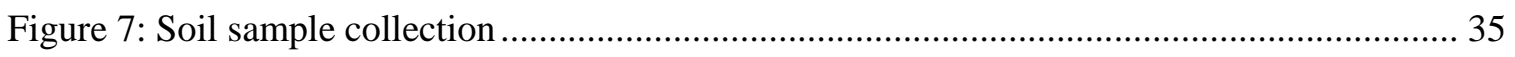

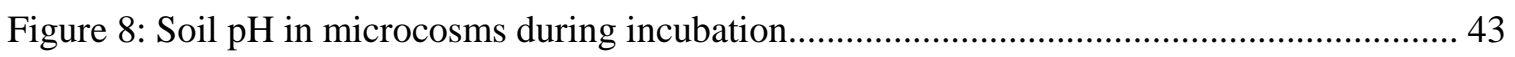

Figure 9: Microcosm incubator temperature during experiment ............................................ 46

Figure 10: Total EFH concentration during microcosm incubation .......................................... 49

Figure 11: Total PAH concentration during microcosm incubation ......................................... 51

Figure 12: Total PAH concentration during microcosm incubation (A and C)........................... 52

Figure 13: Aroclor 1260 concentration during microcosm incubation ...................................... 55

Figure 14: Total dioxin concentration during microcosm incubation ........................................ 58

Figure 15: TCDD TEQ concentration during microcosm incubation ........................................ 59

Figure 16: C8-C11 EFH equivalent carbon ranges during microcosm incubation........................ 74

Figure 17: EFH C12-C14 concentrations during microcosm incubation .................................... 75

Figure 18: EFH C15-C20 concentrations during microcosm incubation .................................... 76

Figure 19: Truncated EFH C15-C20 concentrations during microcosm incubation ...................... 77

Figure 20: EFH C21-C30 concentrations during microcosm incubation ..................................... 78

Figure 21: Truncated EFH C21-C30 concentrations during microcoms incubation ...................... 80

Figure 22: EFH C30-C40 concentrations during microcosm incubation .................................... 81

Figure 23: 1,2,3,4,6,7,8 HpCDD concentrations during microcosm incubation ......................... 82

Figure 24: 1,2,3,4,6,7,8 HpCDF concentrations during microcosm incubation.......................... 82

Figure 25: 1,2,3,4,7,8,9 HpCDF concentrations during microcosm incubation.......................... 83 
Figure 26: 1,2,3,4,7,8 HpCDD concentrations during microcosm incubation

Figure 27: 1,2,3,4,7,8 HxCDF concentrations during microcosm incubation. 85

Figure 28: 1,2,3,6,7,8 HxCDD concentrations during microcosm incubation 86

Figure 29: 1,2,3,6,7,8 HxCDF concentrations during microcosm incubation 87

Figure 30: 1,2,3,7,8,9 HxCDD concentrations during microcosm incubation 88

Figure 31: 1,2,3,7,8,9 HxCDF concentrations during microcosm incubation. 90

Figure 32: 1,2,3,7,8 PeCDF concentrations during microcosm incubation 91

Figure 33: 1,2,3,7,8 PeCDD concentrations during microcosm incubation 92

Figure 34: 2,3,4,6,7,8 HxCDF concentrations during microcosm incubation. 92

Figure 35: OCDD concentrations during microcosm incubation 93

Figure 36: Truncated OCDF concentrations during microcosm incubation 94

Figure 37: 1,1'-biphenyl concetrations during microcosm incubation 95

Figure 38: Benzo(a)anthracene concentrations during microcosm incubation (all soils) 96

Figure 39: Benzo(a)anthracene during incubation (A and C) 97

Figure 40: Benzo(a)pyrene concentrations during microcosm incubation (all soils) 98

Figure 41: Benzo(a)pyrene concentrations during microcosm incubation (A and C) 100

Figure 42: Benzo(b)fluoranthene concentrations during microcosm incubation (all soils) ........ 101

Figure 43: Benzo(b)fluoranthene concentrations during microcosm incubation (A and C) ....... 102

Figure 44: Benzo(e)pyrene concentrations during microcosm incubation (all soils) 102

Figure 45: Benzo(e)pyrene concentrations during microcosm incubation (Soils A and C)........ 103

Figure 46: Benzo(g,h,i)perylene concentrations during microcosm incubation (all soils).......... 104

Figure 47: Benzo(g,h,i)perylene concentrations during microcosm incubation (A and C)......... 105

Figure 48: Benzo(k)fluoranthene concentrations during microcosm incubation (all soils) ........ 106

Figure 49: Benzo(k)fluoranthene concentrations during microcosm incubation (A and C) ....... 107

Figure 50: Chrysene concentrations during microcosm incubation (all soils) .......................... 108

Figure 51: Chrysene concentrations during microcosm incubation (A and C) 109 
Figure 52: Dibenzo(a,h)anthracene concentrations during microcosm incubation (all soils) ..... 110

Figure 53: Dibenzo(a,h)anthracene concentrations during microcosm incubation (A and C) .... 111

Figure 54: Fluoranthene concentrations during microcosm incubation (all soils) ..................... 112

Figure 55: Flouranthene concentrations during microcosm incubation (A and C) .................... 113

Figure 56: Fluorene concentrations during microcosm incubation (all soils) ............................ 114

Figure 57: Fluorene concentrations during microcosm incubation (A and C) .......................... 115

Figure 58: Indeno(1,2,3-cd)pyrene concentrations during microcosm incubation (all soils)...... 116

Figure 59: Indeno(1,2,3-cd)pyrene concentrations during microcosm incubation (A and C).... 117

Figure 60: Methanamine, n-methyl n-nitroso concentrations during microcosm incubation...... 118

Figure 61: Naphthalene concentrations during microcosm incubation (all soils) ...................... 119

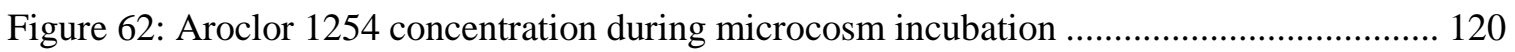

Figure 63: Truncated Aroclor 1254 concentrations during microcosm incubation...................... 121

Figure 64: Aroclor 1260 concentrations during microcosm incubation ...................................... 122

Figure 65: Truncated Aroclor 1260 concentrations during microcosm incubation..................... 123

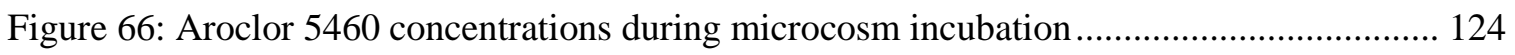

Figure 67: Truncated Aroclor 5460 concentrations during microcosm incubation..................... 125

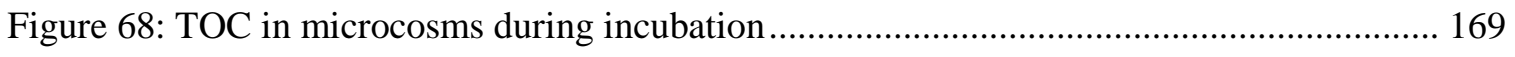

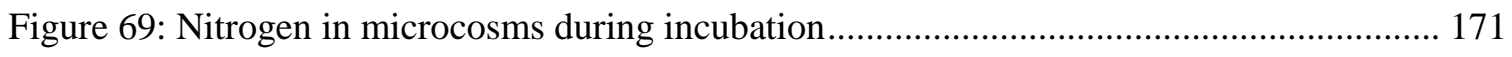

Figure 70: Microcosm moisture content during incubation ................................................ 173 


\section{GLOSSARY}

2,3,7,8-TeCDD 2,3,7,8-Tetrachlorodiebnzo-p-dioxin

bgs beneath ground surface

AI North American Aviation's Atomic International

AOC Administrative Order on Consent

COI Contaminant of interest

DD/DF Dibenzodioxins/dibenzofurans

DOE United States Department of Energy

EPA Environmental Protection Agency

EFH Extractable fuel hydrocarbons

$\mathrm{ft}$ feet

Heptachlorodibenzo-p-dioxin (HpCDD)

NASA National Aeronautics and Space Administration

OCDD Octachlorodibenzodioxin

PCDD Polychlorinated dibenzo-p-dioxins

PCDF Polychlorinated dibenzofurans

PHCs petroleum hydrocarbons

PAHs polycyclic aromatic hydrocarbons

PCBs polychlorinated biphenyls

SSFL Santa Susana Field Laboratory

STIG Soil Treatability Interest Group 
TCDD TEQ Tetrachlorodibenzodioxin toxicity equivalence

TEF Toxic Equivalent Factor

w/w weight by weight 


\subsection{INTRODUCTION}

Santa Susana Field Laboratory (SSFL) is a historic rocket fuel, nuclear reactor, and liquid metals testing site. The Department of Energy (DOE) is one of three parties (Boeing, DOE, and the National Aeronautics and Space Administration, or NASA) responsible for mitigating soil contamination resulting from historic SSFL activities. Contamination includes dioxins, herbicides, metals, petroleum hydrocarbons (PHCs), polycyclic aromatic hydrocarbons (PAHs), perchlorate, pesticides, PCBs, and radionuclides. In 2010, the OE signed an Administrative Order on Consent (AOC) with the California Environmental Protection Agency that requires DOE to reduce contamination levels to background levels specified in a Chemical Look-Up Table (Look-Up Table) provided in a May 21, 2013 technical memorandum by the Department of Toxic Substances Control.

Sandia recommended five soil remediation technologies to assess in future studies: bioremediation, natural attenuation, phytoremediation, soil partitioning, and mercury volatilization. For the bioremediation study, Sandia recommended the following treatment study tasks: determine what biota/microbiota are currently present in Area IV soils; the rate of biologic degradation, if any, for the various contaminants in the affected soils; what nutrients/additives can be used to stimulate/increase native biota/microbiota degradation rates (i.e. biostimulation); and what non-native biota/microbiota could be used to degrade existing contaminants without interfering with native biota.

Following the recommendation of Sandia National Laboratories, this study investigated the rates of biologic degradation of dioxins, PAHs, PCBs, and PHCs observed in laboratory microcosm experiments. Natural attenuation rates were 
investigated by incubating two different soils from the site without amendments. Biostimulation was tested on another soil from the site through nutrient, biosurfactant, and bulking agent amendment of soils. Bioaugmentation was explored by amending one set of microcosms with the white-rot fungi Phanerochaete chrysosporium, which has been shown to facilitate biodegradation of PCBs and dioxins under aerobic conditions. To observe changes in soil concentrations due to abiotic factors, control microcosms were sterilized using Cobalt-60 gamma irradiation.

Site conditions and soil quality assessments provide indispensable information that can shed light on the biodegradability limitations of contaminants at a given site. These data can be used in conjunction with microcosm sampling data to determine whether or not biodegradation of contaminants is occurring at a given site. Soil temperature and gas data were collected and mimicked during microcosm incubation.

Three different soils were collected from the site, homogenized, and placed in 4-L glass microcosms with amendments. Microcosms consisted of 4-L glass jars sealed with Teflon-lined lids, soil at $15 \%$ moisture, and soil amendments. The microcosms were incubated at temperatures representative of the field site under aerobic conditions. Soils were sampled at 0,126 , and 244 days after experiment startup to observe any changes in soil contaminant concentrations. A companion study characterized the microbial communities in SSFL soils and revealed that SSFL soils contain significant populations of microbes that can degrade PHCs aerobically (Croyle 2014). Several strains of fungi were identified which have been reported to mediate cometabolic biodegradation of PAHs, PCBs, and dioxins, but bacteria associated with biodegradation of these compounds were not detected (Croyle 2014). 


\subsection{BACKGROUND}

\subsection{Site Background}

SSFL was established in 1947 for liquid propulsion rocket engine testing by both the Department of Defense and NASA for the manned-space program. The portion of the site that is of interest in this study, Area IV, was designated for energy research in 1954 by North American Aviation's Atomics International (AI). A 90-acre subarea of Area IV was leased to the Atomic Energy Commission and then to DOE for other research including nuclear energy. This 90 -acre subarea came to be known as the Energy Technology Engineering Center (ETEC).

Several chemicals were used to support the research conducted at Area IV, including PCBs in electrical components and hydraulic fluids, fuels to run auxiliary generators and heat water for steam, solvents to clean components, metals such as

mercury for energy transfer applications, and silver for photograph development. Waste from transformers, storage tanks, drums in storage areas, and leach fields was combusted onsite which released PCBs, metals, fuels and lubricants, and solvents. These combustion activities and the 2005 Topanga Wildfire also resulted in the generation of dioxins and furans.

The DOE led some of the research conducted in Area IV, and they are now responsible for addressing soil and groundwater contamination resulting from historic research activities. The most recently published estimate of SSFL soil volume with contaminants at levels exceeding the DTSC's Look Up Table (LUT) values is approximately 1,070,220 cubic yards (Collins, Sherwin, and Hambrick 2013). 
This bioremediation study was performed in conjunction with natural attenuation, phytoremediation, soil partitioning, and mercury volatilization studies to determine the course of action to best minimize the amount of contaminated requiring excavation and transport to proper disposal. Eventually, DOE would like to turn this site into a park. Although there are several types of contaminants at the site, those addressed in this study include PAHs, PCBs, petroleum hydrocarbons, and dioxins. Groundwater contamination was not addressed in this study.

\subsection{Site Contamination Characterization}

Extensive site assessment indicates that contaminant concentrations in soil span a wide range (Table 1).

Table 1: Historic Area IV contaminant concentrations vary widely across the site.

\begin{tabular}{clll}
\hline Contaminant Type & Contaminant & Low Concentration & High Concentration \\
\hline & Heavy lube oil & 170 & 82,000 \\
\cline { 2 - 4 } & $\begin{array}{l}\text { Diesel (31-40 } \\
\text { carbons) }\end{array}$ & 5.9 & 5,100 \\
\cline { 2 - 4 } TPH (ppm) & $\begin{array}{l}\text { Diesel (20-30 } \\
\text { carbons) }\end{array}$ & 31 & 1,300 \\
\cline { 2 - 4 } & Gasoline & 3 & 6.6 \\
\cline { 2 - 4 } & $\begin{array}{l}\text { Kerosene (15-20 } \\
\text { carbons) }\end{array}$ & 0.44 & 350 \\
\hline SVOC/PAH (ppb) & SVOC/PAH & 6.3 & 351,600 \\
\hline Dioxins & Dioxins & 2.68 & 650 \\
\hline TCDD TEQ, ppt) & Aroclor 1242 & 392 & $24,000,000$ \\
\cline { 2 - 4 } PCBs (ppb) & Aroclor 1248 & 34 & 49,100 \\
\cline { 2 - 4 } & Aroclor 1254 & 19 & 49,000 \\
\cline { 2 - 4 } & Aroclor 1260 & 4.2 & \\
\hline
\end{tabular}

There are significantly higher concentrations of longer equivalent carbon chain hydrocarbons than their shorter counterparts (Table 1). This indicates that lighter hydrocarbons have mostly degraded (a preferential substrate to microorganisms). The longer equivalent carbon chain hydrocarbons that are left behind are highly weathered 
and likely bound to soil particles, reducing their bioavailability (Smith et al. 2007).

Most of the site's PAH contamination is comprised of compounds with 4-6 aromatic rings (Appendix C, Bar Graphs of Individual PAH Compounds in Soils A, B, and $\mathrm{C}$, illustrates this point). This fact agrees with the majority of papers cited in literature which indicate that PAH degradability becomes more difficult as the number of aromatic rings increases.

PCB contamination consists primarily of heavily chlorinated Aroclor mixtures (Aroclors 1254, 1260, and 5460). These Aroclors are 54\%, 60\%, and 59\% chlorine by weight, respectively. These heavily chlorinated PCB mixtures' dominant presence at the site compared to their lighter chlorinated counterparts and the site's aerobic soil gas data support the well-cited literature hypothesis that more heavily chlorinated PCBs require anaerobic conditions to degrade to lighter-chlorinated compounds. Initial site data indicates that lesser-chlorinated PCBs either were not used at the site or have been aerobically degraded (Appendix D, Bar Graphs of Aroclor Concentrations in Soils A, B, and C), and more heavily chlorinated PCBs remain in soil because of the aerobic conditions. It is unlikely that the site will achieve anaerobic conditions because of the low rainfall in Simi Valley (13.8 inches) (Simi Valley, CA Weather) and the soil characteristics. In addition, groundwater at the site is being pumped and treated, eliminating the potential for saturated conditions.

The majority of contamination at the site is composed of the octachlorodibenzodioxin (OCDD) congener, which is the most heavily chlorinated dioxin. The next most common dioxin is 1,2,3,4,6,7,8 heptachlorodibenzo-p-dioxin (HpCDF), but it is present at levels less than $10 \%$ of OCDD concentrations soils used in 
these experiments (Appendix B, Bar Graphs of Individual Dioxin Congeners in Soils A, $\mathrm{B}$, and C). These two compounds have a fairly low toxic equivalent factor (TEF):

OCDD's TEF is 0.0003, and HpCDD's is 0.01 (EPA 2013a). Clearly, individual compounds' TEF and the resulting dioxin toxicity equivalence (TEQ) must be understood when assessing mitigation of site contamination.

\subsection{Contaminants}

\subsubsection{Petroleum Hydrocarbons}

Hydrocarbon contaminants are present in the environment in two main forms: aliphatics and aromatics. Aliphatics may be saturated (alkanes), unsaturated (alkenes and/or alkynes), or may form cyclic ring structures. Hydrocarbons containing one or more aromatic ring structures are referred to as aromatic hydrocarbons; some of these are more readily degraded by indigenous microbes than others (Tyagi, da Fonseca, and de Carvalho 2011). Alkanes are typically quickly degraded, while polycyclic aromatic hydrocarbons are very recalcitrant (Van Hamme, Singh, and Ward 2003). Reported efficiencies of biodegradation for soil fungi and bacteria and marine bacteria vary (Table 2): 
Table 2: Minimum and maximum biodegradation rates reported for soil and marine organisms

\begin{tabular}{ccccc}
\hline Organism type & $\begin{array}{c}\text { Minimum reported } \\
\text { biodegradation (\%) }\end{array}$ & Reference & $\begin{array}{c}\text { Maximum reported } \\
\text { biodegradation (\%) }\end{array}$ & Reference \\
\hline Soil fungi & 6 & $\begin{array}{c}\text { (Jones, } \\
\text { Knight, and } \\
\text { Byron 1970) }\end{array}$ & 82 & $\begin{array}{c}\text { (Pinholt, Struwe, } \\
\text { and Kjoller } \\
\text { 1979) }\end{array}$ \\
\hline Soil bacteria & 0.13 & $\begin{array}{c}\text { (Jones, } \\
\text { Knight, and } \\
\text { Byron 1970) }\end{array}$ & 50 & $\begin{array}{c}\text { (Pinholt, Struwe, } \\
\text { and Kjoller } \\
\text { 1979) }\end{array}$ \\
\hline Marine bacteria & 0.003 & $\begin{array}{c}\text { (Hollaway, } \\
\text { Faw, and } \\
\text { Sizemore } \\
1980)\end{array}$ & $\begin{array}{c}\text { (Mulkins Phillips } \\
\text { and Stewart } \\
1974)\end{array}$ \\
& & 100 & \\
\hline
\end{tabular}

It is clear that reported degradation rates vary widely. In addition, because

hydrocarbon mixtures in soil and water are complex, mixed populations with broad enzymatic capacities are needed for their degradation (Das and Chandran 2010).

Fortunately, several bacteria are known to feed exclusively on hydrocarbons (Yakimov, Timmis, and Golyshin 2007). In particular, Gordonia, Brevibacterium, Aeromicrobiom, Dietzia, Burkholderia, and Mycobacterium were identified as potential organisms for hydrocarbon degradation when isolated from petroleum-contaminated soil (Chaillan, Fleche, and Bury et al. 2004).

Petroleum hydrocarbon degradation rates are dependent on several environmental factors (Brusseau 1998). A compound's structure and biodegradability are two of the most prominent considerations when assessing remedial options (Das and Chandran 2010). Temperature also plays an important role, affecting pollutant chemistry and microbial physiology and diversity (Das and Chandran 2010). Typically, biodegradation rates decrease as temperature decreases (Das and Chandran 2010). Bartha, Bossert, and Cooney (Bartha and Bossert 1984; Cooney 1984) showed that the highest degradation rates occur at $30-40^{\circ} \mathrm{C}$ in soil, $20-30^{\circ} \mathrm{C}$ in some freshwater environments, and $15-20^{\circ} \mathrm{C}$ in marine environments. In addition, nutrient availability (especially nitrogen, phosphorus, 
and even sometimes iron) is essential for hydrocarbon degradation (Cooney 1984). If degradation is nutrient-limited, biodegradation may be impeded. However, excessive nutrients can also be detrimental to degradation (Chaillan et al. 2006). In fact, high NPK levels' detrimental effects on biodegradation are well-cited (Oudot, Merlin, and Pinvidic 1998; Chaineau et al. 2005; Carmichael and Pfaender 1997).

Aerobic conditions offer the most rapid and complete degradation of petroleum

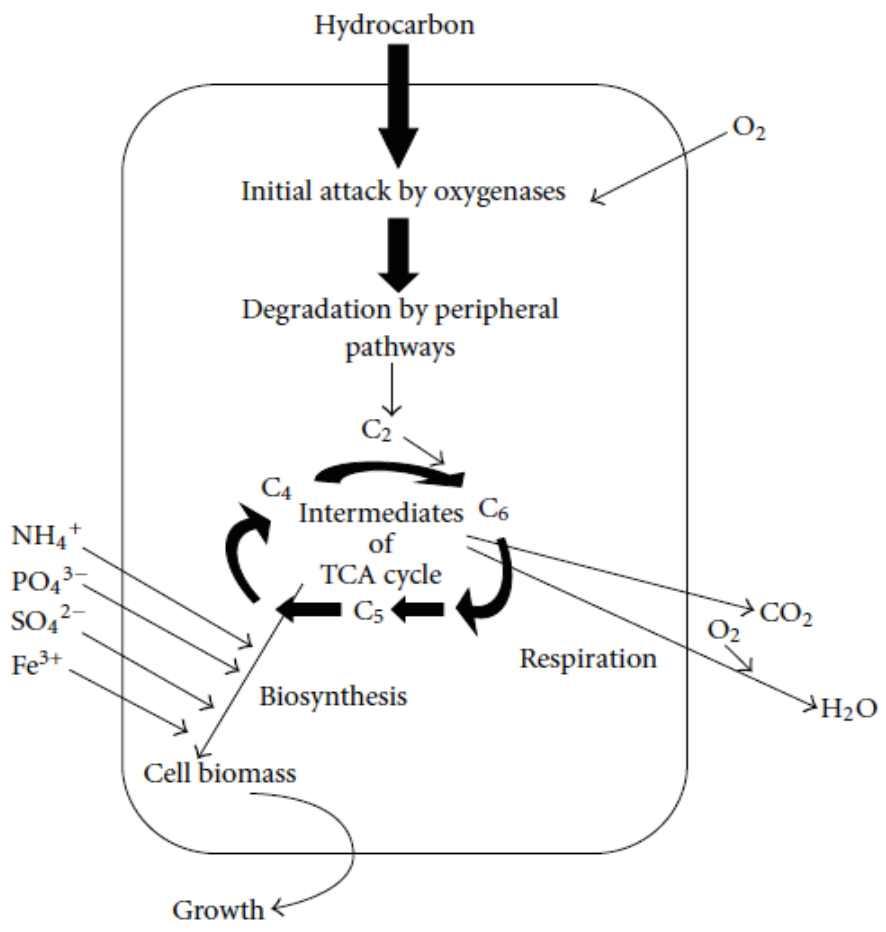

Figure 1: Major hydrocarbon biodegradation pathway (Fritsche and Hofrichter 2000)

hydrocarbons (Das and Chandran 2010). The main mechanism by which hydrocarbons are aerobically degraded is straightforward (Figure 1).

\subsubsection{Polycyclic Aromatic Hydrocarbons}

PAHs are just one class of aromatic hydrocarbons that contain two or more fused aromatic rings arranged in linear, angular, or cluster formations (Cerniglia 1992). In 
general, PAHs are relatively stable, recalcitrant in soils, and notoriously more difficult to degrade than several other organic compounds (Seo, Keum, and Li 2009) They are not easily removed using soil remediation methods that are traditionally used to clean soils contaminated with volatile compounds (Pitter and Chudoba 1990). As the molecular weight of PAHs increases, aqueous solubility and volatility decrease, and PAH recalcitrance increases as a result. There are 16 PAHs identified by the U.S. EPA as priority pollutants, some of which are possible or probable carcinogens (EPA 2013b). According to Ouvrard et al., a contaminant's availability is the primary factor determining its biodegradability (2013). They conducted a 100-month study assessing the capacity of PAHs to naturally attenuate in loamy sand, loam to sandy loam, sandy clay loam, and sandy loam. Soil type used in this study is significant because these soil types are prevalent at the SSFL site. PAH concentrations in soil ranged from $380 \mathrm{mg} / \mathrm{kg}$ to $2,077 \mathrm{mg} / \mathrm{kg}$, and contamination at the site was predominantly 3 and 4 aromatic-ringed compounds typical of weathered contamination from coke origin. Study findings indicate that natural attenuation can be used to remediate PAH-contaminated soils while increasing or preserving soil fertility and biological functions. This suggests that SSFL's soils may be amenable using natural attenuation.

Another factor worth considering when assessing contaminant biodegradability is soil organic carbon content. In fact, PAH compounds' fate and transport in the environment is largely limited by their tendency to sorb to organic carbon. Dissolved organic carbon and water PAH concentrations appeared to be the most relevant factors in PAH degradation rates in one study (Ouvrard et al. 2013). This is likely because the organic composition of soils at a site may act as a long-term PAH sink (Doick and 
Semple 2004). Soil organic carbon content should be considered when assessing PAH transport and degradation in the environment.

PAHs are degraded by at least two mechanisms: one uses the cytochrome P-450 system, and the other uses soluble extra-cellular lignin catabolism enzymes (Yadav, Doddapaneni, and Subramanian 2006). These enzymes include lignin peroxidase, manganese peroxidase (Steffen 2003), and laccase (Andreoni et al. 2004). Cometabolism is essential for biodegradation of some high-molecular-weight PAHs that are not used as a sole carbon or energy source. For example, benzo $[a]$ pyrene is mineralized by microbial cultures when pyrene, oil, or oil fractions are used as a co-substrate (Baboshin and Golovleva 2012). In addition, a study conducted by Hwang and Cutright indicated pyrene biodegradation was enhanced due to cometabolism in the presence of phenanthrene (Sangchul Hwang and Cutright 2004). In 2001, Yuan et al. also found that phenanthrene enhanced the biodegradation of anthracene, fluorine, and pyrene (Yuan et al. 2001). Boldrin et al. reported that fluorine, a compound that could not be used as a sole carbon source, was cometabolically degraded with other PAHs present as growth substrates (Boldrin, Tiehm, and Fritzsche 1993).

Unlike eukaryotes, bacteria can utilize PAHs as a sole carbon and energy source (Johnsen, Wick, and Harms 2005). Typically, aerobic bacterial systems facilitate dioxegynase-catalyzed oxidation of arenes. Early byproducts created by a multicomponent enzyme system include vicinal cis-dihydrodiols that are cleaved by intra or extradiol ring-cleaving dioxygenases through either an ortho- or meta-cleavage pathway. Central intermediates include protocatechuates and catechols, and they are 
converted to tricarboxylic acid cycle intermediates (Cerniglia 1992; Eaton and Chapman 1992; Gibson and Parales 2000).

\subsubsection{Polychlorinated Biphenyls}

The term PCBs encompasses 209 possible PCB congeners with anywhere from 2-10 chlorine atoms bonded to a biphenyl molecule (Center for Disease Control). PCBs were historically manufactured to be inert, stable, flame-resistant, and oxidation-resistant products and used as coolants and dielectric fluids in electrical equipment. They are hydrophobic and partition to organic particles in the environment. Because of these properties, currents and wind can carry PCBs long distances from their original sources. PCBs' chemical properties made them useful in the electrical industry, but their stability also made them compounds termed persistent organic pollutants by the Environmental Protection Agency (Environmental Protection Agency 2014). They were manufactured and sold as Aroclor mixtures primarily by Monsanto Corporation from 1933 to 1977. Aroclor mixtures are identified by a 4-digit numbering code: the first two digits indicate the mixture type, and the last two digits indicate the approximate chlorine content by weight percent. They were banned in the United States in 1979 and globally in 2001 as their environmental and health effects were better understood (Center for Disease Control).

Because of their significant health risk, cost-effective and sustainable methods of in-situ PCBs remediation have long been sought after (Fagervold et al. 2011). Highly chlorinated PCBs like those in Aroclors resist aerobic degradation and must first be partially dechlorinated by anaerobic microbes (Kjellerup et al. 2012). 


\subsubsection{Reductive Dechlorination}

Anaerobic dechlorination was first observed as a change in congener patterns downstream of a capacitor plant that released Aroclor 1242 into the Hudson River (Kjellerup et al. 2012). Since then, it has been shown to occur in the environment before aerobic degradation of lesser chlorinated PCB congeners (Waller et al. 2005). During reductive dechlorination, preferential removal of chlorines proceeds from para to meta to ortho position (Tiedje et al. 1993). Over time, this order of preferential degradation leaves a larger proportion of PCBs with chlorines in the ortho position. Anaerobic Dehalococcoides bacteria have been shown to degrade heavily chlorinated Aroclor 1260; in fact, one study found that the Dehalococcoides population nearly doubled in magnitude its presence (Bedard, Ritalahti, and Loffler 2007). Unfortunately, it is unlinkely that Dehalococcoides populations do or will ever thrive in SSFL soils under current conditions. Results from two soil gas sampling events suggest that the site is aerobic which would prevent proliferation of anaerobic microbes.

\subsubsection{Aerobic Oxidative Processes}

After anaerobic dechlorination, aerobic degradation of lightly chlorinated PCB occurs. During this process, PCBs are converted to chlorobenzoic acids. Indigenous bacteria can degrade the chlorobenzoic acids, producing carbon dioxide, water, chloride, and biomass (Field and Sierra-Alvarez 2008b).

\subsubsection{Combining Anaerobic and Aerobic Processes}

Some studies have explored the coupling of anaerobic and aerobic PCB dechlorination to accelerate PCB degradation. One such study indicated that a PCBcontaminated sediment in an anaerobic PCB dehalorespiring enrichment that was 
transferred into an aerobic culture containing Burkholderia xenovorans LB400

effectively degraded Aroclors by as much as 70\% (Payne, May, and Sowers 2011). In theory, alternating between anaerobic and aerobic conditions to achieve complete PCB dechlorination is ideal, but all anaerobic-aerobic studies have been conducted in closed microcosms that do not accurately represent in-situ conditions (Kjellerup et al. 2012). Soil gas data presented in the Results section 4.1.1 (Site Conditions, Soil Gas Composition) indicates that SSFL is overwhelmingly aerobic and is unlikely to resemble these fluctuating conditions.

\subsubsection{Dioxins}

Dioxins are introduced to the environment by both natural and industrial processes (i.e. forest fires, waste incineration, and chlorinated phenol production). Chlorinated dioxins are naturally formed through catalysis of the coupling of chlorophenols into dioxins by enzymes such as peroxidase (Oberg and Rappe 1992; Wittsiepe et al. 2000). The term 'chlorinated dioxins' encompasses two families of tricyclic, planar, aromatic compounds. One family is comprised of 75 congeners and is referred to as polychlorinated dibenzo-p-dioxins (PCDD), and the other, polychlorinated dibenzofurans (PCDF), is comprised of 135 congeners. PCDD/Fs are stable, have low volatility, are very hydrophobic, and their low bioavailability is the main reason they persist in the environment. They are quite prone to adsorption onto soils and sediments and bioaccumulation in organisms (Field and Sierra-Alvarez 2008a).

Toxicity of dioxin congeners varies. Those with chlorine atoms in the 2, 3, 7, and 8 positions, such as 2, 3, 7, 8-tetrachlorodibenzo-p-dioxin (2378-TeCDD), are highly toxic to mammals and other organisms (Landers and Bunce 1991; Pohjanvirta and 
Tuomisto 1994; Boening 1998). Because only isomers with chlorine groups in the 2, 3, 7 , 8 positions are considered toxic to higher organisms, only 17 PCDDs and 10 PCDFs are toxicologically significant (Field and Sierra-Alvarez 2008a).

Studies have produced conflicting results regarding dioxins' biodegradation in soil. The overwhelming consensus is that biodegradation is most often successful for monochloro- or dichloro-congeners which collectively account for $84 \%$ of the reported cases of aerobic bacterial chlorinated dioxin degradation (Field and Sierra-Alvarez 2008a). Another microcosm study reported 37-44\% reduction of 2,3,7,8-TeCDD when at initial concentrations ranging from 1-100 ppm (Kearney, Woolson, and Ellingto 1972). On a more pessimistic note, one 260-day study indicated no dioxin degradation in soil (Wilson et al. 1997).

In aerobic environments, microbes can aerobically metabolize dioxin by cleaving its aromatic rings. Non-chlorinated and monochlorinated dibenzofurans and dibenzo-pdioxins can serve as the sole carbon and energy sources for some aerobic bacteria that can completely mineralize the non-chlorinated aryl ring (Wilkes et al. 1996).

Pseudomonas and Sphingomonas have been shown to be the most efficient PCDD oxidizers (Field and Sierra-Alvarez 2008a).

In contrast, di- to tetra-chlorinated congeners are attacked co-metabolically during growth of bacteria on another utilizable substrate. Often, this cometabolism results in accumulation of salicyclic acid or chlorocatechols as intermediates (Habe et al. 2001; Hong et al. 2002). This accumulation can be avoided if the compounds are converted through co-cultivation with a chlorosalicylate-degrading bacteria such as Burkholderia 
that can degrade the chlorosalicylate excreted by known PCDD/F degraders (Arfmann, Timmis, and Wittich 1997).

Unfortunately, not all dioxins are accessible by bacteria. PCDD/F congeners with greater than five chlorine atoms are most often inaccessible by aerobic bacteria (Urbaniak 2013). This may be due to several factors including low bioavailability, steric hindrance of angular and ring-cleaving dioxygenase by multiple chlorine substituents, and limited active catalytic site space (Wilkes et al. 1996).

Although no single organism has yet to be identified as capable of degrading all dioxins, Fagervold et al. (2011) hypothesized that collaborated actions of different aerobic microbial groups like fungi and bacterial communities that partake in angular hydroxylation and degrade chlorinated monoaromatic compounds can ultimately break down highly chlorinated dioxins. This publication also stated that anaerobic reductive dehalogenation is the only known biological process able to convert PCDD/Fs and speculated that anaerobic bacteria can remove halogen atoms from di- to octachlorinated PCDD/Fs through co-metabolic bacterial activity with unspecific enzymes.

Dehalorespiration, is one process in which PCDD/Fs can serve as a terminal electron acceptor.

\subsubsection{Reductive Dechlorination}

Highly chlorinated dioxins can be microbially degraded through anaerobic reductive dechlorination (Johnson et al. 2008). During anaerobic reductive dechlorination, a chlorine atom is removed and replaced with a hydrogen atom. Dehalococcoides save energy during dechlorination by using chlorinated compounds as terminal electron acceptors. The rate of dechlorination depends on the degree of 
chlorination; as the number of chlorines increases, the dechlorination rate decreases. Complete dechlorination by bacteria has yet to be observed (Johnson et al. 2008).

\subsubsection{Angular Dioxygenation}

Once dibenzo-p-dioxin and dibenzofuran are dechlorinated, they may be degraded aerobically via angular dioxygenation (Johnson et al. 2008). Angular dioxygenase catalyzes dibenzo-p-dioxin and dibenzofuran degradation by oxidizing one oxygenbonded carbon and its adjacent carbon. Dibenzofuran and dibenzo-p-dioxin are spontaneously converted to 2,2',3-Trihydroxybiphenyl and 2,2',3-Trihydroxydiphenyl ether, respectively (Nojiri, Habe, and Omori 2001). Dibenzofurans are then cleaved at the meta position and converted to salicylic acid or 2-Hydroxypenta-2,4-dienoic acid via hydrolysis. For dibenzo-p-dioxins, angular dioxygenation may be followed by either meta or ortho cleavage followed by spontaneous conversion to either a catechol or 2pyrone-6-carboxylate (Nojiri, Habe, and Omori 2001). If degradation proceeds to completion, compounds react with one or more enzymes, are eventually metabolized by aerobic respiration, and produce cell biomass, carbon dioxide, and water.

\subsection{Bioremediation Technologies}

\subsubsection{Monitored Natural Attenuation}

Monitored natural attenuation (MNA) is used to monitor or test the progress of natural attenuation processes that can degrade contaminants in soil and groundwater. It is useful if degradation rates are fast enough to protect both human health and the environment (US EPA 2013). 
In some cases, natural attenuation is as effective as more complex bioremediation technologies. Couto et al. conducted a study in 2010 that showed natural attenuation was as efficient as bioaugmentation, surfactant addition, and nutrient supplementation at remediating turbine oil-contaminated soils (Couto, Monteiro, and Vasconcelos 2010). Soil aeration did not have a significant effect on biodegradation rates either. Couto et al. contributed this to the fact that the petroleum hydrocarbon contamination was old, and native microorganisms were able to efficiently degrade the contaminants present. This is promising for SSFL because site contamination is decades old and native microbes may already be able to degrade the contaminants present.

A companion study characterized SSFL's microbial communities consist of significant populations of microbes that can aerobically degrade PHCs (Croyle 2014). No bacteria associated with biodegradation of PAHs, PCBs, and dioxins were detected, but several strains of fungi reported to mediate cometabolic biodegradation of these compounds were identified (Croyle 2014).

\subsubsection{Biostimulation}

The term biostimulation umbrellas several remedial technologies used to enhance biodegradation in the field by supplementing soils with growth substrates/co-substrates. Popular biostimulation agents include bulking agents, nutrient supplementation, halogenated priming compounds (halopriming), and surfactants (Rastegarzadeh, Nelson, and Ririe 2006; Richardson et al. 2012; Harkness et al. 1993; Couto, Monteiro, and Vasconcelos 2010; Krumins et al. 2009; Lawniczak, Marecik, and Chrzanowski 2013; Mukherjee and Das 2010; Mulligan, Yong, and Gibbs 2001; Neu 1996; P. K. S. M. Rahman and Gakpe 2008; Rust and Wildes 2008; Fava et al. 2004; Kobayashi et al. 2012; 
Llado et al. 2013; Providenti et al. 1995; Tiehm et al. 1997a; Soeder et al. 1996;

Rodriguez-Escales et al. 2013; Aronstein and Paterek 1995; Yong-lei et al. 2011;

Viisimaa et al. 2013; Inakollu, Hung, and Shreve 2004; Whang et al. 2009; K. S. M.

Rahman et al. 2002; Gorna et al. 2011).

Addition of bulking agents promotes aeration of soils (Rastegarzadeh, Nelson, and Ririe 2006). One such bulking agent is rice hulls. For example, Rastergarzadeh et al. added rice hulls at 10\% w/w 1:1 mixture of soil:drill cuttings. Unamended soils experienced biodegradation of TPH to $91 \%$ from $24 \%$ degradation without rice hulls 4 months.

Nutrient supplementation can be a very effective stimulation method when biodegradation of contaminants is nutrient-limited. A review of the literature indicated that nutrient supplementation effectively enhances biodegradation of PCBs (lightly chlorinated congeners), petroleum hydrocarbons, and PAHs (Harkness et al. 1993; Couto, Monteiro, and Vasconcelos 2010; Richardson et al. 2012). However, even if a carbon source is readily available, microbial growth may be inhibited by limited microelement availability (Lawniczak, Marecik, and Chrzanowski 2013).

Halopriming, a method by which halogenated compounds are added to soils already contaminated with halogenated compounds, has been shown to improve bioremediation of PCBs. Through addition of pentachloronitrobenzene to PCBcontaminated soils, concentrations of lesser-chlorinated PCB congeners (2-4 chlorines per biphenyl) increased by $20 \pm 1.9 \%$ after 415 days of incubation (Krumins et al. 2009). 


\subsubsection{Bioaugmentation}

Bioaugmentation involves the addition of microorganisms known to biodegrade one or more of the contaminants of concern (COCs) present at a site. Several microorgansims have been cited in the literature as known degraders of compounds at SSFL. More specifically, several species of white-rot fungi have been shown to degrade multiple contaminants found at the site. White-rot fungi are a promising class of fungi that have been shown to degrade the recalcitrant compounds found at SSFL. For example, Takada et al. conducted the first study of its kind in which results indicated that a microorganism, Phanerochaete sordida substantially degraded both tetra- to octachlorodibenzo-p-dioxins (PCDDs) and tetra- to octa-chlorodibenzofurans (PCDFs) (1996). Dechlorination of molecules chlorinated at 2-, 3-, 7-, and 8-positions was significant: tetrachloro and hexachloro PCDDs were degraded at approximately $40 \%$ and $76 \%$, respectively; tetrachloro and hexachloro PCDFs were degraded at $45 \%$ and $70 \%$, respectively. Pleurotus ostreatus, another white-rot fungus, degraded PCBs in a study using wood chip as the primary fungus growth substrate (Zeddel et al.1993). After five weeks, a PCB-congener mixture of primarily tri- and tetra-chlorinated biphenyls at 2500 ppm was degraded more than $95 \%$. Penta- and hexa-chlorobiphenyls were found to be degradable by $50 \%$, and the only congener resistant to degradation was $2,2^{\prime}, 4,2^{\prime}, 5,5^{\prime}-$ hexachlorobiphenyl. Unfortunately, the same study indicated that Phanerochaete chrysosporium was unable to degrade any PCBs except mono- and di-chlorobiphenyl at atmospheric oxygen levels.

Fungi show promise in their abilities to degrade SSFL contaminants, but bacteria have also been shown to degrade PCBs. In-situ treatment of PCB-contaminated soils has 
not been shown to be successful in many studies, but a few promising study indicates that it may be possible through bioaugmentation with dehalogenating organisms. One study concluded that a critical cell mass was required for reductive dechlorination of Aroclor 1260; study authors proposed that low populations of dehalorespiring bacteria might be the root cause of insubstantial PCB degradation in the environment (Bedard, Ritalahti, and Loffler 2007). Another study indicated that bioaugmentation with D. ethenogenes and stimulation with haloprimers pentachloronitrobenzene and tetrachlorobenzene effectively accelerated PCB degradation, while stimulation with electron donors did not (Krumins et al. 2009).

Total penta-chlorinated and higher chlorinated PCBs were reduced by $56 \%$ by mass in open mesocosms containing weathered Aroclor 1260 at 1.3 ppm (Payne, May, and Sowers 2011). This was done through augmentation with D. chlorocoercia DF1. D. chlorocoercia was sustained within the local microflora population within 120 days of initial inoculation, meaning that initial bioaugmentation may lead to self-sustaining a remedial method in the field.

One study indicated that the collaborated use of the bacteria Sphingomonas sp. and Pseudomonas sp. increased degradation rates of PCBs to exceed those of the organisms individually, and degradation of more highly chlorinated PCBs was enhanced (Yong-lei et al. 2011).

Consideration should be taken prior to amending soils with foreign microorganisms, though. One study showed that antagonistic effects were observed for native soil microbiota when PAH-contaminated soils were augmented with non-native white-rot fungi (Llado et al. 2013). 
Bioaugmentation can also be used to accelerate degradation of dioxins in soil. In particular, white-rot fungi have been shown to degrade several low to highly chlorinated dibenzo-p-dioxins (Takada et al. 1996). Takada et al. compared the percent degradation of tetra- to octa-chlorinated dibenzo-p-dioxins and dibenzofurans by glucosesupplemented $P$. chrysosporium and $P$. sordida. Glucose-supplemented $P$. chrysosporium consistently degraded all congeners but $2,3,7,8$, TeCDF more efficiently than $P$. sordida at rates ranging from 27.3 to $64.9 \%$ over 7 days. P. sordida's degradation rates of the same contaminants ranged from 14.2 to $50.4 \%$ in the same time period. $P$. sordida's ability to degrade tetra- and octa-chlorinated dibenzo-p-dioxins was supported by identification of a corresponding metabolite from the contaminants. This is significant for environmental contamination because it typically consists of multiple dioxin congeners. Takada et al. also stated that both $P$. sordida and $P$. chrysosporium showed no structural dependence for PCDD/F degradation and that it may be a freeradical process with little specificity. Degradation by the free-radical process may be more favorable in the presence of the oxygen molecule on PCDD/Fs: unlike the little specificity outlined in Takada et al.'s article outlining PCDD/F degradation, Yadav et al. showed in 1995 that PCB (biphenyl molecules lack the oxygen molecules that dioxins and furans contain) degradation becomes more difficult with increasing number of chlorine substitutions around the biphenyl nucleus.

A review conducted by Habe et al. indicates that $32-100 \%$ of mono- to tri-chlorodibenzodioxins/dibenzofurans (DD/DF) at concentrations of $1-10 \mathrm{ppm}$ in artificially contaminated soils were degraded in one week by bacterial strains added to soils (Habe et 
al. 2001). Actual contaminated soils that were inoculated with dioxin-degrading bacteria resulted in $8.3-10 \%$ removal of dioxins after the same incubation time.

The success of bioaugmentation in degrading petroleum hydrocarbons has also been fairly successful. Although one study indicated that biostimulation was more effective than bioaugmentation (Abdulsalam et al. 2011). Again, bioaugmentation proved the most effective remediation method for diesel-contaminated soil in a study using Rhodococcus sp. EH831 (Lee, Kang, and Cho 2011). In another study, bioaugmentation resulted in biodegradation rates two to four times higher than intrinsic biodegradation rates (Malina and Zawierucha 2007). In this study, application of indigenous bacteria resulted in more efficient degradation than that of an exogenous culture.

Bioaugmentation has produced mixed results for PAH degradation as well. In one study, bioaugmentation increased biodegradation of pyrene and phenanthrene by $68 \%$ and $86 \%$, respectively, in aged soils compared to biostimulation (S. Hwang and Cutright 2002). Another study indicated that native soil microbiota hampered augmented microorganisms' growth in petroleum hydrocarbon and high-molecular weight PAHcontaminated soil (Llado et al. 2013).

\subsubsection{Surfactant Addition}

Surfactants are molecules that can increase bioavailability of hydrophobic and/or recalcitrant compounds that are embedded in the soil matrix. They work by increasing compounds' solubility in the aqueous phase (Lawniczak, Marecik, and Chrzanowski 2013; Inakollu, Hung, and Shreve 2004; Whang et al. 2009). They may also change cell membrane properties and increase microbial adherence, increasing the likelihood of 
direct substrate uptake when two immiscible phases are present (Neu 1996; Franzetti et al. 2009). As amphiphilic compounds, surfactants tend to deposit at the oil/water interface (Lawniczak, Marecik, and Chrzanowski 2013). The hydrophobic and lipopholic components of biosurfactant molecules are easily distinguishable and vital to their contribution to bioremediation.

Both synthetic (petrochemical) and natural (oleochemical) surfactant sources are available. Primary petrochemical surfactant feedstocks are crude oil derivatives such as ethylene and benzene. Typical oleochemical surfactant feedstocks are seed oils (palm, soybean, and coconut oils), but plant carbohydrates and animal fats may be used as well. There are four types of surfactants available: anionic, nonionic, cationic, and amphoteric. The largest group, anionic surfactants, has superior wetting and emulsifying properties and tends to be constituted of higher-foaming materials (Rust and Wildes 2008). Nonionic surfactants are known to be the least toxic. Amphoteric surfactants behave as either mild cationic or anionic surfactants depending on pH (Rust and Wildes 2008).

Biosurfactants are known to rival their synthetic counterparts' efficiency while being more biodegradable and less toxic to contaminant-degrading microorganisms (Lawniczak, Marecik, and Chrzanowski 2013). They may either be added to soils externally (most common) or produced on-site. For on-site production, soils must either contain or be augmented with microorganisms capable of biosurfactant production (Lawniczak, Marecik, and Chrzanowski 2013).

Some types of biosurfactants have become more popular than others. For example, rhamnolipids often serve as a model biosurfactant for experiments (Rahman et al. 2002). Use of rhamnolipid surfactants has accelerated degradation of petroleum 
hydrocarbons (Inakollu, Hung, and Shreve 2004). It is important to note that Inakollu et al.'s study indicated that the use of biosurfactants enhanced biodegradation of all hydrocarbons except phenanthrene and naphthalene, perhaps because surfactant solubilization is influenced by contaminant molecular size and structure.

The largest volume of soy-based surfactants is constituted by soy lecithin, an anionic surfactant (Rust and Wildes 2008). It has been shown to improve biodegradation of both PCBs and PAH (Fava et al. 2004; Soeder et al. 1996).

Perhaps the most important considerations to take into account when applying biosurfactants for bioremediation of contaminants include bio-compatibility between the pollutants, microorganisms, and biosurfactants. Native microflora may also impact insitu biosurfactant treatment. Rhamnolipids can sometimes be biodegraded preferentially over contaminants (Chrzanowski et al. 2012). For example, Lin et al. (2011) showed initial enhanced biodegradation diesel oil through addition of biosurfactants, but the biodegradation rate in latter stages of the study was similar to that in the absence of biosurfactants. In this study, hydrocarbon availability was likely the limiting factor in the beginning of the degradation process. Degradation in the later stage was likely limited by desorption and mass transfer of hydrocarbon in the soil matrix (Lin et al. 2011), or they may simply serve as an alternative carbon source (an undesired outcome if metabolized before target contaminants). One way to solve this issue is to apply microorganisms that do not preferentially degrade biosurfactants, a trait commonly observed in biosurfactant producers (Providenti et al. 1995).

Biological and chemical surfactants are very promising remedial amendments for PCB-contaminated soils: addition of biological and chemical surfactants resulted in 47- 
50\% PCB removal in one study (Viisimaa et al. 2013), biosurfactant amendment reduced concentrations of hexa- to nona-chlorinated congeners by $10-20 \%$ in another study (with no significant change in overall PCB concentrations), and the biosurfactant soya lecithin, specifically, resulted in 40\% degradation of all PCBs in one year (Federici et al. 2012).

Literature review yielded no published studies in which biosurfactant was used for remediation of soils contaminated with dioxins.

Surfactants have also been confirmed to enhance mobilization and biodegradation of PAHs in soils (Tiehm et al. 1997b). Some nonionic surfactants were able to enhance degradation of naphthalene and phenanthrene as observed by Aronstein et al (1991).

Before surfactants are applied in the field, several factors must be considered: cost, effectiveness at low concentrations (generally less than 3\%), low toxicity, low adsorption to soil, low soil dispersion, and low surface tension. All of these factors shold be considered prior to surfactant selection (Mulligan, Yong, and Gibbs 2001).

\subsubsection{Combined Treatments}

Biostimulation and bioaugmentation can be combined with each other and other technologies to successfully accelerate contaminant degradation even more than for one treatment alone. For example, one study assessed both bioaugmentation and biostimulation (with 1,2,3,4-tetrachlorobenzene and 2',3',4'-trichloroacetophenone) to accelerate dechlorination of PCDDs (Bedard, Ritalahti, and Loffler 2007). Using denaturing gradient gel electrophoresis, this study found that sites with more contamination were associated with more indigenous dechlorinators. Interestingly, biostimulation and bioaugmentation did not greatly enhance dechlorination at heavily contaminated sites, but it did at less contaminated sites. Another study indicated that the 
combination of biostimulation and bioaugmentation in a silty-loam soil with $60,600 \mathrm{mg}$ $\mathrm{kg}^{-1}$ of a complex mixture of TPH (comprised of $40 \%$ aliphatic hydrocarbons and $21 \%$ PAHs) was more effective than biostimulation alone (Mancera-López et al. 2008). In this study, Rhizopus sp., Penicillium funiculosum and Aspergillus sydowii resulted in 36\%, $30 \%$ and $17 \%$ more PAH compared to biostimulation alone, respectively. Another 120day study indicated that a combined treatment using biostimulation, biosurfactant, and bioaugmentation resulted in the highest hydrocarbon degradation rate of the five treatments assessed (biostimulation, biosurfactant addition, bioaugmentation, natural attenuation, and the combined treatment) (Bento et al. 2005). Similar results were obtained in another study where bioaugmentation combined with nutrient and surfactant amendments resulted in 50\% TPH degradation, while natural attenuation resulted in just 30\% TPH degradation (Couto, Monteiro, and Vasconcelos 2010). 


\subsection{METHODS}

\subsection{Soil Sampling Site Selection and Prescreening Soil Collection}

Soils used in the microcosm study were collected from SSFL on January 16, 2014.

To choose soil collection locations, historical COI concentration data was analyzed with the following considerations in mind:

- Soils needed to be contaminated with moderate COI concentrations, meaning contaminant concentrations fell within a range determined using best professional judgment (Table 3):

- Soils needed to have minimal concentrations of metals to prevent potential toxicity to microbes, and

- Ideally, all soil collection sites would be in historic site drainages to maximize soil homogeneity. Two of the three sampling locations were within historic drainages (Drainage East of 4015 Field and $17^{\text {th }}$ Street Pond and Drainage).

Table 3: Total target soil contaminant concentrations

\begin{tabular}{|l|l|}
\hline Contaminant & Total concentration \\
\hline EFH & $44,000 \mathrm{mg} / \mathrm{kg}$ \\
\hline PAHs & $300,000 \mu \mathrm{g} / \mathrm{kg}$ \\
\hline PCBs & $500,000 \mu \mathrm{g} / \mathrm{kg}$ \\
\hline Dioxins & $100,000,000 \mathrm{ng} / \mathrm{kg}$ \\
\hline
\end{tabular}

Once potential soil collection sites were identified, the sites were prescreened for total organic vapors using a calibrated photoionization detector. Background readings were recorded prior to the start of sampling, and additional readings were taken during 
sampling. Collection sites were also prescreened for residual radiation using a MicroR gamma detector and Dual Phosphor Alpha Scintillator (alpha/beta detector). Gamma, alpha, and beta measurements were collected approximately $0.5-1$ inch above the ground surface of the sample area. Measurements were taken for at least one minute. Once sites were determined to be free of radiation, pre-screening soil samples were also collected to ensure that treatability study samples were not taken from soils with COI concentrations exceeding federal or state regulatory levels for hazardous wastes and to compare actual soil concentrations to target concentrations. Soil sample collection was conducted by Hazardous Waste Operations and Emergency Response (HAZWOPER)-certified field personnel per 29 CFR 1910.120. Once soil samples were collected and analyzed, data was analyzed to determine whether or not contaminant concentrations at the selected locations met the aforementioned criteria. Based on analysis of prescreening soil samples, COI concentrations were lower than target values, so other locations were selected for soil collection.

\subsection{Bulk Soil Sample Collection}

During soil collection, $68 \mathrm{~kg}$ of soil was collected from historic sampling sites 5C_DG-516, 5C_DG-755, and PUBS1044. Soils were collected using stainless steel shovels and placed in Teflon-lined 5-gallon buckets for transport to Cal Poly (Figures 2 and 3).

A total of $68 \mathrm{~kg}$ of soil was collected from the following locations (Figure 4):

- $52 \mathrm{~kg}$ were collected from 4-5.5 feet (ft) beneath ground surface (bgs) at 5C_DG516 ("Soil A"),

- $8 \mathrm{~kg}$ were collected from 1-4 ft bgs at PUBS1044 (“Soil B”), and 
- $8 \mathrm{~kg}$ from 1-4 ft bgs at 5C_DG-755 (“Soil C”).

Soil gas data and soil temperature were collected from the site in the summer of 2014. Soil properties including total organic carbon (TOC), total nitrogen, $\mathrm{pH}$, and moisture were also measured and recorded during the first and second microcosm sampling events.

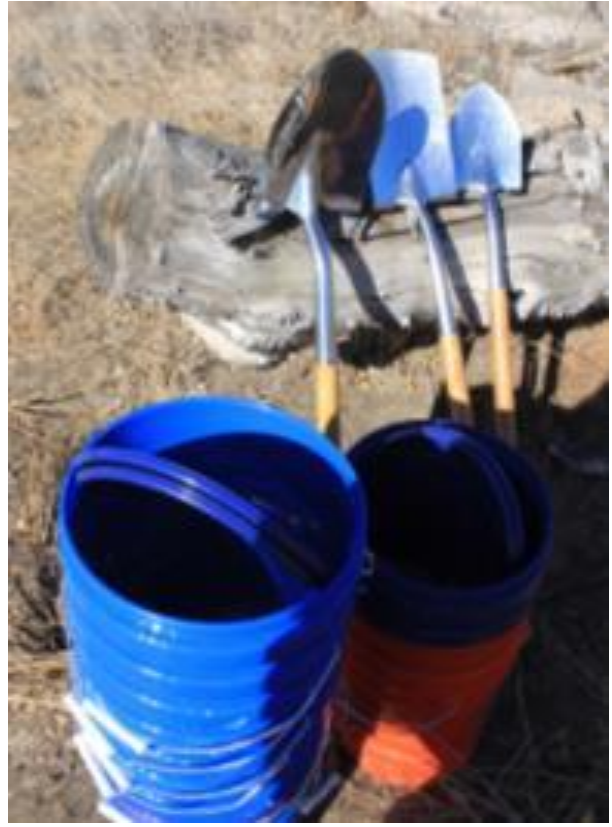

Figure 2: Stainless steel shovels and bulk soil collection buckets (Teflon liners not shown)

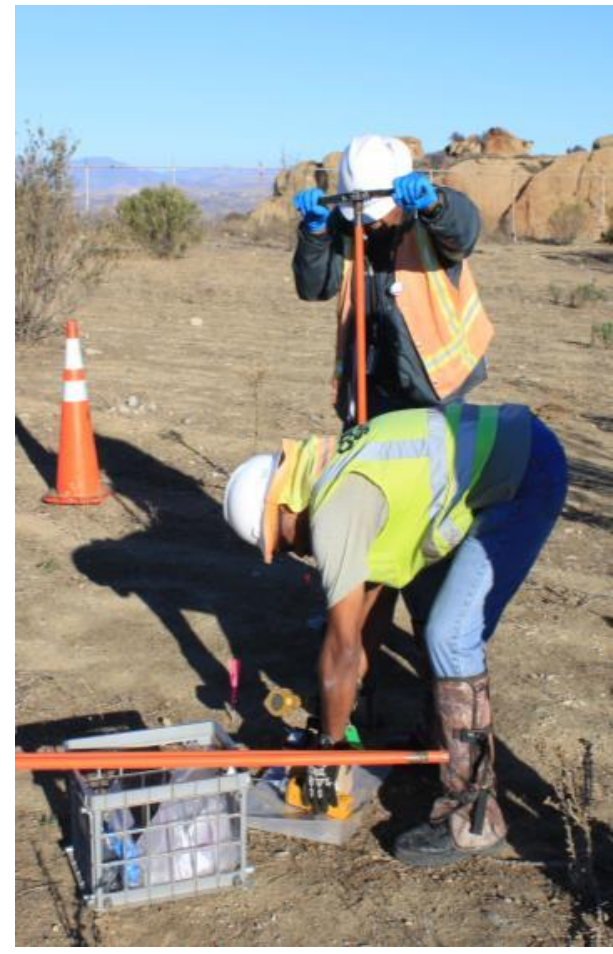

Figure 3: Organic vapor and radiation levels were monitored throughout sample collection 


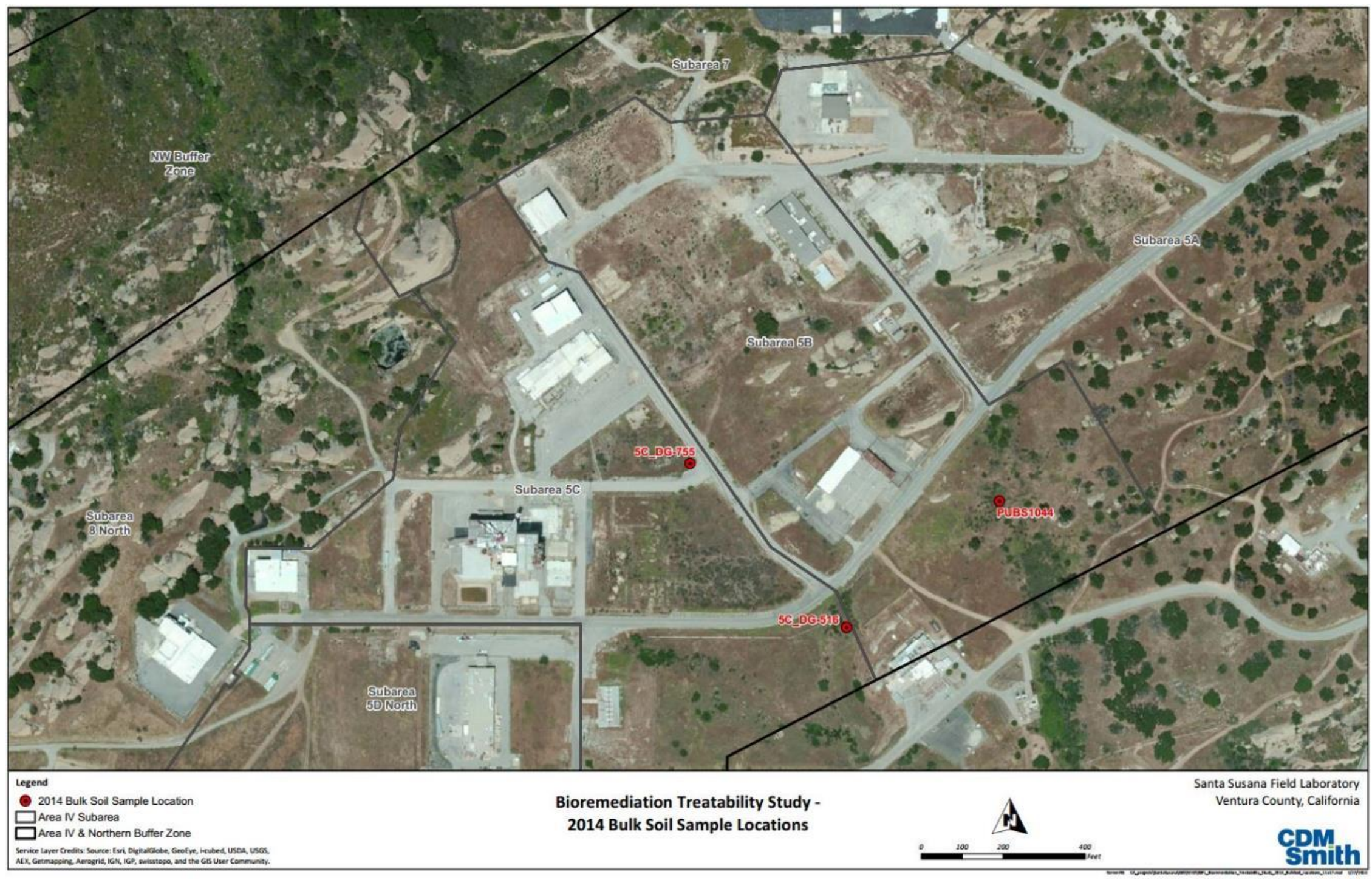

Figure 4: Bulk Soil Sample Collection Locations 


\subsection{Soil Processing}

Soils collected from the aforementioned locations were sieved through a No. 4 sieve (4.76 mm) (Figure 5). After sieving, soil was homogenized in 5-gallon increments in an acid-washed (10\% weight by weight, w/w, $\mathrm{HNO}_{3}$ solution followed by triple-rinsing with DI water) 10-gallon UNS S30400 stainless steel drum. Soils were rolled in a well-ventilated area for

five minutes and replaced in their

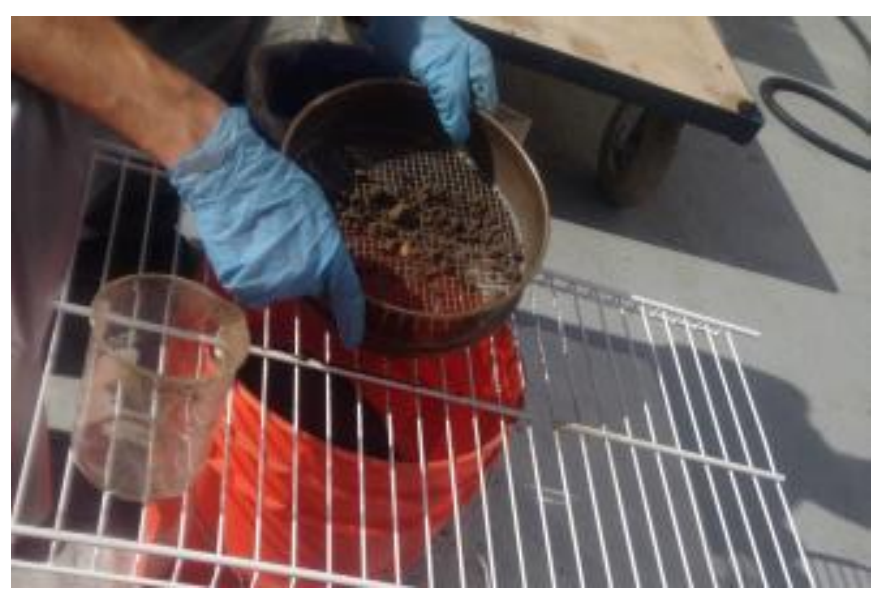

Figure 5: Soil sieving

respective Teflon-lined 5-gallon

buckets. The drum was rinsed and air-dried between uses.

After sieving and homogenization, soil moisture of soils from all three sampling sites was determined using ASTM International Method D2216 (ASTM Standard D2216, "Standard Test Methods for Laboratory Determination of Water (Moisture) Content of Soil and Rock by Mass” 2010). Soil samples were placed in a clean, dry, labeled container. A balance was used to determine the mass of the moist soil and container. This value was recorded. The moist soil was then placed in a drying oven at $105^{\circ}$ overnight. Once dry, the soil was removed from the oven and reweighed using the same balance. This oven-dried mass was recorded and used to determine the water content of the sample. Water content was used to determine the amount of water required to amend soils to $15 \% \mathrm{w} / \mathrm{w}$ water content. 


\subsection{Microcosm Preparation}

In total, 45 4-L Fisher Scientific ${ }^{\mathrm{TM}}$ glass jars and the Teflon ${ }^{\mathrm{TM}}-$ lined lids to be used in the experiment were acid washed in a $10 \% \mathrm{w} / \mathrm{w}$ nitric acid solution composed of nitric acid and milli-Q water. The 45 jars and lids were then triple rinsed in milliQ water and air dried.

Following soil homogenization (outlined above), 1.4 kilograms (kg) of soil was placed in each 4-L acid-washed glass jar. Amendments were added to microcosms as described in Table 4 and thoroughly mixed using a stainless steel spatula.

Amendments were added to each microcosm as shown in Table 3, and the moisture content was adjusted to $15 \%$. Based on results of soil moisture testing, moisture content was adjusted to the desired water content of $15 \%$ w/w. After moisture and amendments were added to each microcosm, they were thoroughly mixed with a stainless steel trowel, sealed with a Teflon-lined lid, and shaken to evenly distribute soil.

Five of the microcosms containing soil from collection location 5C_DG-516 and milliQ water (for $15 \%$ moisture) were transported to Sterigenics, a sterilization facility, located in Gilroy, California. Microcosms were dosed with 25 kilograys using Cobalt-60 irradiation to ensure adequate sterilization (Abo-El-Seoud et al. 2004). 
Table 4: Microcosm soil locations and sampling frequency (5 replicates per Microcosm ID)

\begin{tabular}{|c|c|c|c|c|c|c|c|}
\hline $\begin{array}{l}\text { Microcosm } \\
\text { ID }\end{array}$ & Description & Amendments & Abbreviation & $\begin{array}{c}\text { Amount Amendment } \\
\text { Added }\end{array}$ & Sterile? & $\begin{array}{l}\text { Collection } \\
\text { Location }\end{array}$ & $\begin{array}{l}\text { Sampling } \\
\text { Times }\end{array}$ \\
\hline A1 & Fertilized & Nutrient solution & NUTRIENT & $\begin{array}{c}0.1 \mathrm{~g} \mathrm{KH}_{2} \mathrm{PO}_{4} \\
0.015 \mathrm{~g} \mathrm{MgSO}_{4} \cdot 7 \mathrm{H} 2 \mathrm{O} \\
0.02 \mathrm{~g} \mathrm{CaCl}_{2} \cdot 2 \mathrm{H}_{2} \mathrm{O} \\
0.29 \mathrm{~g} \mathrm{NaNO}_{3}\end{array}$ & No & 5C_DG-516 & $0,4,8$ mos. \\
\hline $\mathrm{A} 2$ & Surfactant & Soya lecithin & SURFACT & $1.5 \% \mathrm{w} / \mathrm{w}$ & No & 5C_DG-516 & $0,4,8$ mos. \\
\hline A3 & Bulking agent & Rice hulls & RICEHULL & $10 \% \mathrm{w} / \mathrm{w}$ & No & 5C_DG-516 & $0,4,8$ mos. \\
\hline A4 & Bioaugmented & $\begin{array}{l}\text { Rice hulls, } \\
\text { Nutrient solution, } \\
\text { Malt extract, } \\
\text { P. chrysosporium }\end{array}$ & BIOAUGM & $\begin{array}{c}10 \% \text { w/w rice hulls } \\
0.1 \mathrm{~g} \mathrm{KH}_{2} \mathrm{PO}_{4} \\
0.015 \mathrm{~g} \mathrm{MgSO}_{4} \cdot 7 \mathrm{H} 2 \mathrm{O} \\
0.02 \mathrm{~g} \mathrm{CaCl}_{2} \cdot 2 \mathrm{H}_{2} \mathrm{O} \\
0.29 \mathrm{~g} \mathrm{NaNO}_{3} \\
0.15 \mathrm{~g} \mathrm{malt} \mathrm{extract} \\
\text { P. chrysosporium }\end{array}$ & No & 5C_DG-516 & $0,4,8$ mos. \\
\hline A5 & $\begin{array}{l}\text { Combined } \\
\text { Amendments }\end{array}$ & $\begin{array}{c}\text { Rice hulls, } \\
\text { Nutrient solution, } \\
\text { Malt extract, } \\
P . \text { chrysosporium, } \\
\text { Soya lecithin }\end{array}$ & COMB & $\begin{array}{c}10 \% \text { w/w rice hulls } \\
0.1 \mathrm{~g} \mathrm{KH}_{2} \mathrm{PO}_{4} \\
0.015 \mathrm{~g} \mathrm{MgSO}_{4} \cdot 7 \mathrm{H} 2 \mathrm{O} \\
0.02 \mathrm{~g} \mathrm{CaCl}_{2} \cdot 2 \mathrm{H}_{2} \mathrm{O} \\
0.29 \mathrm{~g} \mathrm{NaNO}_{3} \\
0.15 \mathrm{~g} \mathrm{malt} \mathrm{extract} \\
P . \text { chrysosporium } \\
1.5 \% \text { soya lecithin }\end{array}$ & No & 5C_DG-516 & $0,4,8$ mos. \\
\hline A6 & Unamended A & None & UNAMENDA & None & No & 5C_DG-516 & $0,4,8$ mos. \\
\hline A7 & Sterilized & Gamma irradiation & STERILE & $\begin{array}{c}25 \text { kilograys of gamma } \\
\text { irradiation }\end{array}$ & Yes & 5C_DG-516 & 0 and 8 mos. \\
\hline B6 & Unamended B & None & UNAMENDB & None & No & PUBS1044 & $0,4,8$ mos. \\
\hline C6 & Unamended C & None & UNAMENDC & None & No & 5C_DG-755 & $0,4,8$ mos. \\
\hline
\end{tabular}




\subsection{Microcosm Incubation}

Microcosms were incubated in a U-Line stainless steel cabinet lined with polyisocyanurate foam board insulation. Temperature was kept constant in this cabinet using a temperature-controlled water bath with tubing routed throughout the shelving. Microcosm temperature was measured and recorded weekly using a HDE high accuracy non-contact Fluke infrared IR thermometer gun with laser sight. Soil temperature was also measured and recorded directly with a standard thermometer in an extra microcosm that contained no amendments. This temperature reading confirmed that the infrared thermometer's measurements were representative of actual soil temperature.

\subsection{Sample Collection and Analysis}

Samples were collected from each microcosm at experiment startup and 126 and

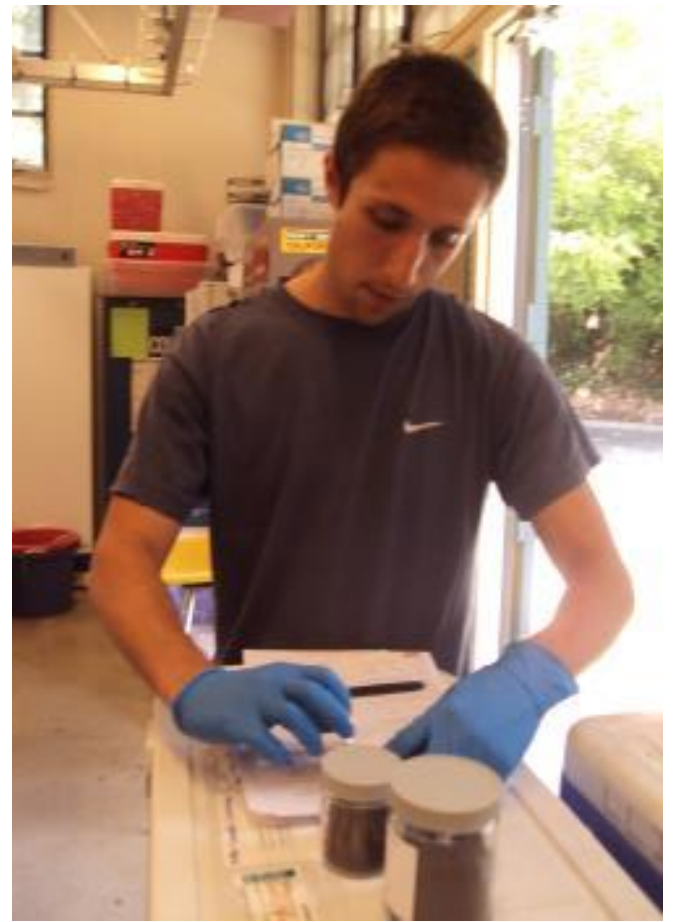

Figure 6: Soil sample processing: labeling and completing the chain of custodv

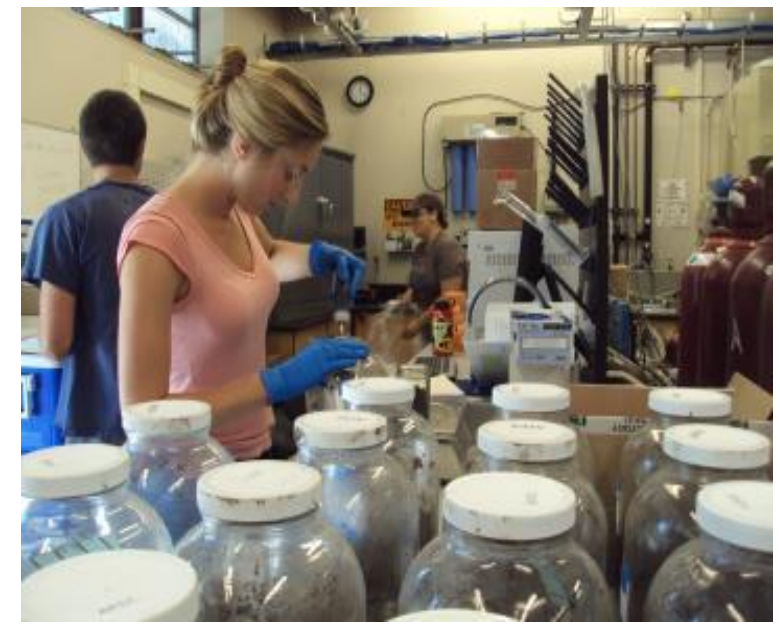

Figure 7: Soil sample collection 
244 days after the start of incubation (Figures 6 and 7). Sampling was conducted using a stainless steel shovel that was washed with Alconox and triple-rinsed with ASTM Type II Water (reagent grade water defined by American Standards for Testing and Measurements that is used in the final rinse of surfaces of contaminated equipment) between microcosm types. Table 3 describes experimental design and sampling frequency. All non-disposable sampling equipment used was decontaminated using a decontamination line that progressed from "dirty" to"clean" (equipment entered the decontamination line as dirty and exited as clean). The line consisted of three buckets: one for scrubbing Alconox solution on the equipment with a stiff bristle brush (to remove particulate matter and surface films), one for rinsing off dirt and Alconox with ASTM Type II Water. Equipment was not set down between decontamination and sample collection. If there was a break in sampling, equipment was decontaminated prior to resuming sampling activities. Any equipment that was not reusable was stored for disposal after all sampling activities were complete. At the end of sampling activities, all laboratory-derived waste was collected, labeled as such, and transported back to SSFL for proper disposal.

Samples were transported to EMAX and Lancaster laboratories for analysis using analytical methods listed in Table 4. 
Table 5: Analytical methods used for soil sample analysis

\begin{tabular}{|c|c|c|}
\hline Analyte & Analytical Methods for Soil & Laboratory (sampling date) \\
\hline \multirow[t]{3}{*}{ PCBs } & EPA Method 8082A Gas & EMAX $(0,126$ days $)$ \\
\hline & Chromatograph/Electron Capture & Lancaster (244 days) \\
\hline & Detector & \\
\hline \multirow[t]{3}{*}{ Dioxins } & EPA Method 1613B Gas & Lancaster $(0,126,244$ days $)$ \\
\hline & Chromatograph/High Resolution & \\
\hline & Mass Spectroscopy & \\
\hline \multirow[t]{3}{*}{ PAHs } & EPA Method 8270C/D SIM Gas & EMAX $(0,126$ days $)$ \\
\hline & Chromatograph/High Resolution & Lancaster (244 days) \\
\hline & Mass Spectroscopy & \\
\hline \multirow[t]{3}{*}{ TPH } & EPA Method 8015B/C/D Gas & EMAX $(0,126$ days $)$ \\
\hline & Chromatograph/Flame Ionization & Lancaster (244 days) \\
\hline & Detector & \\
\hline \multirow[t]{6}{*}{ Metals } & EPA Method 6010C/6020A/7471B & EMAX $(0,126$ days $)$ \\
\hline & Inductively Coupled Plasma-Atomic & \\
\hline & Emission Spectrometry, Inductively & \\
\hline & Coupled Plasma-Mass Spectrometry & \\
\hline & Mercury in Solid or Semisolid Waste & \\
\hline & (Manual Cold-Vapor Technique) & \\
\hline Mercury & $\begin{array}{l}\text { Cold vapor atomic absorption } \\
\text { spectroscopy EPA Method 7471B }\end{array}$ & $\operatorname{EMAX}(0,126$ days $)$ \\
\hline \multirow[t]{5}{*}{ Percent Moisture } & ASTM D2216 & Lancaster $(0,126,244$ days $)$ \\
\hline & Standard Test Methods for & \\
\hline & Laboratory Determination of Water & \\
\hline & (Moisture) Content of Soil and Rock & \\
\hline & by Mass & \\
\hline \multirow[t]{6}{*}{ Nitrogen } & ASTM D5373 & Lancaster $(0,126$ days $)$ \\
\hline & Standard Test Methods for & \\
\hline & Determination of Carbon, Hydrogen & \\
\hline & and Nitrogen in Analysis Samples of & \\
\hline & Coal and Carbon in Analysis & \\
\hline & Samples of Coal and Coke & \\
\hline \multirow[t]{2}{*}{ Organic Carbon } & SM 5310B & Lancaster $(0,126$ days \\
\hline & Total Organic Carbon & \\
\hline
\end{tabular}

3.7 Data Analysis

Following sample collection and soil analysis, the resulting data were checked for quality control by CDM personnel. Statistical analyses were performed using Minitab. Average, standard deviation, and standard error of contaminant concentrations (both 
summations of individual compounds within a contaminant type and individual compounds) were calculated. Any lab data with a "U" qualifier was assumed to be nondetect, and the chemical concentration was assumed to be zero.

\subsection{Statistical Analysis}

Statistical analysis of data included a general linear model with the response variable being either chemical concentration, $\log$ (concentration), or the square root of concentration. The $\log$ (concentration) and square root of concentration were calculated in an attempt to normalize data if fanning of residuals was observed. The general linear model used for this analysis analyzed the statistical significance of treatment's effect on contaminant concentration at the three different sampling events. Residual plots provided a helpful visual representation of data normality. The general linear model was used to compare three different sets of data:

- Effect of treatment on changes in contaminant concentrations in soil A

- Effect of gamma irradiation on changes in contaminant concentrations in soil A (using only beginning and end time points to include gamma irradiated samples were not analyzed at the sampling midpoint), and

- Effect of different soil type (A, B, or C) on changes in contaminant concentrations over time. 


\subsection{RESULTS AND DISCUSSION}

This chapter describes first the site conditions (Section 4.1) and then the results of the microcosm experiments (Section 4.2). Characterization of the soil collected for the microcosms is described in the beginning of Section 4.2 (4.2.1).

\subsection{Site Conditions}

\subsubsection{Soil Gas Composition}

Soil gas data collected in June and July of 2014 indicate that average oxygen concentrations at 1 -foot intervals in soil vapor ranged from $10.1 \%$ to $20.0 \%$, and the lowest average concentration was detected at 20-21 feet below ground surface (bgs) (Table 5; raw data is presented in Appendix L). The fact that oxygen is available as a terminal electron acceptor down to the deepest sampling point (20 ft bgs) indicates that aerobic conditions prevail and it is unlikely that there are any anaerobic subsurface conditions at the test sites. There could however be small anaerobic zones on soil particles, but it is unlikely that conditions are favorable for much reductive dehalogenation of chlorinated compounds present at the site.

The maximum carbon dioxide concentration (6.3\%) was detected at $20 \mathrm{ft}$ bgs. The high carbon dioxide concentrations are an indicator of extensive biological respiration - either of contaminants or natural organic material. 
Table 6: June 2014 Soil Gas Data

\begin{tabular}{|c|c|c|c|c|}
\hline \multirow[b]{2}{*}{$\begin{array}{l}\text { Depth Interval (ft } \\
\text { bgs) }\end{array}$} & \multicolumn{2}{|c|}{ Carbon Dioxide (\%) } & \multicolumn{2}{|c|}{ Oxygen $(\%)$} \\
\hline & Average & $\begin{array}{l}\text { Standard } \\
\text { Deviation } \\
\end{array}$ & Average & $\begin{array}{l}\text { Standard } \\
\text { Deviation } \\
\end{array}$ \\
\hline $5-6$ & 1.8 & 2.4 & 18.3 & 3.5 \\
\hline $6-7$ & 2.0 & 1.5 & 16.9 & 5.0 \\
\hline $7-8$ & 2.1 & 1.4 & 17.4 & 3.9 \\
\hline $8-9$ & 1.5 & 1.4 & 18.4 & 1.2 \\
\hline $9-10$ & 2.9 & 2.5 & 17.2 & 3.3 \\
\hline $10-11$ & 3.0 & 3.2 & 15.5 & 6.2 \\
\hline $11-12$ & 2.5 & 1.7 & 17.5 & 1.6 \\
\hline $12-13$ & 3.2 & 2.2 & 13.9 & 8.1 \\
\hline $13-14$ & 1.2 & 1.6 & 18.4 & 1.5 \\
\hline $14-15^{*}$ & 1.0 & N/A & 15.9 & N/A \\
\hline $15-16$ & 4.0 & 4.5 & 14.5 & 6.9 \\
\hline $16-17^{*}$ & 1.6 & N/A & 19.0 & N/A \\
\hline $17-18^{*}$ & 0.0 & N/A & 20.0 & N/A \\
\hline $18-19$ & 2.4 & 1.1 & 16.6 & 0.1 \\
\hline $19-20 *$ & 4.6 & N/A & 16.2 & N/A \\
\hline $20-21$ & 6.3 & 3.8 & 10.1 & 7.7 \\
\hline
\end{tabular}

\subsubsection{Soil Temperature}

Site soil temperatures were measured in May and June of 2014. Overall average site temperature was $30^{\circ} \mathrm{C}$ with a standard deviation of $7^{\circ} \mathrm{C}$ (Table 6). These temperature data were collected in summer months. Soil temperature varied greatly with vegetative cover because of shading and also follow a logical trend of decreasing temperature with increasing depth.

\subsection{Microcosms}

\subsubsection{Characterization of Soils used for Microcosms}

Soil pH, TOC, total nitrogen, and moisture content were all measured during February and June microcosm sampling events in 2014. Due to budget constraints, these soil parameters were not analyzed during the final sampling event in October. 


\subsubsection{Soil $\mathrm{pH}$}

The $\mathrm{pH}$ of the microcosm soils was within the range of 5.8-7.4 (Table 7 and Figure 8). Two microcosm sets (A2 and A5) had an initial pH outside of the EPA's specified acceptable $\mathrm{pH}$ region for optimal bioremediation (6-8). These two microcosm types included soya lecithin as an amendment which may have caused the reduced $\mathrm{pH}$. This indicates that soy lecithin could have an adverse effect on initial degradation. Over time, though, the $\mathrm{pH}$ in soy lecithin-amended microcosms increased to within the acceptable range (Figure 8). This suggests that soya lecithin was degraded over time; it is likely that it was preferentially degraded before other compounds. 
Table 7: Soil Temperature Data (Summer 2014)

\begin{tabular}{|c|c|c|c|c|}
\hline Location ID & Depth (ft) & Time & Temp (degrees C) & Date \\
\hline STS-18_CB_A & 0 & $8: 15$ & 23 & $6 / 2 / 2014$ \\
\hline STS-06_PG_C & 0 & $8: 28$ & 23 & $6 / 4 / 2014$ \\
\hline STS-01_BE_D & 0 & $8: 47$ & 26 & $6 / 2 / 2014$ \\
\hline STS-04_MF_B & 0 & $9: 33$ & 26 & $6 / 3 / 2014$ \\
\hline STS-17_NM_C & 0 & $9: 45$ & 26 & $6 / 4 / 2014$ \\
\hline STS-02_LS_B & 0 & $10: 22$ & 30 & $6 / 3 / 2014$ \\
\hline STS-04_MF_D & 0 & $10: 55$ & 29 & $6 / 2 / 2014$ \\
\hline STS-01_BE_C & 0 & $11: 35$ & 31 & $6 / 4 / 2014$ \\
\hline STS-23_YS_C & 0 & $12: 50$ & 34 & $6 / 3 / 2014$ \\
\hline STS-06_PG_D & 0 & $13: 40$ & 37 & $6 / 2 / 2014$ \\
\hline Average & & & 29 & \\
\hline \multicolumn{2}{|c|}{ Standard Deviation } & & 5 & \\
\hline STS_35_NG_C & 0.1 & $7: 30$ & 22 & $5 / 28 / 2014$ \\
\hline STS_08_SM_CC & 0.1 & $8: 10$ & 22 & $5 / 29 / 2014$ \\
\hline STS-01_BE_A & 0.1 & $8: 30$ & 23 & $5 / 29 / 2014$ \\
\hline STS_17_NM_BB & 0.1 & $8: 45$ & 24 & $5 / 28 / 2014$ \\
\hline STS-23_YS_D & 0.1 & $8: 50$ & 25 & $5 / 30 / 2014$ \\
\hline STS-18_CB_D & 0.1 & $9: 35$ & 27 & $5 / 30 / 2014$ \\
\hline STS_08_SM_D & 0.1 & $9: 36$ & 35 & $6 / 2 / 2014$ \\
\hline STS_08_SM_BB & 0.1 & 9:50 & 28 & $5 / 28 / 2014$ \\
\hline STS_35_NG_A & 0.1 & $10: 30$ & 26 & $5 / 27 / 2014$ \\
\hline STS-23_YS_A & 0.1 & $10: 50$ & 37 & $5 / 29 / 2014$ \\
\hline STS-02_LS_D & 0.1 & 11:00 & 30 & $5 / 30 / 2014$ \\
\hline STS-17_NM_D & 0.1 & $12: 15$ & 49 & $5 / 30 / 2014$ \\
\hline STS-02_LS_C & 0.1 & $12: 40$ & 35 & $5 / 28 / 2014$ \\
\hline STS_35_NG_B & 0.1 & $13: 30$ & 37 & $5 / 27 / 2014$ \\
\hline STS-06_PG_B & 0.1 & $14: 15$ & 44 & $5 / 29 / 2014$ \\
\hline STS_35_MG_D & 0.1 & $14: 25$ & 36 & $5 / 28 / 2014$ \\
\hline Average & & & 31 & \\
\hline \multicolumn{2}{|c|}{ Standard Deviation } & & 8 & \\
\hline STS-18_CB_A & 1.5 & $8: 15$ & 24 & $6 / 3 / 2014$ \\
\hline STS-01_BE_D & 1.5 & $8: 47$ & 27 & $6 / 2 / 2014$ \\
\hline STS-23_YS_D & 1.5 & $8: 50$ & 30 & $5 / 29 / 2014$ \\
\hline STS-23_YS_A & 1.5 & $10: 50$ & 29 & $5 / 29 / 2014$ \\
\hline STS-04_MF_D & 1.5 & $10: 55$ & 25 & $6 / 2 / 2014$ \\
\hline Average & & & 27 & \\
\hline \multicolumn{2}{|c|}{ Standard Deviation } & & 3 & \\
\hline \multicolumn{2}{|l|}{ Overall Average } & & 30 & \\
\hline \multicolumn{3}{|c|}{ Overall Standard Deviation } & 7 & \\
\hline
\end{tabular}


Table 8: Microcosm Soil pH

\begin{tabular}{|l|c|c|c|c|c|c|}
\hline & \multicolumn{2}{|c|}{ Average } & \multicolumn{2}{c|}{ Standard Deviation } & \multicolumn{2}{c|}{ Standard Error } \\
\hline Microcosm Type & 0 days & 126 days & 0 days & 126 days & 0 days & 126 days \\
\hline nutrient & 6.53 & 6.28 & 0.04 & 0.06 & 0.02 & 0.03 \\
\hline soya lecithin & 5.87 & 6.31 & 0.03 & 0.19 & 0.01 & 0.08 \\
\hline rice hulls & 6.60 & 6.24 & 0.07 & 0.17 & 0.03 & 0.08 \\
\hline $\begin{array}{l}\text { nutrients+ } \\
\text { rice hulls+ } \\
P . \text { chrysosporium }\end{array}$ & 6.44 & 6.35 & 0.06 & 0.18 & 0.03 & 0.08 \\
\hline $\begin{array}{l}\text { nutrients+ } \\
\text { soya lecithin+ } \\
\begin{array}{l}\text { rice hulls+ } \\
P . \text { chrysosporium }\end{array}\end{array}$ & 6.03 & 6.18 & 0.03 & 0.09 & 0.01 & 0.04 \\
\hline $\begin{array}{l}\text { unamended site A } \\
\text { unamended site B }\end{array}$ & 6.64 & 6.30 & 0.03 & 0.02 & 0.01 & 0.01 \\
\hline unamen & 6.68 & 0.03 & 0.05 & 0.01 & 0.02 \\
\hline unamended site C & 7.35 & 7.33 & 0.05 & 0.05 & 0.02 & 0.02 \\
\hline $\begin{array}{l}\text { gamma-irradiated } \\
\text { unamended site A }\end{array}$ & 6.676 & N/A & 0.038471 & N/A & 0.017205 & N/A \\
\hline
\end{tabular}

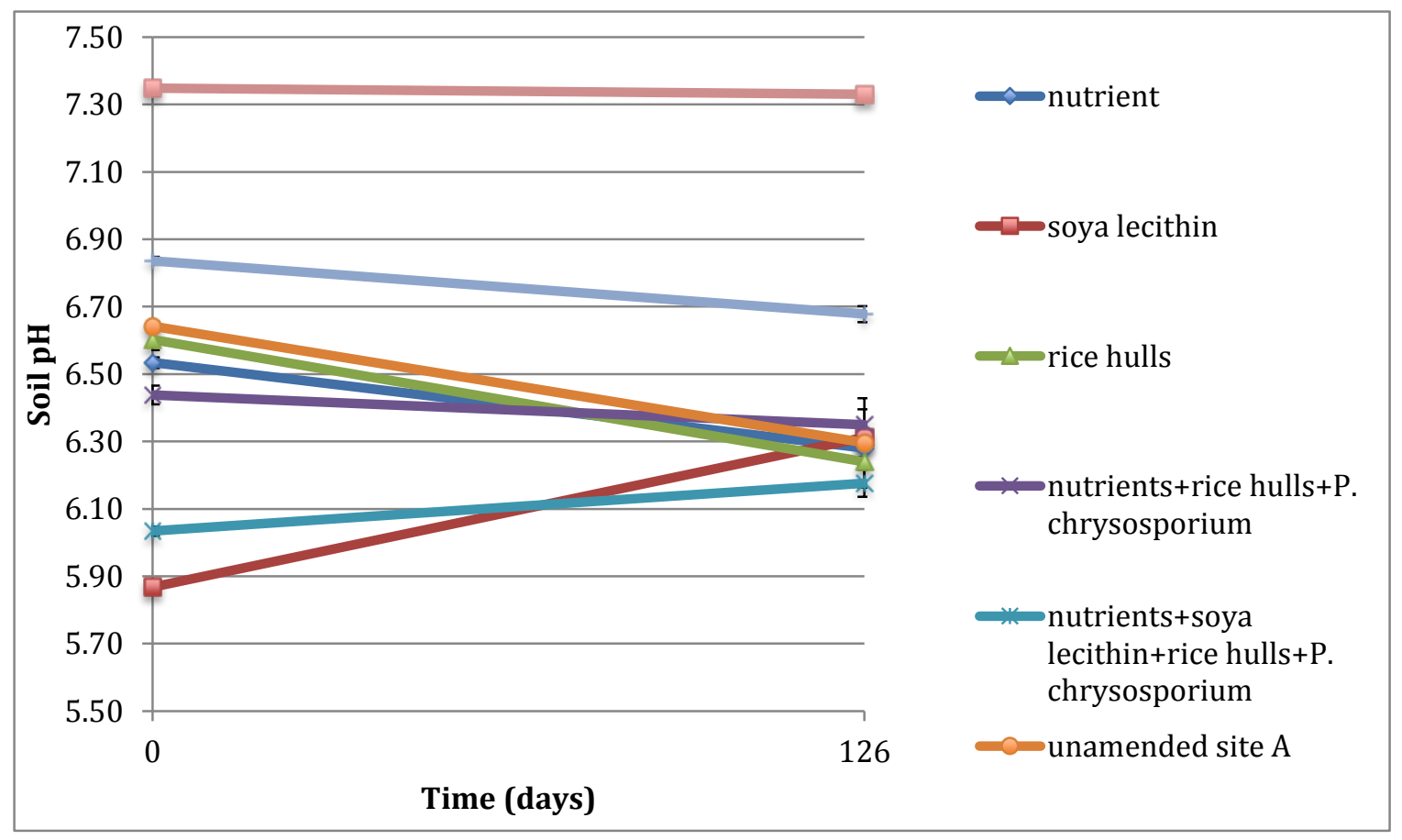

Figure 8: Soil pH in microcosms during incubation 


\subsubsection{Soil TOC}

TOC concentrations in microcosm soils varied for the different microcosm sets (Table 15 and Figure 69, Appendix I). The initial TOC in Site B soils was much greater than that in Site A and Site C soils. TOC decreased slightly in almost all of the microcosms suggesting some biodegradation, but there was a large amount of variability, particularly during the initial sampling event and for both sampling events in the unamended Site B soils.

\subsubsection{Soil Nitrogen}

Total nitrogen concentrations in the microcosm soils varied significantly among microcosm sets (Table 16 and Figure 69, Appendix I). During incubation, nitrogen concentrations eitherremained unchanged or slightly increased. This indicates that there were sufficient nitrogen nutrients in the soil, and contaminant degradation was not nitrogen-limited. Phosphorus concentrations were not measured, so it is not known if phosphate was limiting biodegradation.

\subsubsection{Soil Moisture}

Target experimental soil moisture in the microcosms was $15 \%$ based on previous research (Rastegarzadeh, Nelson, and Ririe 2006). As data from previous sampling events was received and analyzed, soil moisture was adjusted in an attempt to meet the target $15 \%$. As a result, soil moisture was maintained between a minimum of $9 \%$ and a maximum of $17 \%$ throughout the experiment (Table 14, Appendix I). Moisture content can be a limiting factor in biodegradation ("In Situ Biological Treatment"); however, lower moisture content is likely more representative of actual site conditions due to the 
low rainfall at the site and the fact that stormwater is pumped, treated, and removed from the site.

\subsubsection{Soil Contaminant Concentrations}

Before this experiment was started, target soil contaminant concentrations were chosen using professional judgment (Table 3). Soil contaminant concentrations in microcosms were much lower than target concentrations (Appendix K). Total EFH was consistently lower than the target value $(100-230 \mathrm{mg} / \mathrm{kg}$, Appendix K). The cleanup goal for this site is $5.7 \mathrm{mg} / \mathrm{kg}$ of $\mathrm{EFH}(\mathrm{C} 15-\mathrm{C} 20)$, and all unamended microcosm soil concentrations were less than $250 \mathrm{mg} / \mathrm{kg}$. PAH concentrations were also lower than target concentrations (ranging from $87-45,139 \mu \mathrm{g} / \mathrm{kg}$ ). They were very low in Soils A and $\mathrm{C}$, but still above the Look-Up Table value of $4.47 \mu \mathrm{g} / \mathrm{kg}$ TEQ for benzo(a)pyrene. PCB concentrations were lower than target values $(37-328 \mu \mathrm{g} / \mathrm{kg}$ Aroclor 1260) and limited to the most heavily chlorinated mixtures. Heavily chlorinated Aroclors were present at similar levels in all three soils except for Aroclor 5460 in Soil C. Initial dioxin concentrations ranged from $0.026-0.116 \mathrm{mg} / \mathrm{kg}$, which were also lower than the target concentration of $100 \mathrm{mg} / \mathrm{kg}$. Maximum total concentration was observed in Soil A, and minimum total concentration was observed in Soil B. 


\subsubsection{Microcosm Incubation Temperature}

Microcosm soil temperatures throughout the 244 -day study averaged $27.4^{\circ} \mathrm{C}$ with a standard deviation was $3.1^{\circ} \mathrm{C}$ (Figure 9). This is slightly lower than the average site temperature observed in June and July, but presumably much higher than soil temperatures in the winter. This suggests that any biodegradation rates observed in microcosm data could be slightly elevated estimations of what could happen if a bioremediation technology were applied at the site year-round.

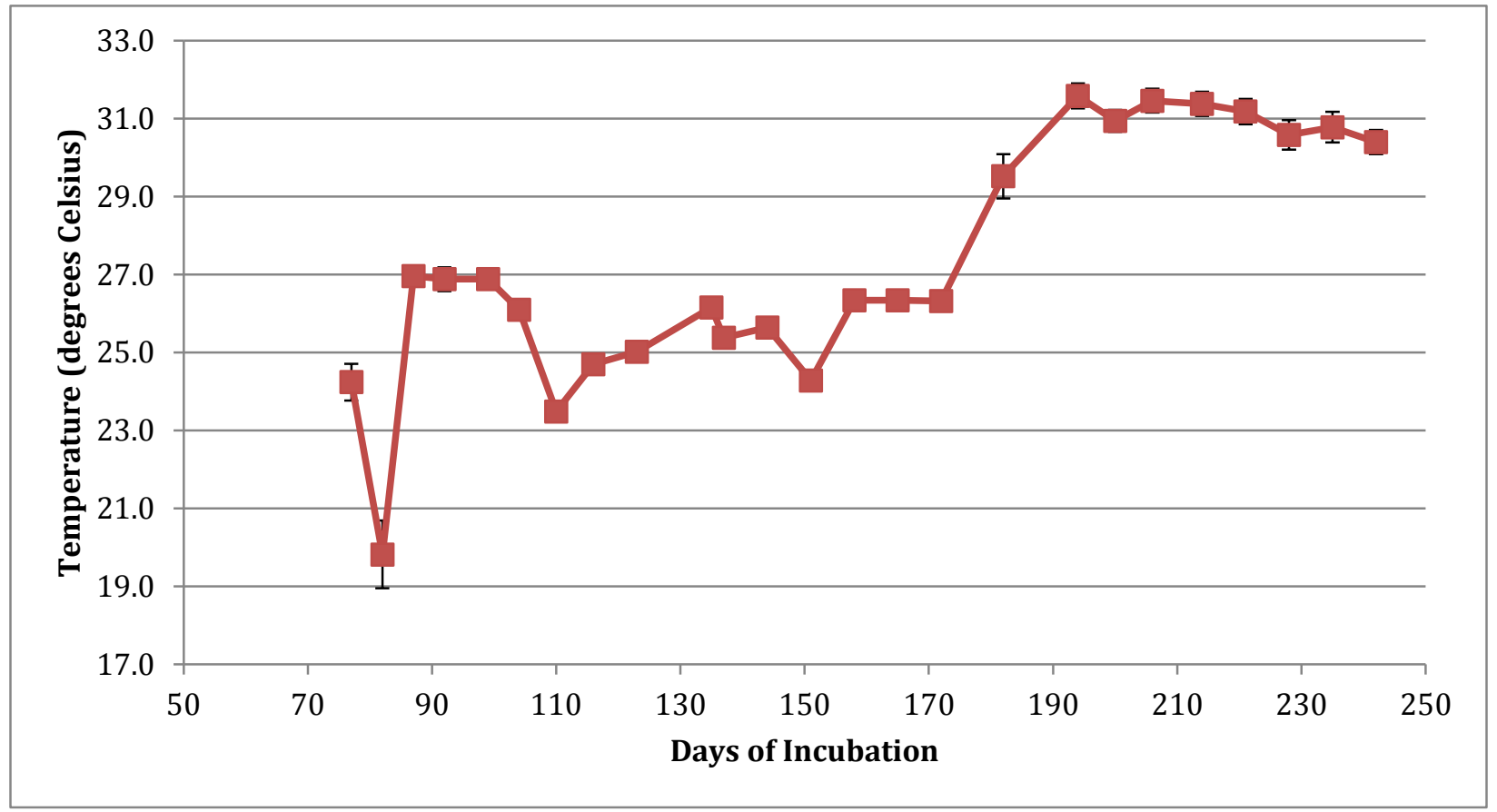

Figure 9: Microcosm incubator temperature during experiment 


\subsubsection{Contaminant Soil Concentrations in Microcosms During Incubation}

The total concentration of each contaminant type (EFH, PAHs, PCBs, and dioxins) were calculated and the averages and standard errors were plotted as a function of time to examine overall trends in chemical concentrations (Figures 10-14). More detailed data for each individual chemical are also provided in tables and graphs in Appendices A - D.

All statistical software outputs are provided as Appendices H, I, and J, respectively: Statistical Analysis of Effect of Treatment on Changes in Contaminant Concentrations in Soil A, Statistical Analysis of Effect of Gamma Irradiation on Changes in Contaminant Concentrations in Soil A, and Statistical Analysis of Different Soil Type (A, B, or C) on Changes in Contaminant Concentrations over Time.

\subsubsection{EFH}

Some of the observed EFH concentrations in microcosms are much higher than that observed for the collected soil (Table 9, Figure 10, Appendix A, and Appendix K). Initial concentrations were elevated in microcosms containing soy lecithin because some of its organic compounds elute at the same time as petroleum hydrocarbons during gas chromatography. This EFH inflation appeared to dissipate at the second sampling event, but EFH concentrations for all microcosms were elevated at the final sampling event. EFH values at the start of the experiment were clearly inflated by soy lecithin amendment (Figure 10). Apparently, organic compounds in the soya lecithin volatilize in the gas chromatograph at the same time as equivalent carbon ranges of some petroleum hydrocarbons. These EFH-mimicking components of soya lecithin are most likely biodegraded before the second sampling event. Since the corresponding apparent EFH 
concentrations were reduced substantially within 126 days, soil in these jars was not analyzed for EFH because of the interference by this amendment.

For the microcosms without soy lecithin interference, EFH concentrations were unchanged or decreased slightly during the first 126 days of incubation (Figure 10). Total EFH concentration appeared to increase substantially in all other microcosms at 244 days after the start of the experiment (Figure 10). This sudden increase was observed for both shorter equivalent carbon chains and longer equivalent carbon chains (Appendix A: Bar Graphs of EFH Equivalent Carbon Ranges). This increase in EFH concentration may have been a laboratory artifact since the Day 244 GC analyses were conducted by a different laboratory than the Day 0 and Day 126 analyses. For example, the two labs may have used different methods of integration or established a different baseline for integrating the chromatograms. 


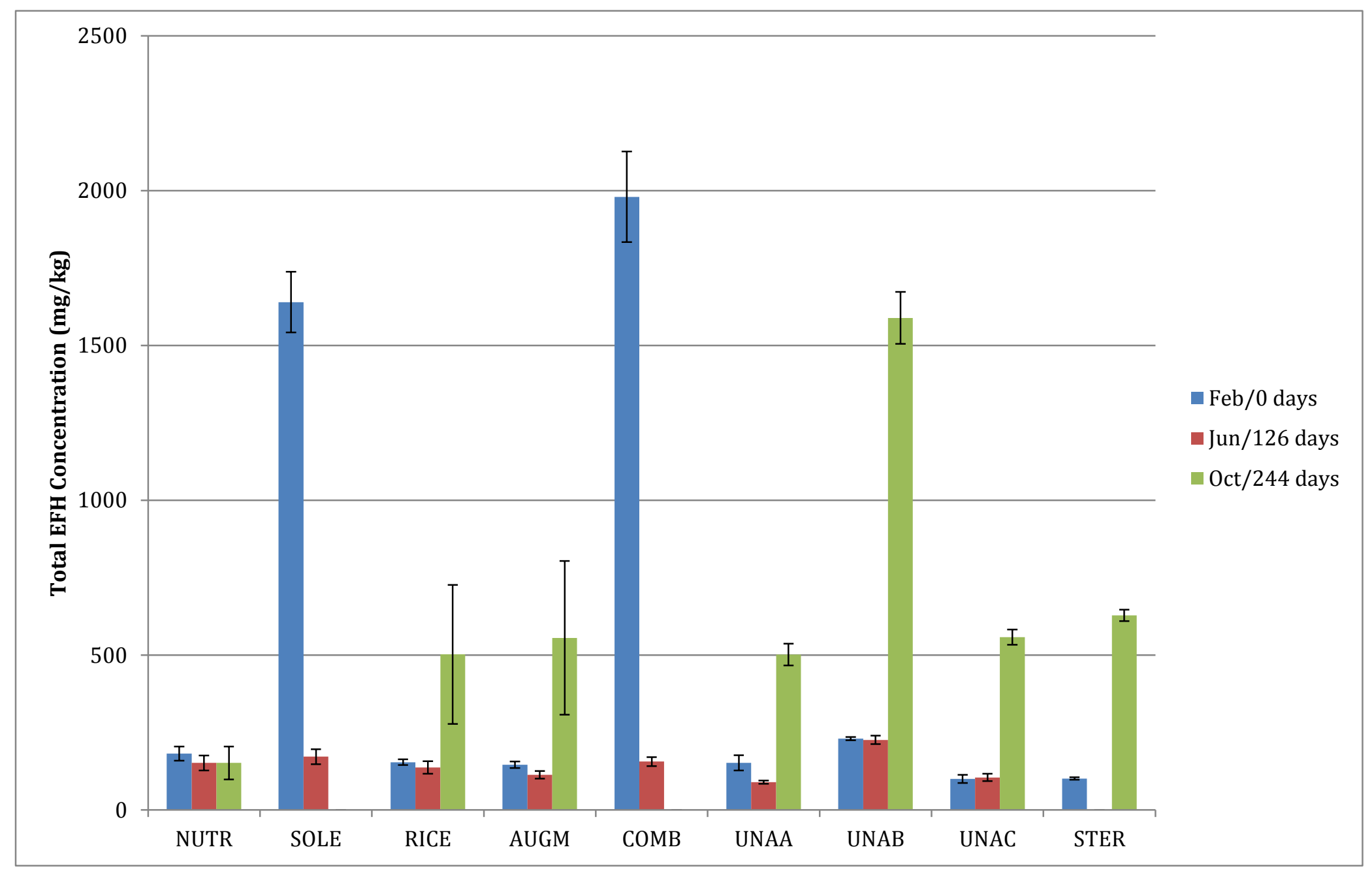

Figure 10: Total EFH concentration during microcosm incubation 


\subsubsection{PAHs}

Total PAH concentrations were calculated by summing all of the various PAH concentrations, as shown in Appendix K (Table 21). Concentrations of individual PAHs are shown in Table 19, Appendix K. Initial PAH concentrations were much higher in unamended B soils than both A and C soils (Figures 11 and 12). This is likely because soil B was located in a drainage into which PAH-contaminated water likely flowed.

PAH concentrations decreased slightly in Soil B during microcosm incubation (Figure 11). However, no decreases in PAH concentrations were not statistically significant with a 95\% confidence level (p-value of 0.296, Appendix F). For Soil C, total PAH concentrations also appeared to decrease dramatically, but the high variability of PAH concentrations measured (as indicated by the large error bars in Figure 12) led to no statistically significant change. For Soil A, total PAH concentration appeared to actually increase in several of the amended microcosms. This is undoubtedly due to the high variability of PAH concentrations measured.

The PAH contamination in these soils is largely comprised of compounds with 46 aromatic rings (Appendix C), and these are typically the most recalcitrant PAHs (Llado et al. 2013). Any degradation of lighter PAHs at the site is likely to have already occurred. If there were more PAHs with 1-3 aromatic rings in soil at one point in time, they have likely been preferentially degraded by microorganisms. Also, once PAHs adsorb onto soils, their biodegradation becomes difficult as their bioavailability is compromised. Residual contamination may be tightly adsorbed onto the soil matrix. However, surfactant addition to two sets of microcosms (SOLE and COMB) did not enhance PAH biodegradation (Figure 12). 


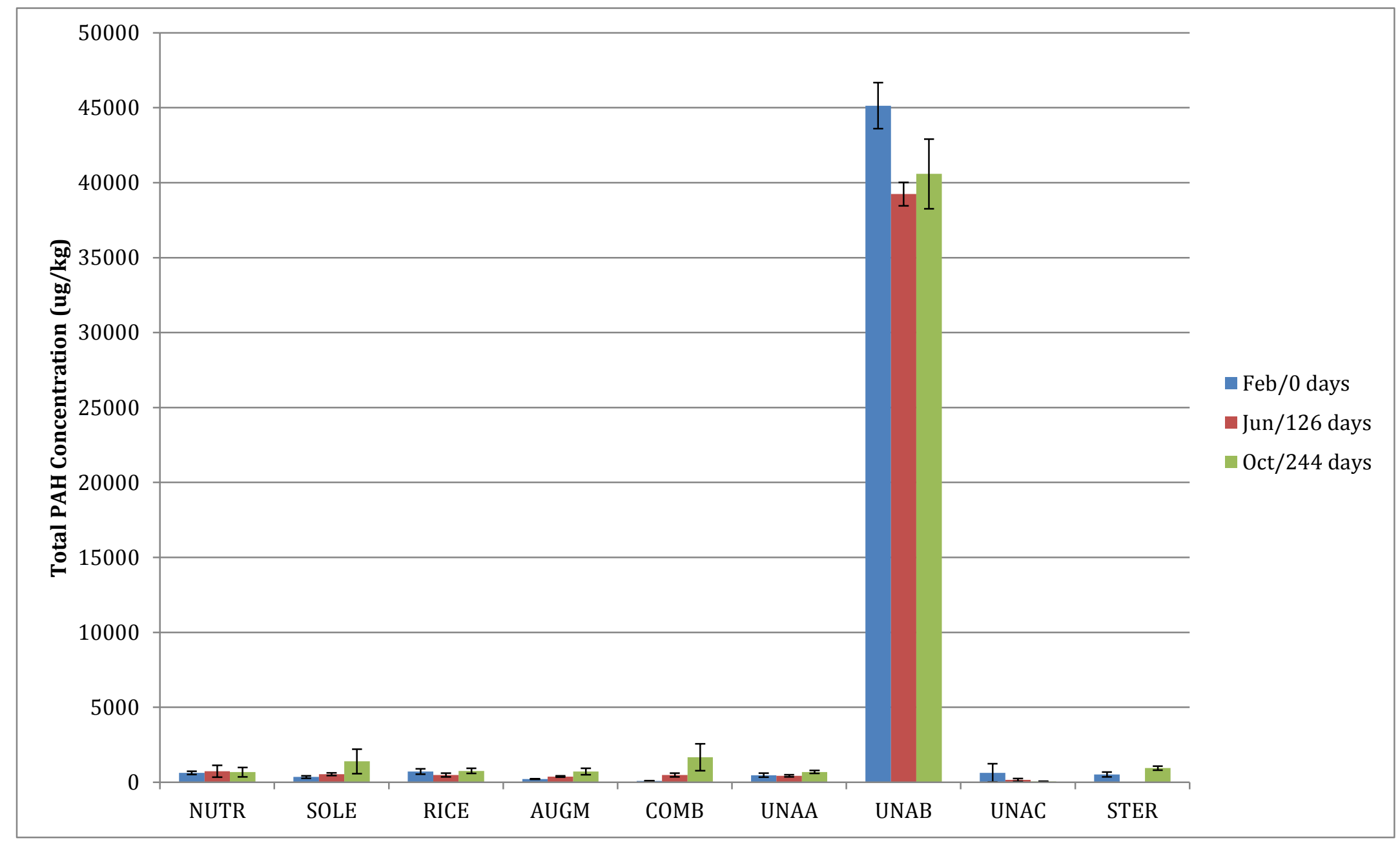

Figure 11: Total PAH concentration during microcosm incubation 


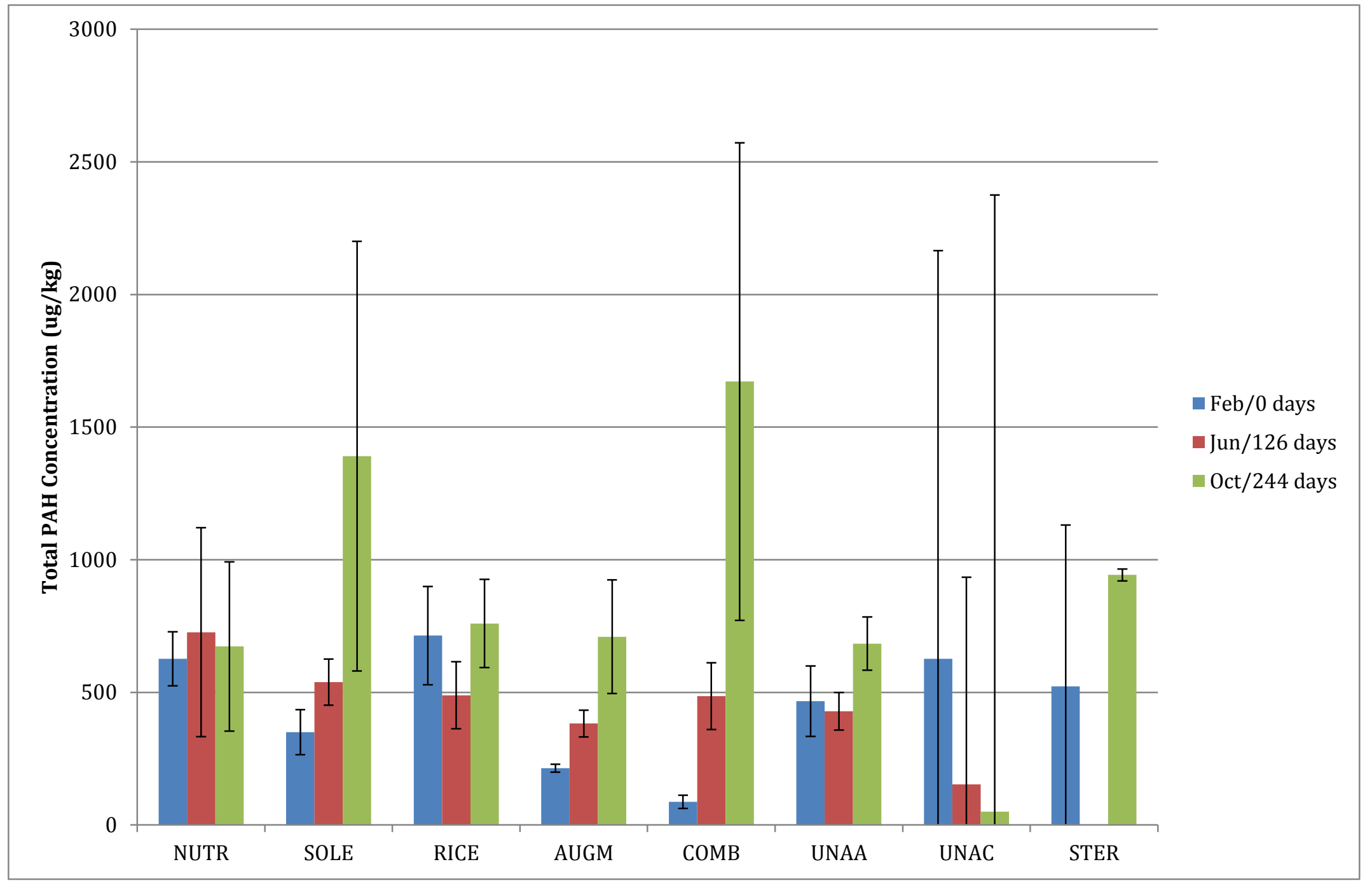

Figure 12: Total PAH concentration during microcosm incubation (A and C) 


\subsubsection{PCBs}

Slight decreases in Aroclor 1260 concentrations were observed in all but one of the microcosms (Figure 13). However, none of these decreases were statistically significant at the $95 \%$ confidence interval. Also, a similar decrease in PCB concentration was observed for the sterilized control. One set of microcosms (unamended A6) exhibited an exceptionally high initial PCB concentration which was caused by one sample with a particularly high initial PCB concentration. The Aroclor 1260 concentration appeared to increase for Soil C, but again this change was not statistically significant. Concentrations appeared to decrease for the most part over time, though comparison of treatments indicated that no treatment resulted in greater reduction in concentration than another at the $95 \%$ confidence level (Appendices $\mathrm{F}-\mathrm{H}$ ).

The lack of significant PCB biodegradation may be because detectable Aroclors detected at the site are the heaviest percent chlorine that were produced (54-60\% by weight). Lesser chlorinated PCBs with just 1-2 chlorines that have been to shown to degrade under aerobic conditions are only about $30 \%$ chlorine by weight, and it is likely that these compounds if present historically present at the site have already been degraded, and the more heavily chlorinated, recalcitrant compounds remain in the soil. The predominantly aerobic conditions at the site and in the microcosms make bacteriallymediated reductive dechlorination unlikely. Fungi such as P. chrysosporium, Sphingomonas wittichii have been shown to biodegrade PCBs under aerobic conditions, but in these experiments bioaugmentation with $P$. chrysosporium did not result in significantly more PCB degradation (Figures 3). Another possible limitation of PCB biodegradation is sequestration in the soil which limits bioavilability. However, even 
addition of soy lecithin as a surfactant to release PCBs from the soil structure did not facilitate significant PCB degradation. 


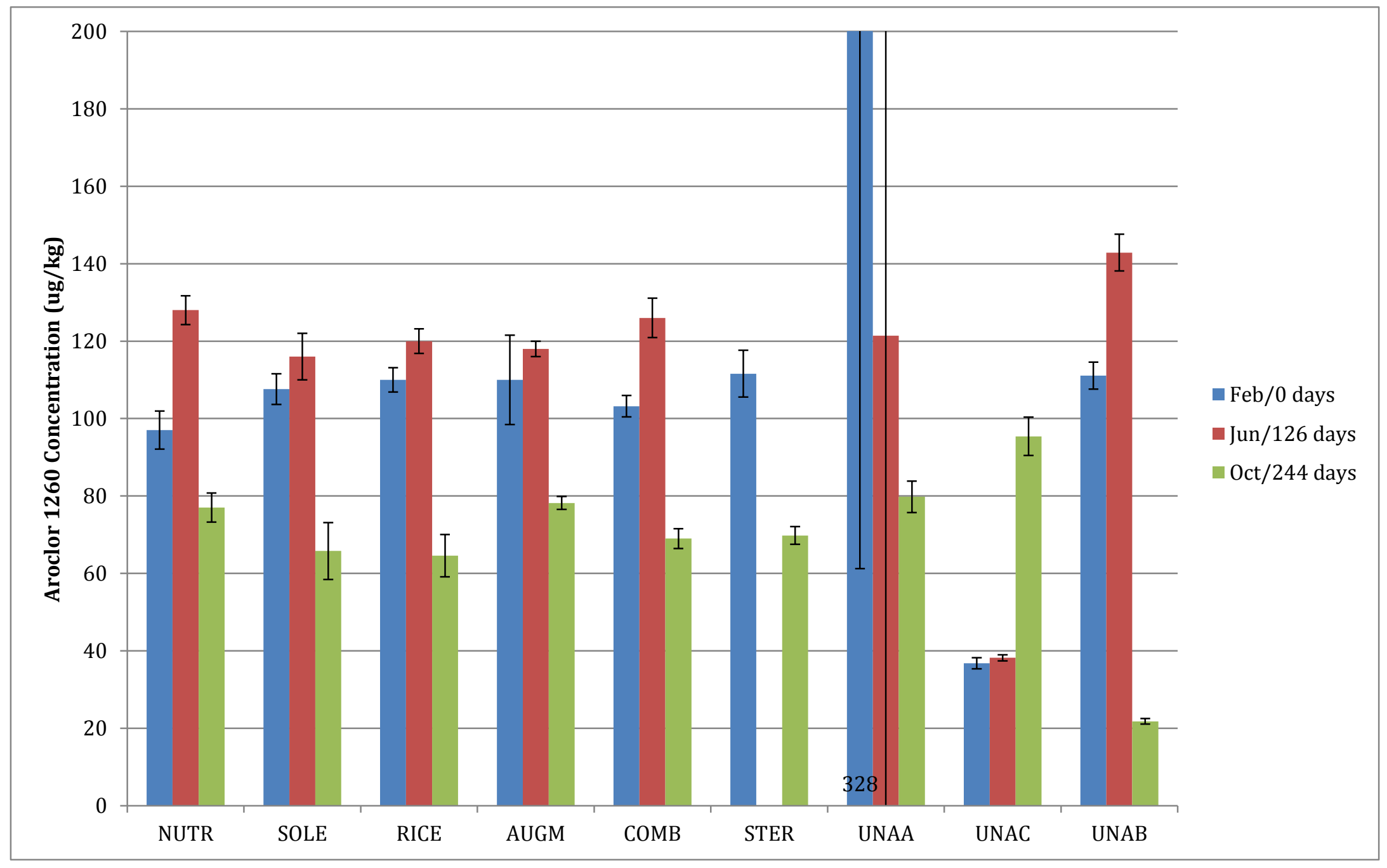

Figure 13: Aroclor 1260 concentration during microcosm incubation 


\subsubsection{Chlorinated Dioxins and TCDD TEQ}

Total chlorinated dioxin concentration increased on average in Soils B and C and decreased on average in Soil A. Total chlorinated dioxin concentration decreased noticeably only in the microcosms with Soil A amended with the combination of nutrients, rice hulls, and $P$. chrysosporium (AUGM) (Figure 14; also see Appendix B for more detail). However, this decrease was not statistically significant with $95 \%$ confidence in any of three statistical tests run on these data (Appendices F-H). For the same amendments with soy lecithin also added (COMB), no such decrease was observed (Figure 14). It is not clear why soy lecithin would interfere with biodegradation, unless its biodegradation consumed some nutrient needed for biodegradation. The sterile control held a constant dioxin concentration (Figure 14).

The lack of significant observed dioxin biodegradation may be because the primary dioxin contaminant at the site is OCDD, which is the most heavily chlorinated dioxin congener. These highly chlorinated dioxins require anaerobic conditions to be bacterially dechlorinated, but site and experimental conditions were aerobic. Biodegradation under aerobic conditions may be possible with fungi such as $P$. chrysosporium, and indeed bioagumentation with this fungi appears to have aided dioxin biodegradtion, but again this observation was not statistically significant.

The dioxin source at the site could be from natural fires, or from anthropogenic sources. According to a paper citing congener profiles for anthropogenic sources of chlorinated DD/DFs, OCDD is the primary congener emitted from several industrial sources: municipal solid waste incineration with dry scrubbers and fabric filters for dioxin controls, industrial oil-fired boilers, industrial wood-fired boilers, unleaded 
gasoline combustion, diesel fuel combustion, and from sewage sludge incineration (Cleverly et al. 1997). Burning of hazardous waste results in minor OCDD and OCDF stack emissions. However, savanna woodland and arid grassland fires also produce DD/DFs dominated by OCDD (MacDougall, Rillig, and Klironomos 2011). Savanna woodlands seem to resemble SSFL site conditions (a grassland ecosystem with trees spaced so that the canopy does not close, seasonal water availability, and in the transitional zone between forest and desert or grassland) suggesting that emissions from a wildfire at SSFL might have contributed to the OCDDs as well.

TCDD TEQ, an important measure of dioxin congeners' toxicity, did not appear to decrease for any of the treatments (Figure 15). 


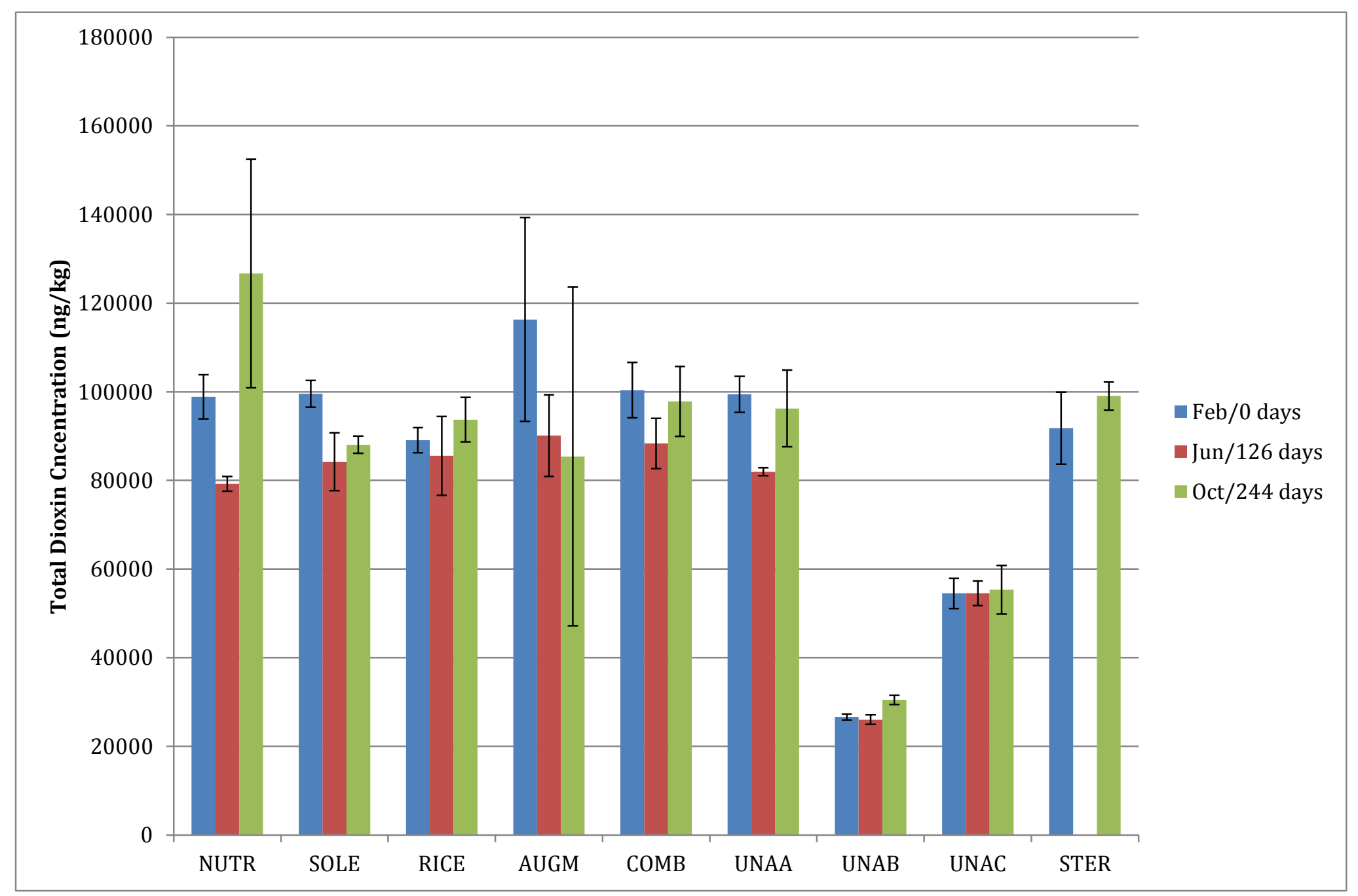

Figure 14: Total dioxin concentration during microcosm incubation 


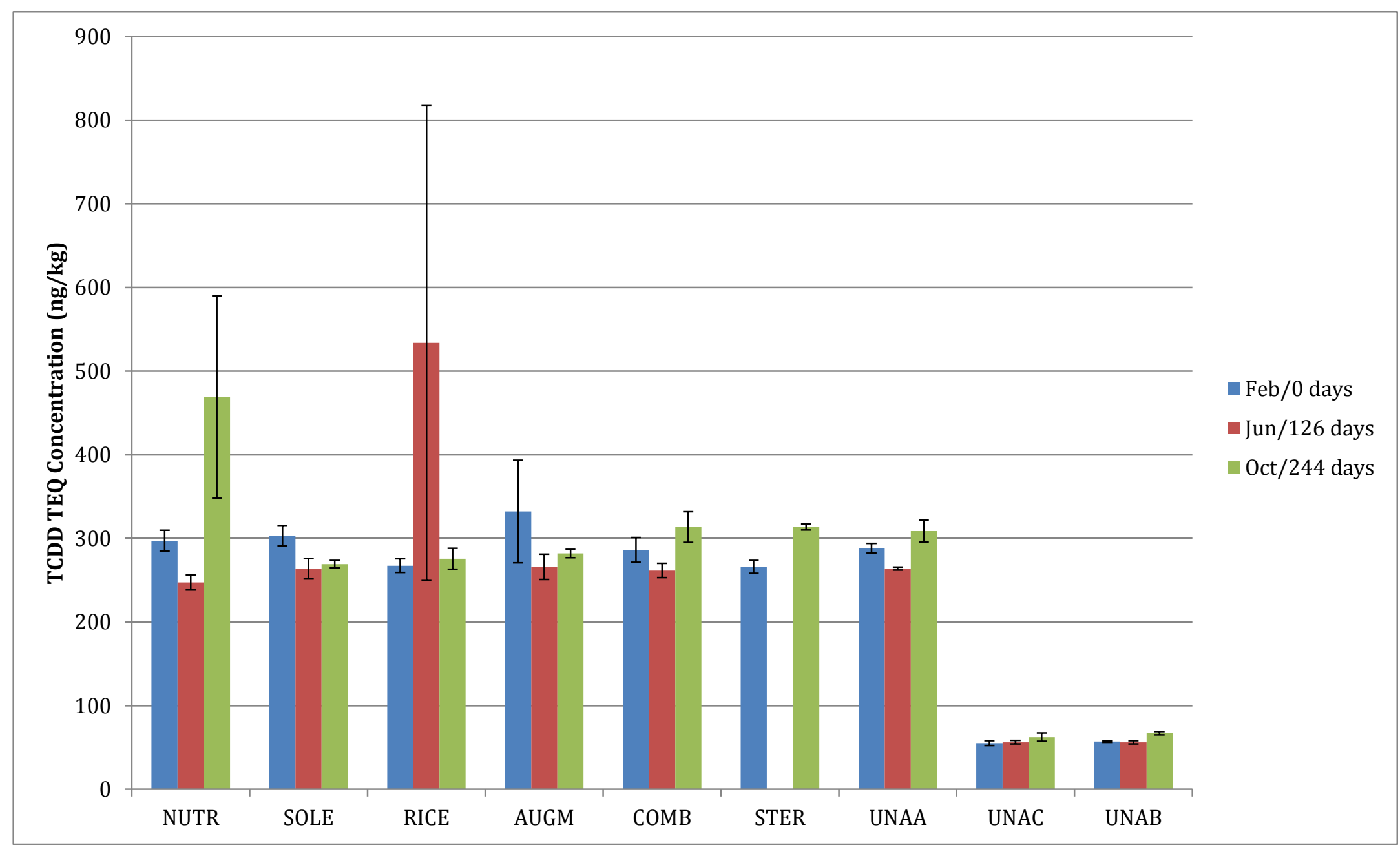

Figure 15: TCDD TEQ concentration during microcosm incubation 


\subsection{CONCLUSIONS AND RECOMMENDATIONS}

Only slight decreases in PAH, PCB, and dioxin concentrations were observed over the 244-day soil microcosm experiment, and the difference in concentration reduction between treatments was not statistically significant with $95 \%$ confidence. Conclusions could not be made about petroleum hydrocarbon biodegradation because EFH measurements were compromised by the use of two different analytical labs for initial and final analyses. Natural attenuation rates of the COIs appear to be very slow, indicating that a long time would be required to reach acceptable COI concentrations. Amendments tested in this study for biostimulation and/or bioaugmentation (nutrients, soy lecithin, rice hulls, and $P$. chrysosporium) also did not result in statistically significant reductions in PAH, dioxin, or PCB concentrations in SSFL soils.

The lack of significant observed biodegradation is likely because the COIs in the site soil are highly weathered. Such weathering results in adsorption onto the soil matrix which can limit the bioavailability of contaminants. Also, after weathering, the forms of the COIs found in these soils are the more recalcitrant forms of these COIs. Weathered $\mathrm{EFH}$ is composed of longer equivalent carbon chains, $\mathrm{PAH}$ contamination is composed of compounds with 4-6 aromatic rings, the most abundant dioxin congener is OCDD, and the PCBs are comprised of the highly chlorinated Aroclor mixtures. Because of the site's aerobic conditions, it is unlikely that heavily chlorinated compounds will reductively dechlorinate over time. Heavier PAHs are also unlikely to biodegrade under these conditions. It is likely that organic carbon at the site acts as a long-term sink for PAH contamination. 
It is difficult to determine a source of dioxins at the site. OCDD/Fs are generated by both forest fires and anthropogenic sources. Perhaps a study of the land surrounding SSFL that was also burned in the Topanga Wildfire might help to determine an appropriate background dioxin level to compare to SSFL soil chlorinated dioxin concentrations.

This experiment was short compared to the age of SSFL contamination. As stated in the introduction, some contaminants have persisted at the site for over 40 years, and a 244-day study may not accurately model COI degradation. However, some kinetic estimations were made using microcosm experiments (Appendix M). Assuming zeroorder kinetics, contaminants may take less than a year to three years to reack Look-Up Table values. Assuming first-order kinetics, dioxins and PAHs may take up to 20-30 years to reach Look-Up Table values (Appendix M). This is a narrower range of time required to reach Look-Up Table values than that provided in the December Natural Attenuation Report.

Although this experiment did not result in significant bioremediation rates, it shed light on much information that can be used in future studies. First, soils should be adequately contaminated to observe degradation. In some cases, COI concentrations were too low to observe a decreasing trend due to soil variability. In addition, consistent experimental conditions are essential to minimize variability. Furthermore, methods should be kept consistent to prevent data anomalies and unexpected fluctuations in concentrations. All analyses should be performed by the same lab if at all possible, and integration techniques should be clearly delineated so methods can be reproduced. 
In conclusion, this experiment indicated that natural attenuation and/or bioremediation of COIs at SSFL is likely to require extensive time. Although unfortunate, this is valuable information for moving forward to clean up the site and let the public embrace its natural beauty. 


\section{REFERENCES}

Abdulsalam, S., I. M. Bugaje, S. S. Adefila, and S. Ibrahim. 2011. "Comparison of Biostimulation and Bioaugmentation for Remediation of Soil Contaminated with Spent Motor Oil." International Journal of Environmental Science and Technology 8 (1): 187-94.

Abo-El-Seoud, El-Mataium-Mufeed, Kreuzig, and Batarseh. 2004. "Impact of Gamma Radiation on the Degradability of Polynuclear Aromatic Hydrocarbons in Egyptian Sewage Sludge.” Fresenius Environmental Bulletin 13 (1): 52-55.

Andreoni, V., L. Cavalca, M.A. Rao, G. Nocerino, S. Bernasconi, E. Dell'Amico, M. Colombo, and L. Gianfreda. 2004. "Bacterial Communities and Enzyme Activities of PAHs Polluted Soils." Chemosphere 57 (5): 401-12. doi:10.1016/j.chemosphere.2004.06.013.

Arfmann, H. A., K. N. Timmis, and R. M. Wittich. 1997. "Mineralization of 4Chlorodibenzofuran by a Consortium Consisting of Sphingomonas Sp. Strain RW1 and Burkholderia Sp. Strain JWS." Applied and Environmental Microbiology 63 (9): 3458-62.

Aronstein, Bn, Ym Calvillo, and M. Alexander. 1991. "Effect of Surfactants at Low Concentrations on the Desorption and Biodegradation of Sorbed AromaticCompounds in Soil." Environmental Science \& Technology 25 (10): 1728-31. doi:10.1021/es00022a008.

Aronstein, Bn, and Jr Paterek. 1995. "Effect of Nonionic Surfactant on the Degradation of Glass-Sorbed Pcb Congeners by Integrated Chemical Biological Treatment." Environmental Toxicology and Chemistry 14 (5): 749-54. doi:10.1897/15528618(1995)14[749:EONSOT]2.0.CO;2.

ASTM Standard D2216, "Standard Test Methods for Laboratory Determination of Water (Moisture) Content of Soil and Rock by Mass.” 2010. Vol. 04.08. West Conshohocken, PA: ASTM International. www.astm.org.

Baboshin, M. A., and L. A. Golovleva. 2012. "Aerobic Bacterial Degradation of Polycyclic Aromatic Hydrocarbons (PAHs) and Its Kinetic Aspects." Microbiology 81 (6): 639-50. doi:10.1134/S0026261712060021.

Bartha, R., and I. Bossert. 1984. "The Treatment and Disposal of Petroleum Wastes." Petroleum Microbiology, 553-78. 
Bedard, Donna L., Kirsti A. Ritalahti, and Frank E. Loffler. 2007. “The Dehalococcoides Population in Sediment-Free Mixed Cultures Metabolically Dechlorinates the Commercial Polychlorinated Biphenyl Mixture Aroclor 1260." Applied and Environmental Microbiology 73 (8): 2513-21. doi:10.1128/AEM.02909-06.

Bento, F. M., F. a. O. Camargo, B. C. Okeke, and W. T. Frankenberger. 2005. "Comparative Bioremediation of Soils Contaminated with Diesel Oil by Natural Attenuation, Biostimulation and Bioaugmentation." Bioresource Technology 96 (9): 1049-55. doi:10.1016/j.biotech.2004.09.008.

Boening, D. W. 1998. "Toxicity of 2,3,7,8-Tetrachlorodibenzo-P-Dioxin to Several Ecological Receptor Groups: A Short Review." Ecotoxicology and Environmental Safety 39 (3): 155-63. doi:10.1006/eesa.1997.1608.

Boldrin, B., A. Tiehm, and C. Fritzsche. 1993. "Degradation of Phenanthrene, Fluorene, Fluoranthene, and Pyrene by a Mycobacterium Sp." Applied and Environmental Microbiology 59 (6): 1927-30.

Brusseau, M. L. 1998. “The Impact of Physical, Chemical and Biological Factors on Biodegradation." Proceedings of the International Conference on Biotechnology for Soil Remediation: Scientific Bases and Practical Applications, 81-98.

Carmichael, L. M., and F. K. Pfaender. 1997. "The Effect of Inorganic and Organic Supplements on the Microbial Degradation of Phenanthrene and Pyrene in Soils." Biodegradation 8 (1): 1-13.

Center for Disease Control. "PCBs: Chemical and Physical Properties." In . http://www.atsdr.cdc.gov/toxprofiles/tp17-c4.pdf.

Cerniglia, Carl E. 1992. "Biodegradation of Polycyclic Aromatic Hydrocarbons." Biodegradation 3 (2-3): 351-68. doi:10.1007/BF00129093.

Chaillan, F., C. H. Chaineau, V. Point, A. Saliot, and J. Oudot. 2006. "Factors Inhibiting Bioremediation of Soil Contaminated with Weathered Oils and Drill Cuttings." Environmental Pollution 144 (1): 255-65.

Chaillan, F., A. Le Fleche, and E. Bury et al. 2004. "Identification and Biodegradation Potential of Tropical Aerobic Hydrocarbon-Degrading Microorganisms." Research in Microbiology 155 (7): 587-95.

Chaineau, C. H., G. Rougeux, C. Yepremian, and J. Oudot. 2005. "Effects of Nutrient Concentration on the Biodegradation of Crude Oil and Associated Microbial Populations in the Soil." Soil Biology and Biochemistry 37 (8): 1490-97. 
Chrzanowski, Lukasz, Mariusz Dziadas, Lukasz Lawniczak, Pawel Cyplik, Wojciech Bialas, Alicja Szulc, Piotr Lisiecki, and Henryk Jelen. 2012. "Biodegradation of Rhamnolipids in Liquid Cultures: Effect of Biosurfactant Dissipation on Diesel fuel/B20 Blend Biodegradation Efficiency and Bacterial Community Composition.” Bioresource Technology 111 (May): 328-35. doi:10.1016/j.biortech.2012.01.181.

Cleverly, D., J. Schaum, G. Schweer, J. Becker, and D. Winters. 1997. “The Congener Profiles of Anthropogenic Sources of Chlorinated Dibenzo-P-Dioxins and Chlorinated Dibenzofurans in the United States." Presentation at Dioxin '97, the 17th Internationl Symposium on Chlorinated Dioxins and Related Compounds 32 (August): 430-35.

Collins, David, Mark Sherwin, and Dixie Hambrick. 2013. "Rough Order of Magnitude Estimates for AOC Soil Cleanup Volumes in Area IV, and Associated Truck Transport Estimates Based on DTSC Look-up Table Values - DRAFT", September 4.

http://ssflcag.net/resources/Draft_Area_IV_ROM_Soil_Volume_Estimate_02071 4.pdf.

Cooney, J. J. 1984. "The Fate of Petroleum Pollutants in Fresh Water Ecosystems." Petroleum Microbiology, 399-434.

Couto, M. Nazare P. F. S., Emanuela Monteiro, and M. Teresa S. D. Vasconcelos. 2010. "Mesocosm Trials of Bioremediation of Contaminated Soil of a Petroleum Refinery: Comparison of Natural Attenuation, Biostimulation and Bioaugmentation." Environmental Science and Pollution Research 17 (7): 133946. doi:10.1007/s11356-010-0318-y.

Croyle, Kenneth. 2014. "Assessmet of Microbial Biodegradation of Mixed Soil Contaminants at the Santa Susana Field Laboratory Using TRFLP, qPCR, and Culturing". Thesis, San Luis Obispo, CA: California Polytechnic State University. Accessed December 10.

http://digitalcommons.calpoly.edu/cgi/viewcontent.cgi?article=2395\&context=the ses.

Das, Nilanjana, and Preethy Chandran. 2010. "Microbial Degradation Fo Petroleum Hydrocarbon Contaminants: An Overview." Environmental Biotechnology Division, School of Biosciences and Technology, VIT University, Vellore, Tamil Nadu 632014, India, July.

Doick, K. J., and K. T. Semple. 2004. Impact of Transformer Oil on Phenanthrene Ageing in Soil. Edited by V. S. Magar and M. E. Kelley. Colombus, USA: Battelle Press. 
Eaton, Rw, and Pj Chapman. 1992. "Bacterial Metabolism of Naphthalene - Construction and Use of Recombinant Bacteria to Study Ring Cleavage of 1,2-

Dihydroxynaphthalene and Subsequent Reactions." Journal of Bacteriology 174 (23): 7542-54.

Environmental Protection Agency. 2014. "Persistent Organic Pollutants: A Global Issue, A Global Response”. Government Agency. Environmental Protection Agency. June 12. http://www2.epa.gov/international-cooperation/persistent-organicpollutants-global-issue-global-response.

EPA. 2013a. "Use of Dioxin TEFs in Calculating Dioxin TEQs at CERCLA and RCRA Sites", May.

http://www.epa.gov/superfund/health/contaminants/dioxin/pdfs/Use_of_Dioxin_T EFs_in_Calculating_Dioxin_TEQs_at_CERCLA_and_RCRA_Sites.pdf.

_. 2013b. "Priority Pollutants." Appendix A to 40 CFR Part 423, Priority Pollutants. August 22. http://water.epa.gov/scitech/methods/cwa/pollutants.cfm.

Fagervold, Sonja K., Joy E.M. Watts, Harold D. May, and Kevin R. Sowers. 2011. "Effects of Bioaugmentation on Indigenous PCB Dechlorinating Activity in Sediment Microcosms." Water Research 45 (13): 3899-3907. doi:10.1016/j.watres.2011.04.048.

Fava, Fabio, Sara Berselli, Pellegrino Conte, Alessandro Piccolo, and Leonardo Marchetti. 2004. "Effects of Humic Substances and Soya Lecithin on the Aerobic Bioremediation of a Soil Historically Contaminated by Polycyclic Aromatic Hydrocarbons (PAHs)." Biotechnology and Bioengineering 88 (2): 214-23. doi:10.1002/bit.20225.

Federici, Ermanno, Ermanno Giubilei, Santi Guglielmo, Giulio Zanaroli, Andrea Negroni, Fabio Fava, Maurizio Petruccioli, and Alessandro D’Annibale. 2012. "Bioaugmentation of a Historically Contaminated Soil by Polychlorinated Biphenyls with Lentinus Tigrinus.” Microbial Cell Factories 11: 35. doi:10.1186/1475-2859-11-35.

Field, Jim A., and Reyes Sierra-Alvarez. 2008a. "Microbial Degradation of Chlorinated Dioxins." Chemosphere 71 (6): 1005-18. doi:10.1016/j.chemosphere.2007.10.039.

- 2008b. "Microbial Transformation and Degradation of Polychlorinated Biphenyls." Environmental Pollution 155 (1): 1-12. doi:10.1016/j.envpol.2007.10.016.

Franzetti, Andrea, Paolo Caredda, Claudio Ruggeri, Paolo La Colla, Elena Tamburini, Maddalena Papacchini, and Giuseppina Bestetti. 2009. "Potential Applications of 
Surface Active Compounds by Gordonia Sp Strain BS29 in Soil Remediation Technologies." Chemosphere 75 (6): 801-7.

doi:10.1016/j.chemosphere.2008.12.052.

Gibson, D. T., and R. E. Parales. 2000. "Aromatic Hydrocarbon Dioxygenases in Environmental Biotechnology." Current Opinion in Biotechnology 11 (3): 23643. doi:10.1016/S0958-1669(00)00090-2.

Gorna, Hanna, Lukasz Lawniczak, Agnieszka Zgola-Grzeskowiak, and Ewa Kaczorek. 2011. "Differences and Dynamic Changes in the Cell Surface Properties of Three Pseudomonas Aeruginosa Strains Isolated from Petroleum-Polluted Soil as a Response to Various Carbon Sources and the External Addition of Rhamnolipids.” Bioresource Technology 102 (3): 3028-33. doi:10.1016/j.biortech.2010.09.124.

Habe, H., K. Ide, M. Yotsumoto, H. Tsuji, H. Hirano, J. Widada, T. Yoshida, H. Nojiri, and T. Omori. 2001. "Preliminary Examinations for Applying a CarbazoleDegrader, Pseudomonas Sp Strain CA10, to Dioxin-Contaminated Soil Remediation." Applied Microbiology and Biotechnology 56 (5-6): 788-95.

Harkness, Mr, Jb Mcdermott, Da Abramowicz, Jj Salvo, Wp Flanagan, Ml Stephens, Fj Mondello, et al. 1993. "Insitu Stimulation of Aerobic Pcb Biodegradation in Hudson River Sediments." Science 259 (5094): 503-7. doi:10.1126/science.8424172.

Hollaway, S. L., G. M. Faw, and R. K. Sizemore. 1980. "The Bacterial Community Composition of an Active Oil Field in the Northwestern Gulf of Mexico." Marine Pollution Bulletin 11 (6): 153-56.

Hong, H. B., Y. S. Chang, I. H. Nam, P. Fortnagel, and S. Schmidt. 2002. "Biotransformation of 2,7-Dichloro- and 1,2,3,4-Tetrachlorodibenzo-P-Dioxin by Sphingomonas Wittichii RW1." Applied and Environmental Microbiology 68 (5): 2584-88. doi:10.1128/AEM.68.5.2584-2588.2002.

Hwang, S., and T.J. Cutright. 2002. "Biodegradability of Aged Pyrene and Phenanthrene in a Natural Soil." Chemosphere 47 (9): 891-99. doi:10.1016/S00456535(02)00016-4.

Hwang, Sangchul, and Teresa J. Cutright. 2004. "Preliminary Exploration of the Relationships between Soil Characteristics and PAH Desorption and Biodegradation.” Environment International 29 (7): 887-94. doi:10.1016/S01604120(03)00053-9.

"In Situ Biological Treatment". Government. Federal Remediation Technologies Roundtable. http://www.frtr.gov/matrix2/section4/4_1.html. 
Inakollu, S., H. C. Hung, and G. S. Shreve. 2004. "Biosurfactant Enhancement of Microbial Degradation of Various Structural Classes of Hydrocarbon in Mixed Waste Systems.” Environmental Engineering Science 21 (4): 463-69. doi:10.1089/1092875041358467.

Johnsen, Anders R., Lukas Y. Wick, and Hauke Harms. 2005. "Principles of Microbial PAH-Degradation in Soil." Environmental Pollution 133: 71-84. doi:10.1016/j.envpol.2004.04.015.

Johnson, Glenn W., Larry G. Hansen, M. Coreen Hamilton, Brian Fowler, and Mark H. Hermanson. 2008. "PCB, PCDD and PCDF Congener Profiles in Two Types of Aroclor 1254." Environmental Toxicology and Pharmacology 25 (2): 156-63. doi:10.1016/j.etap.2007.10.011.

Jones, J., M. Knight, and J. A. Byron. 1970. "Effect of Gross Population by Kerosene Hydrocarbons on the Microflora of a Moorland Soil." Nature 227: 1166.

Kearney, Pc, Ea Woolson, and Cp Ellingto. 1972. "Persistence and Metabolism of Chlorodioxins in Soils." Environmental Science \& Technology 6 (12): 1017-\&. doi:10.1021/es60071a010.

Kjellerup, Birthe V., Piuly Paul, Upal Ghosh, Harold D. May, and Kevin R. Sowers. 2012. "Spatial Distribution of PCB Dechlorinating Bacteria and Activities in Contaminated Soil." Applied and Environmental Soil Science 2012 (June). doi:10.1155/2012/584970.

Kobayashi, Takayuki, Hirohisa Kaminaga, Ronald R. Navarro, and Yosuke Iimura. 2012. "Application of Aqueous Saponin on the Remediation of Polycyclic Aromatic Hydrocarbons-Contaminated Soil." Journal of Environmental Science and Health Part a-Toxic/Hazardous Substances \& Environmental Engineering 47 (8): 113845. doi:10.1080/10934529.2012.668106.

Krumins, Valdis, Joong-Wook Park, Eun-Kyeu Son, Lisa A. Rodenburg, Lee J. Kerkhof, Max M. Haeggblom, and Donna E. Fennell. 2009. "PCB Dechlorination Enhancement in Anacostia River Sediment Microcosms." Water Research 43 (18): 4549-58. doi:10.1016/j.watres.2009.08.003.

Landers, Jp, and $\mathrm{Nj}$ Bunce. 1991. "The Ah Receptor and the Mechanism of Dioxin Toxicity." Biochemical Journal 276 (June): 273-87.

Lawniczak, Lukasz, Roman Marecik, and Lukasz Chrzanowski. 2013. "Contributions of Biosurfactants to Natural or Induced Bioremediation.” Applied Microbiology and Biotechnology 97 (6): 2327-39. doi:10.1007/s00253-013-4740-1. 
Lee, Eun-Hee, Yeon-Sil Kang, and Kyung-Suk Cho. 2011. "Bioremediation of DieselContaminated Soils by Natural Attenuation, Biostimulation and Bioaugmentation Employing Rhodococcus Sp EH831." Korean Journal of Microbiology and Biotechnology 39 (1): 86-92.

Lin, Ta-Chen, Po-Tsen Pan, Chiu-Chung Young, Jo-Shu Chang, Tsung-Chung Chang, and Sheng-Shung Cheng. 2011. "Evaluation of the Optimal Strategy for Ex Situ Bioremediation of Diesel Oil-Contaminated Soil." Environmental Science and Pollution Research 18 (9): 1487-96. doi:10.1007/s11356-011-0485-5.

Llado, S., S. Covino, A. M. Solanas, M. Vinas, M. Petruccioli, and A. D'annibale. 2013. "Comparative Assessment of Bioremediation Approaches to Highly Recalcitrant PAH Degradation in a Real Industrial Polluted Soil." Journal of Hazardous Materials 248 (March): 407-14. doi:10.1016/j.jhazmat.2013.01.020.

MacDougall, Andrew S., Matthias C. Rillig, and John N. Klironomos. 2011. "Weak Conspecific Feedbacks and Exotic Dominance in a Species-Rich Savannah." Proceedings of the Royal Society B-Biological Sciences 278 (1720): 2939-45. doi:10.1098/rspb.2010.2730.

Malina, G., and I. Zawierucha. 2007. "Potential of Bioaugmentation and Biostimulation for Enhancing Intrinsic Biodegradation in Oil Hydrocarbon-Contaminated Soil." Bioremediation Journal 11 (3): 141-47. doi:10.1080/10889860701548648.

Mancera-López, M.E., F. Esparza-García, B. Chávez-Gómez, R. Rodríguez-Vázquez, G. Saucedo-Castañeda, and J. Barrera-Cortés. 2008. "Bioremediation of an Aged Hydrocarbon-Contaminated Soil by a Combined System of Biostimulationbioaugmentation with Filamentous Fungi." International Biodeterioration \& Biodegradation 61 (2): 151-60. doi:10.1016/j.ibiod.2007.05.012.

Mukherjee, Ashis K., and Kishore Das. 2010. "Microbial Surfactants and Their Potential Applications: An Overview." In Biosurfactants, edited by R. Sen, 672:54-64. Berlin: Springer-Verlag Berlin.

Mulkins Phillips, G. J., and J. E. Stewart. 1974. "Distribution of Hydrocarbon Utilizing Bacteria in Northwestern Atlantic Waters and Coastal Sediments." Canadian Journal of Microbiology 20 (7): 955-62.

Mulligan, C. N., R. N. Yong, and B. F. Gibbs. 2001. "Surfactant-Enhanced Remediation of Contaminated Soil: A Review.” Engineering Geology 60 (1-4): 371-80. doi:10.1016/S0013-7952(00)00117-4.

Neu, T. R. 1996. "Significance of Bacterial Surface-Active Compounds in Interaction of Bacteria with Interfaces." Microbiological Reviews 60 (1): 151-+. 
Nojiri, H., H. Habe, and T. Omori. 2001. "Bacterial Degradation of Aromatic Compounds via Angular Dioxygenation." Journal of General and Applied Microbiology 47 (6): 279-305. doi:10.2323/jgam.47.279.

Oberg, Lg, and C. Rappe. 1992. "Biochemical Formation of Pcdd/Fs from Chlorophenols." Chemosphere 25 (1-2): 49-52. doi:10.1016/00456535(92)90477-9.

Oudot, J., F. X. Merlin, and P. Pinvidic. 1998. "Weathering Rates of Oil Components in a Bioremediation Experiment in Estuarine Sediments." Marine Environmental Research 45 (2): 113-25.

Ouvrard, Stephanie, Elodie-Denise Chenot, Jean-Francois Masfaraud, and Christophe Schwartz. 2013. "Long-Term Assessment of Natural Attenuation: Statistical Approach on Soils with Aged PAH Contamination." Biodegradation 24 (4): 539 48. doi:10.1007/s10532-013-9618-5.

Payne, Rayford B., Harold D. May, and Kevin R. Sowers. 2011. "Enhanced Reductive Dechlorination of Polychlorinated Biphenyl Impacted Sediment by Bioaugmentation with a Dehalorespiring Bacterium.” Environmental Science \& Technology 45 (20): 8772-79. doi:10.1021/es201553c.

Pinholt, Y., S. Struwe, and A. Kjoller. 1979. "Microbial Changes during Soil Decomposition in Soil." Holarctic Ecology 2: 195-200.

Pitter, P, and J Chudoba. 1990. Biodegradability of Organic Substances in the Aquatic Environment.

Pohjanvirta, R., and J. Tuomisto. 1994. "Short-Term Toxicity of 2,3,7,8Tetrachlorodibenzo-P-Dioxin in Laboratory-Animals - Effects, Mechanisms, and Animal-Models." Pharmacological Reviews 46 (4): 483-549.

Providenti, Ma, Ca Flemming, H. Lee, and Jt Trevors. 1995. "Effect of Addition of Rhamnolipid Biosurfactants or Rhamnolipid-Producing Pseudomonas-Aeruginosa on Phenanthrene Mineralization in Soil Slurries." Fems Microbiology Ecology 17 (1): 15-26. doi:10.1111/j.1574-6941.1995.tb00123.x.

Rahman, Banat, Thahira, Thayumanavan, and Lakshmanaperumalsamy. 2002. "Bioremediation of Gasoline Contaminated Soil by a Bacterial Consortium Amended with Poultry Litter, Coir Pith, and Rhamnolipid Biosurfactant." Bioresource Technology 81 (1): 25-32. doi:10.1016/S0960-8524(01)00105-5.

Rahman, P. K. S. M., and E. Gakpe. 2008. "Production, Characterisation and Applications of Biosurfactants-Review." Biotechnology 7 (2). 
Rastegarzadeh, L., Y. Nelson, and G. T. Ririe. 2006. Biotreatment of Synthetic DrillCutting Waste in Soil. Edited by B. M. Sass. Colombus, USA: Battelle Press.

Richardson, Stephen D., Maiysha D. Jones, David R. Singleton, and Michael D. Aitken. 2012. "Long-Term Simulation of in Situ Biostimulation of Polycyclic Aromatic Hydrocarbon-Contaminated Soil." Biodegradation 23 (4): 621-33. doi:10.1007/s10532-012-9538-9.

Rodriguez-Escales, P., E. Borras, M. Sarra, and A. Folch. 2013. "Granulometry and Surfactants, Key Factors in Desorption and Biodegradation (T. Versicolor) of PAHs in Soil and Groundwater." Water Air and Soil Pollution 224 (2). doi:10.1007/s11270-012-1422-z.

Rust, Dwight, and Stephen Wildes. 2008. "Surfactant Soy Information". United Soybean Board. http://soynewuses.org/wp-content/uploads/pdf/Surfactants\%20MOS\%20$\% 20 J a n \% 202009$.pdf.

Seo, Jong-Su, Young-Soo Keum, and Qing X. Li. 2009. "Bacterial Degradation of Aromatic Compounds." Int J Environ Res Public Health 6 (1): 278-309. doi:10.3390/ijerph6010278.

Simi Valley, CA Weather. http://www.areavibes.com/simi+valley-ca/weather/.

Smith, Jennifer, Sophia Dore, Donald Pope, Talaat Balba, and Alan Weston. 2007. "Biodegradation of Weathered Oil in Soils with a Long History of TPH Contamination." In Proceedings of the Annual International Conference on Soils, Sediments, Water and Energy. Vol. 12. 28. http://scholarworks.umass.edu/soilproceedings/vol12/iss1/28.

Soeder, C. J., A. Papaderos, M. Kleespies, H. Kneifel, F. H. Haegel, and L. Webb. 1996. "Influence of Phytogenic Surfactants (quillaya Saponin and Soya Lecithin) on Bio-Elimination of Phenanthrene and Fluoranthene by Three Bacteria." Applied Microbiology and Biotechnology 44 (5): 654-59.

Steffen, K.T. 2003. "Degradation of Recalcitrant Bipolymers an Dpolycyclic Aromatic Hydrocarbons by Litter-Decomposing Basidiomycetous Fungi." Finland: University of Helsinki.

Takada, S., M. Nakamura, T. Matsueda, R. Kondo, and K. Sakai. 1996. "Degradation of Polychlorinated Dibenzo-P-Dioxins and Polychlorinated Dibenzofurans by the White Rot Fungus Phanerochaete Sordida YK-624." Applied and Environmental Microbiology 62 (12): 4323-28. 
Tiedje, JM, JF 3rd Quensen, J Chee-Sanford, JP Schimel, and SA Boyd. 1993. "Microbial Reductive Dechlorination of PCBs." Biodegradation 1993-1994 (4): $231-40$.

Tiehm, A., M. Stieber, P. Werner, and F. H. Frimmel. 1997a. "Surfactant-Enhanced Mobilization and Biodegradation of Polycyclic Aromatic Hydrocarbons in Manufactured Gas Plant Soil.” Environmental Science \& Technology 31 (9): 2570-76. doi:10.1021/es9609967.

- 1997b. "Surfactant-Enhanced Mobilization and Biodegradation of Polycyclic Aromatic Hydrocarbons in Manufactured Gas Plant Soil." Environmental Science \& Technology 31 (9): 2570-76. doi:10.1021/es9609967.

Tyagi, Meenu, M. Manuela R. da Fonseca, and Carla C. C. R. de Carvalho. 2011. "Bioaugmentation and Biostimulation Strategies to Improve the Effectiveness of Bioremediation Processes." Biodegradation 22 (2): 231-41. doi:10.1007/s10532010-9394-4.

Urbaniak, Magdalena. 2013. Biodegradation - Engineering and Technology. CC BY. http://www.intechopen.com/books/biodegradation-engineering-andtechnology/biodegradation-of-pcdds-pcdfs-and-pcbs.

US EPA, OSWER. 2013. "How To Evaluate Alternative Cleanup Technologies For Underground Storage Tank Sites: A Guide For Corrective Action Plan Reviewers". Policies \& Guidance. Accessed November 20. http://www.epa.gov/oust/pubs/tums.htm.

Van Hamme, J. D., A. Singh, and O. P. Ward. 2003. "Recent Advances in Petroleum Microbiology." Microbiology and Molecular Biology Reviews 67 (4): 503-+. doi:10.1128/MMBR.67.4.503-549.2003.

Viisimaa, Marika, Oleksandr Karpenko, Volodymyr Novikov, Marina Trapido, and Anna Goi. 2013. "Influence of Biosurfactant on Combined Chemical-Biological Treatment of PCB-Contaminated Soil." Chemical Engineering Journal 220 (March): 352-59. doi:10.1016/j.cej.2013.01.041.

Waller, A. S., R. Krajmalnik-Brown, F. E. Loffler, and E. A. Edwards. 2005. "Multiple Reductive-Dehalogenase-Homologous Genes Are Simultaneously Transcribed during Dechlorination by Dehalococcoides-Containing Cultures." Applied and Environmental Microbiology 71 (12): 8257-64. doi:10.1128/AEM.71.12.82578264.2005.

Whang, Liang-Ming, Pao-Wen G. Liu, Chih-Chung Ma, and Sheng-Shung Cheng. 2009. "Application of Rhamnolipid and Surfactin for Enhanced Diesel Biodegradation- 
Effects of $\mathrm{pH}$ and Ammonium Addition." Journal of Hazardous Materials 164 (23): 1045-50. doi:10.1016/j.jhazmat.2008.09.006.

Wilkes, H., R. M. Wittich, K. N. Timmis, P. Fortnagel, and W. Francke. 1996. "Degradation of Chlorinated Dibenzofurans and Dibenzo-P-Dioxins by Sphingomonas Sp Strain RW1.” Applied and Environmental Microbiology 62 (2): 367-71.

Wilson, S. C., R. E. Alcock, A. P. Sewart, and K. C. Jones. 1997. "Persistence of Organic Contaminants in Sewage Sludge-Amended Soil: A Field Experiment." Journal of Environmental Quality 26 (6): 1467-77.

Wittsiepe, J., Y. Kullmann, P. Schrey, F. Selenka, and M. Wilhelm. 2000. "Myeloperoxidase-Catalyzed Formation of PCDD/F from Chlorophenols." Chemosphere 40 (9-11): 963-68. doi:10.1016/S0045-6535(99)00340-9.

Yadav, J. S., H. Doddapaneni, and V. Subramanian. 2006. "P450ome of the White Rot Fungus Phanerochaete Chrysosporium: Structure, Evolution and Regulation of Expression of Genomic P450 Clusters.” Biochemical Society Transactions 34 (December): 1165-69.

Yakimov, M. M., K. N. Timmis, and P. N. Golyshin. 2007. “Obligate Oil-Degrading Marine Bacteria.” Current Opinion in Biotechnology 18 (3): 257-66.

Yong-lei, An, Lan-ying Zhang, Qiu Ming-ying, Ai-xia Zhou, Zhu Jin-rong, Zhang Lei, and Ren He-jun. 2011. "Screening of PCBs-Degrading Bacteria and Enhanced Bioremediation of Soil under Low-Temperature Condition." 2011 International Symposium on Water Resource and Environmental Protection (ISWREP), 145963. doi:10.1109/ISWREP.2011.5893300.

Yuan, S. Y., J. S. Chang, J. H. Yen, and B. V. Chang. 2001. "Biodegradation of Phenanthrene in River Sediment." Chemosphere 43 (3): 273-78. doi:10.1016/S0045-6535(00)00139-9.

Zeddel, A., A. Majcherczyk, and A. Huttermann. 1993. "Degradation of PolychlorinatedBiphenyls by White-Rot Fungi Pleurotus-Ostreatus and Trametes-Versicolor in a Solid-State System.” Toxicological and Environmental Chemistry 40 (1-4): 25566. doi:10.1080/02772249309357947. 


\section{APPENDICES}

Appendix A: Bar Graphs of EFH Equivalent Carbon Ranges

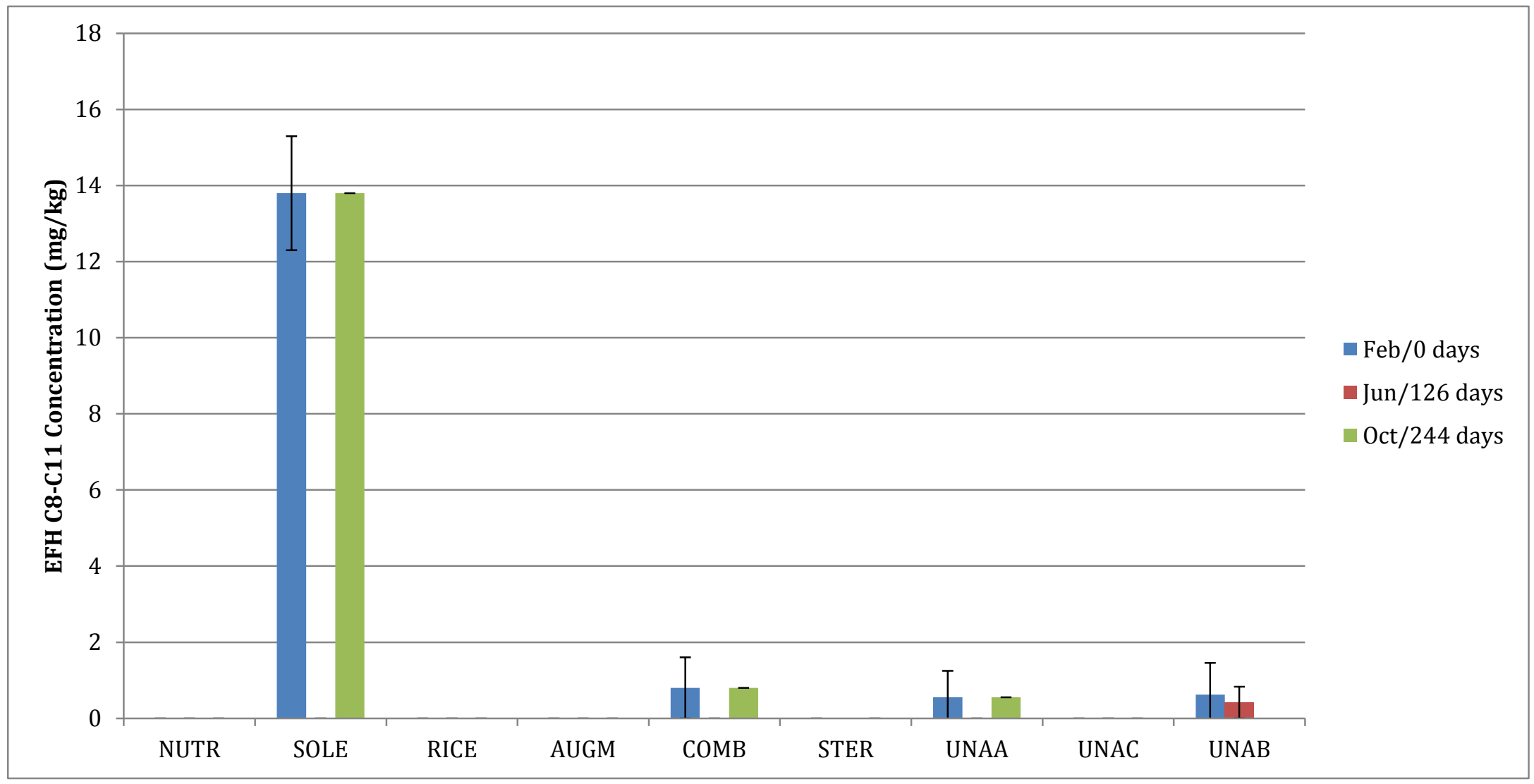

Figure 16: C8-C11 EFH equivalent carbon ranges during microcosm incubation 


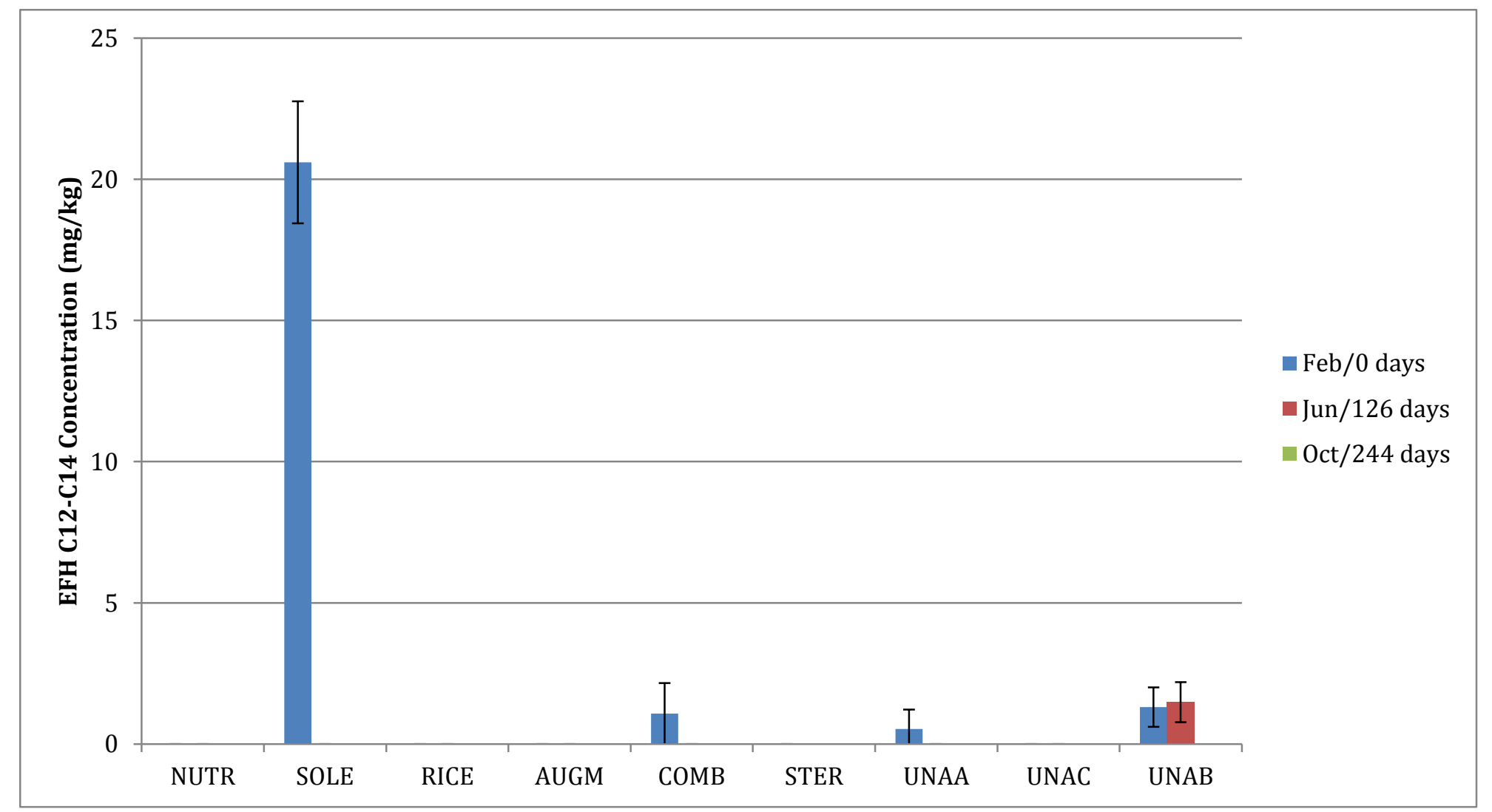

Figure 17: EFH C12-C14 concentrations during microcosm incubation 


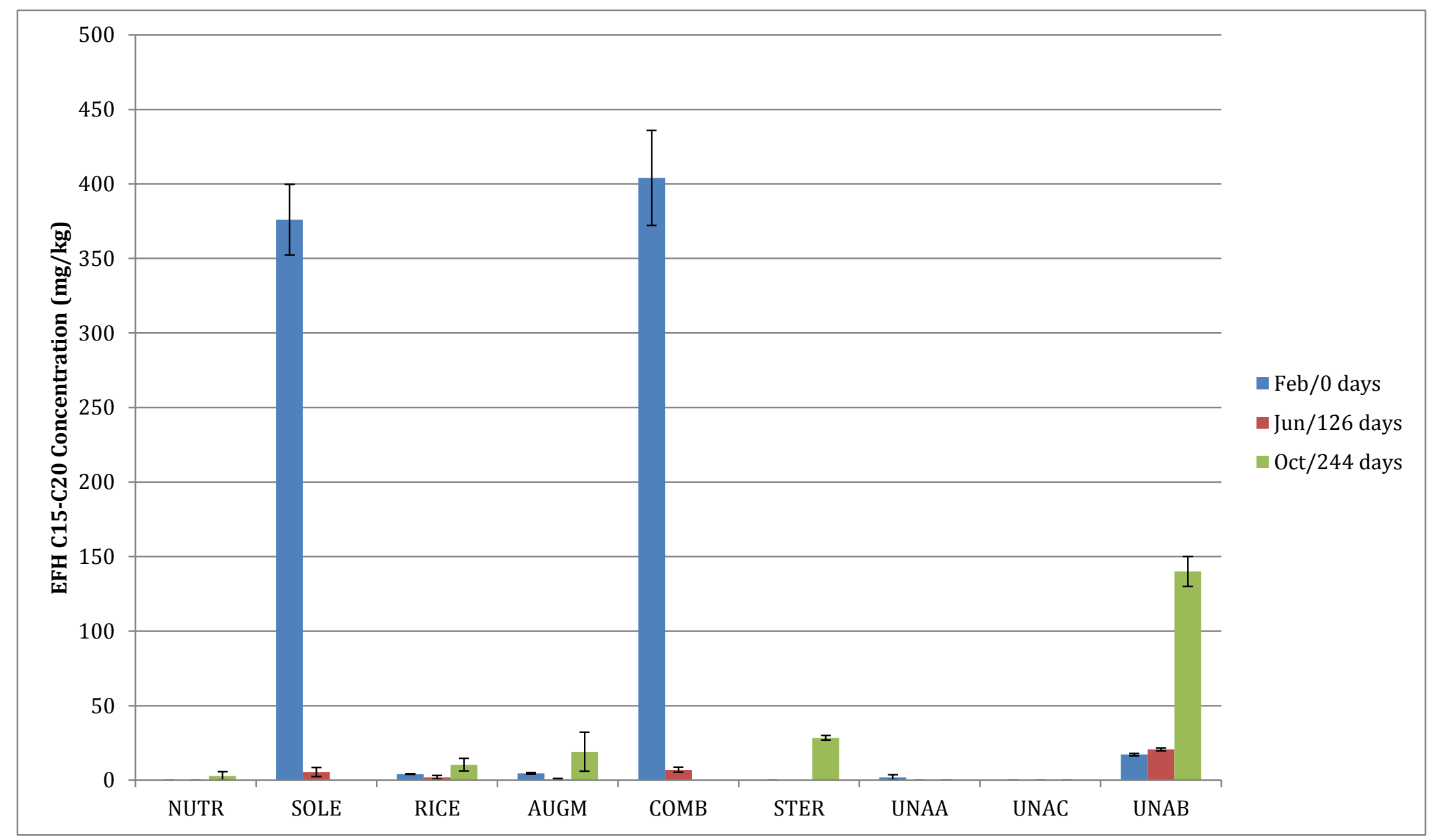

Figure 18: EFH C15-C20 concentrations during microcosm incubation 


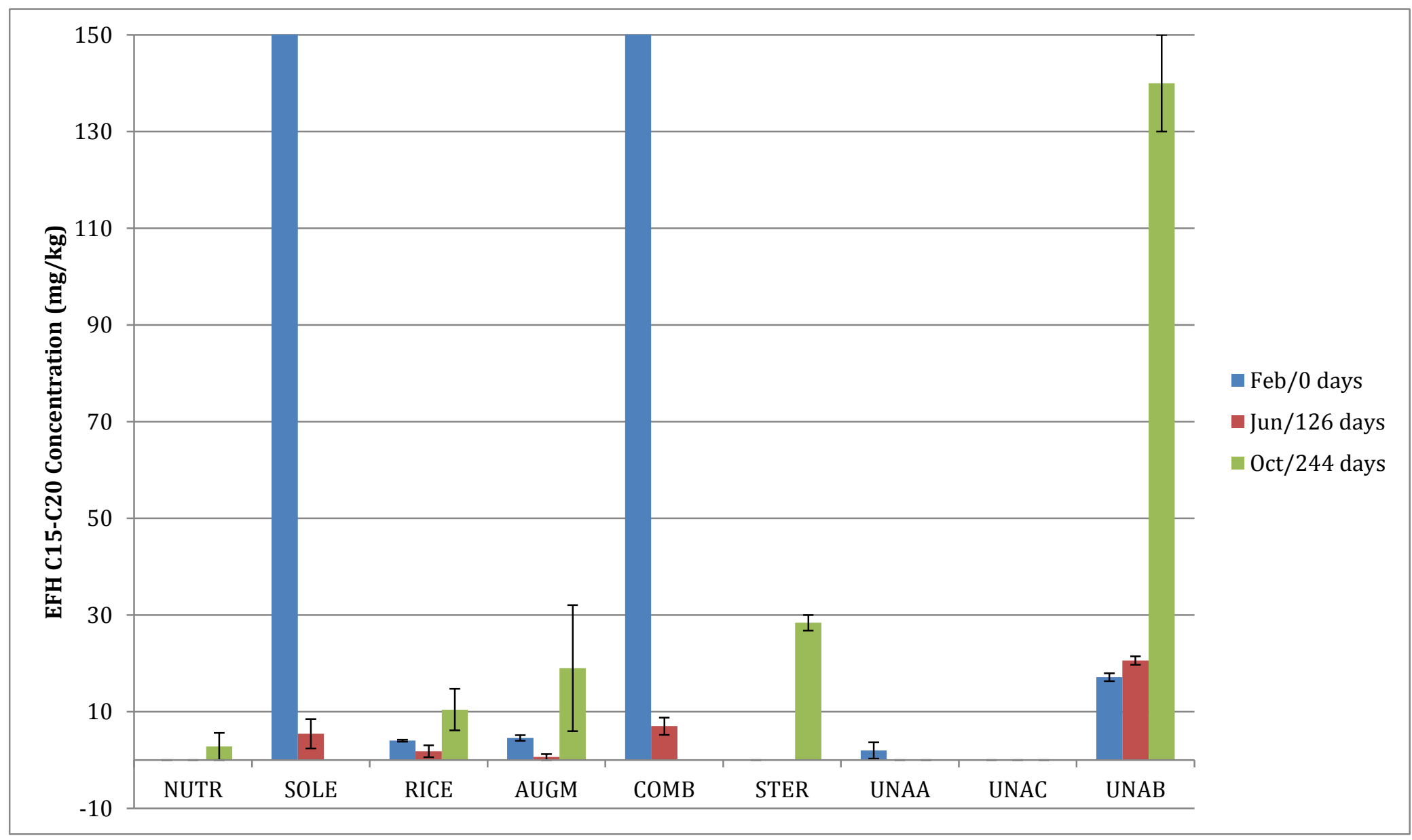

Figure 19: Truncated EFH C15-C20 concentrations during microcosm incubation 


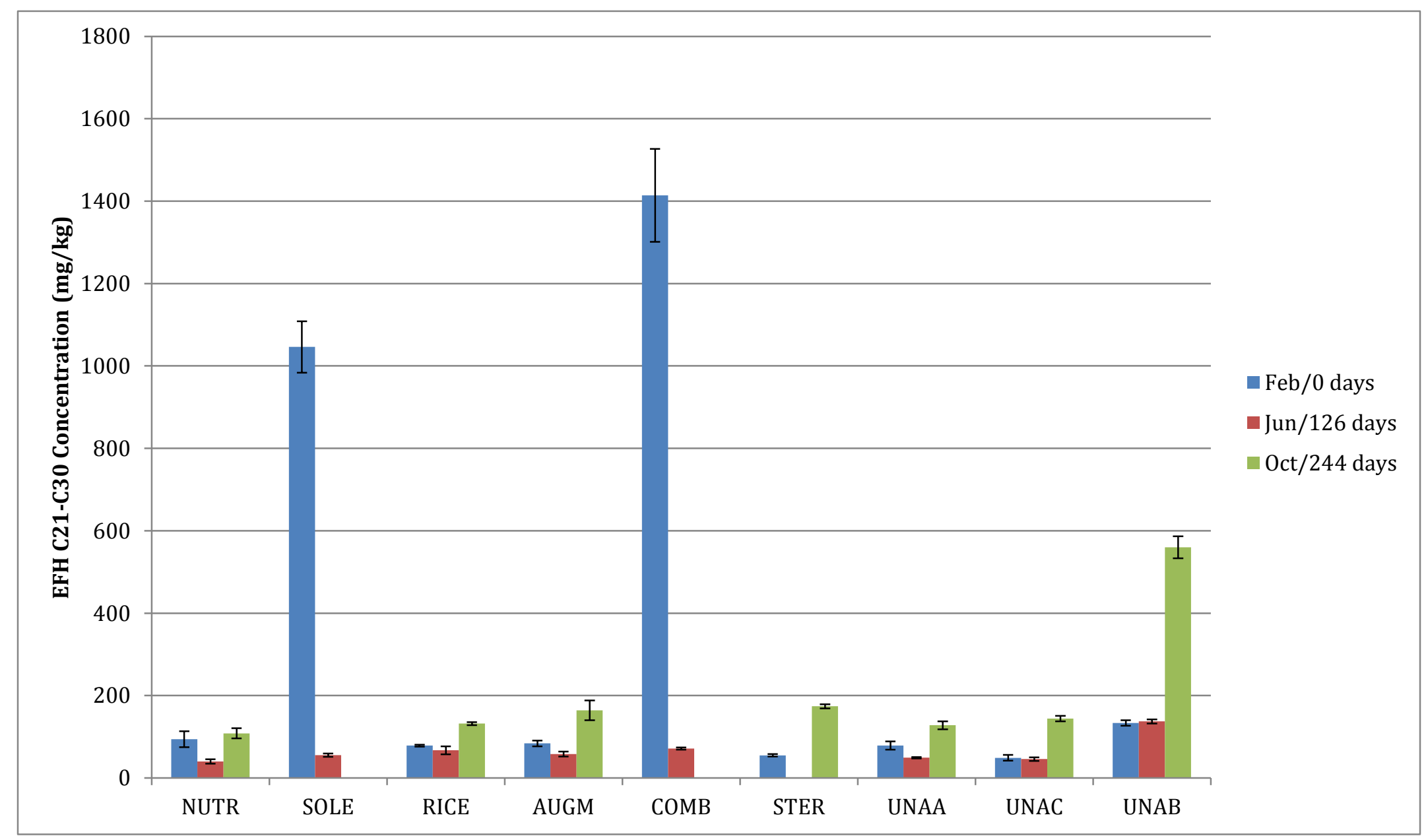

Figure 20: EFH C21-C30 concentrations during microcosm incubation 


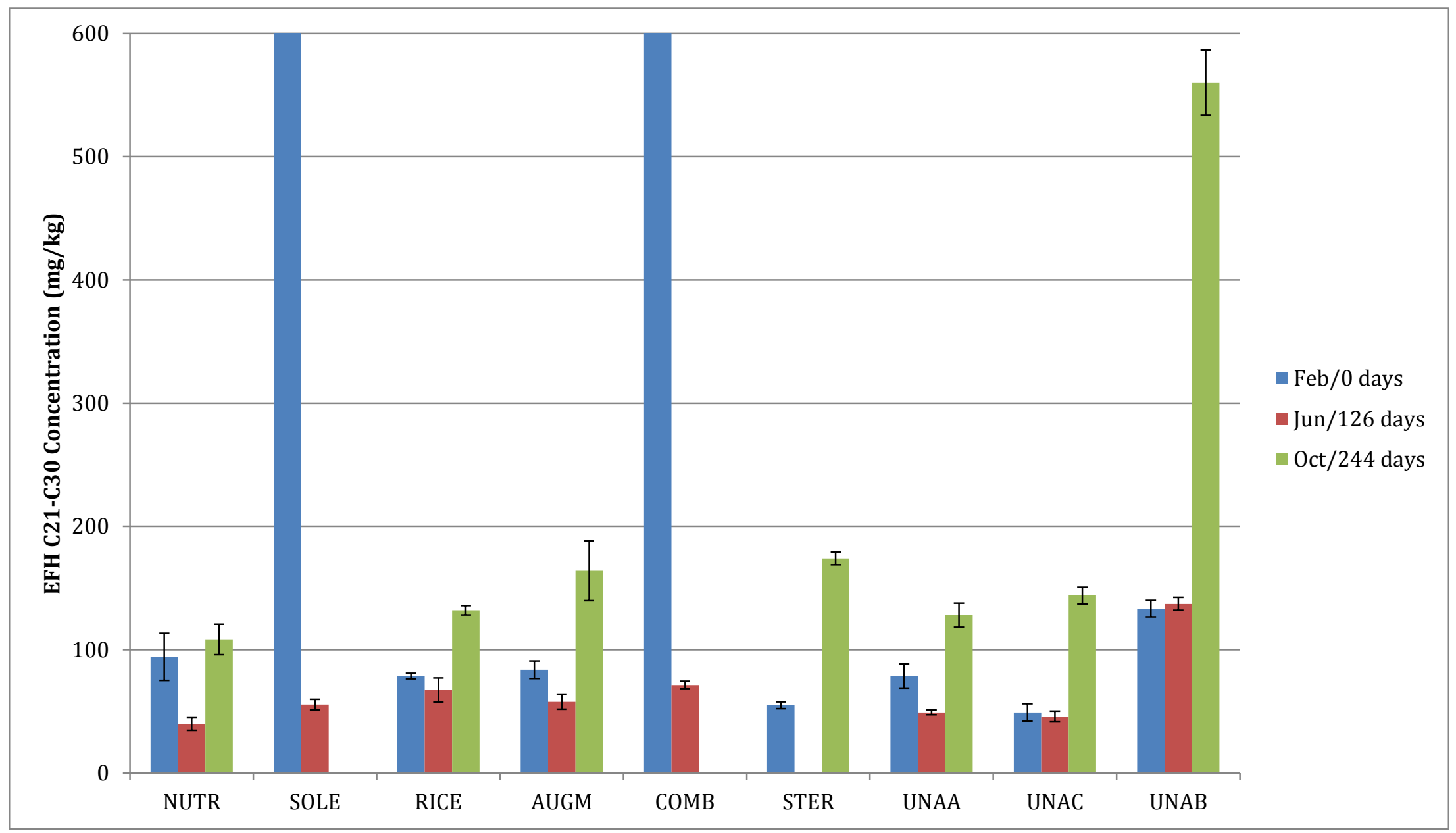

Figure 21: Truncated EFH C21-C30 concentrations during microcoms incubation 


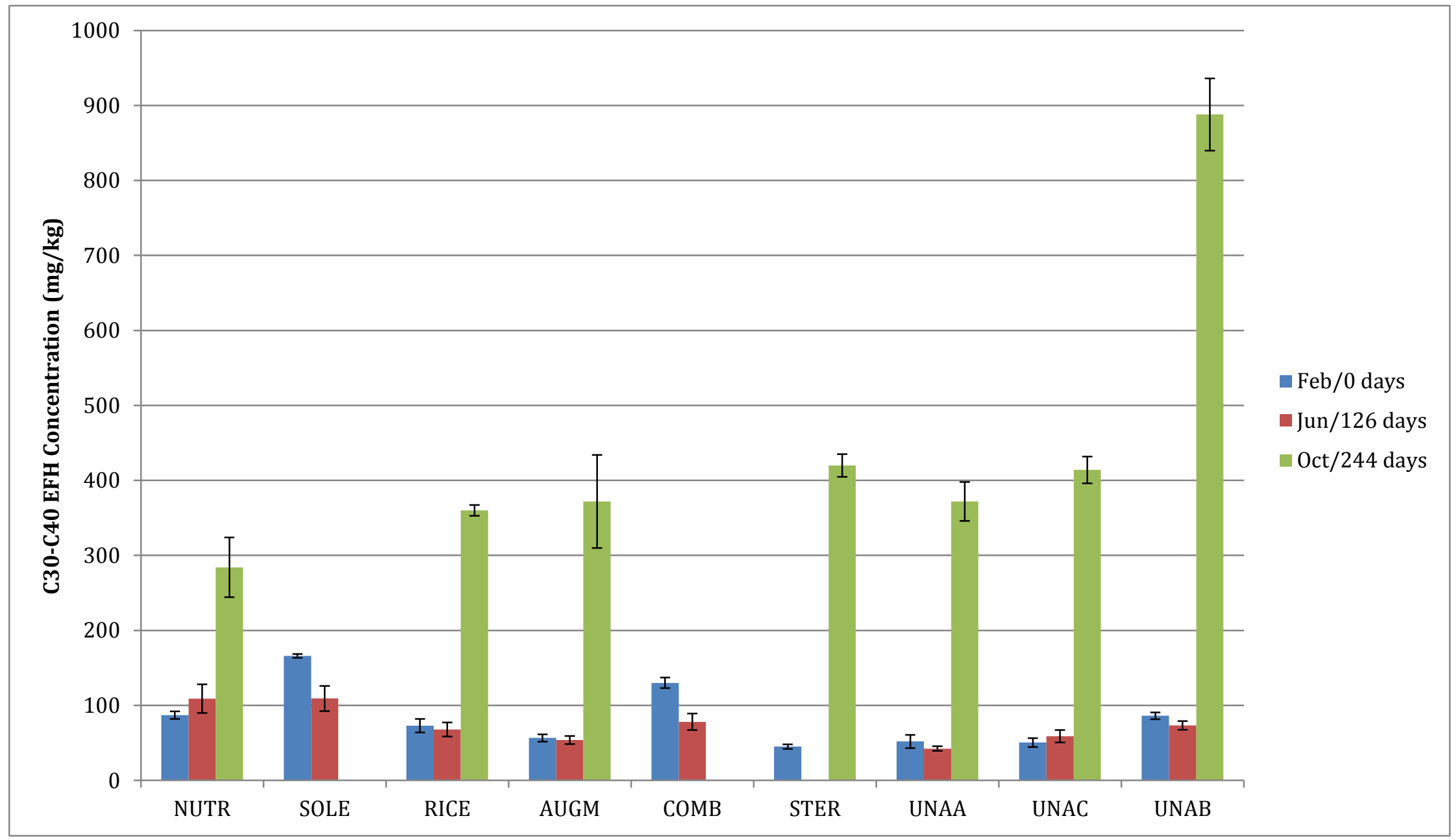

Figure 22: EFH C30-C40 concentrations during microcosm incubation 
Appendix B: Bar Graphs of Individual Dioxin Congener Concentrations

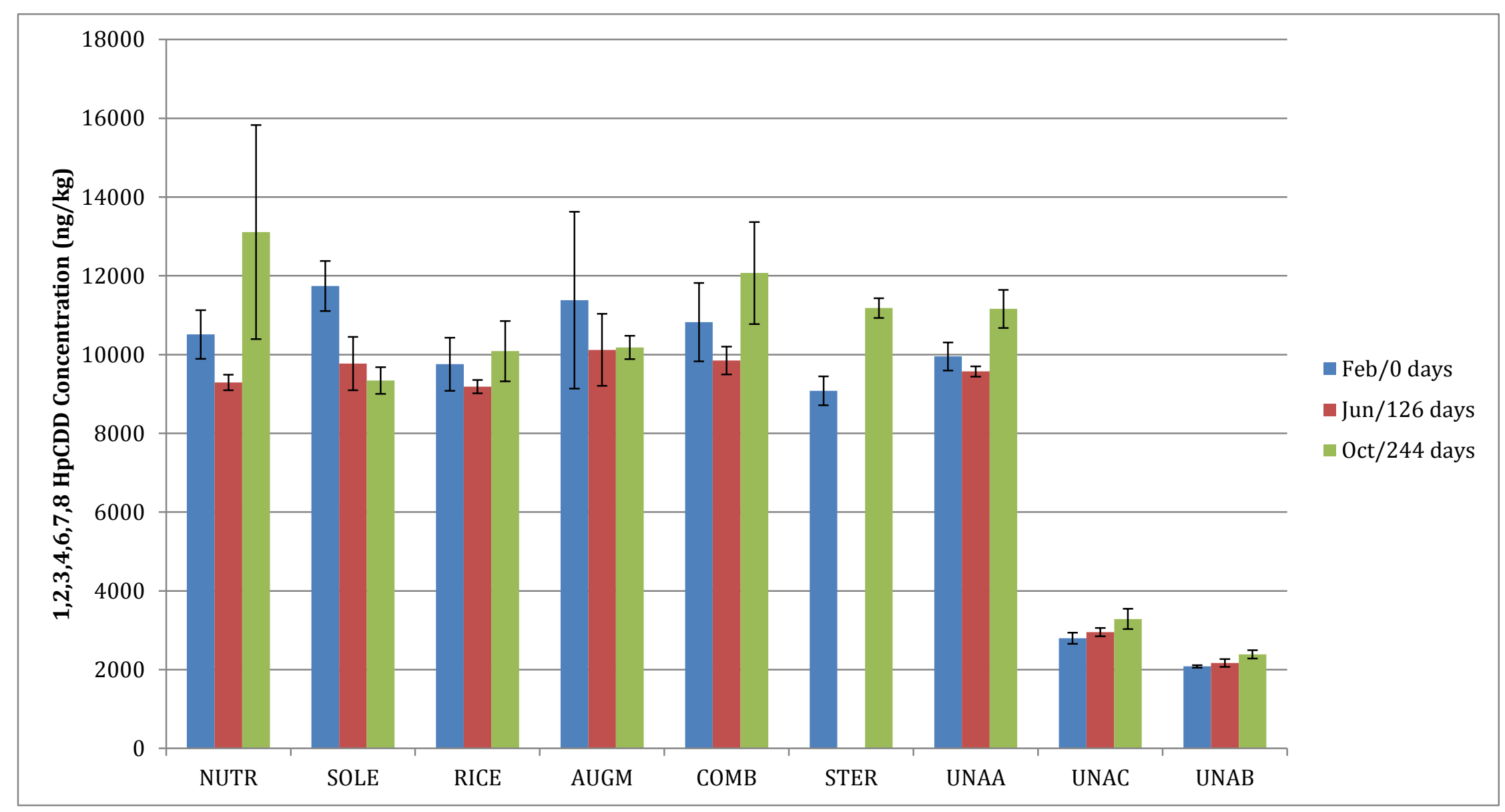

Figure 23: 1,2,3,4,6,7,8 HpCDD concentrations during microcosm incubation 


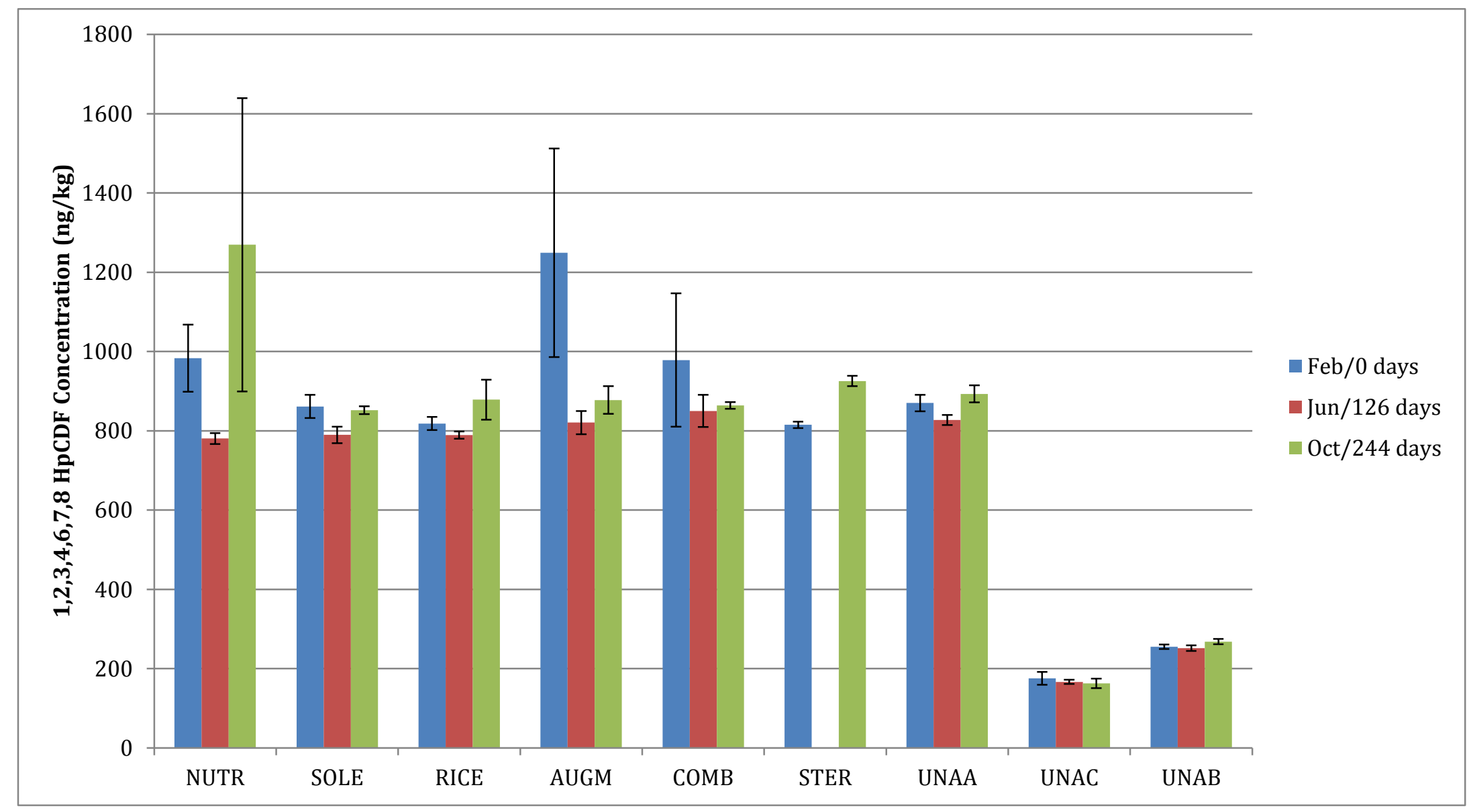

Figure 24: 1,2,3,4,6,7,8 HpCDF concentrations during microcosm incubation 


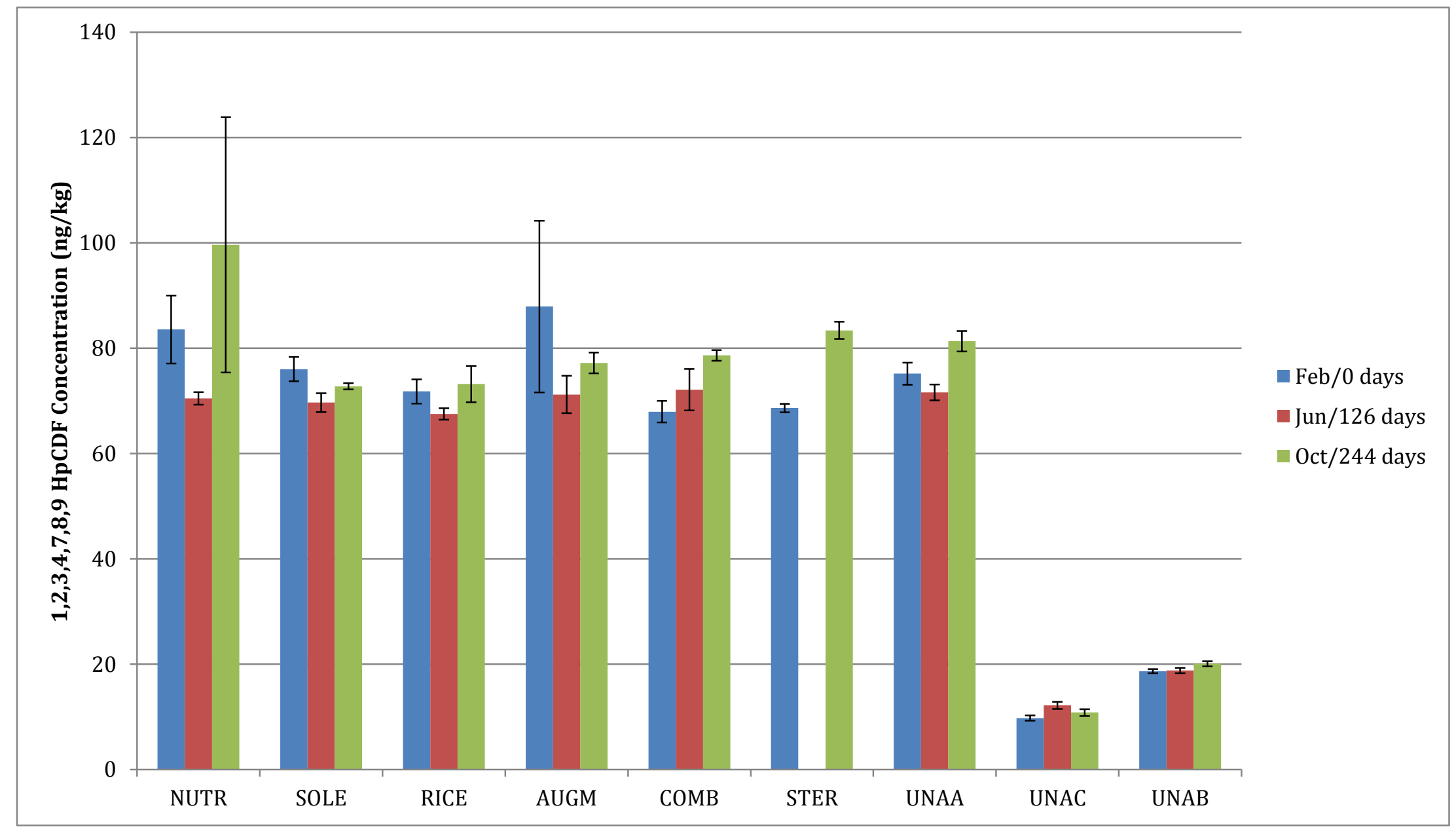

Figure 25: 1,2,3,4,7,8,9 HpCDF concentrations during microcosm incubation 


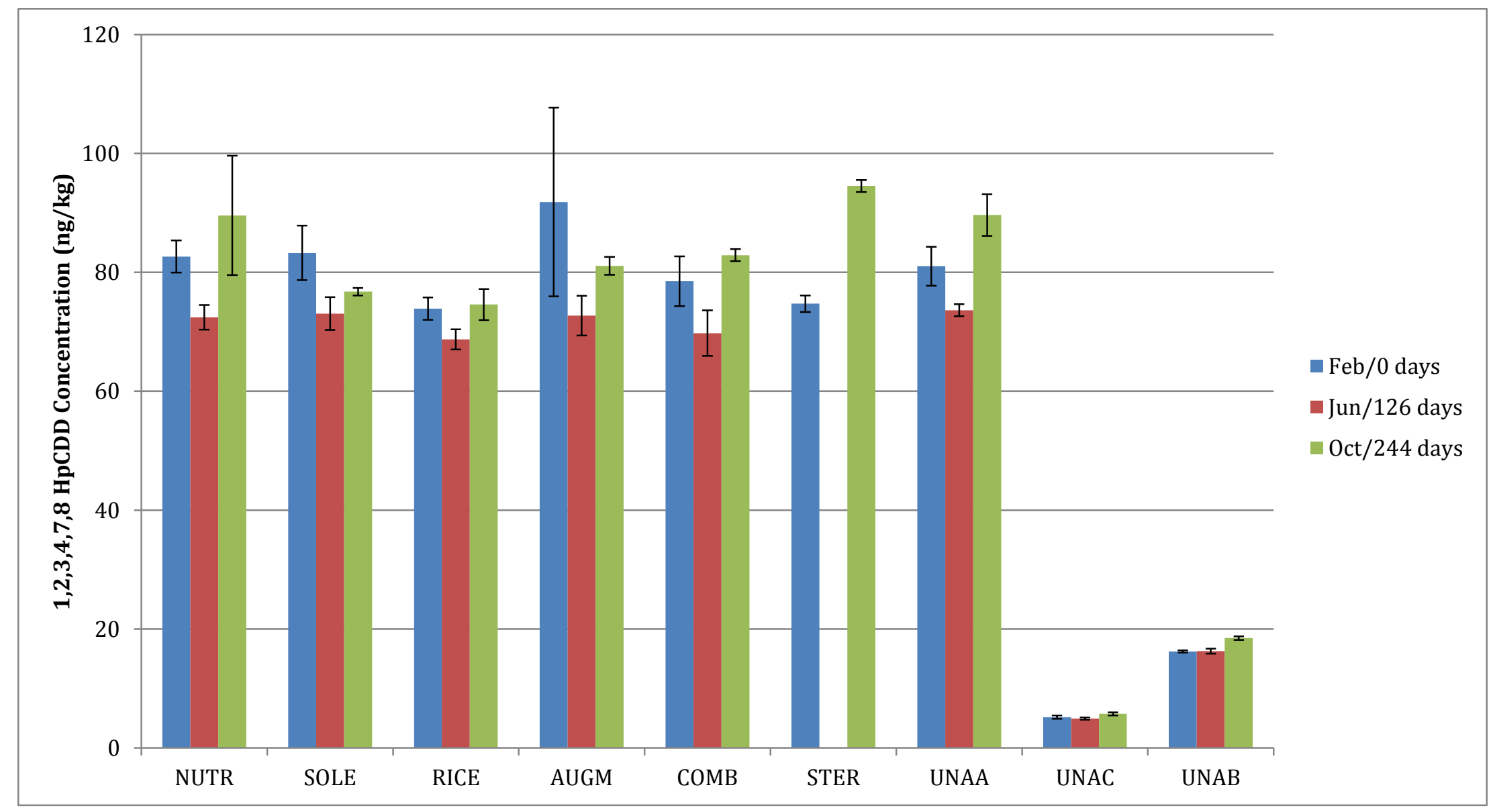

Figure 26: 1,2,3,4,7,8 HpCDD concentrations during microcosm incubation 


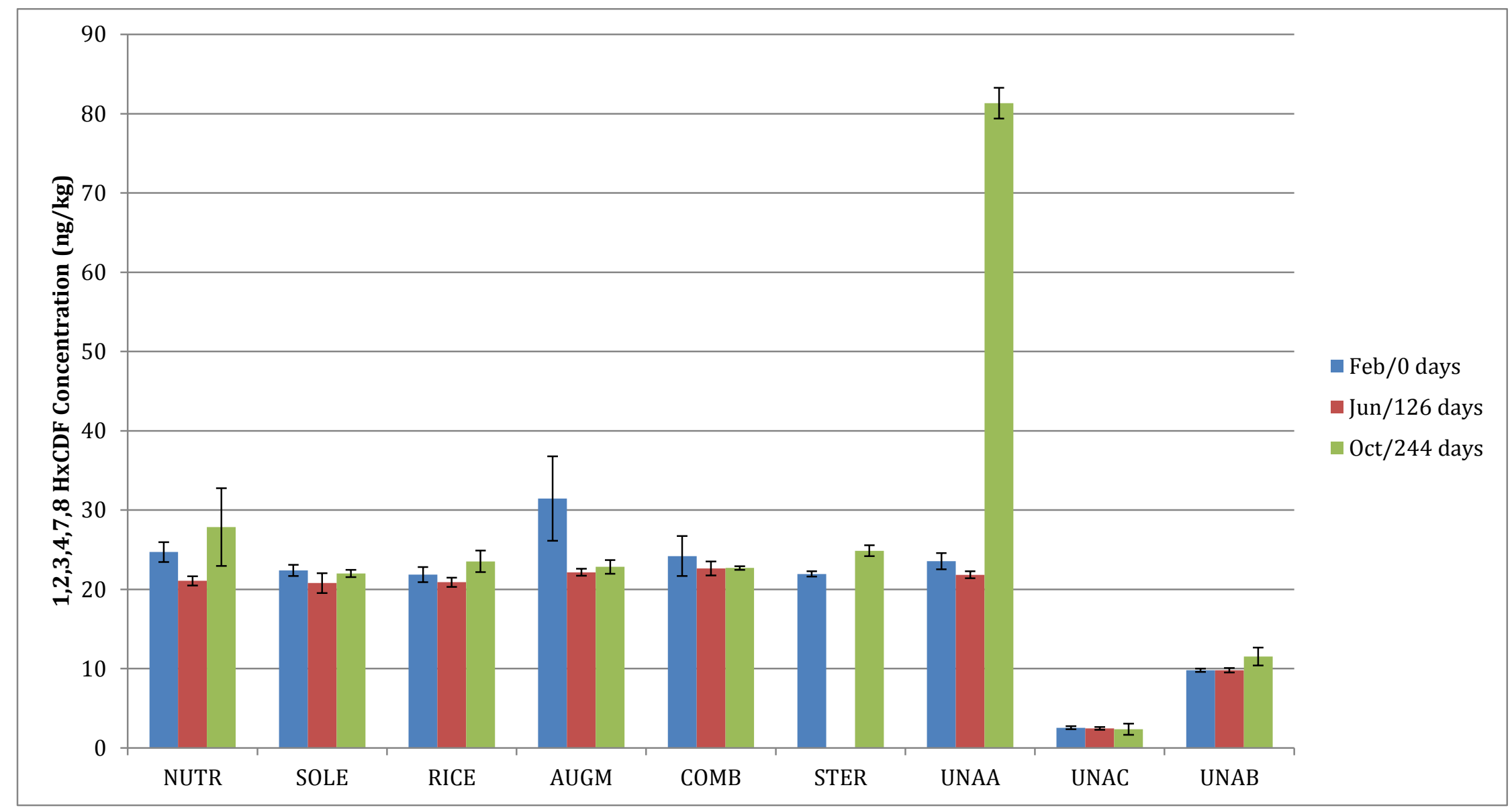

Figure 27: 1,2,3,4,7,8 HxCDF concentrations during microcosm incubation 


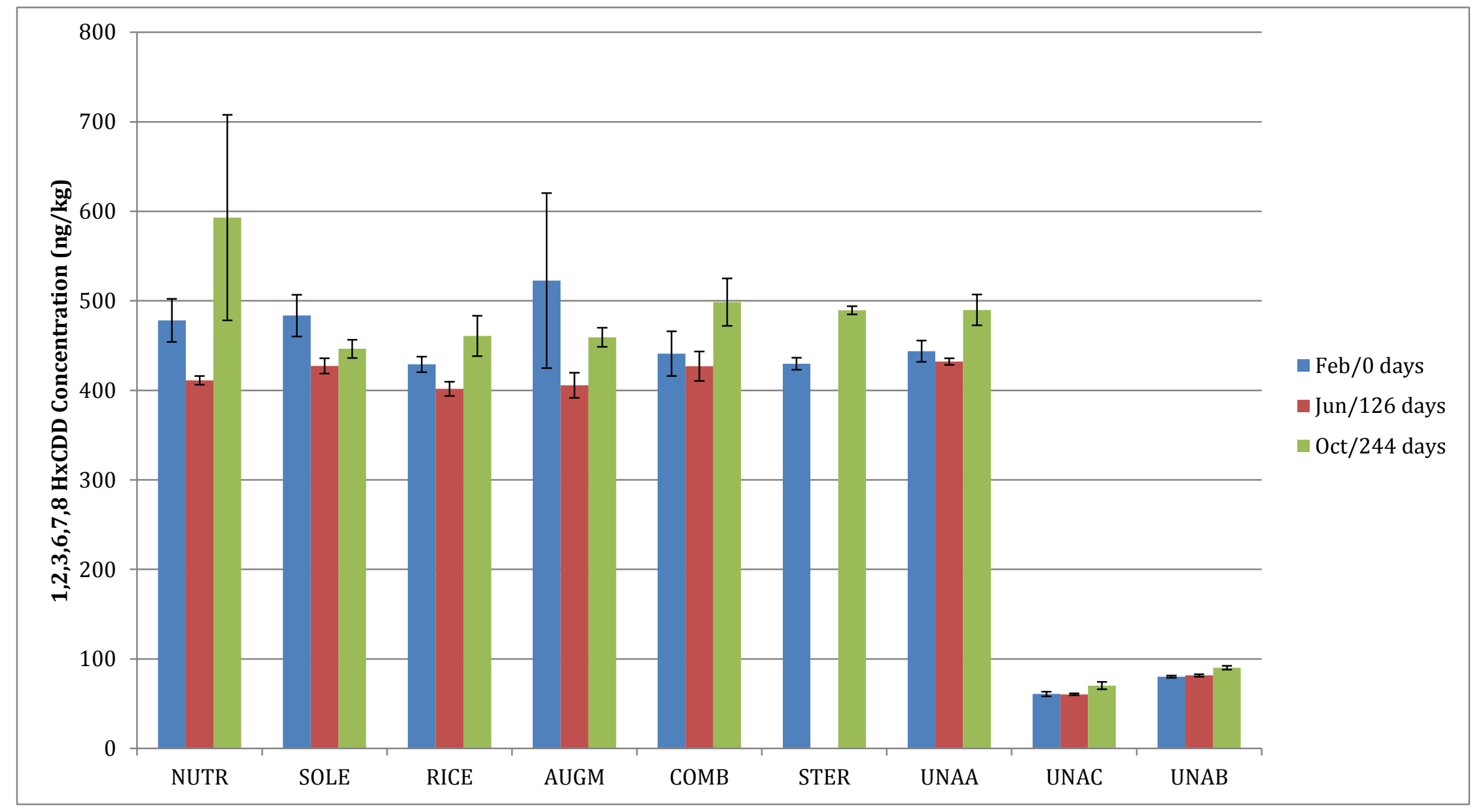

Figure 28: 1,2,3,6,7,8 HxCDD concentrations during microcosm incubation 


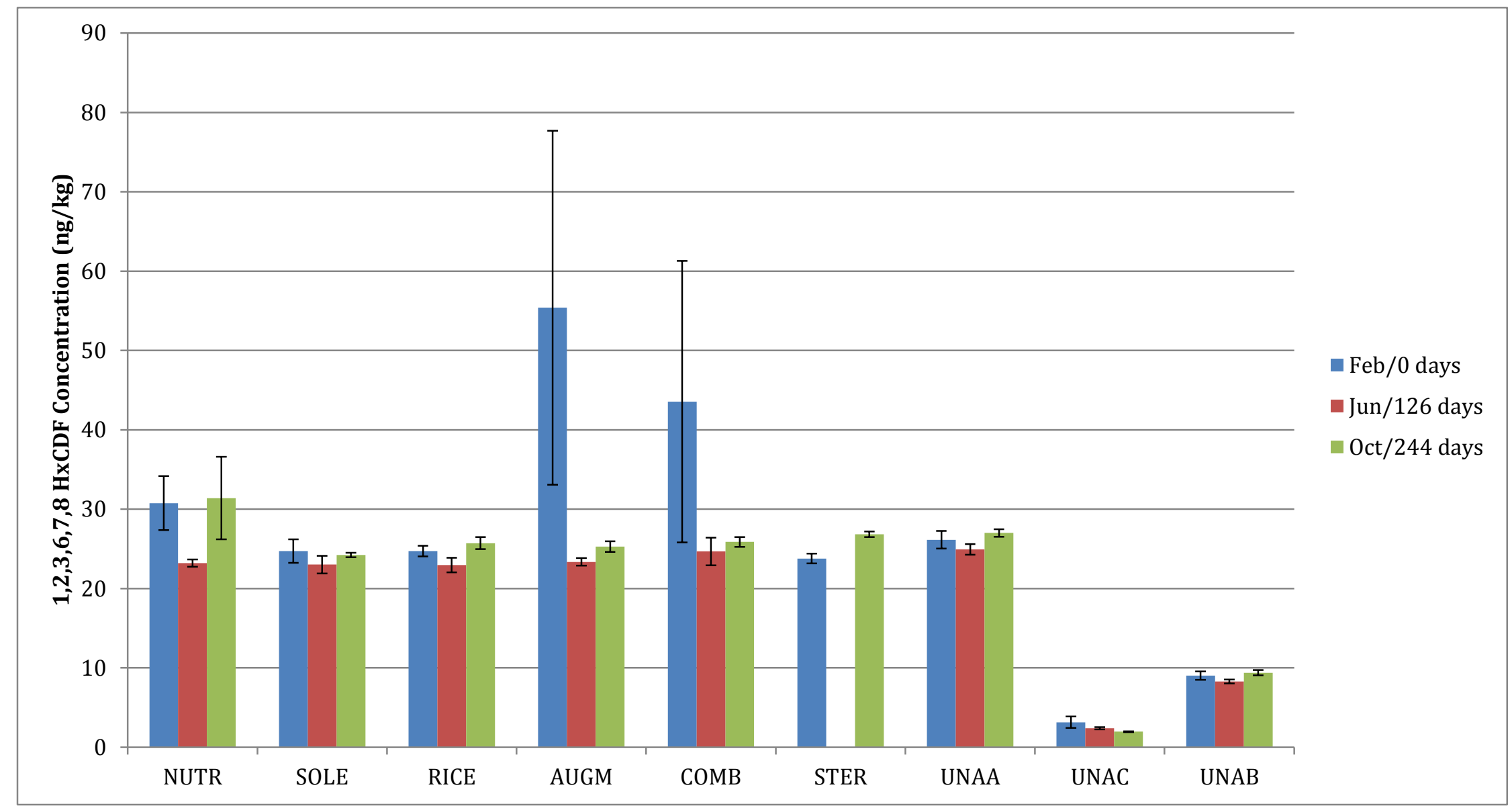

Figure 29: 1,2,3,6,7,8 HxCDF concentrations during microcosm incubation 


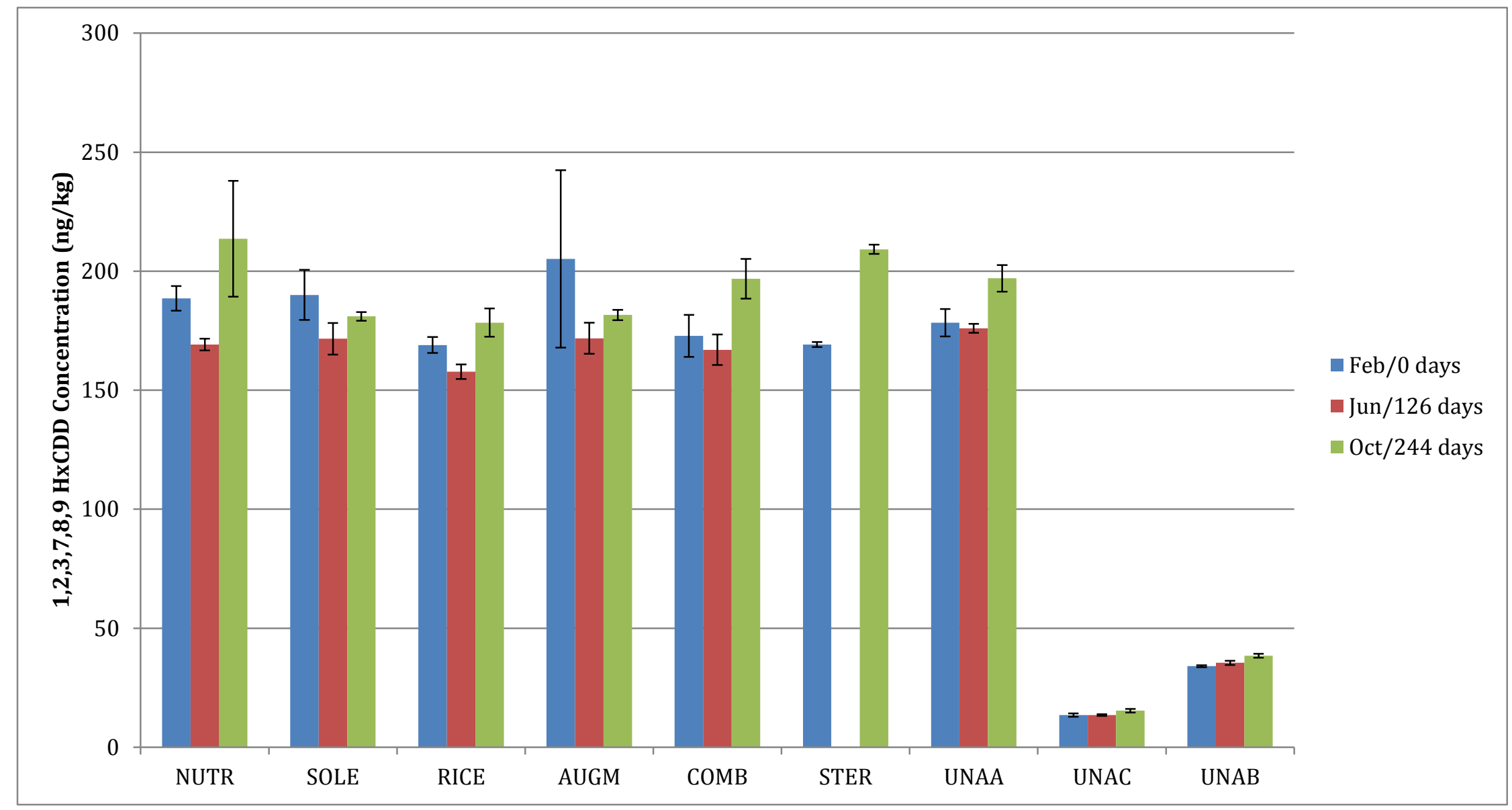

Figure 30: 1,2,3,7,8,9 HxCDD concentrations during microcosm incubation 


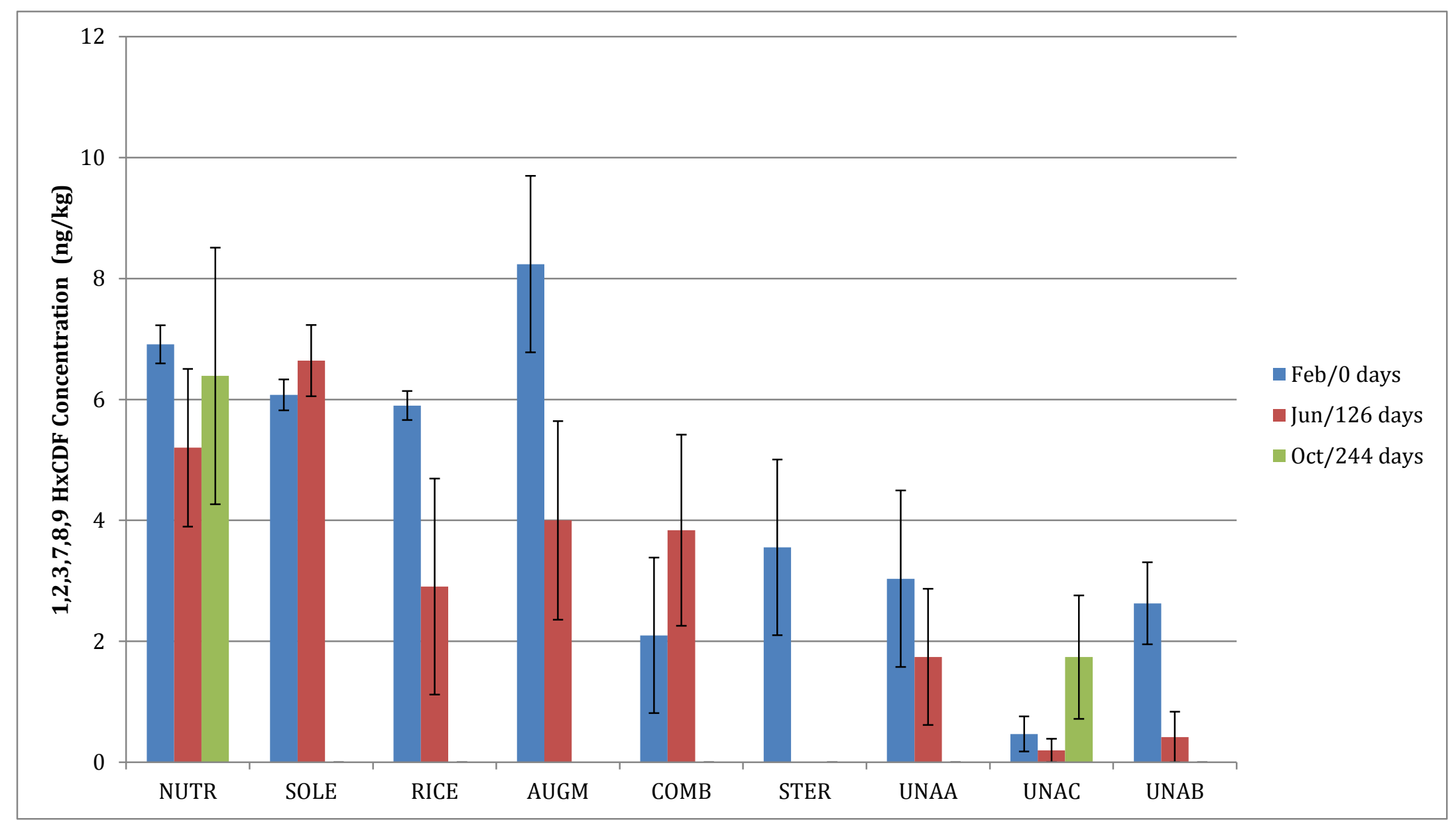

Figure 31: 1,2,3,7,8,9 HxCDF concentrations during microcosm incubation 


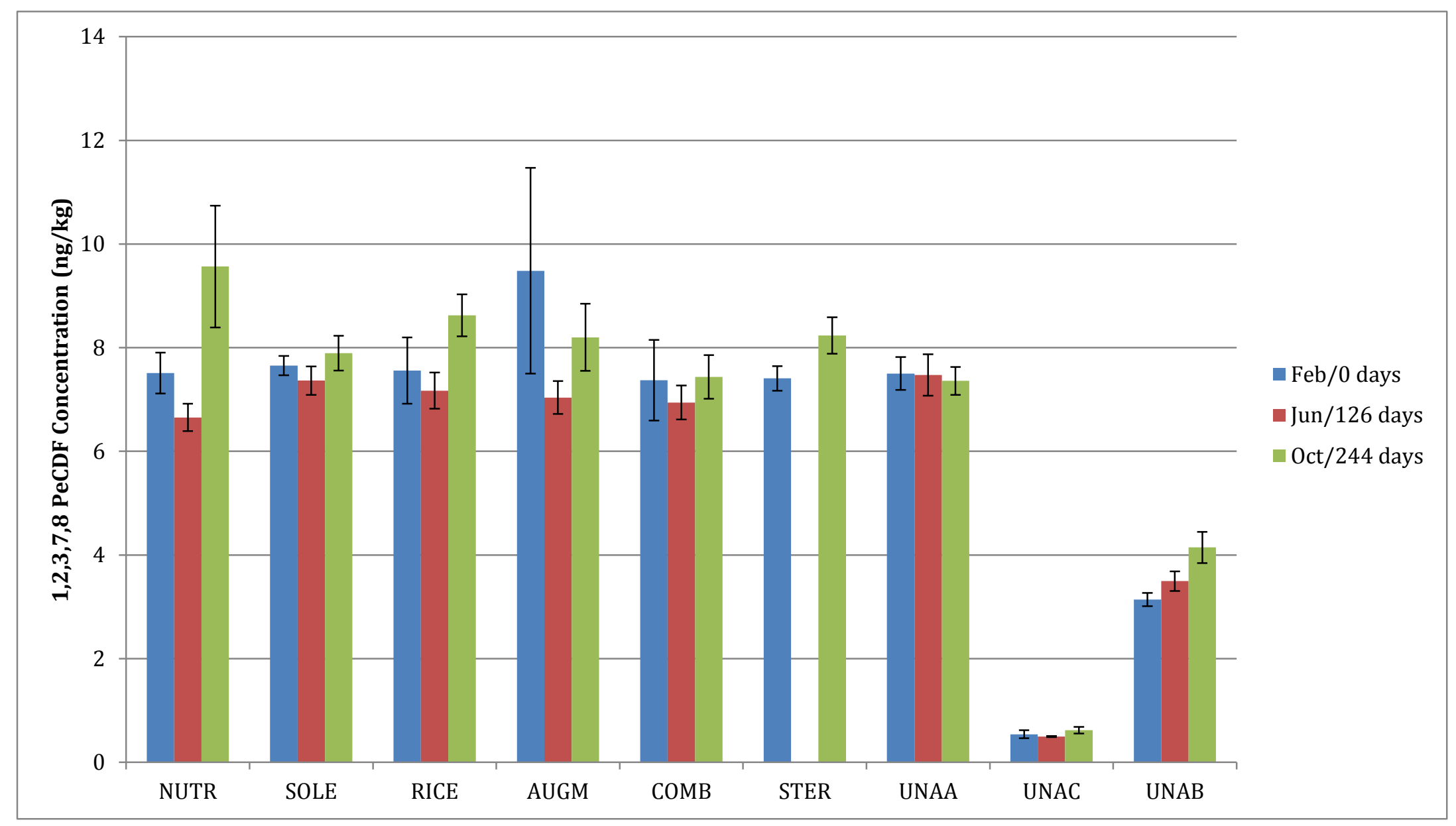

Figure 32: 1,2,3,7,8 PeCDF concentrations during microcosm incubation 


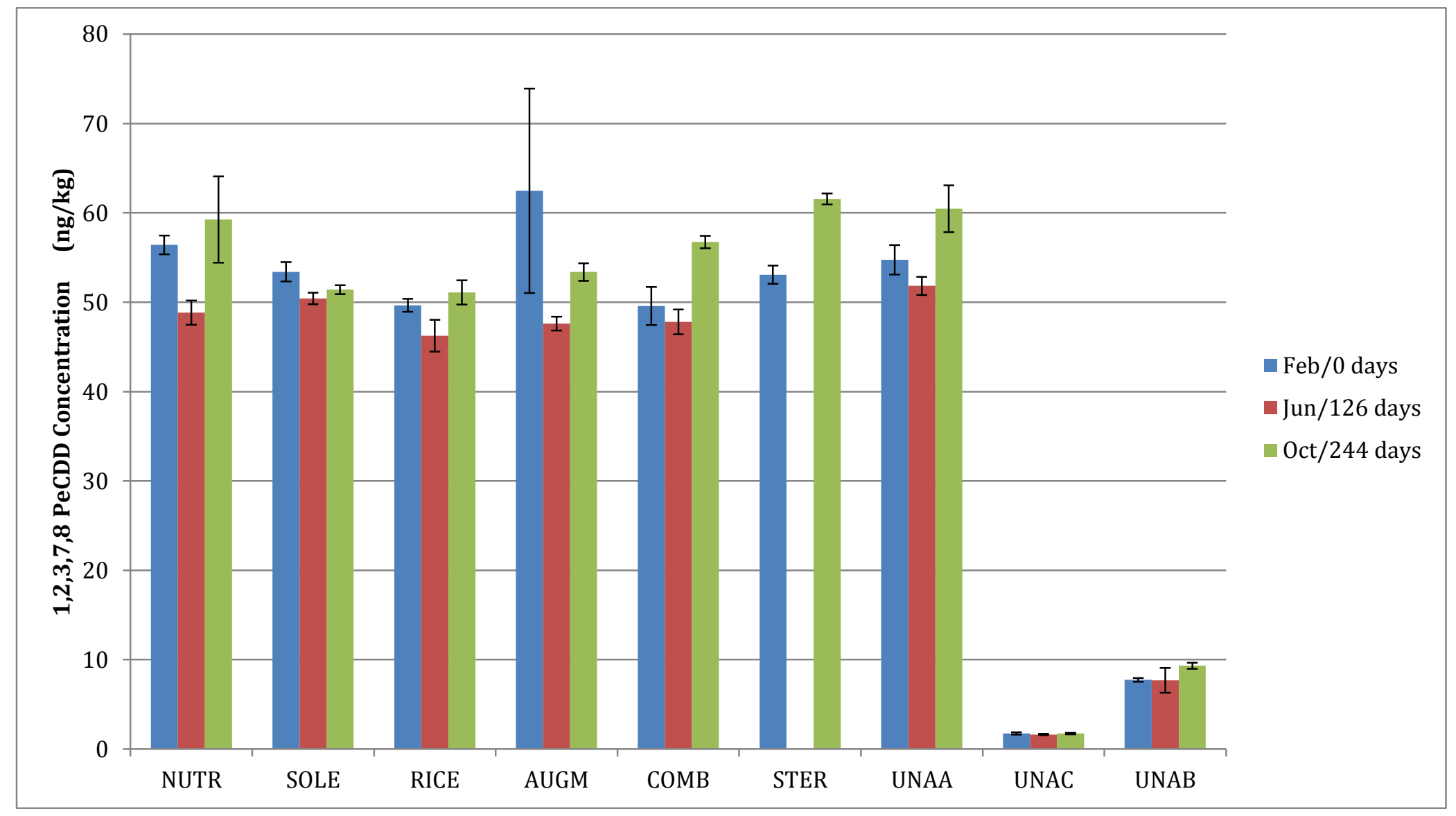

Figure 33: 1,2,3,7,8 PeCDD concentrations during microcosm incubation 


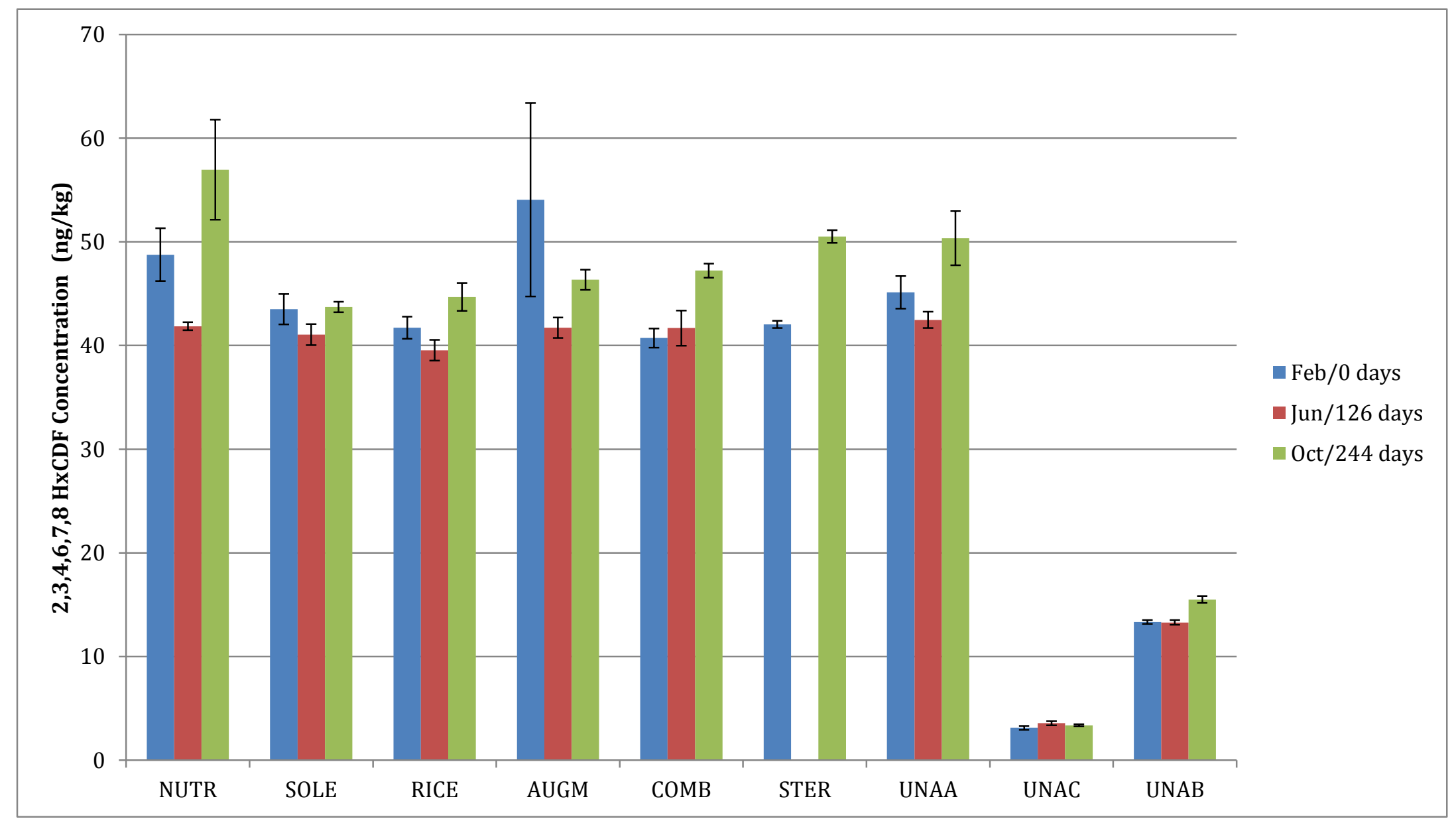

Figure 34: 2,3,4,6,7,8 HxCDF concentrations during microcosm incubation 


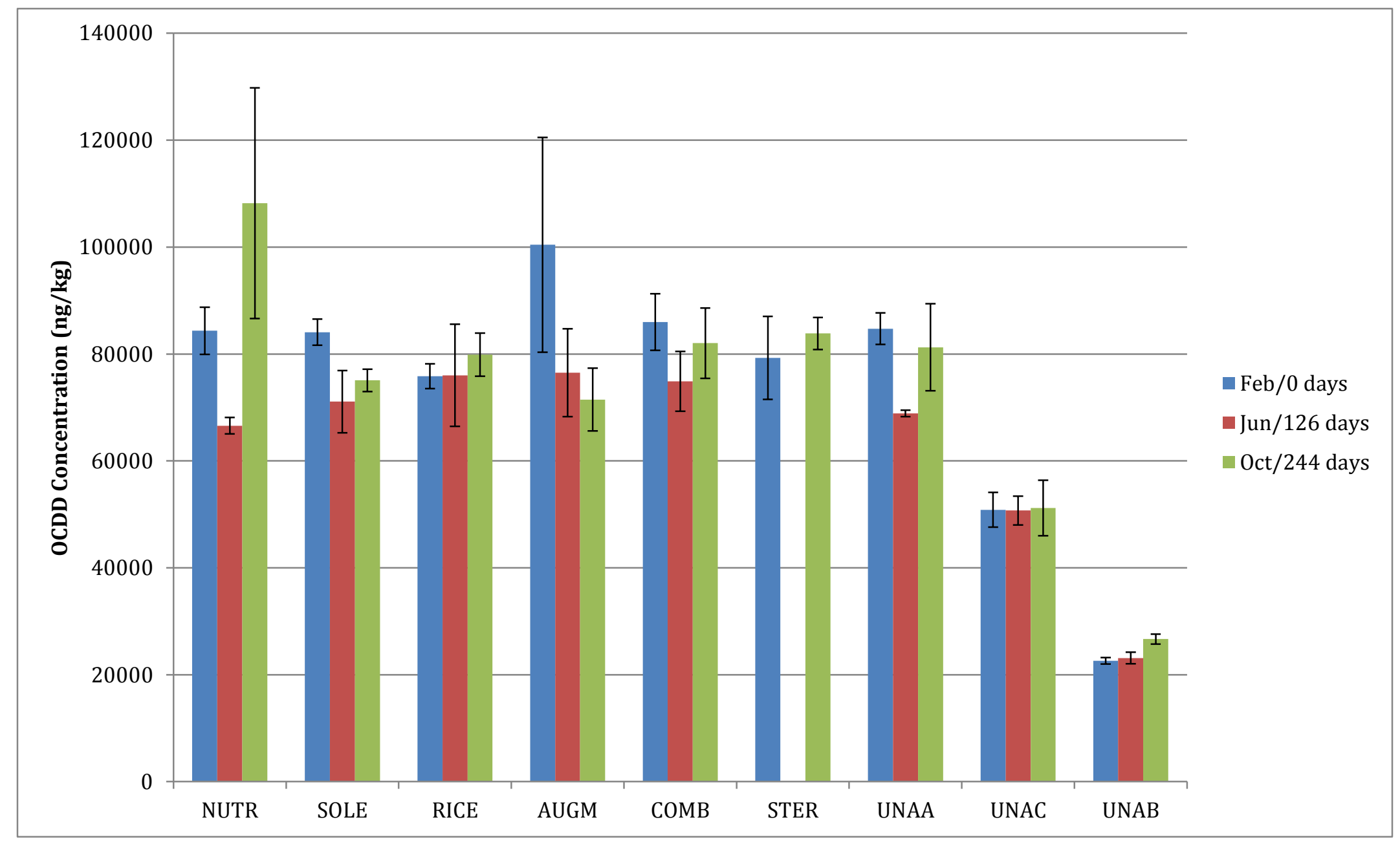

Figure 35: OCDD concentrations during microcosm incubation 


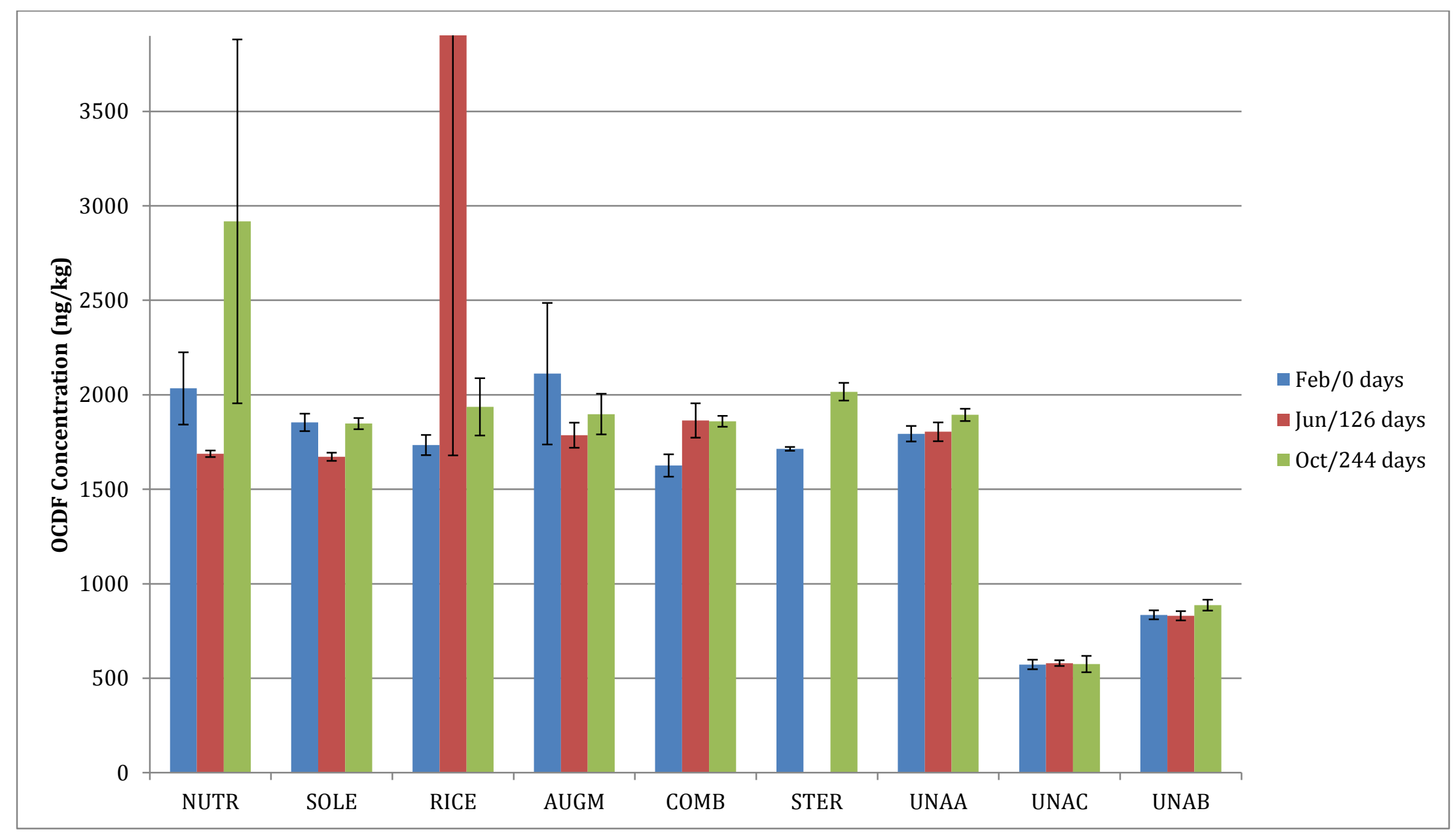

Figure 36: Truncated OCDF concentrations during microcosm incubation 
Appendix C: Bar Graphs of Individual PAH Compound Concentrations

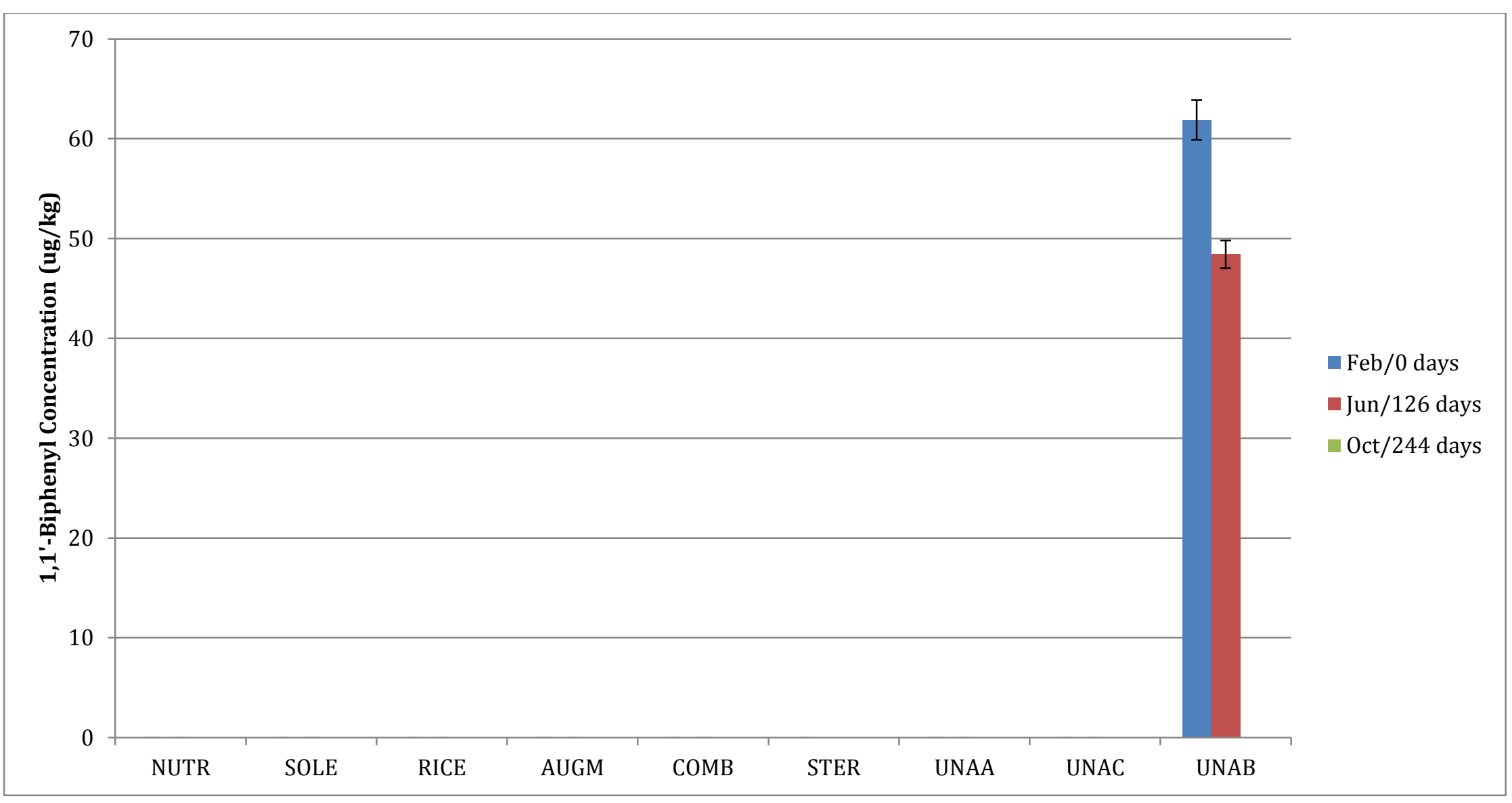

Figure 37: 1,1'-biphenyl concetrations during microcosm incubation 


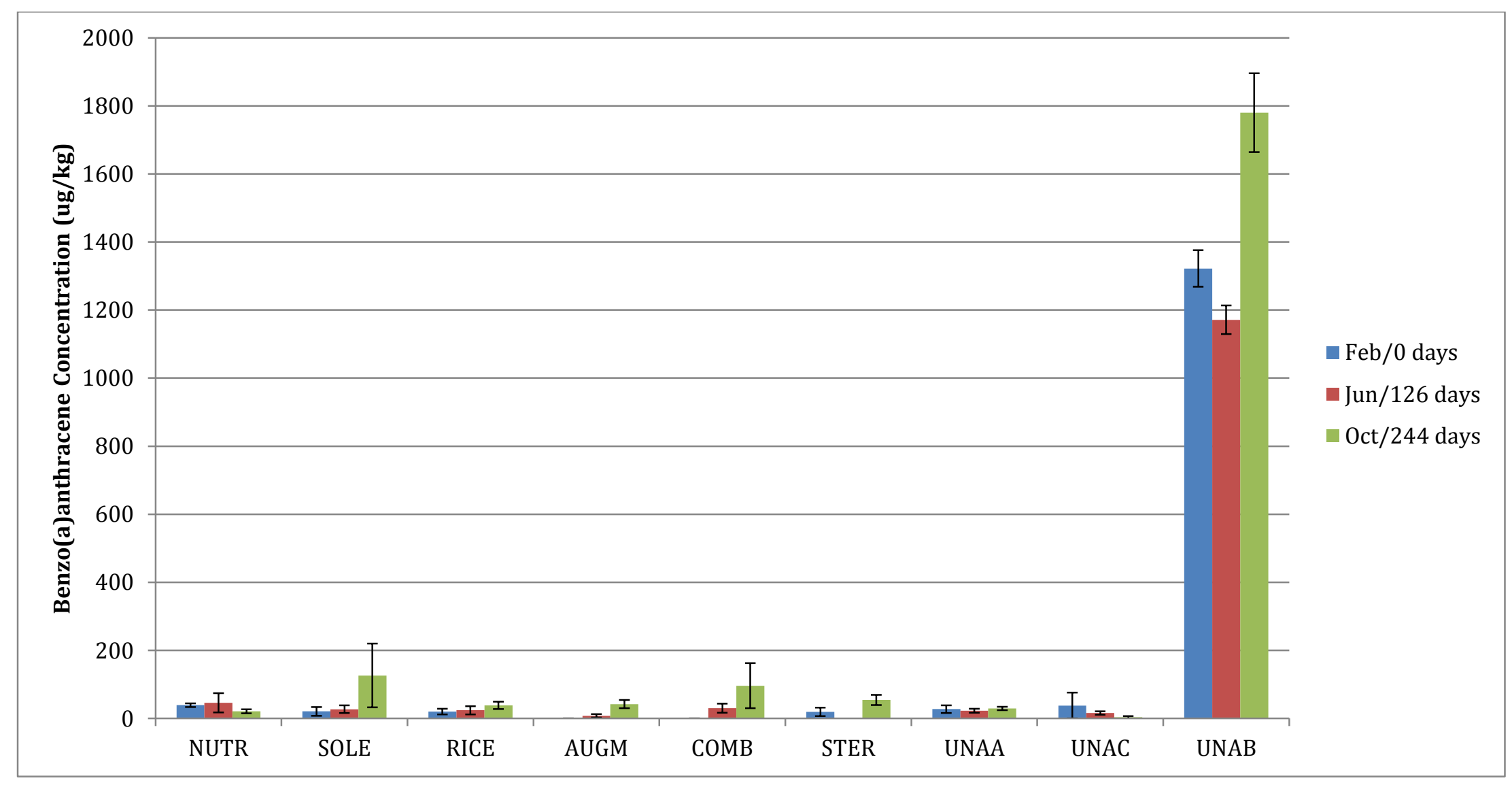

Figure 38: Benzo(a)anthracene concentrations during microcosm incubation (all soils) 


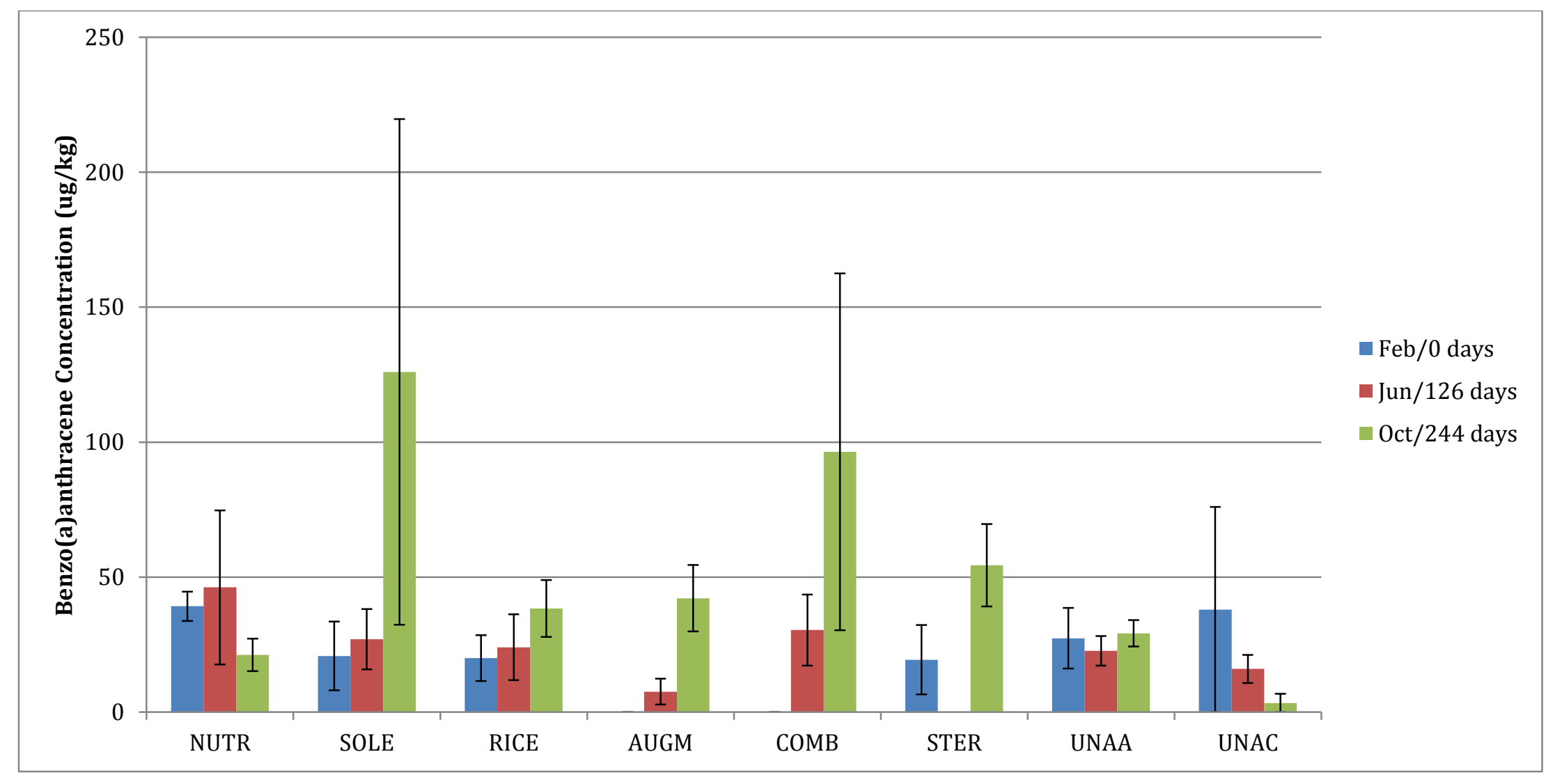

Figure 39: Benzo(a)anthracene during incubation (A and C) 


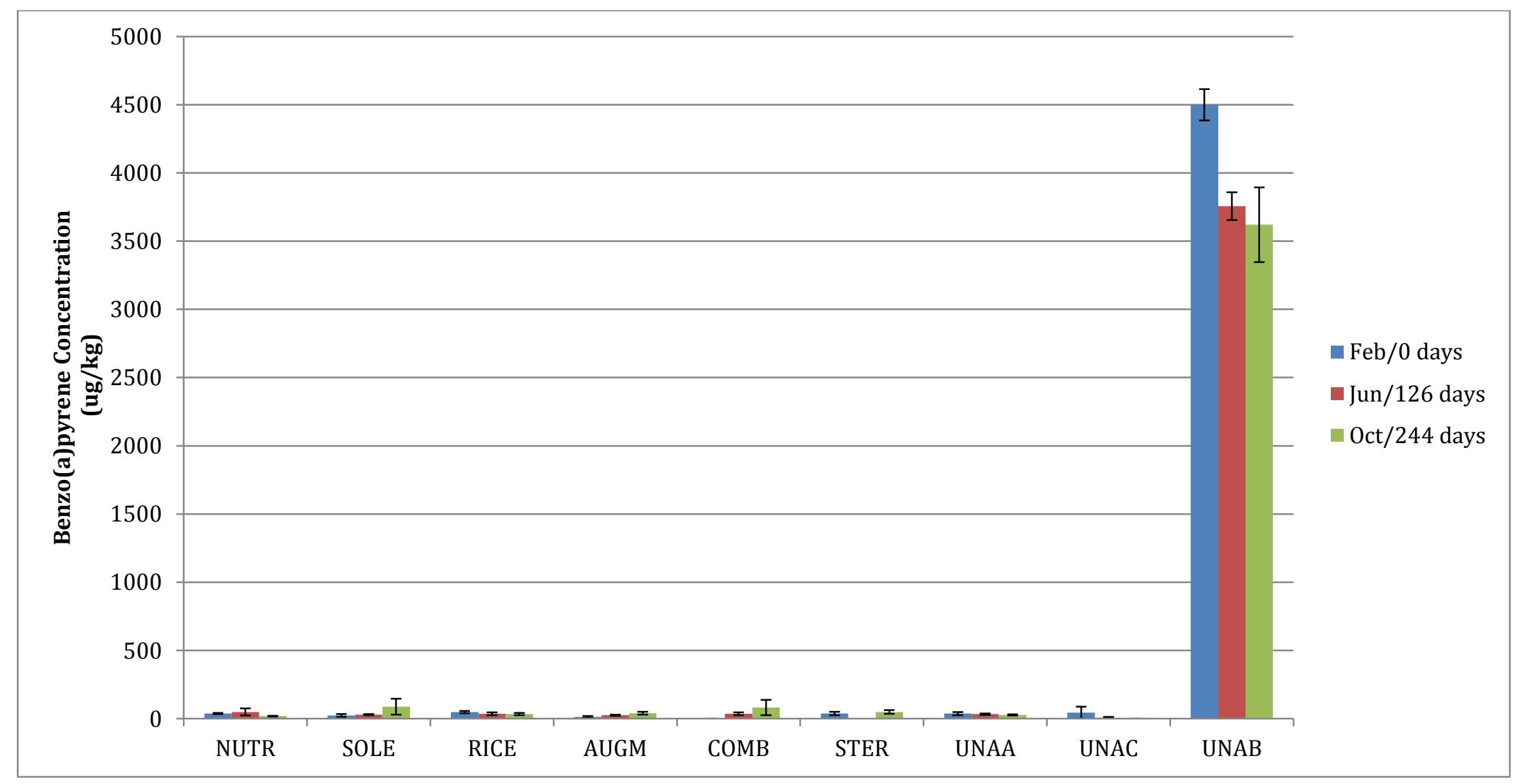

Figure 40: Benzo(a)pyrene concentrations during microcosm incubation (all soils) 


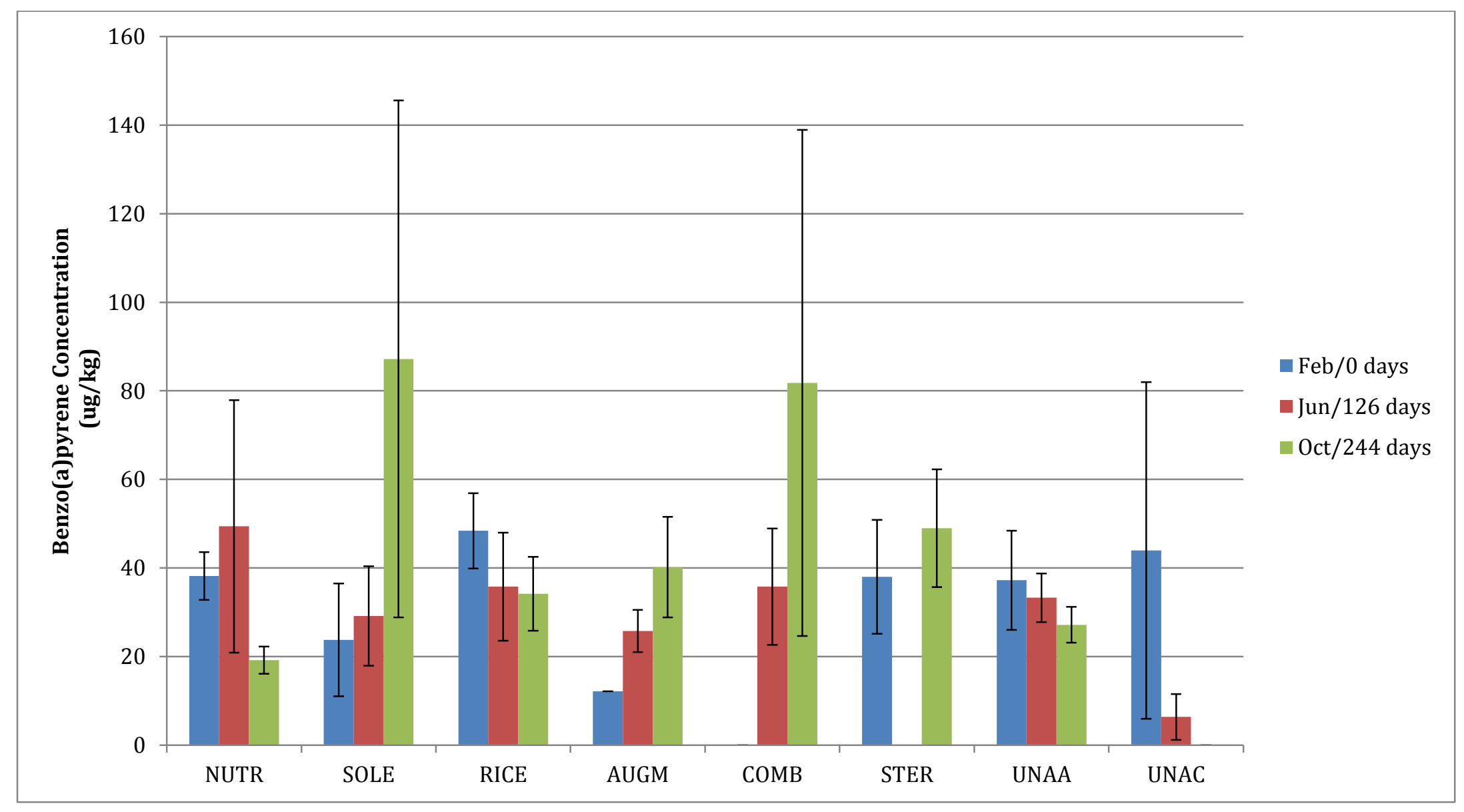

Figure 41: Benzo(a)pyrene concentrations during microcosm incubation (A and C) 


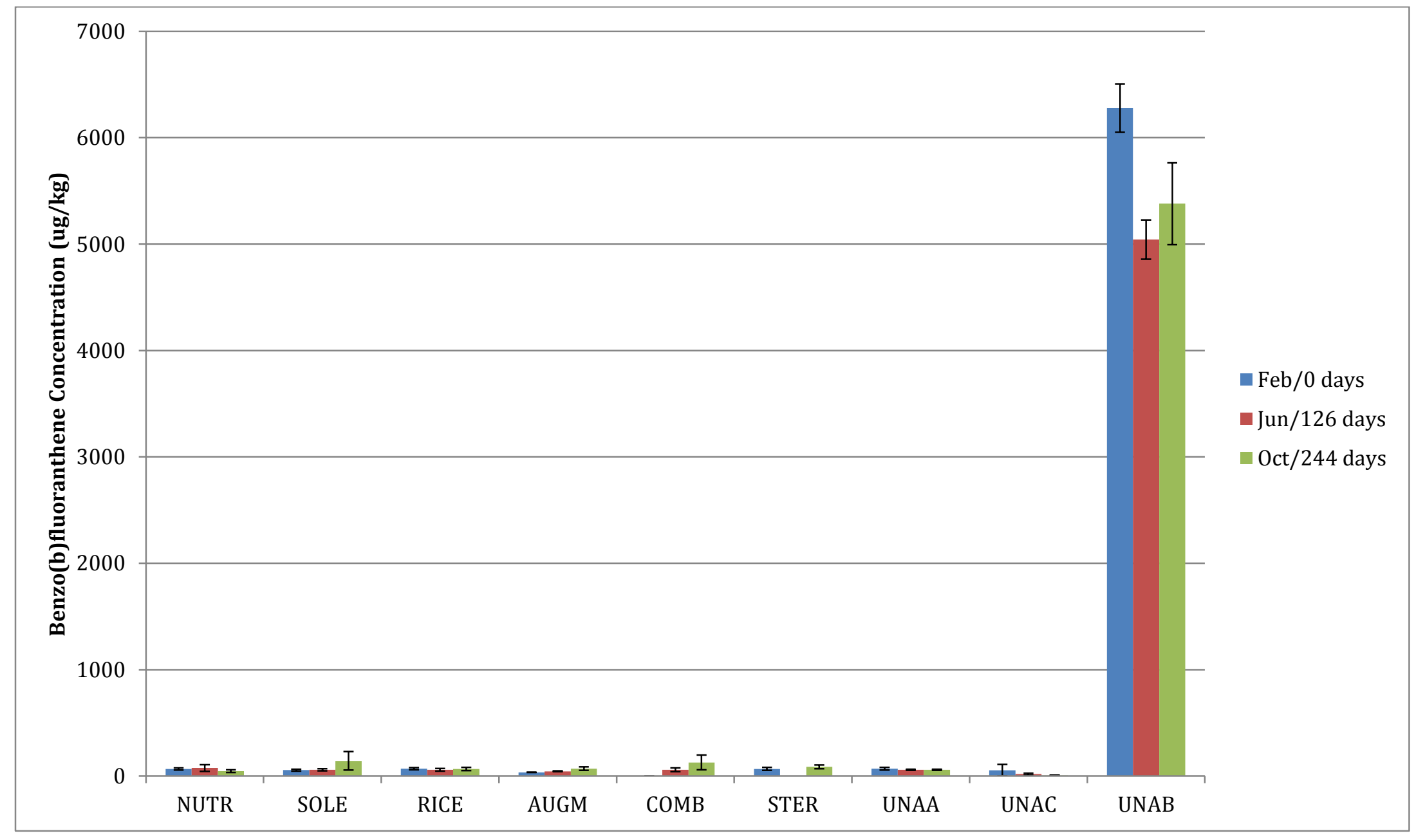

Figure 42: Benzo(b)fluoranthene concentrations during microcosm incubation (all soils) 


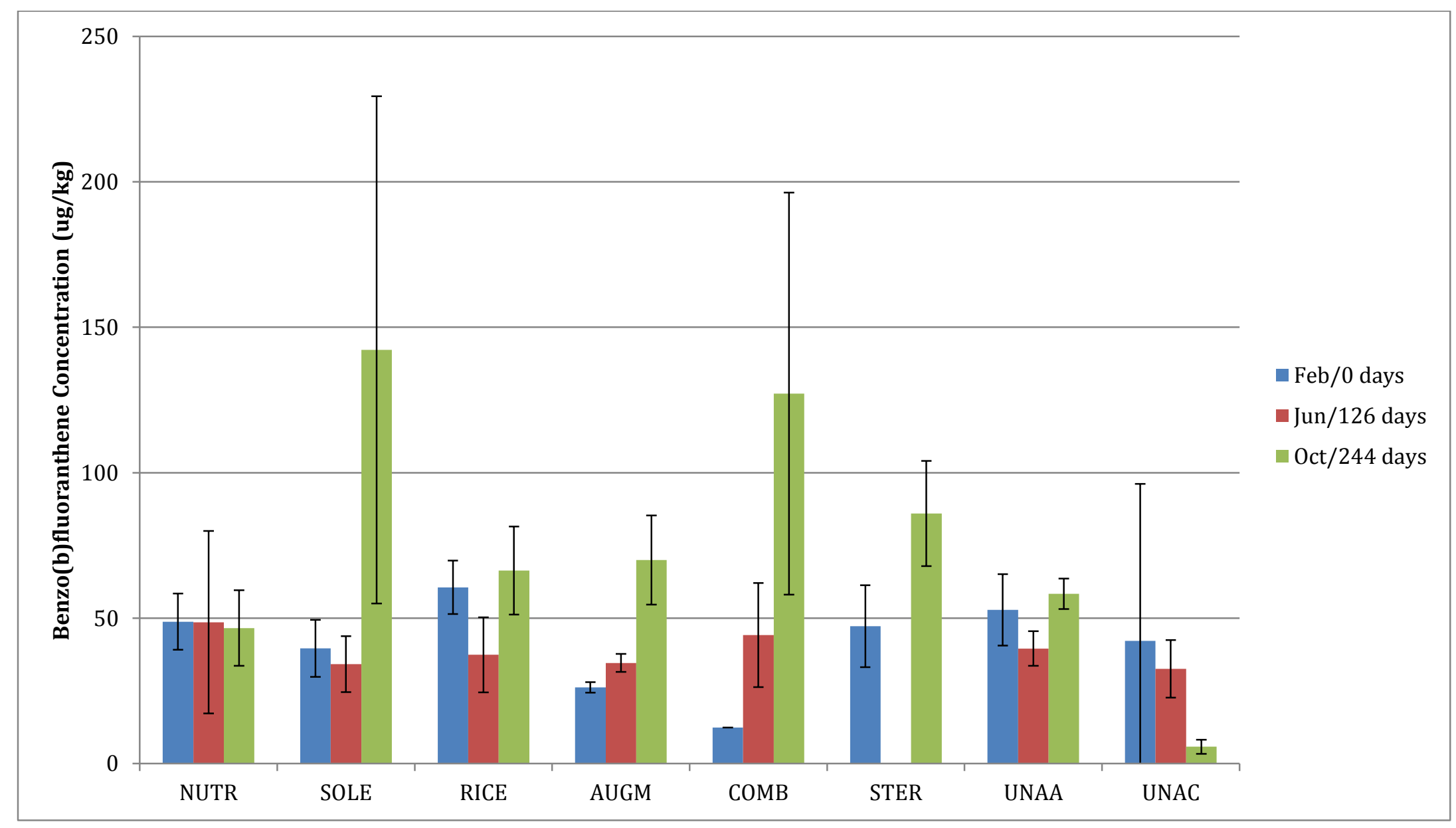

Figure 43: Benzo(b)fluoranthene concentrations during microcosm incubation (A and C) 


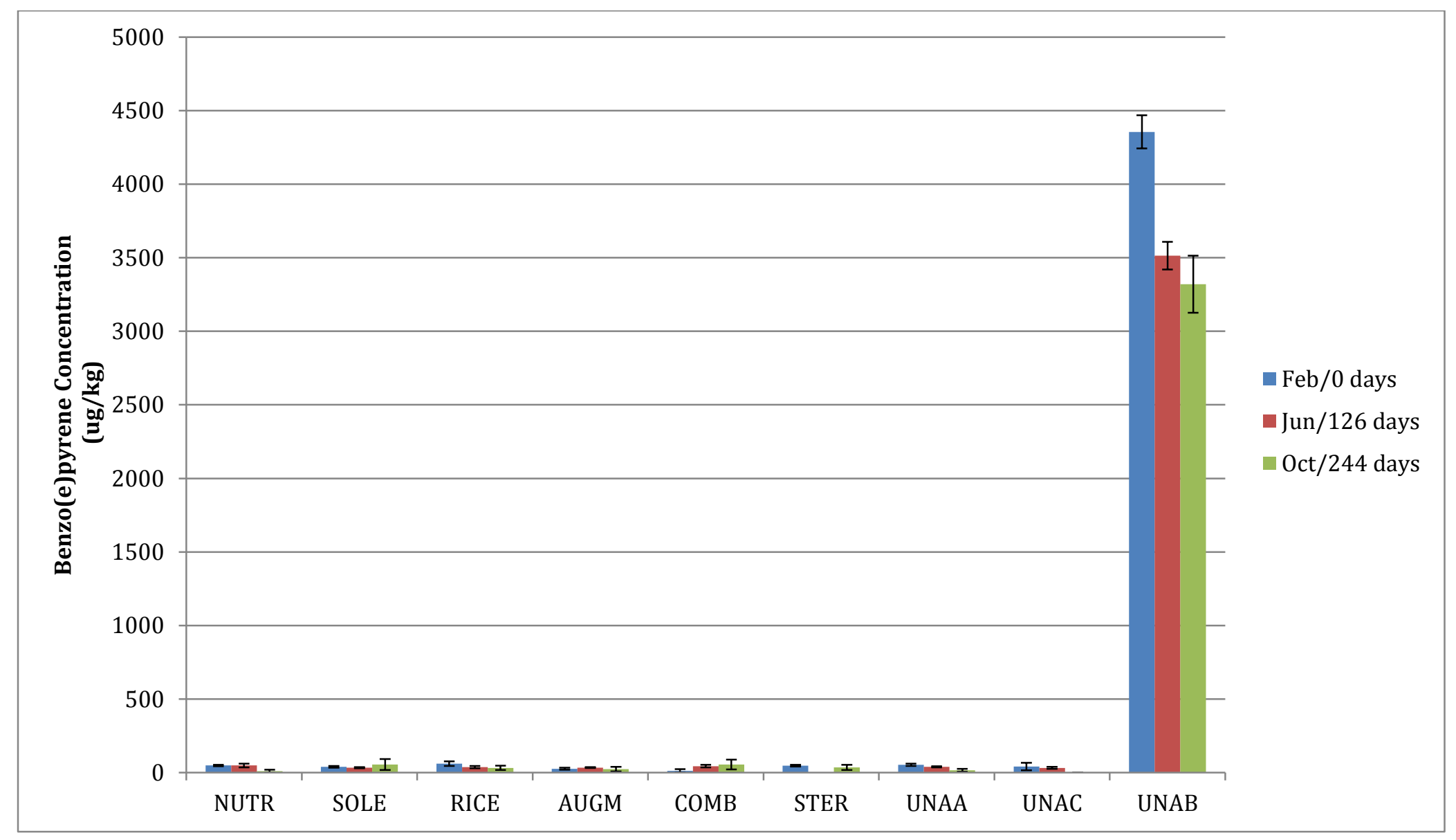

Figure 44: Benzo(e)pyrene concentrations during microcosm incubation (all soils) 


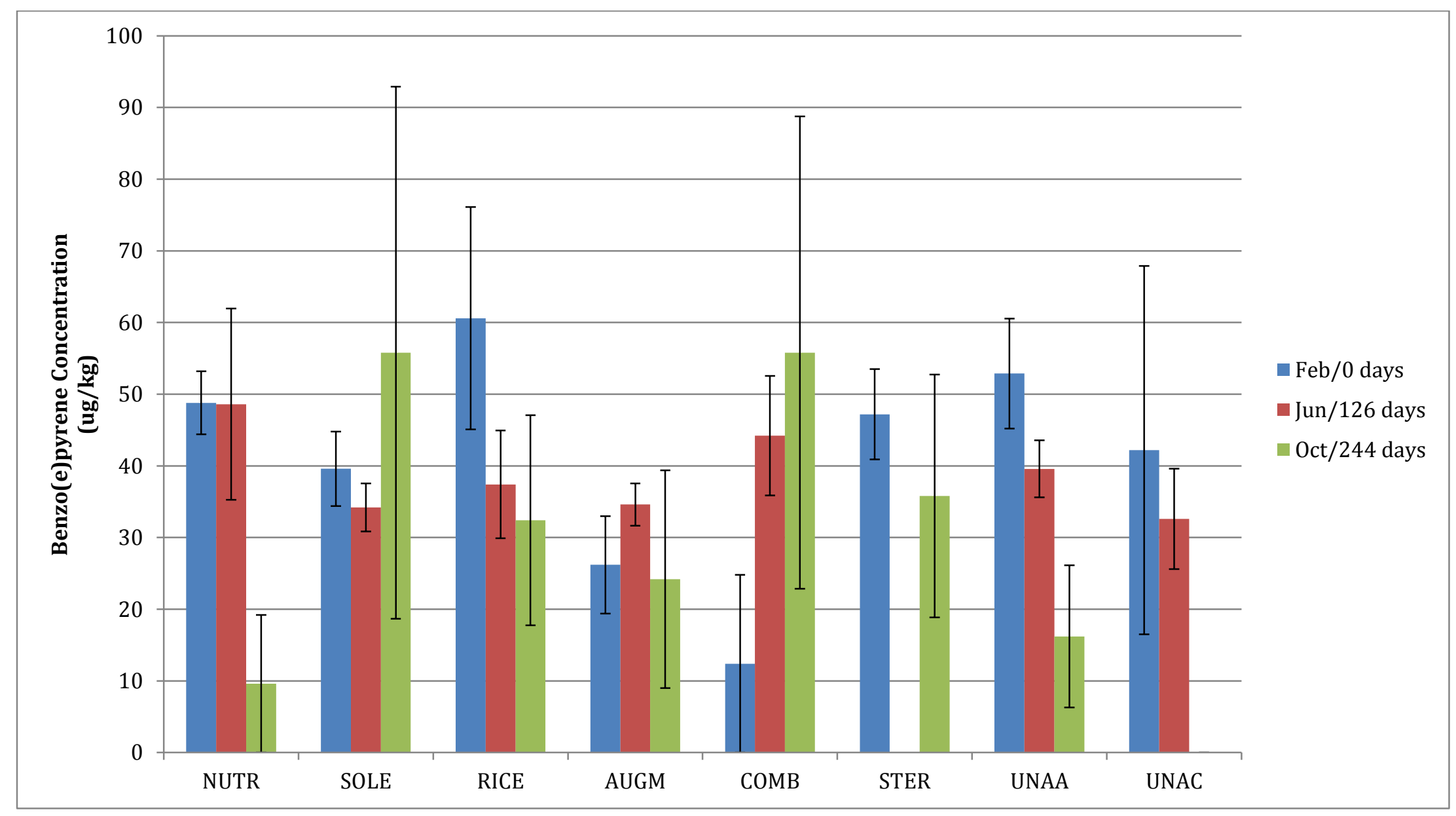

Figure 45: Benzo(e)pyrene concentrations during microcosm incubation (Soils A and C) 


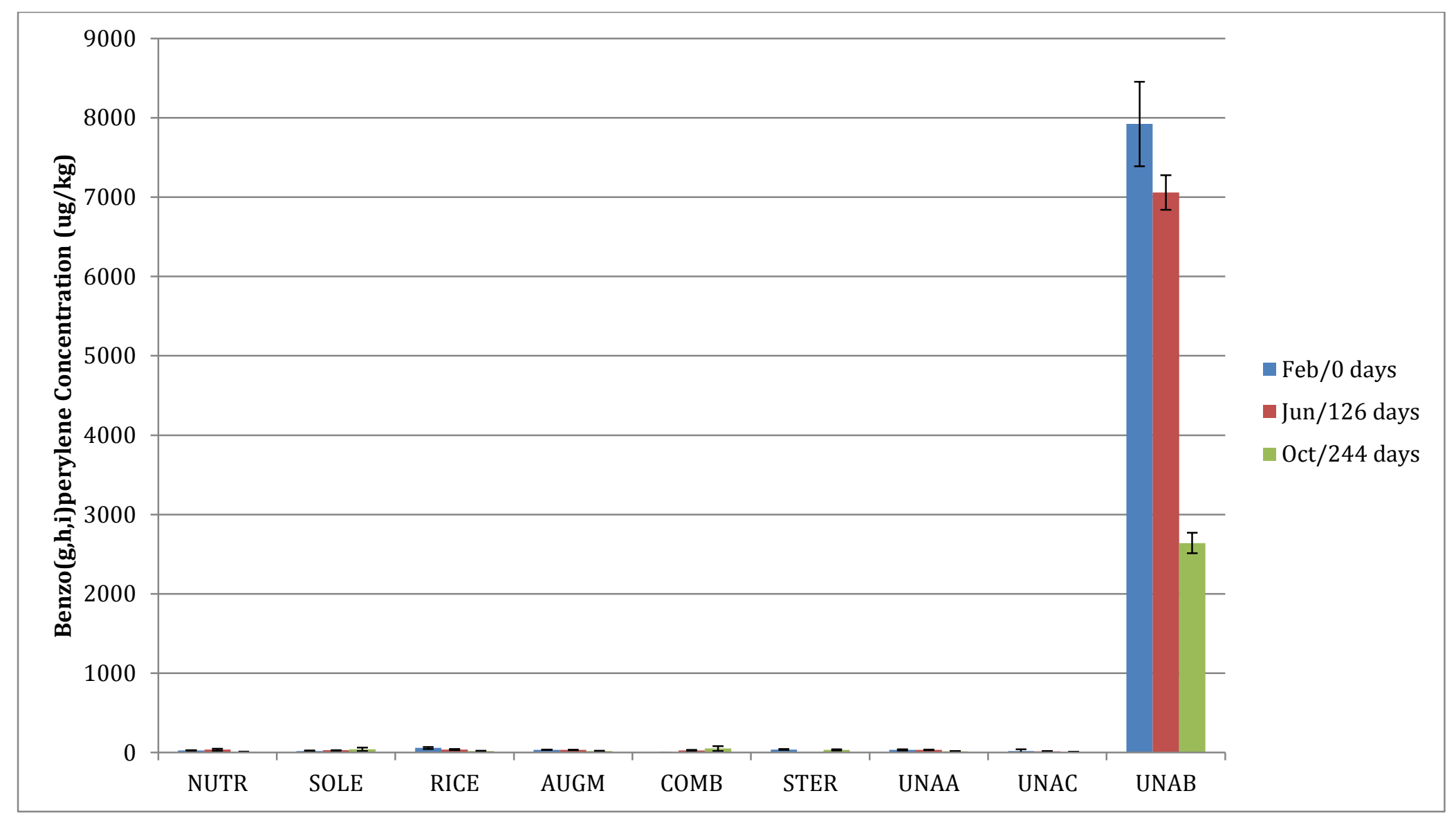

Figure 46: Benzo(g,h,i)perylene concentrations during microcosm incubation (all soils) 


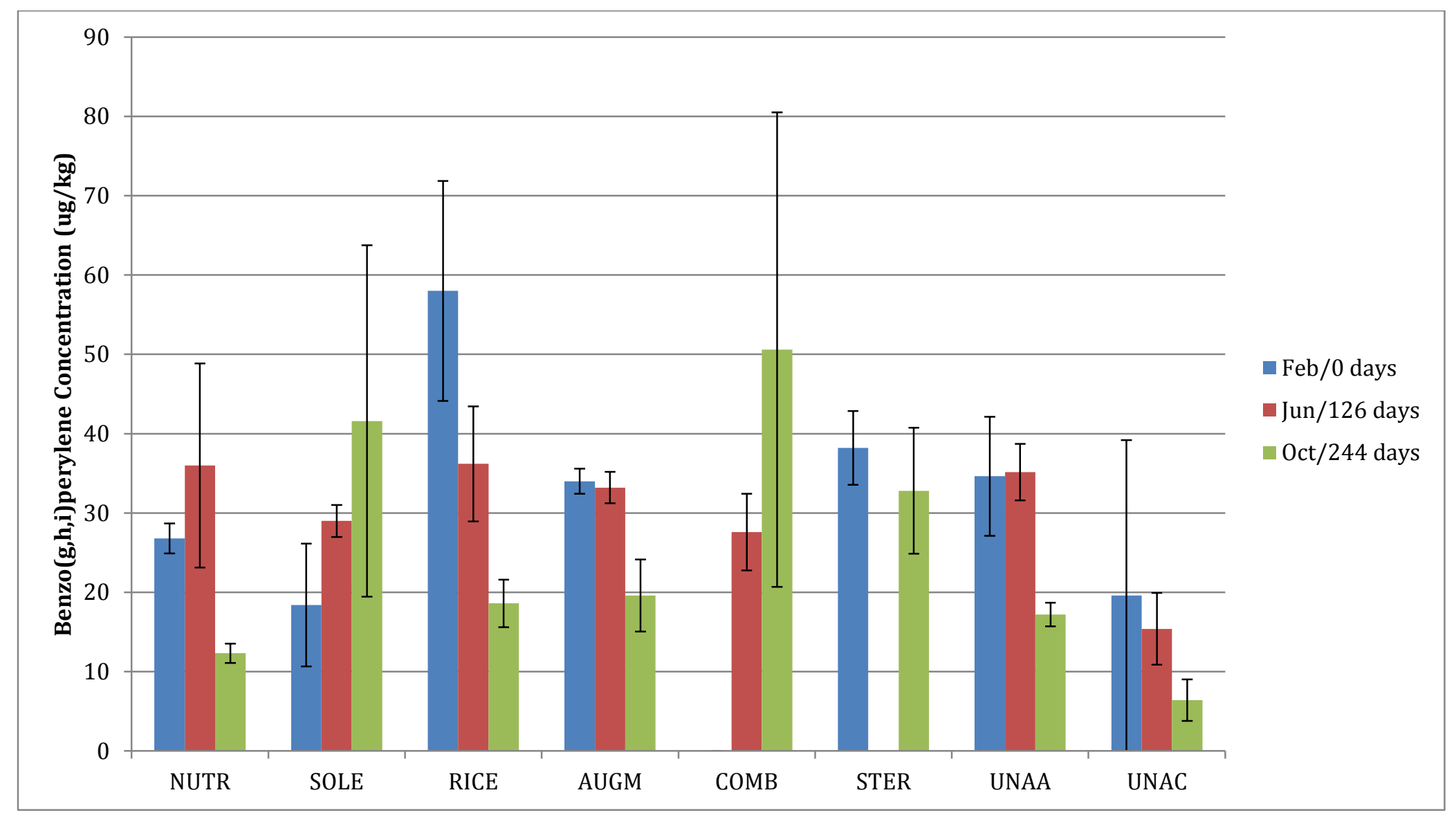

Figure 47: Benzo(g,h,i)perylene concentrations during microcosm incubation (A and C) 


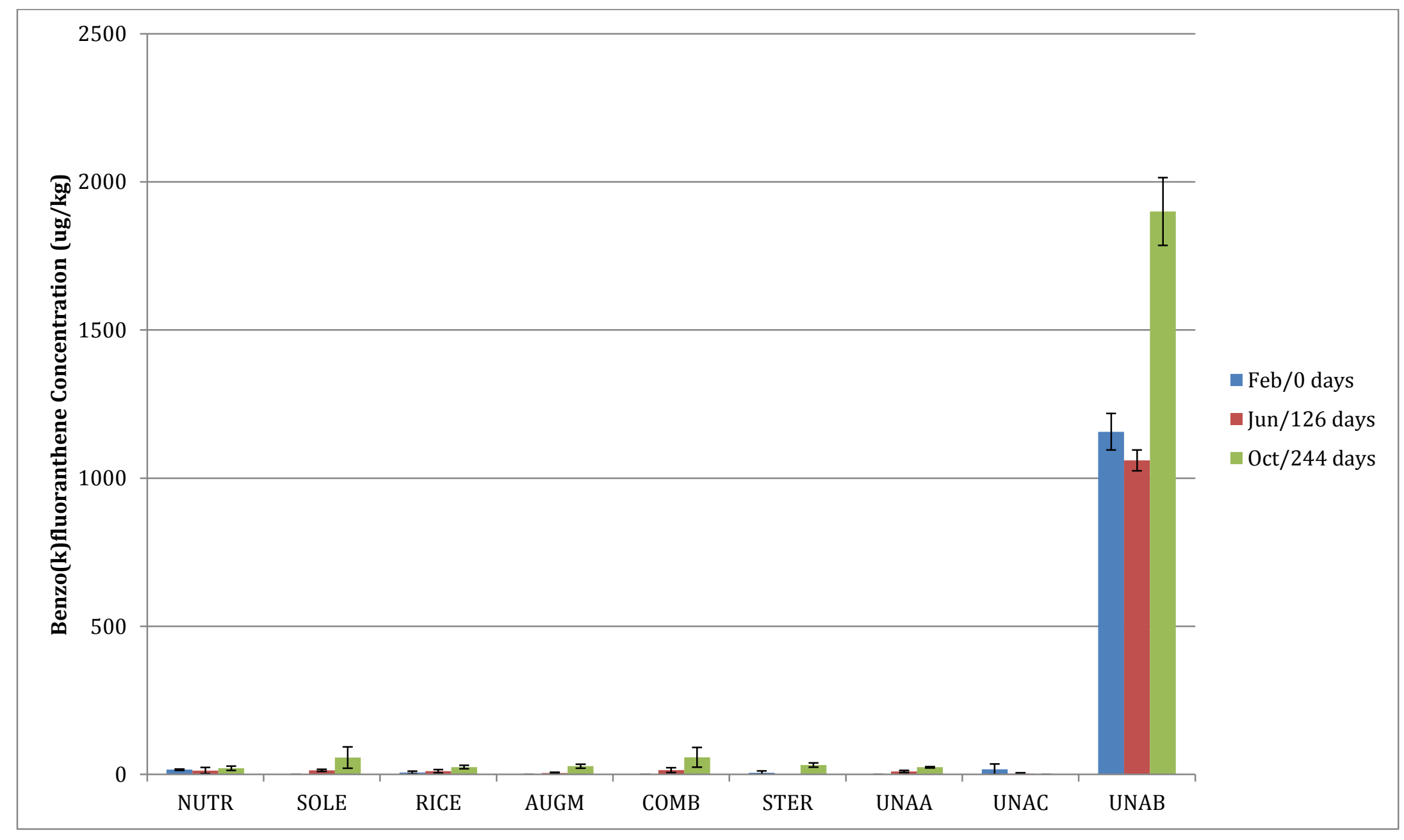

Figure 48: Benzo(k)fluoranthene concentrations during microcosm incubation (all soils) 


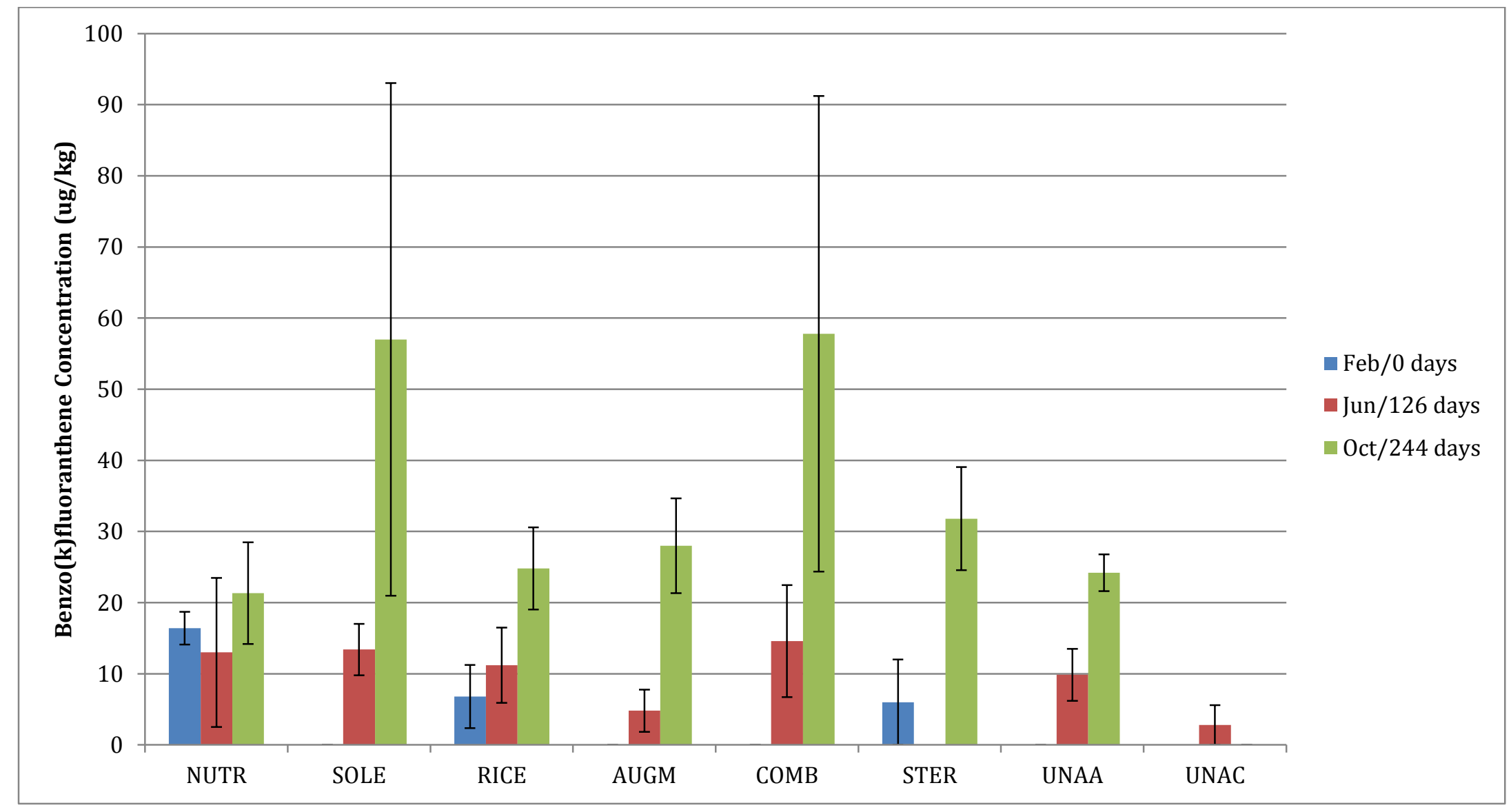

Figure 49: Benzo(k)fluoranthene concentrations during microcosm incubation (A and C) 


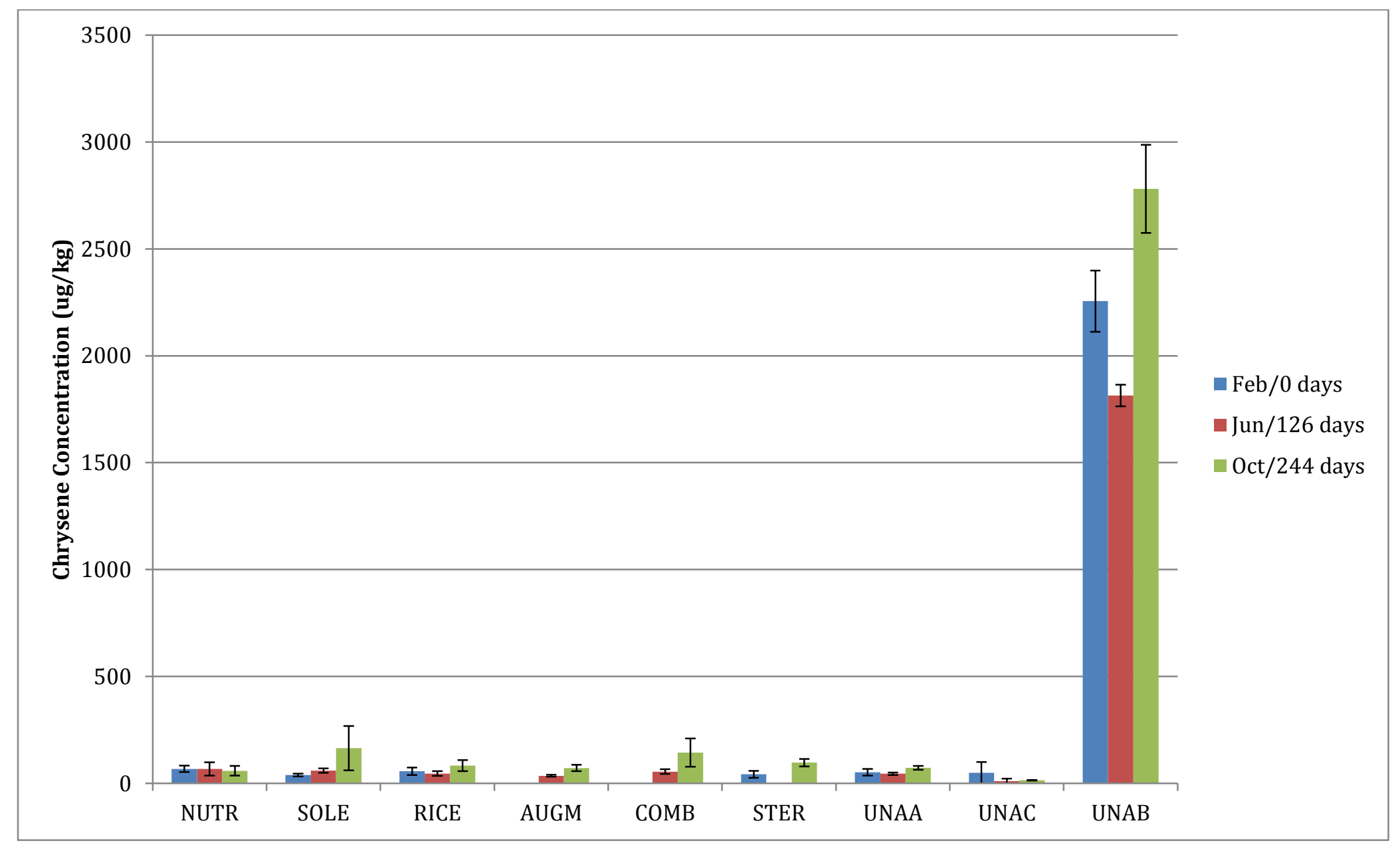

Figure 50: Chrysene concentrations during microcosm incubation (all soils) 


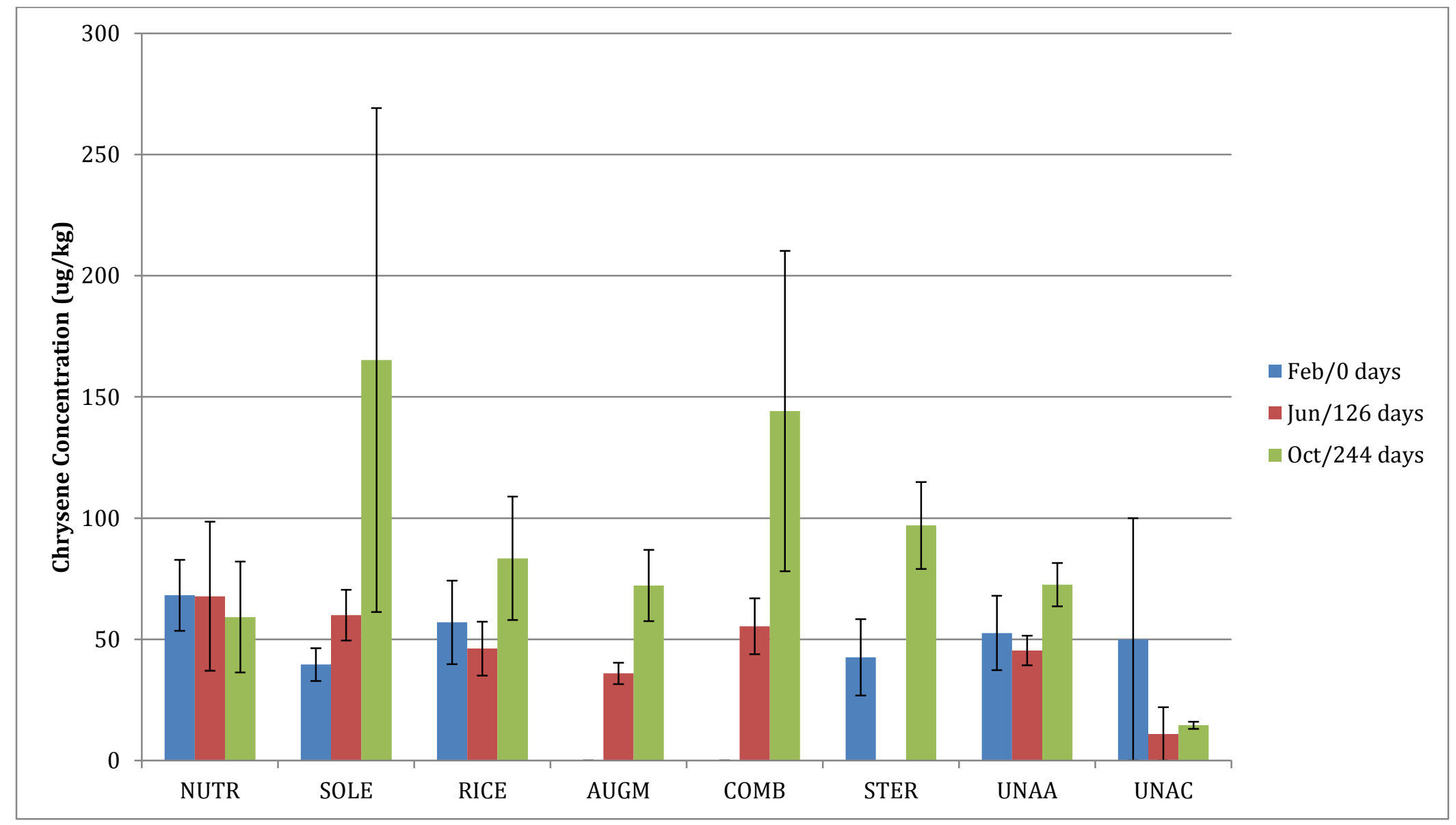

Figure 51: Chrysene concentrations during microcosm incubation (A and C) 


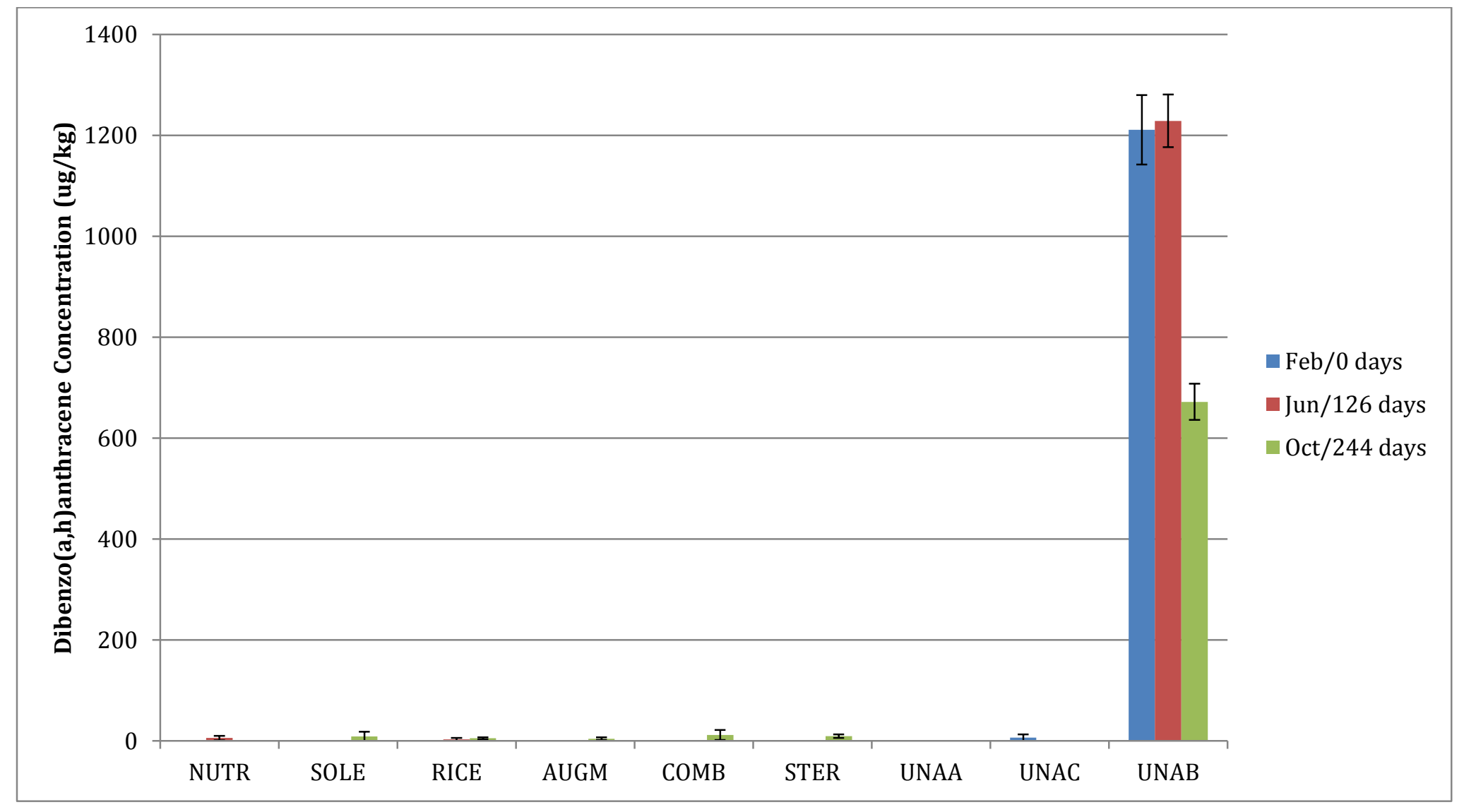

Figure 52: Dibenzo(a,h)anthracene concentrations during microcosm incubation (all soils) 


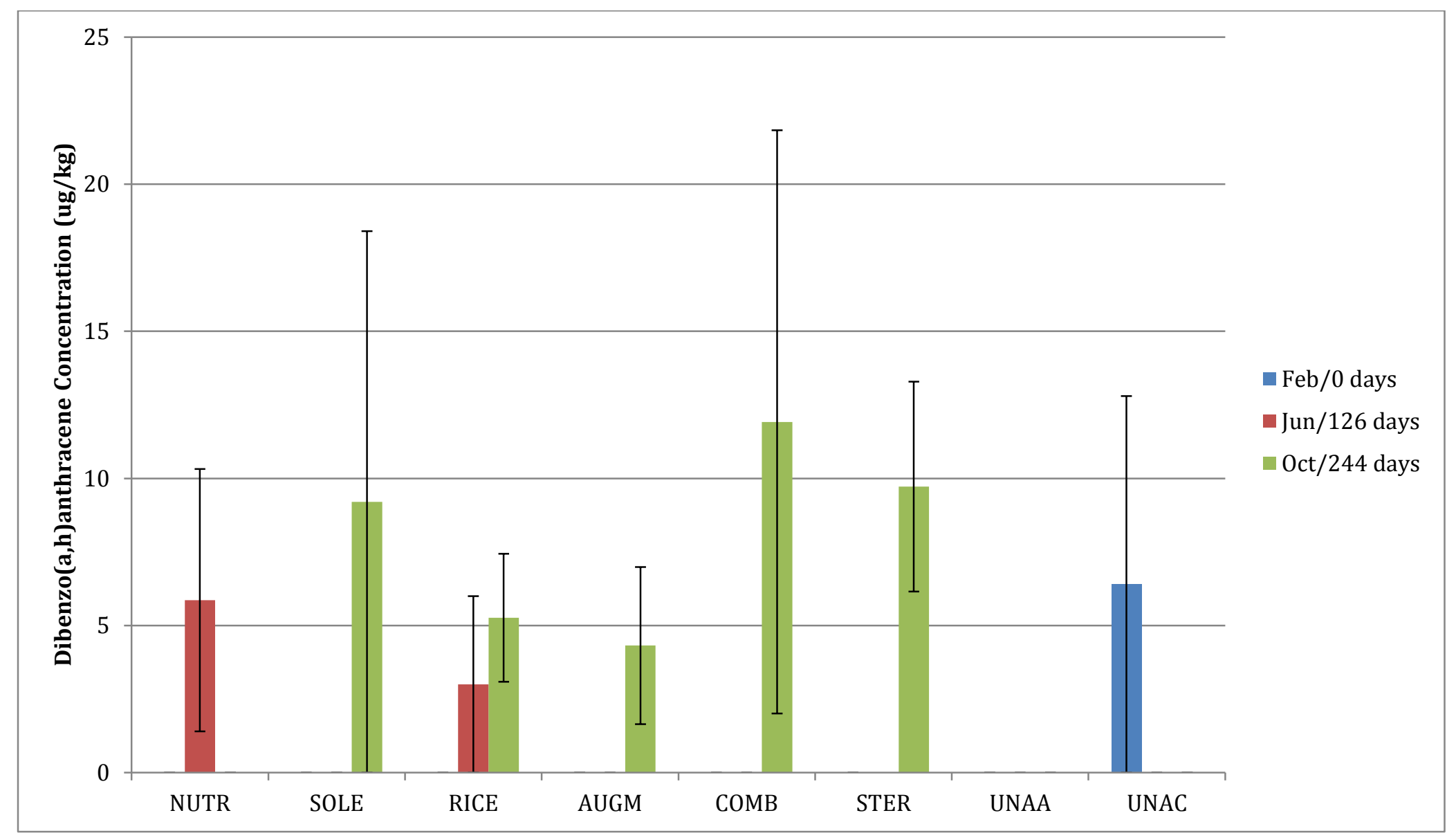

Figure 53: Dibenzo(a,h)anthracene concentrations during microcosm incubation (A and C) 


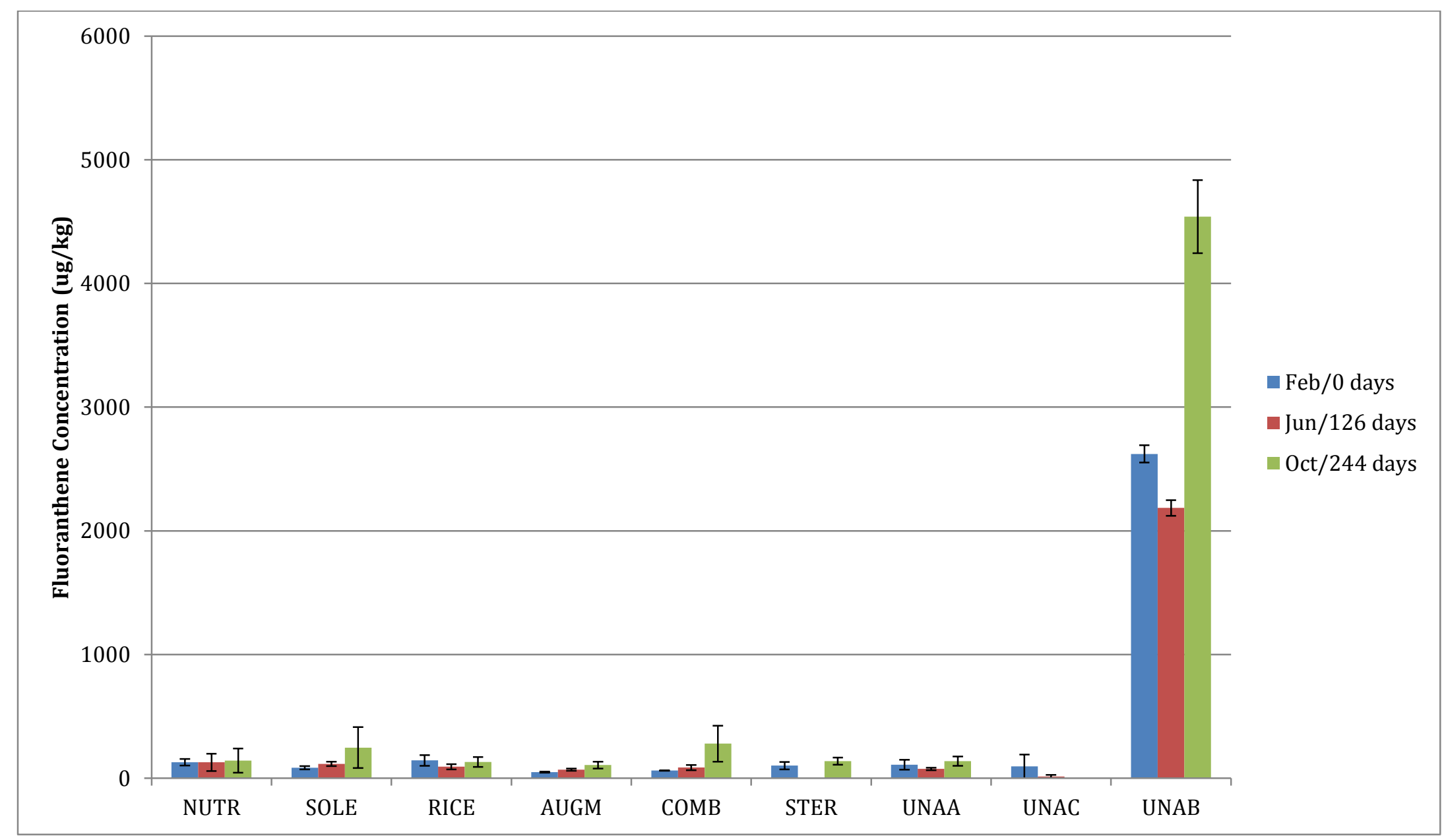

Figure 54: Fluoranthene concentrations during microcosm incubation (all soils) 


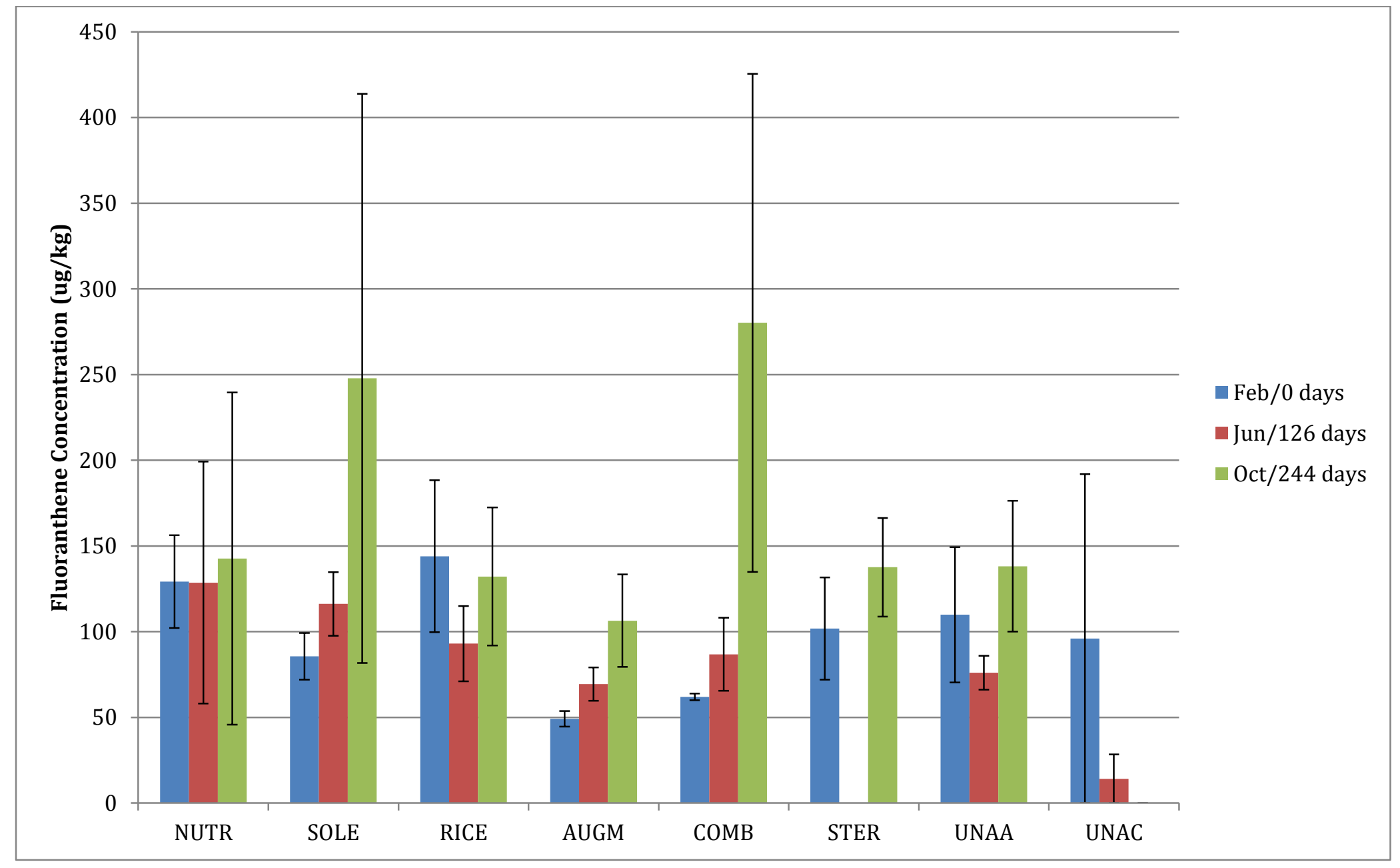

Figure 55: Flouranthene concentrations during microcosm incubation (A and C) 


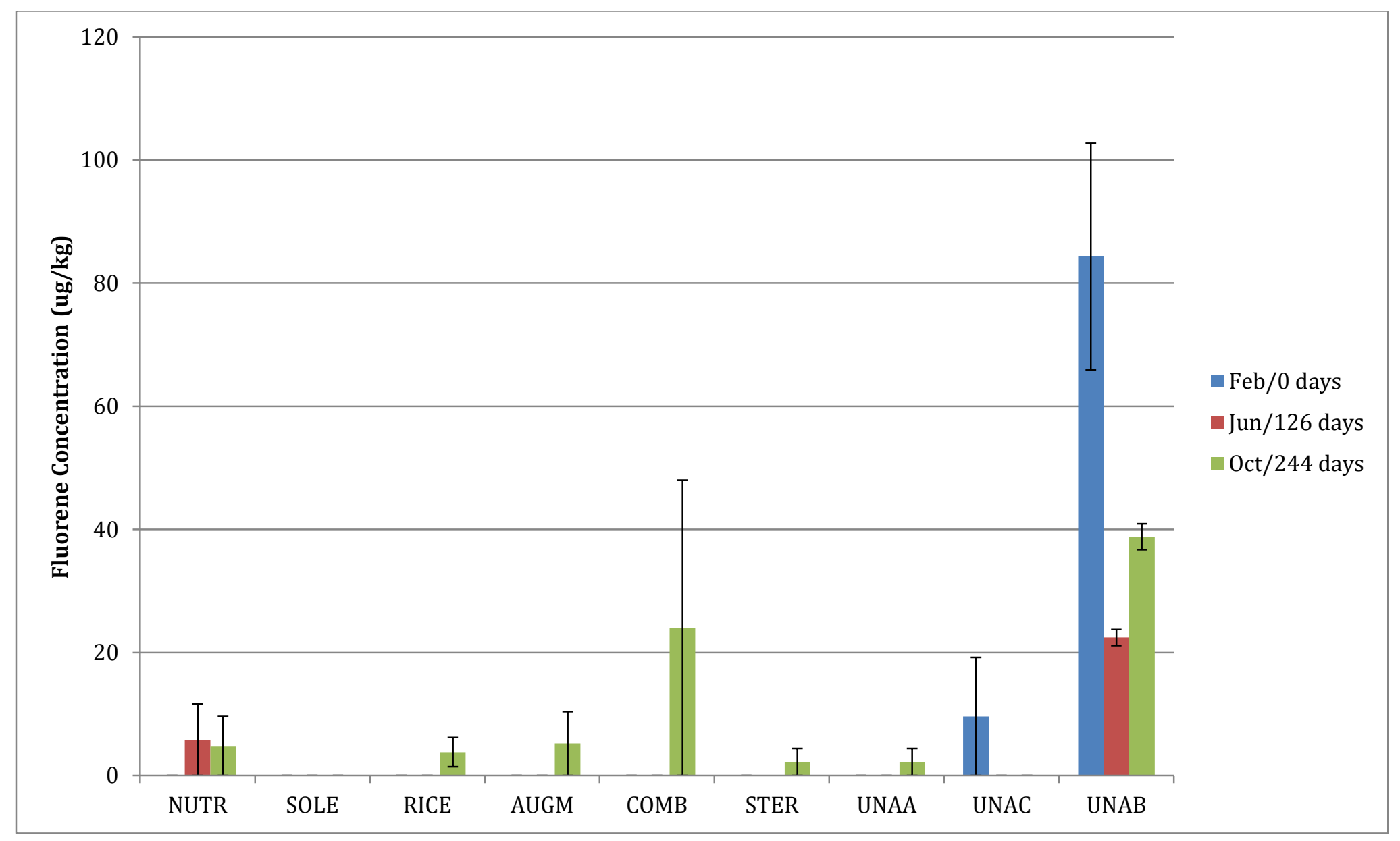

Figure 56: Fluorene concentrations during microcosm incubation (all soils) 


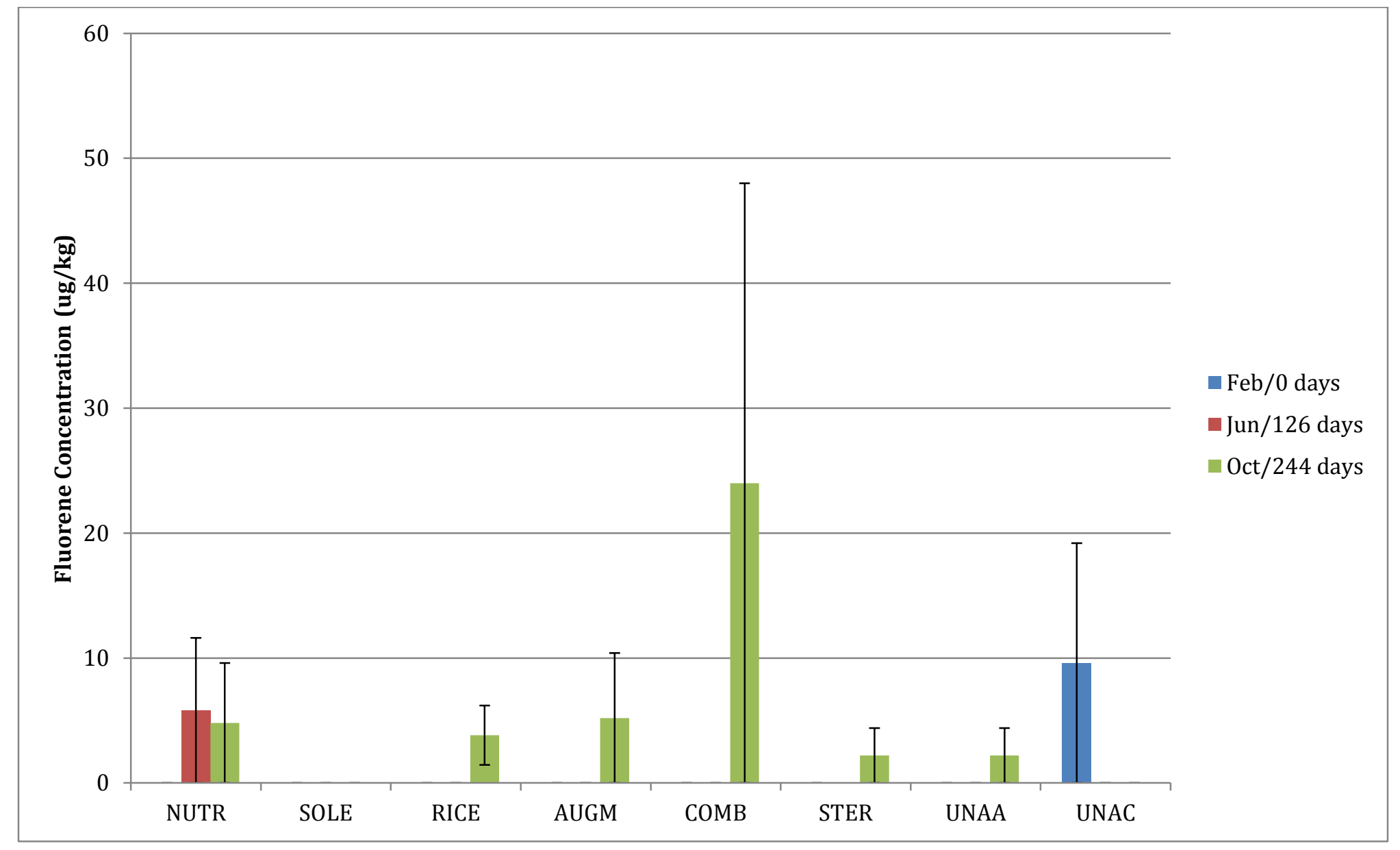

Figure 57: Fluorene concentrations during microcosm incubation (A and C) 


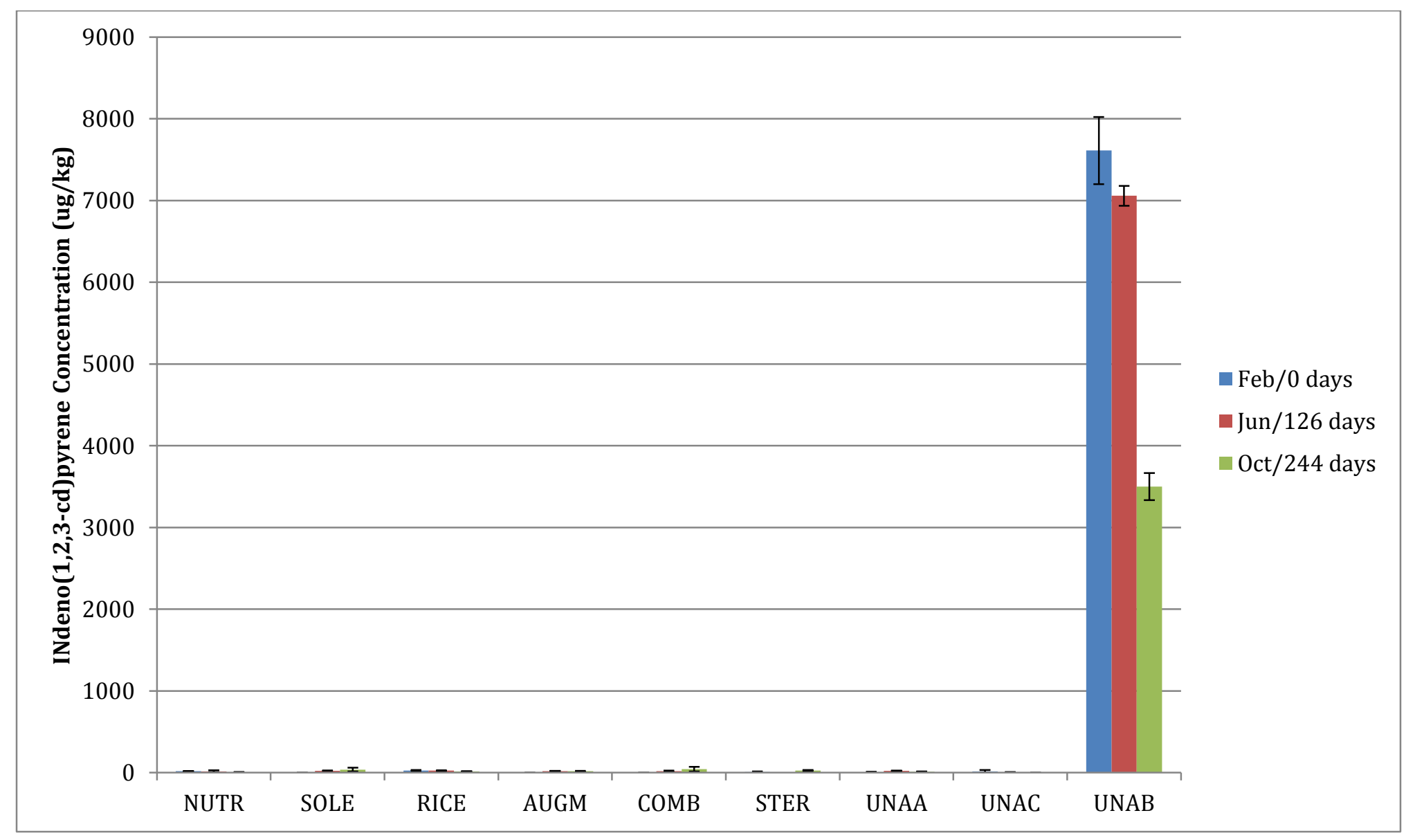

Figure 58: Indeno(1,2,3-cd)pyrene concentrations during microcosm incubation (all soils) 


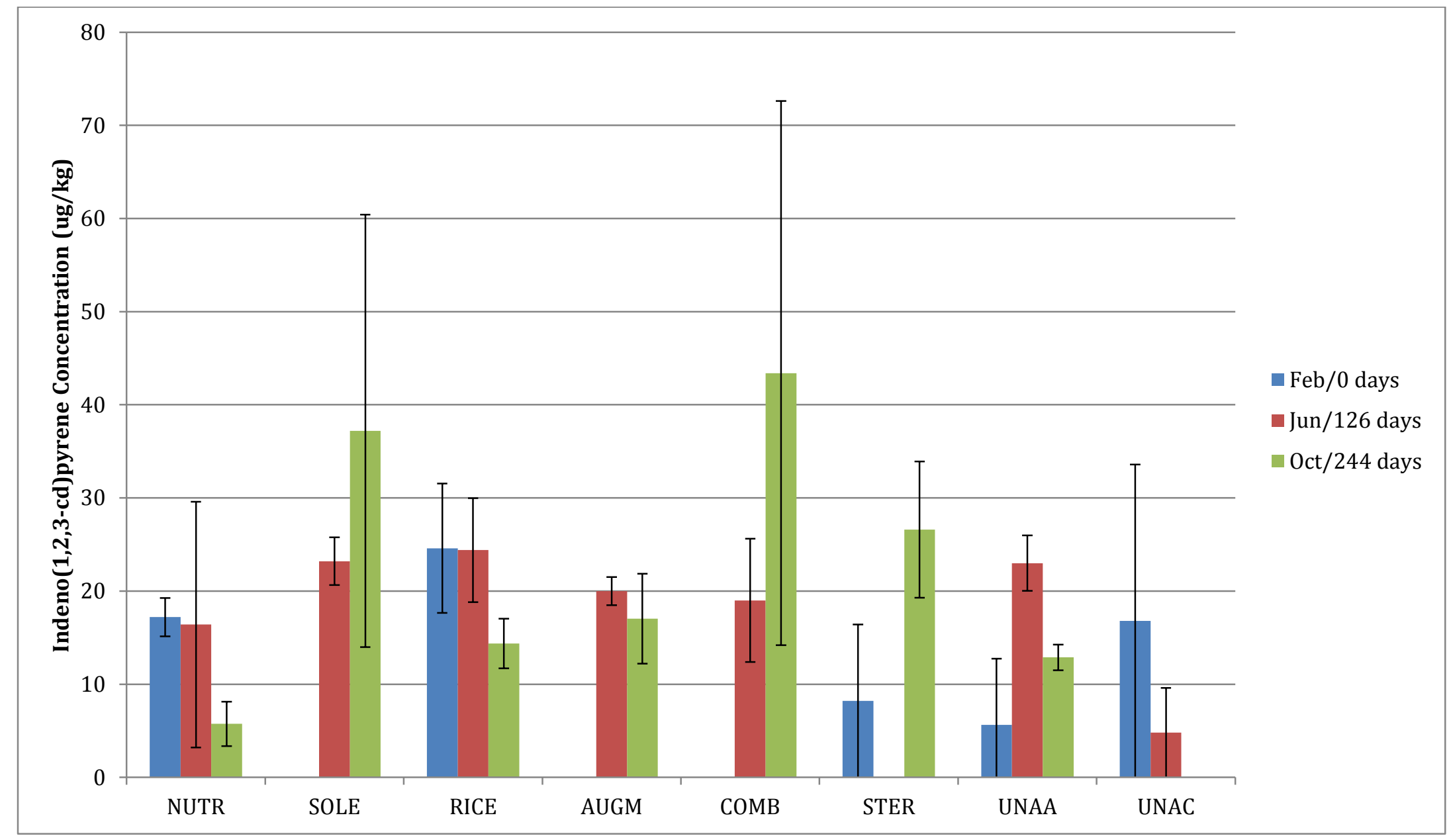

Figure 59: Indeno(1,2,3-cd)pyrene concentrations during microcosm incubation (A and C) 


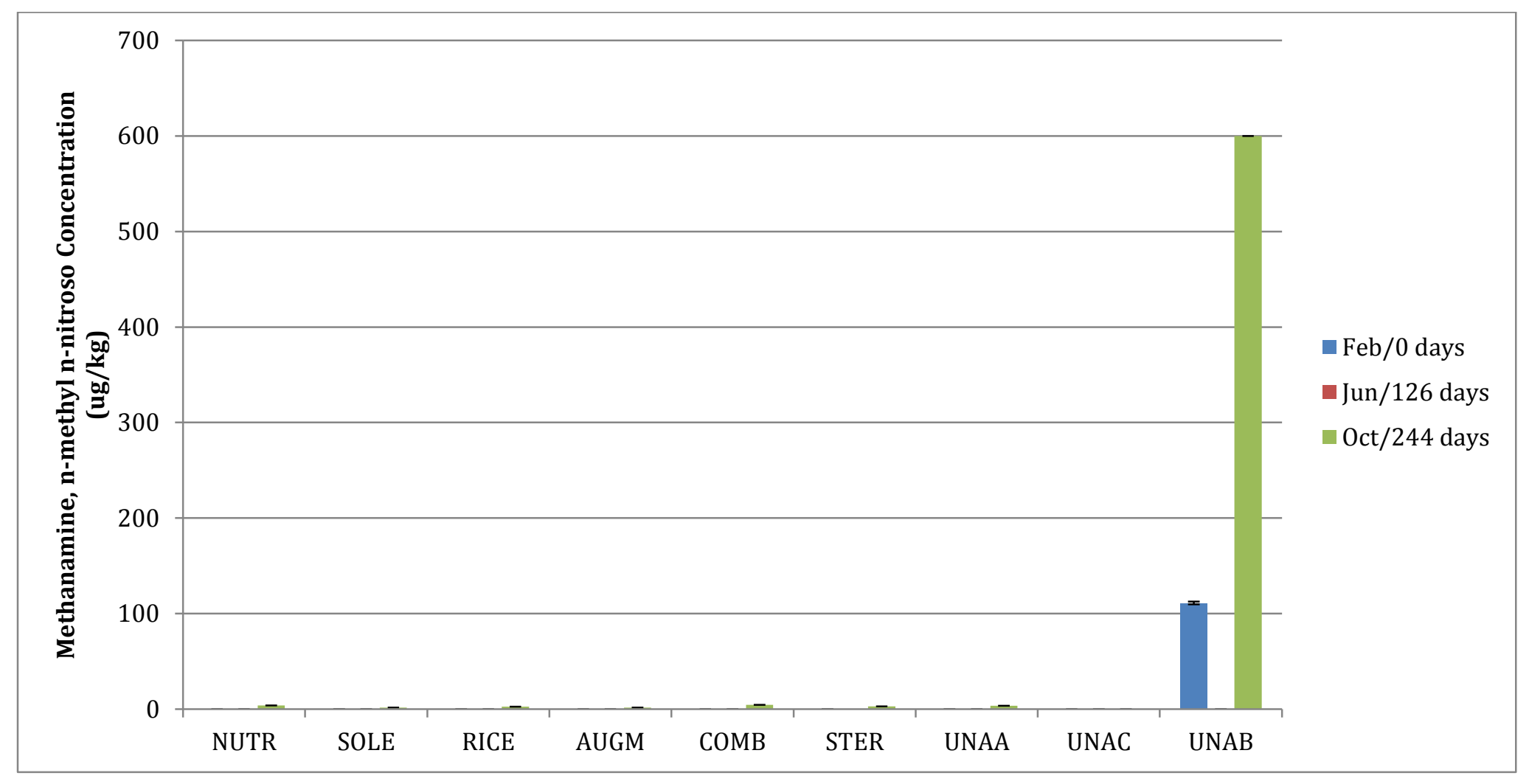

Figure 60: Methanamine, n-methyl n-nitroso concentrations during microcosm incubation 


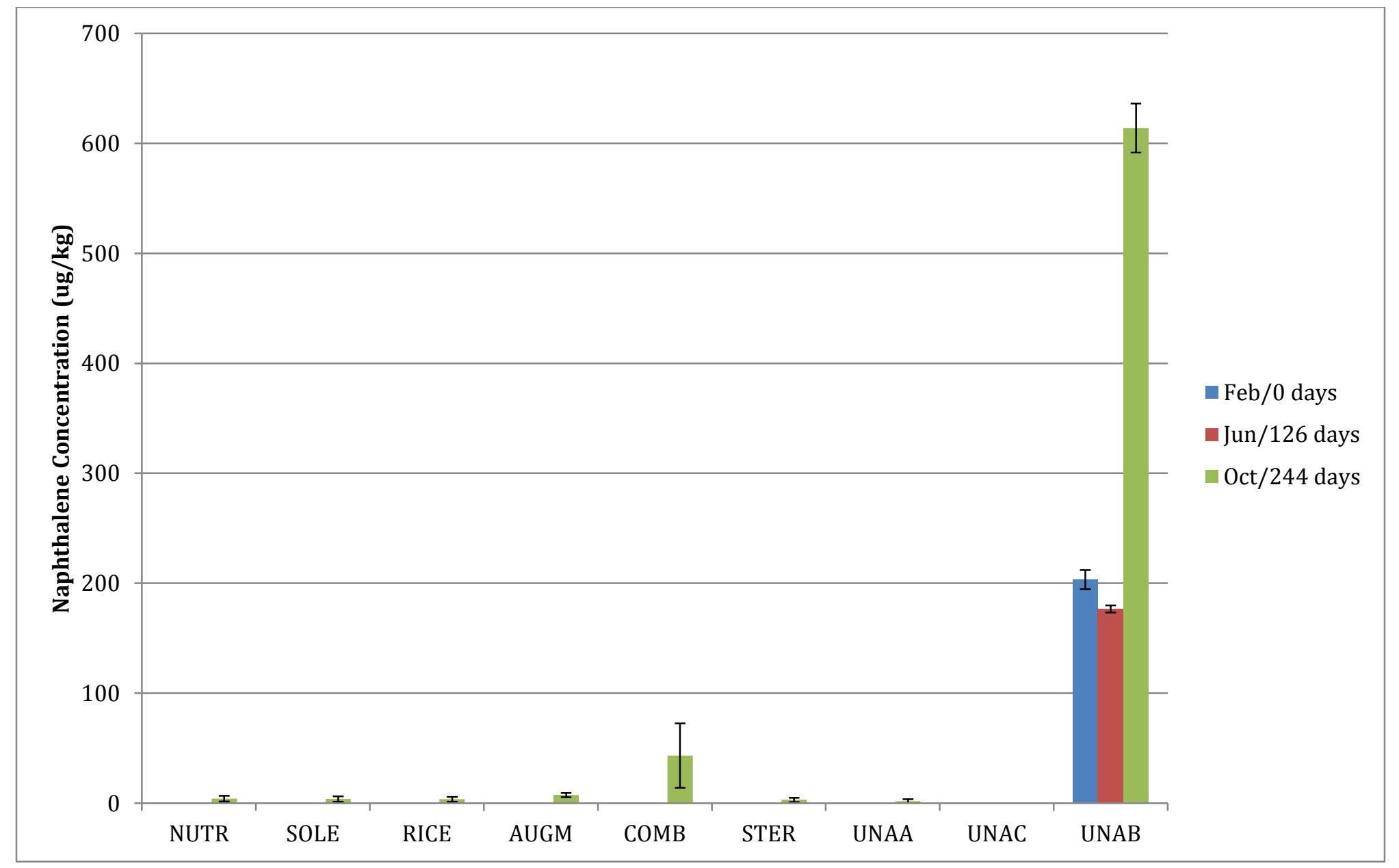

Figure 61: Naphthalene concentrations during microcosm incubation (all soils) 
Appendix D: Bar Graphs of Aroclor Concentrations

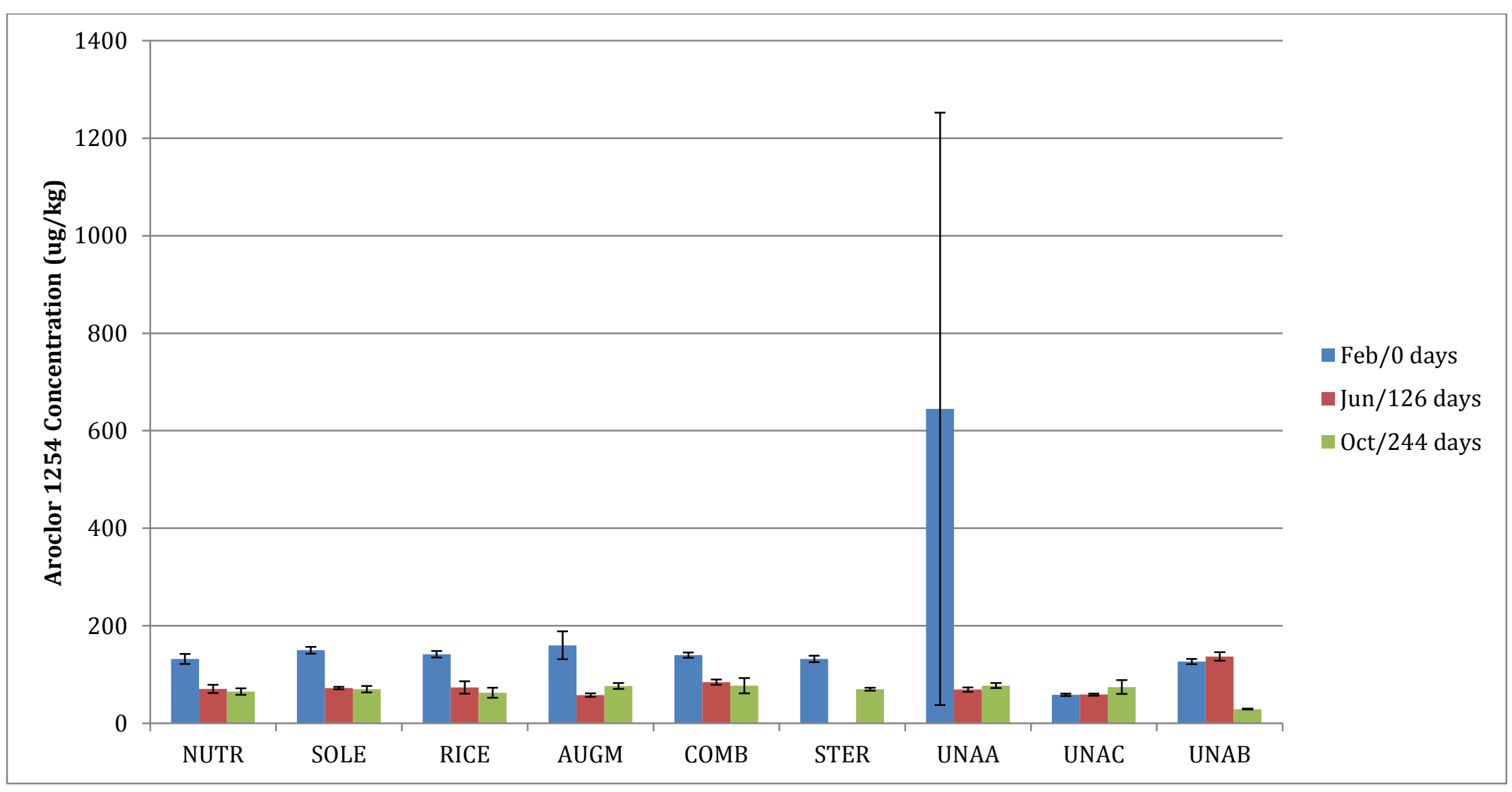

Figure 62: Aroclor 1254 concentration during microcosm incubation 


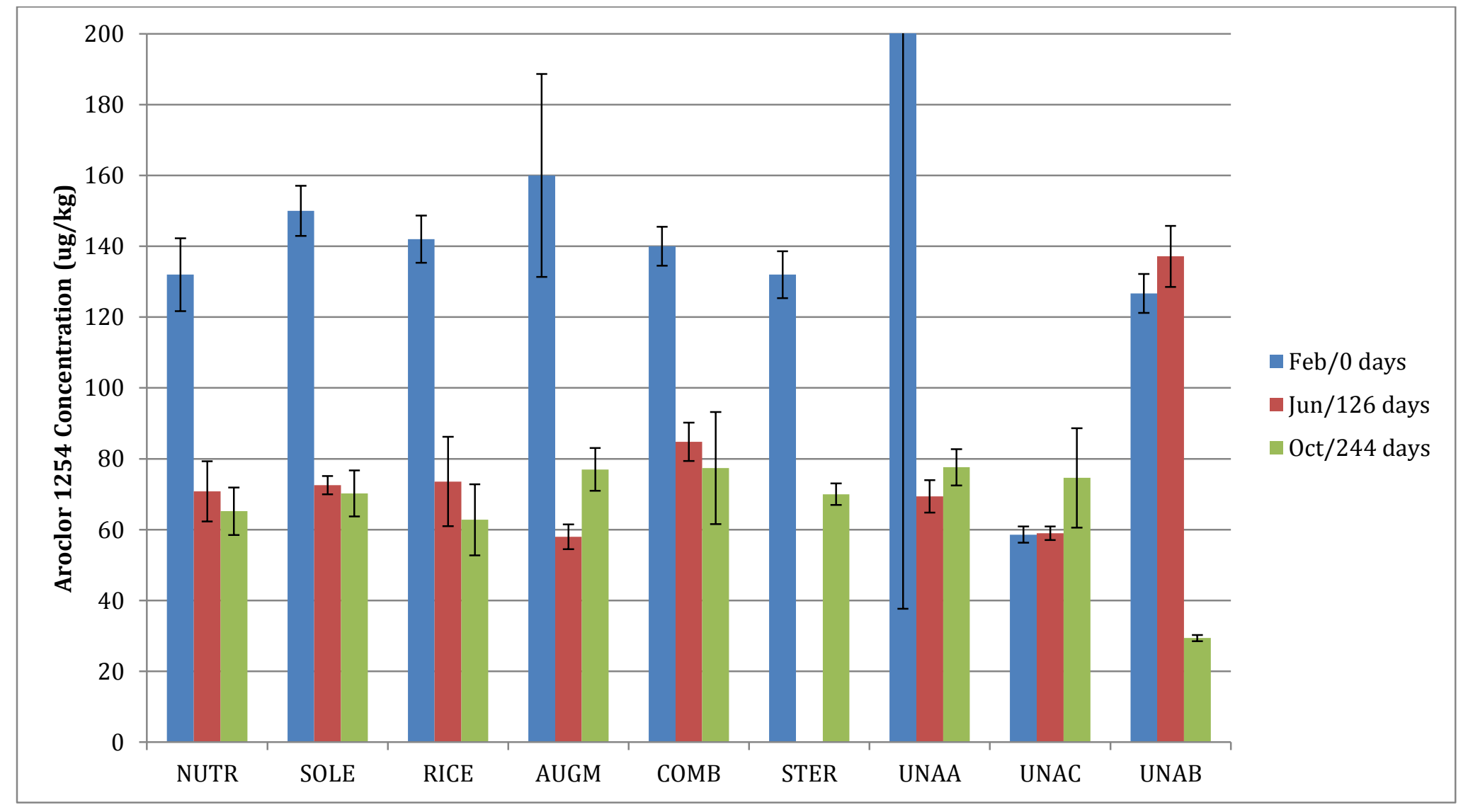

Figure 63: Truncated Aroclor 1254 concentrations during microcosm incubation 


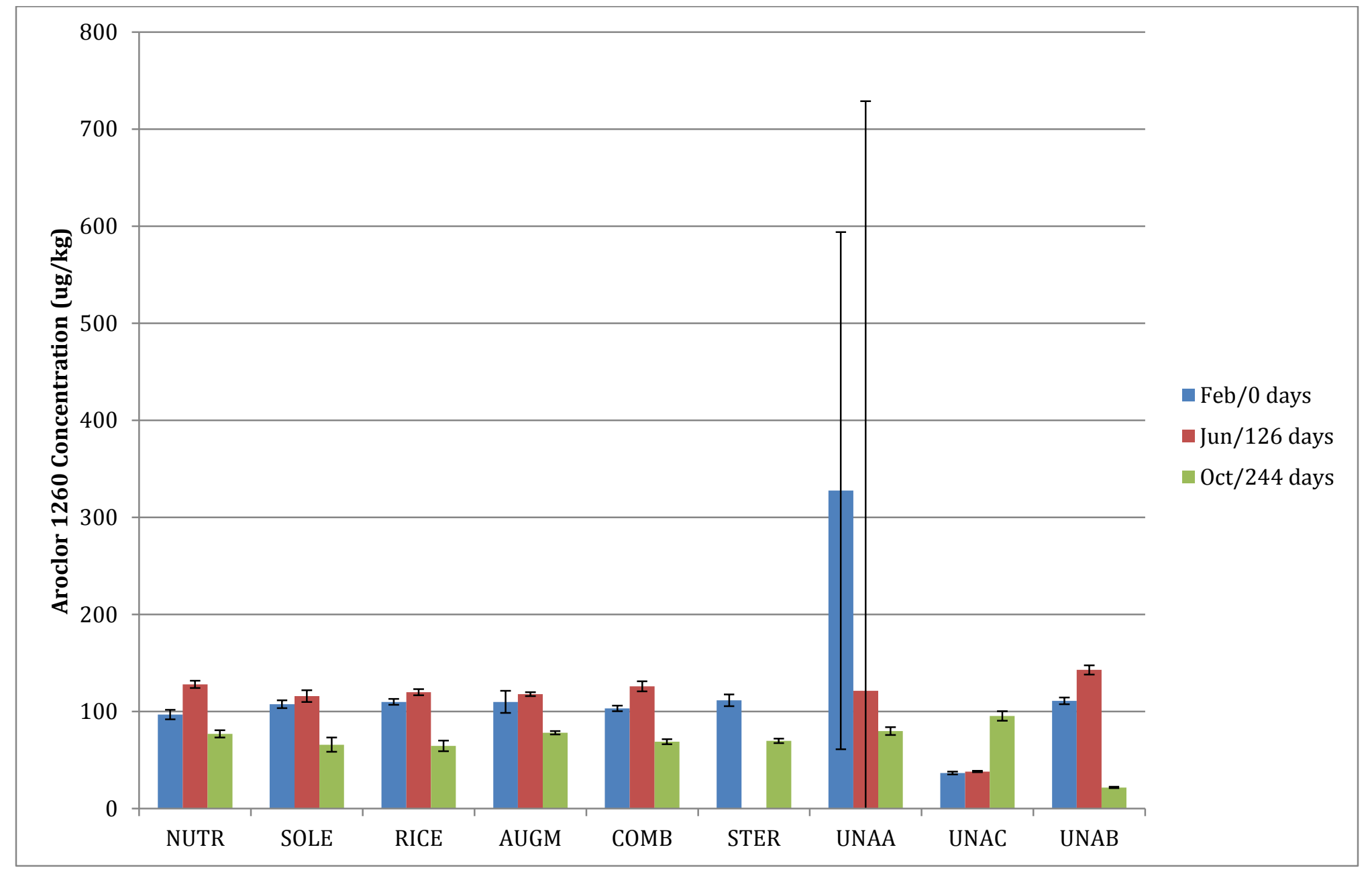

Figure 64: Aroclor 1260 concentrations during microcosm incubation 


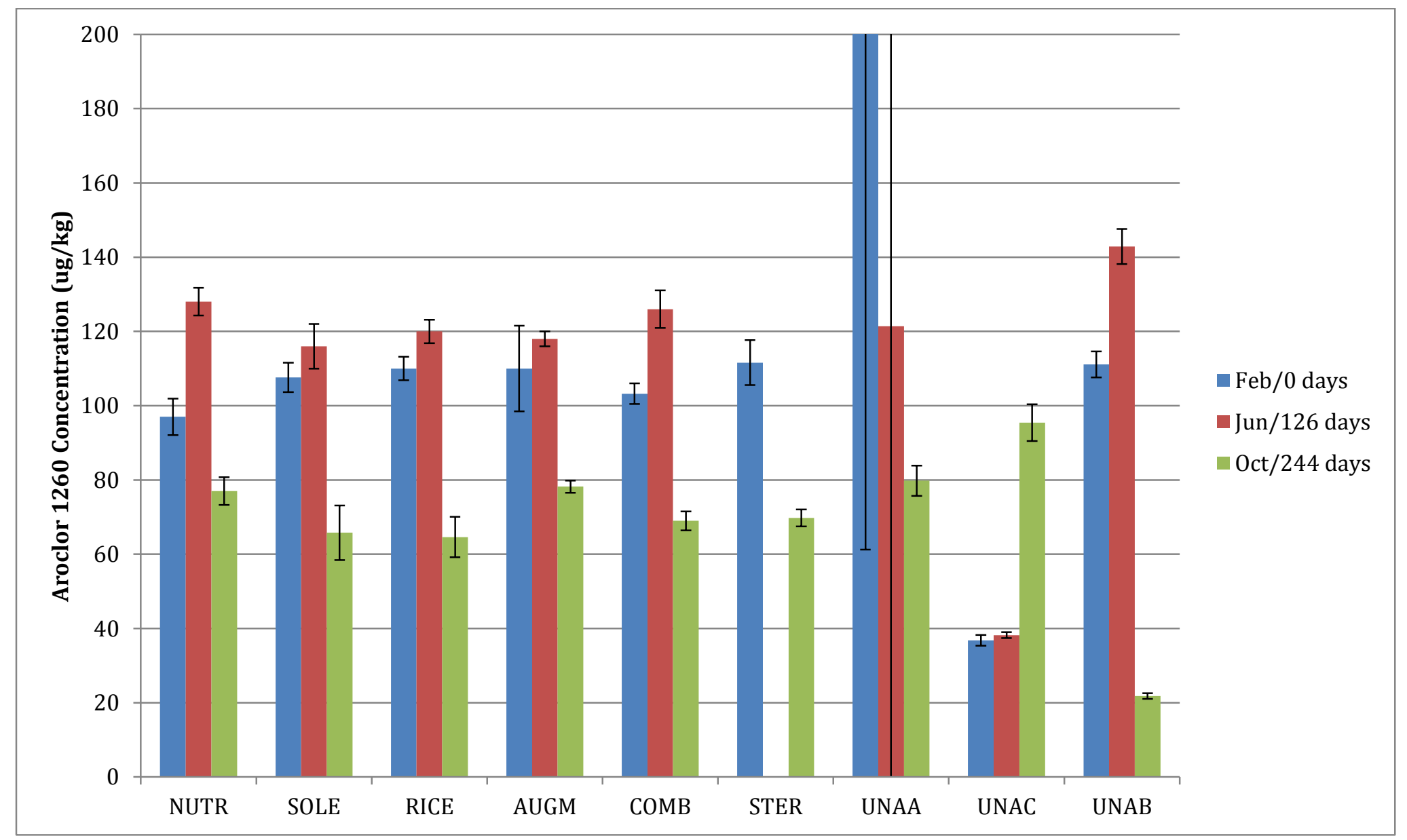

Figure 65: Truncated Aroclor 1260 concentrations during microcosm incubation 


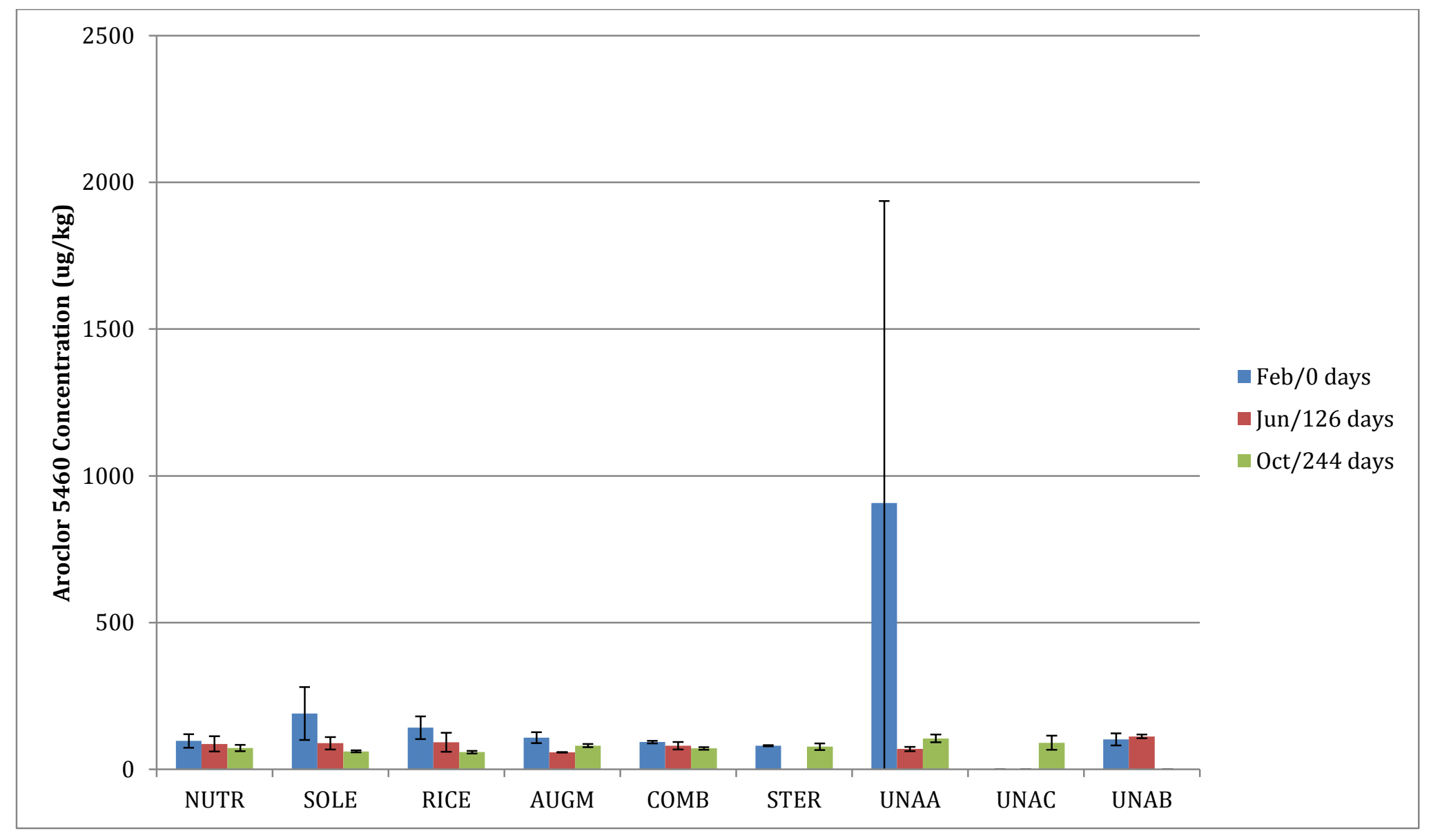

Figure 66: Aroclor 5460 concentrations during microcosm incubation 


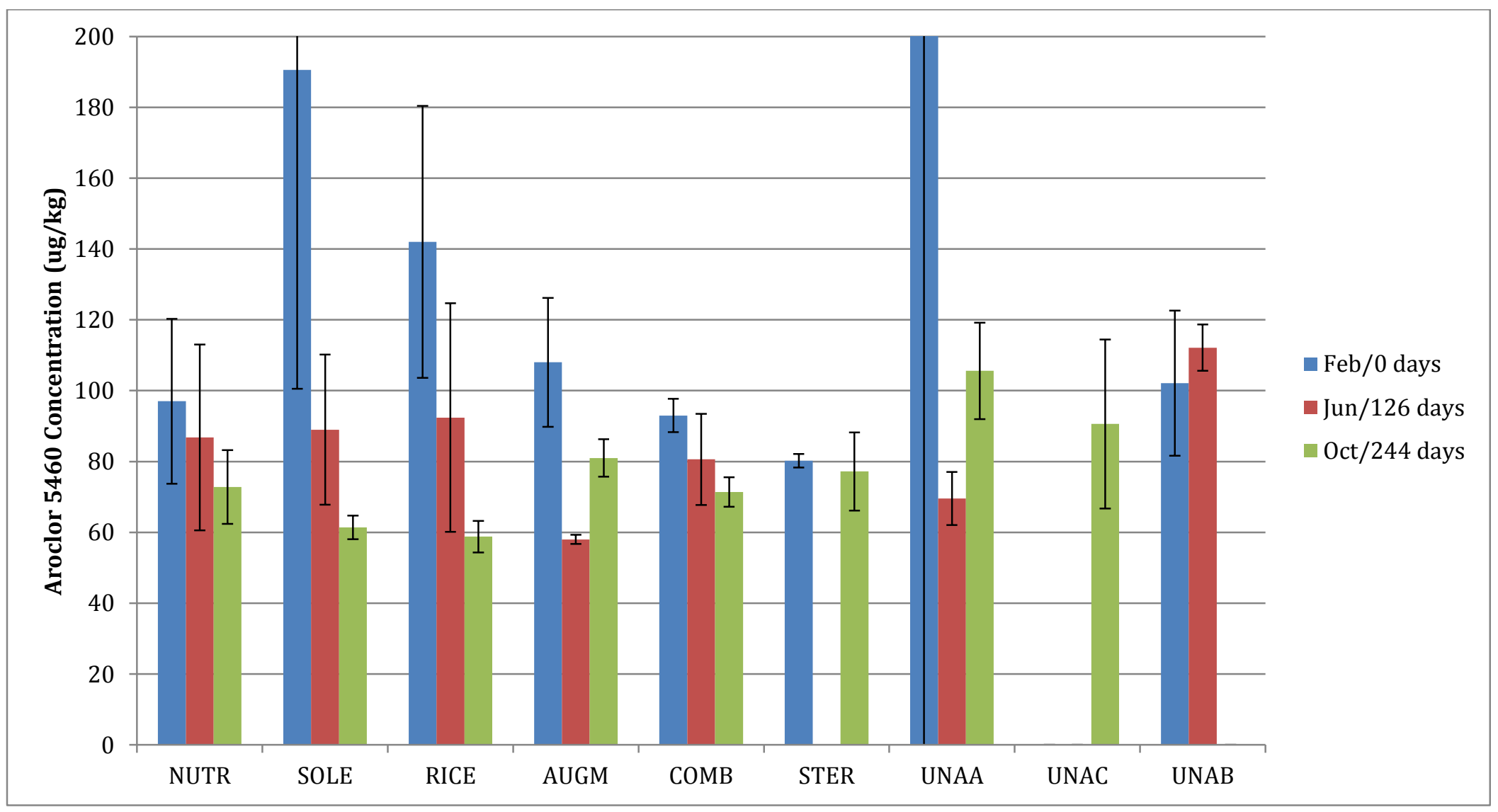

Figure 67: Truncated Aroclor 5460 concentrations during microcosm incubation 
Appendix E: Microcosm Incubator Temperature Electronic Data Sheet

\begin{tabular}{|c|c|c|c|c|c|c|c|}
\hline Sampling Date & Sampling Point & $\begin{array}{c}\text { Raw } \\
\text { Temp. }\end{array}$ & $\operatorname{deg} C$ & $\operatorname{deg} F$ & $\begin{array}{l}\text { Temp. } \\
\text { (degF) }\end{array}$ & & \\
\hline \multirow[t]{5}{*}{$5 / 1 / 2014$} & 1 & 25 & $x$ & & 77.0 & & \\
\hline & 2 & 23.6 & $x$ & & 74.5 & & \\
\hline & 3 & 24.2 & $x$ & & 75.6 & & \\
\hline & 4 & 25.5 & $x$ & & 77.9 & & \\
\hline & 5 & 22.9 & $x$ & & 73.2 & & \\
\hline Statistics & & & & Average & 75.6 & St. Dev. & 1.9 \\
\hline \multirow[t]{5}{*}{$5 / 6 / 2014$} & 1 & 19.1 & $x$ & & 66.4 & & \\
\hline & 2 & 18.2 & $x$ & & 64.8 & & \\
\hline & 3 & 20.7 & $x$ & & 69.3 & & \\
\hline & 4 & 22.8 & $x$ & & 73.0 & & \\
\hline & 5 & 18.3 & $x$ & & 64.9 & & \\
\hline Statistics & & & & Average & 67.7 & St. Dev. & 3.5 \\
\hline \multirow[t]{5}{*}{$5 / 11 / 2014$} & 1 & 26.8 & $x$ & & 80.2 & & \\
\hline & 2 & 27.1 & $x$ & & 80.8 & & \\
\hline & 3 & 27 & $x$ & & 80.6 & & \\
\hline & 4 & 26.9 & $x$ & & 80.4 & & \\
\hline & 5 & 27 & $x$ & & 80.6 & & \\
\hline Statistics & & & & Average & 80.5 & St. Dev. & 0.2 \\
\hline $5 / 16 / 2014$ & 1 & 26.7 & $x$ & & 80.1 & & \\
\hline
\end{tabular}




\begin{tabular}{|c|c|c|c|c|c|c|c|}
\hline & 2 & 26.2 & $x$ & & 79.2 & & \\
\hline & 3 & 27 & $x$ & & 80.6 & & \\
\hline & 4 & 26.5 & $x$ & & 79.7 & & \\
\hline & 5 & 28 & $x$ & & 82.4 & & \\
\hline Statistics & & & & Average & 80.4 & St. Dev. & 1.2 \\
\hline $5 / 23 / 2014$ & 1 & 27.1 & $x$ & & 80.8 & & \\
\hline & 2 & 26.8 & $x$ & & 80.2 & & \\
\hline & 3 & 26.9 & $x$ & & 80.4 & & \\
\hline & 4 & 27 & $x$ & & 80.6 & & \\
\hline & 5 & 26.6 & $x$ & & 79.9 & & \\
\hline Statistics & & & & Average & 80.4 & St. Dev. & 0.3 \\
\hline $5 / 28 / 2014$ & 1 & 26 & $x$ & & 78.8 & & \\
\hline & 2 & 25.5 & $x$ & & 77.9 & & \\
\hline & 3 & 26.2 & $x$ & & 79.2 & & \\
\hline & 4 & 26.1 & $x$ & & 79.0 & & \\
\hline & 5 & 26.7 & $x$ & & 80.1 & & \\
\hline Statistics & & & & Average & 79.0 & St. Dev. & 0.8 \\
\hline $6 / 3 / 2014$ & 1 & 74.2 & & $x$ & 74.2 & & \\
\hline & 2 & 73.9 & & $x$ & 73.9 & & \\
\hline & 3 & 74.5 & & $x$ & 74.5 & & \\
\hline & 4 & 73.7 & & $x$ & 73.7 & & \\
\hline & 5 & 75.1 & & $x$ & 75.1 & & \\
\hline Statistics & & & & Average & 74.3 & St. Dev. & 0.5 \\
\hline & & & & & & & \\
\hline 6/9/2014 & 1 & 76.2 & & $x$ & 76.2 & & \\
\hline & $\begin{array}{l}2 \\
3\end{array}$ & $\begin{array}{l}77.1 \\
75.8\end{array}$ & & $\begin{array}{l}x \\
x\end{array}$ & $\begin{array}{l}77.1 \\
75.8\end{array}$ & & \\
\hline
\end{tabular}




\begin{tabular}{|c|c|c|c|c|c|c|c|}
\hline & $\begin{array}{l}4 \\
5 \\
\end{array}$ & $\begin{array}{l}76.4 \\
76.8 \\
\end{array}$ & & $\begin{array}{l}x \\
x \\
\end{array}$ & $\begin{array}{l}76.4 \\
76.8 \\
\end{array}$ & & \\
\hline Statistics & & & & Average & 76.5 & St. Dev. & 0.5 \\
\hline $6 / 16 / 2014$ & $\begin{array}{l}1 \\
2 \\
3 \\
4 \\
5\end{array}$ & $\begin{array}{r}77.4 \\
76.6 \\
77 \\
76.8 \\
77.4\end{array}$ & & $\begin{array}{l}x \\
x \\
x \\
x \\
x\end{array}$ & $\begin{array}{l}77.4 \\
76.6 \\
77.0 \\
76.8 \\
77.4\end{array}$ & & \\
\hline Statistics & & & & Average & 77.0 & St. Dev. & 0.4 \\
\hline $6 / 28 / 2014$ & $\begin{array}{l}1 \\
2 \\
3 \\
4 \\
5 \\
\end{array}$ & $\begin{array}{l}26.2 \\
25.4 \\
26.8 \\
25.8 \\
26.6 \\
\end{array}$ & $\begin{array}{l}x \\
x \\
x \\
x \\
x \\
\end{array}$ & & $\begin{array}{l}79.2 \\
77.7 \\
80.2 \\
78.4 \\
79.9 \\
\end{array}$ & & \\
\hline Statistics & & & & Average & 79.1 & St. Dev. & 1.0 \\
\hline $6 / 30 / 2014$ & $\begin{array}{l}1 \\
2 \\
3 \\
4 \\
5 \\
\end{array}$ & $\begin{array}{r}25.4 \\
25.6 \\
25.3 \\
25.6 \\
25 \\
\end{array}$ & $\begin{array}{l}x \\
x \\
x \\
x \\
x \\
\end{array}$ & & $\begin{array}{l}77.7 \\
78.1 \\
77.5 \\
78.1 \\
77.0 \\
\end{array}$ & & \\
\hline Statistics & & & & Average & 77.7 & St. Dev. & 0.4 \\
\hline 7/7/2014 & $\begin{array}{l}1 \\
2 \\
3 \\
4 \\
5\end{array}$ & $\begin{array}{l}25.3 \\
25.7 \\
26.4 \\
25.2 \\
25.6 \\
\end{array}$ & $\begin{array}{l}x \\
x \\
x \\
x \\
x \\
\end{array}$ & & $\begin{array}{l}77.5 \\
78.3 \\
79.5 \\
77.4 \\
78.1 \\
\end{array}$ & & \\
\hline Statistics & & & & Average & 78.2 & St. Dev. & 0.9 \\
\hline $7 / 14 / 2014$ & 1 & 24 & $x$ & & 75.2 & & \\
\hline
\end{tabular}




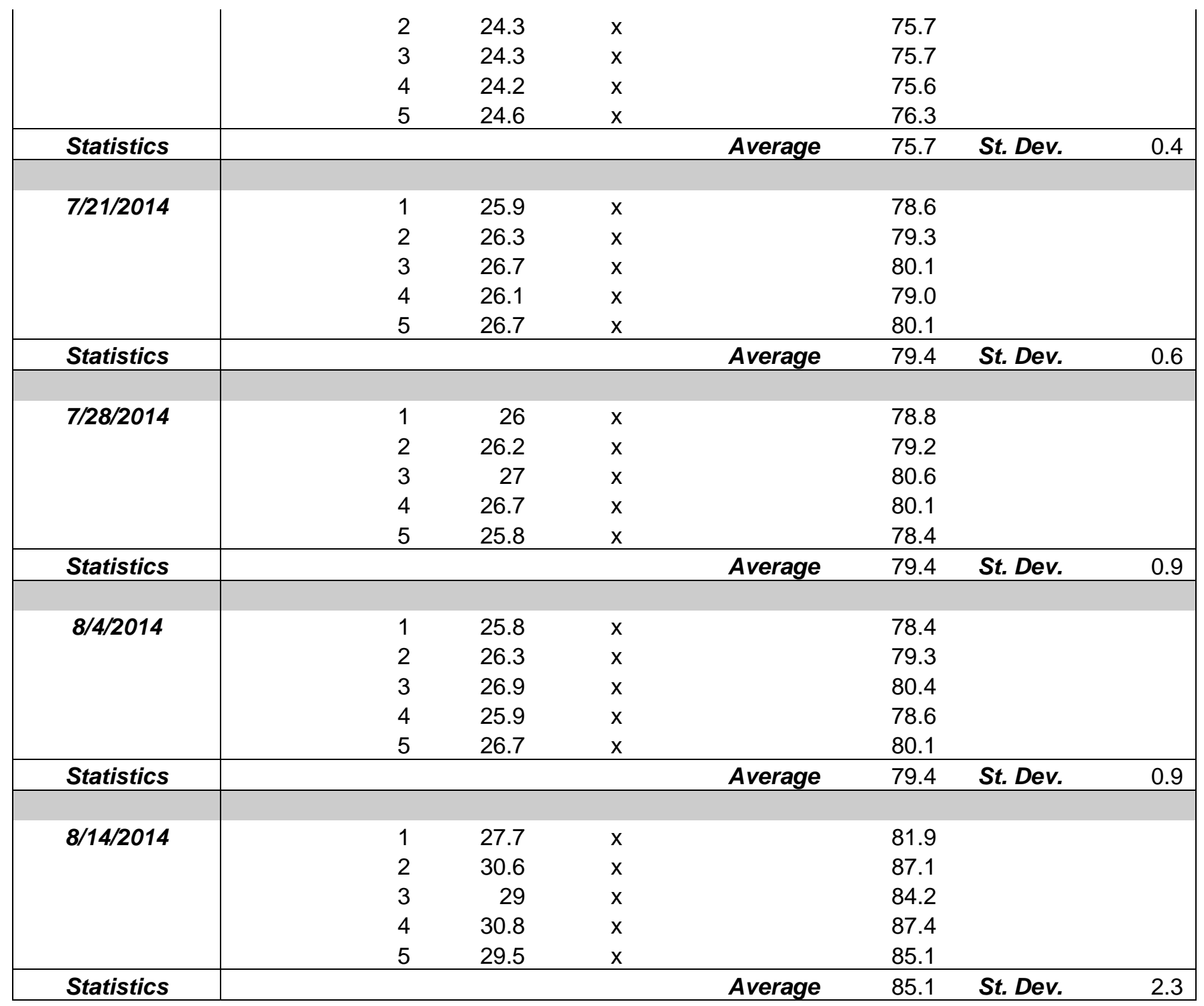




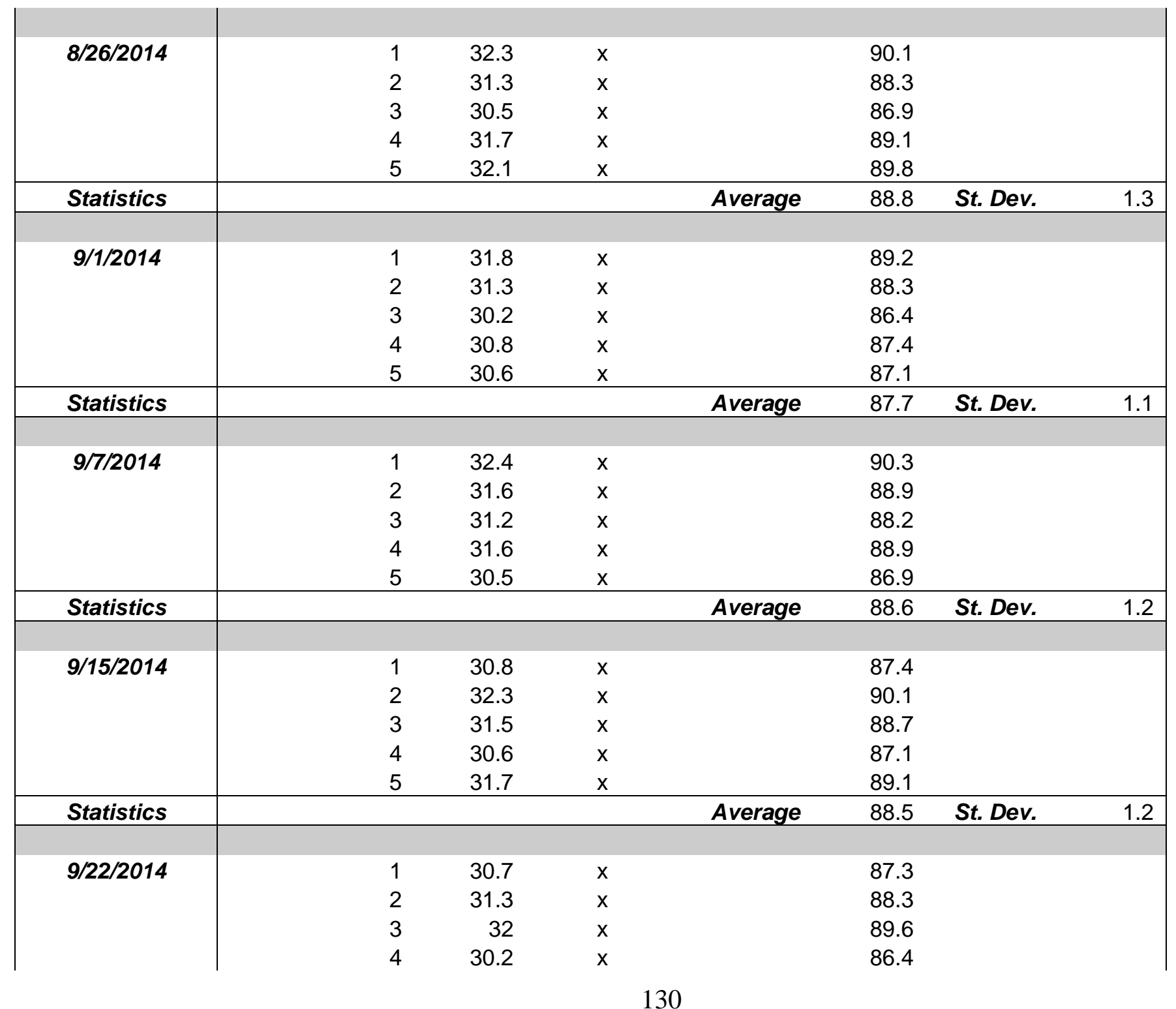




\begin{tabular}{|c|c|c|c|c|c|c|c|}
\hline & 5 & 31.7 & $x$ & & 89.1 & & \\
\hline Statistics & & & & Average & 88.1 & St. Dev. & 1.3 \\
\hline \multirow[t]{5}{*}{ 9/29/2014 } & 1 & 31.2 & $x$ & & 88.2 & & \\
\hline & 2 & 30.4 & $x$ & & 86.7 & & \\
\hline & 3 & 30.8 & $x$ & & 87.4 & & \\
\hline & 4 & 29.2 & $x$ & & 84.6 & & \\
\hline & 5 & 31.3 & $x$ & & 88.3 & & \\
\hline Statistics & & & & Average & 87.0 & St. Dev. & 1.5 \\
\hline \multirow[t]{5}{*}{$10 / 6 / 2014$} & 1 & 30.5 & $x$ & & 86.9 & & \\
\hline & 2 & 31.9 & $x$ & & 89.4 & & \\
\hline & 3 & 30.2 & $x$ & & 86.4 & & \\
\hline & 4 & 29.8 & $x$ & & 85.6 & & \\
\hline & 5 & 31.5 & $x$ & & 88.7 & & \\
\hline Statistics & & & & Average & 87.4 & St. Dev. & 1.6 \\
\hline \multirow{5}{*}{ 10/13/2014 } & & & & & & & \\
\hline & $\begin{array}{l}1 \\
2\end{array}$ & $\begin{array}{l}29.9 \\
314\end{array}$ & $\begin{array}{l}x \\
x\end{array}$ & & $\begin{array}{l}85.8 \\
88.5\end{array}$ & & \\
\hline & 3 & 29.7 & $\hat{x}$ & & 85.5 & & \\
\hline & 4 & 30.2 & $x$ & & 86.4 & & \\
\hline & 5 & 30.8 & $x$ & & 87.4 & & \\
\hline Statistics & & & & Average & 86.7 & St. Dev. & 1.3 \\
\hline \multirow[t]{5}{*}{$10 / 20 / 2014$} & 1 & 29.8 & $x$ & & 85.6 & & \\
\hline & 2 & 31.2 & $x$ & & 88.2 & & \\
\hline & 3 & 30.6 & $x$ & & 87.1 & & \\
\hline & 4 & 30.5 & $x$ & & 86.9 & & \\
\hline & 5 & 30.7 & $x$ & & 87.3 & & \\
\hline Statistics & & & & Average & 87.0 & St. Dev. & 0.9 \\
\hline \multirow[t]{2}{*}{ 10/27/2014 } & 1 & 31.7 & $x$ & & 89.1 & & \\
\hline & 2 & 30.3 & $\hat{x}$ & & 86.5 & & \\
\hline
\end{tabular}




\begin{tabular}{|c|c|c|c|c|c|c|c|}
\hline & $\begin{array}{l}3 \\
4 \\
5 \\
\end{array}$ & $\begin{array}{l}30.6 \\
30.5 \\
30.7 \\
\end{array}$ & $\begin{array}{l}x \\
x \\
x \\
\end{array}$ & & $\begin{array}{l}87.1 \\
86.9 \\
87.3 \\
\end{array}$ & & \\
\hline Statistics & & & & Average & 87.4 & St. Dev. & 1.0 \\
\hline $11 / 3 / 2014$ & $\begin{array}{l}1 \\
2 \\
3 \\
4 \\
5\end{array}$ & $\begin{array}{l}25.2 \\
24.7 \\
23.9 \\
24.6 \\
24.2\end{array}$ & $\begin{array}{l}x \\
x \\
x \\
x \\
x\end{array}$ & & $\begin{array}{l}77.4 \\
76.5 \\
75.0 \\
76.3 \\
75.6\end{array}$ & & \\
\hline \multirow[t]{2}{*}{ Statistics } & & & & Average & 76.1 & St. Dev. & 0.9 \\
\hline & & & & $\begin{array}{l}\text { Overall A } \\
\text { Overall S }\end{array}$ & ge & & \begin{tabular}{|l|}
1.4 \\
5.6
\end{tabular} \\
\hline
\end{tabular}


Appendix F: Statistics: Effect of Treatment on Changes in Soil A COIs

General Linear Model: PAHs (ug/kg) versus Treatment, Replicate

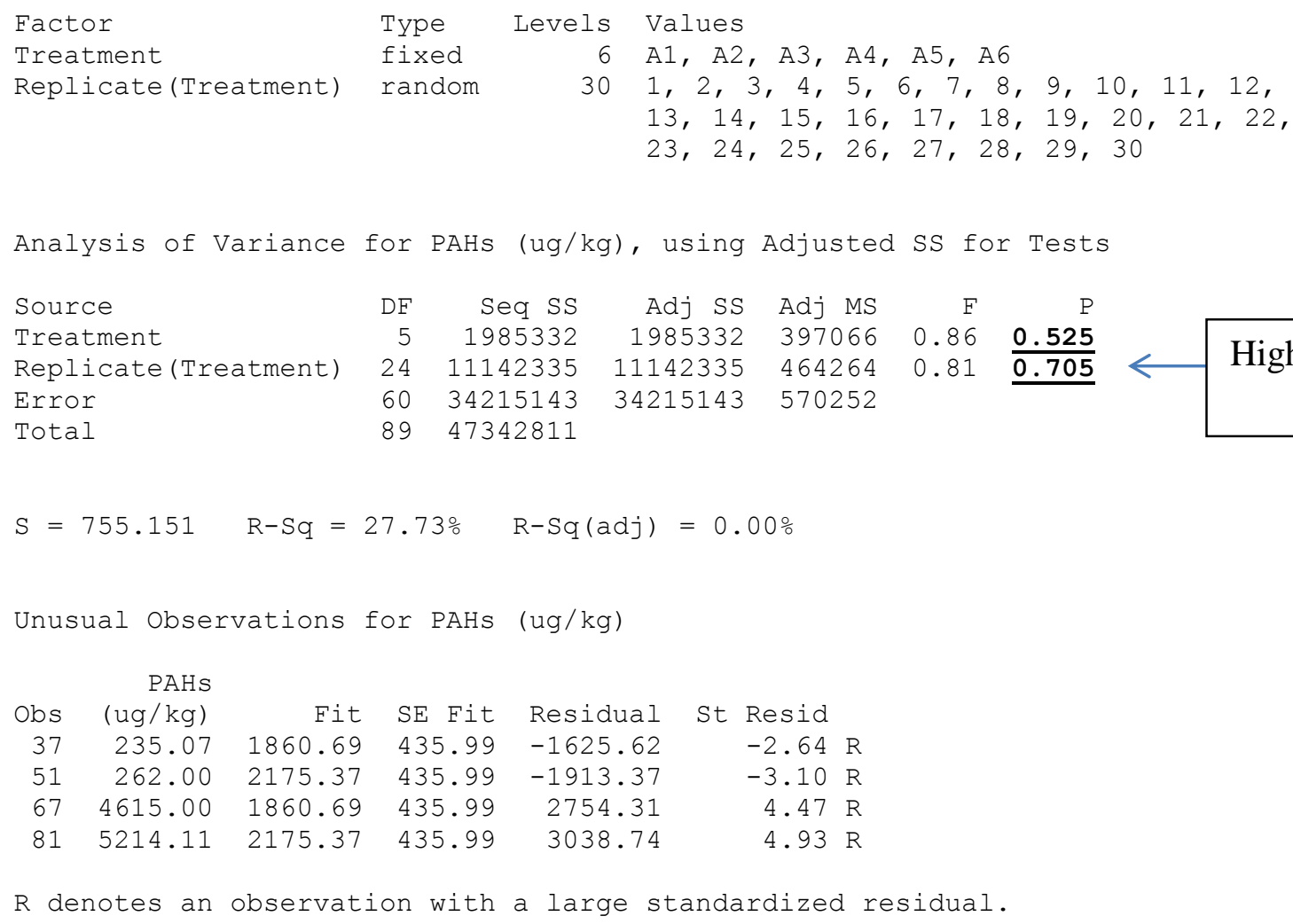

Residual Plots for PAHs (ug/kg) 


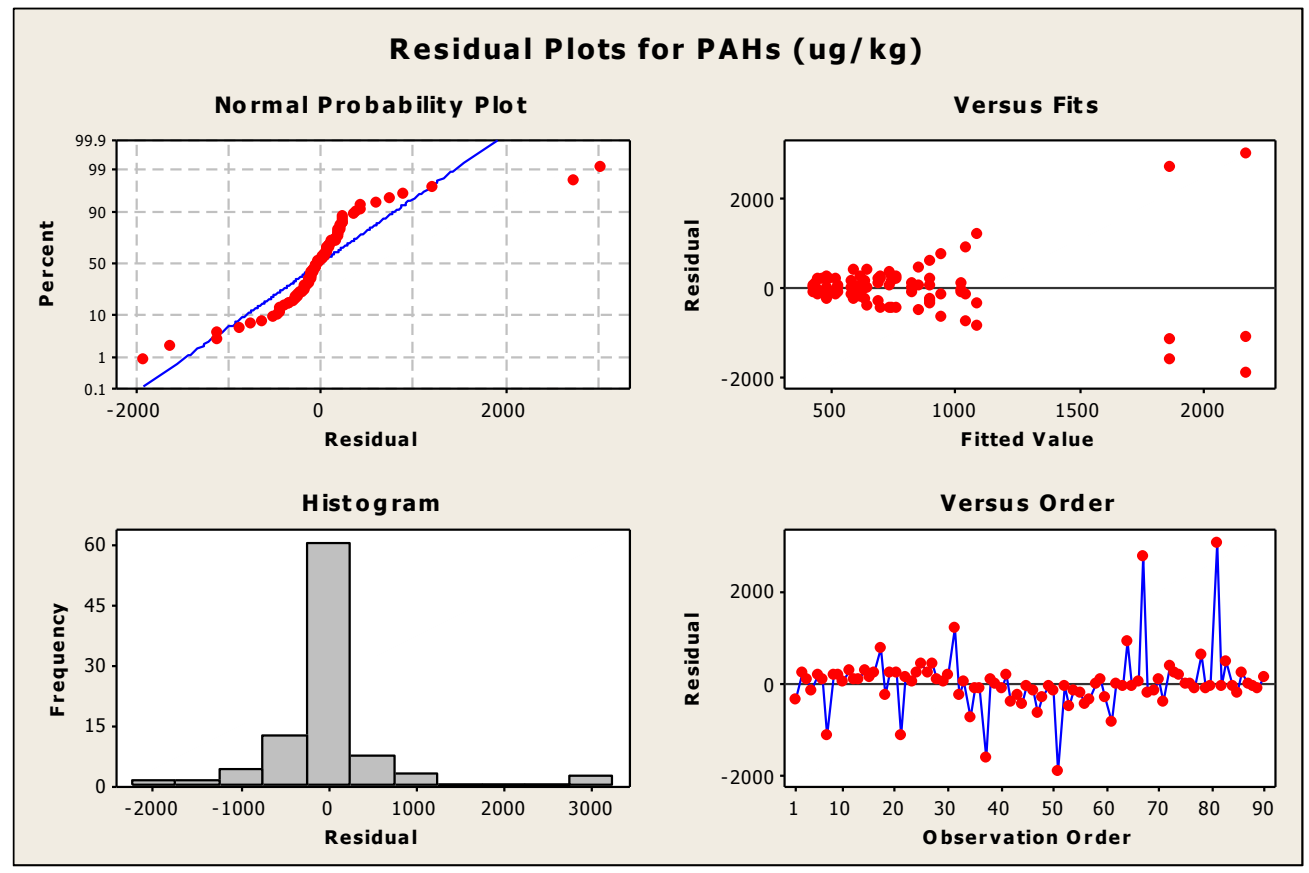

Fanning. Not
straight
probability plot.
Probably need to
take a log of fits
to see if we can
even out the
variance a bit.
S-shaped normal

$\log \mathrm{PAHs}$

\section{General Linear Model: log(PAH) versus Treatment, Replicate}

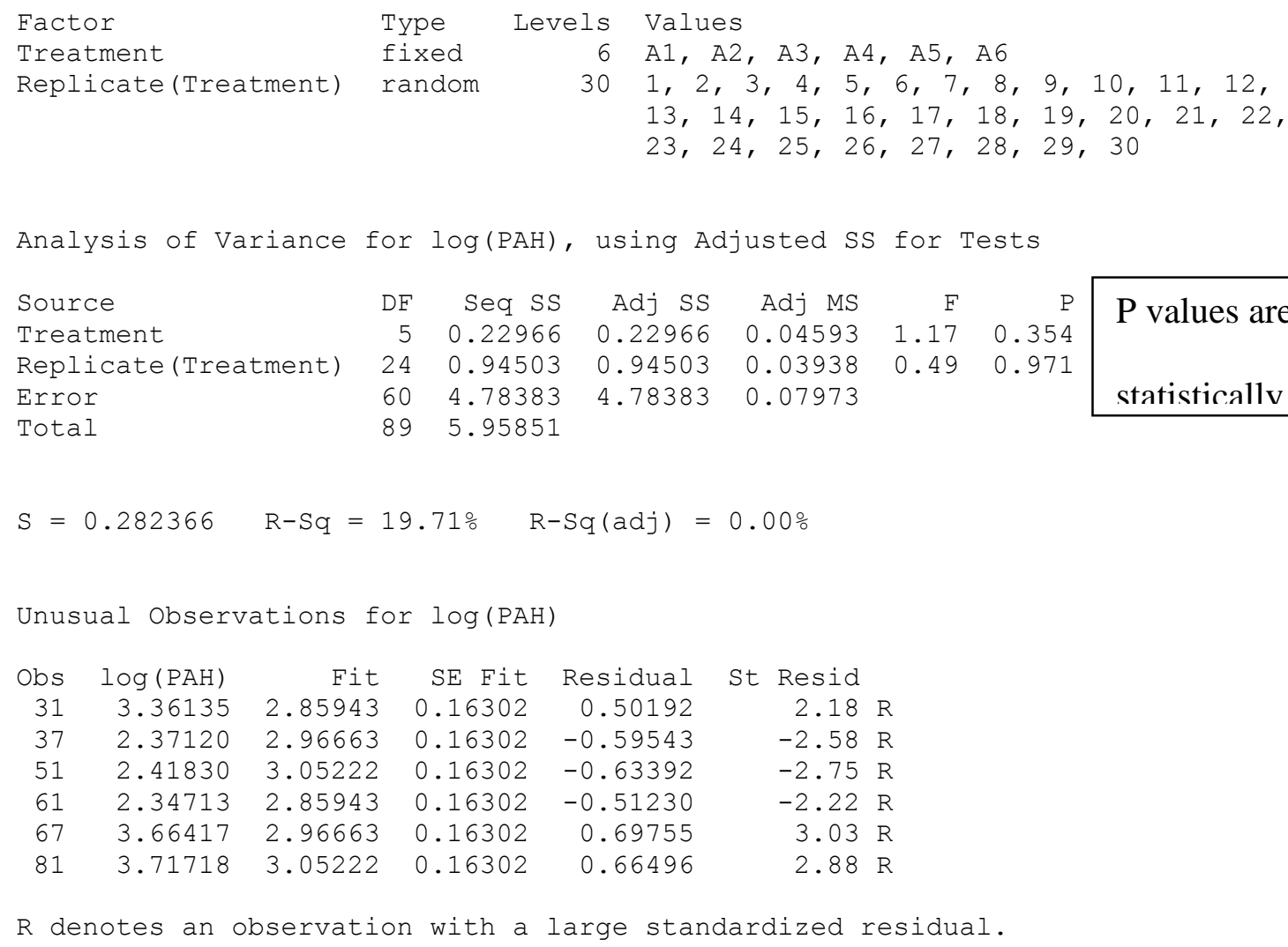




\section{Residual Plots for log(PAH)}

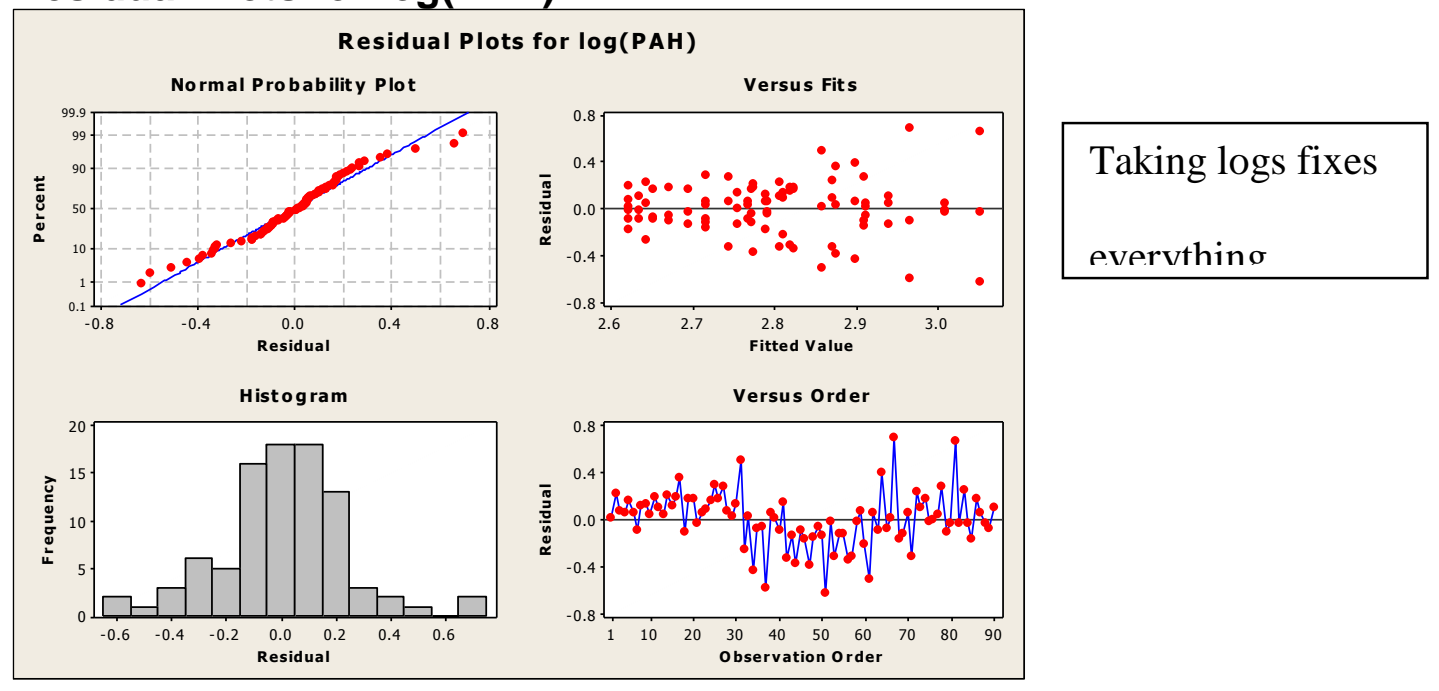

Dioxins

\section{General Linear Model: Dioxins (ng/kg) versus Treatment, Replicate}

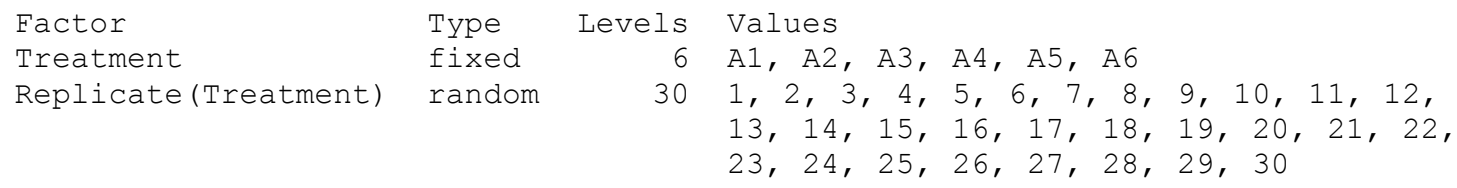

$\begin{array}{rrrrrrl} & \text { Dioxins } & & & & & \\ \text { Obs } & (\text { ng/kg) } & \text { Fit } & \text { SE Fit } & \text { Residual } & \text { St Resid } & \\ 17 & 206618 & 122788 & 13894 & 83830 & 4.27 & \text { R } \\ 33 & 80074 & 140004 & 13894 & -59930 & -3.05 & R \\ 63 & 229423 & 140004 & 13894 & 89419 & 4.55 & R \\ 77 & 77292 & 122788 & 13894 & -45496 & -2.32 & R\end{array}$

$\mathrm{R}$ denotes an observation with a large standardized residual. 


\section{Residual Plots for Dioxins (ng/kg)}

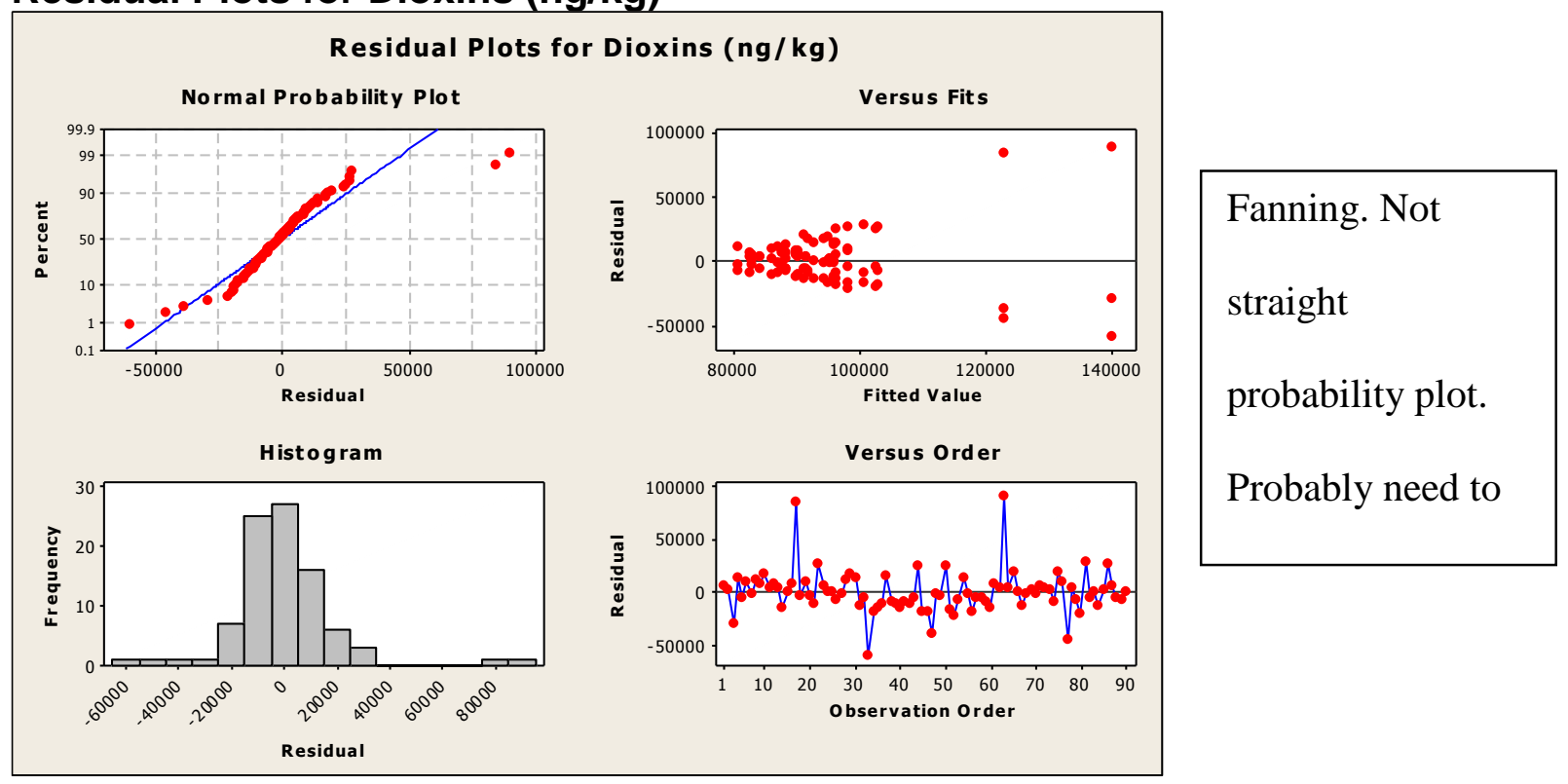

\section{$\log$ Dioxins}

\section{General Linear Model: log(Dioxins) versus Treatment, Replicate}

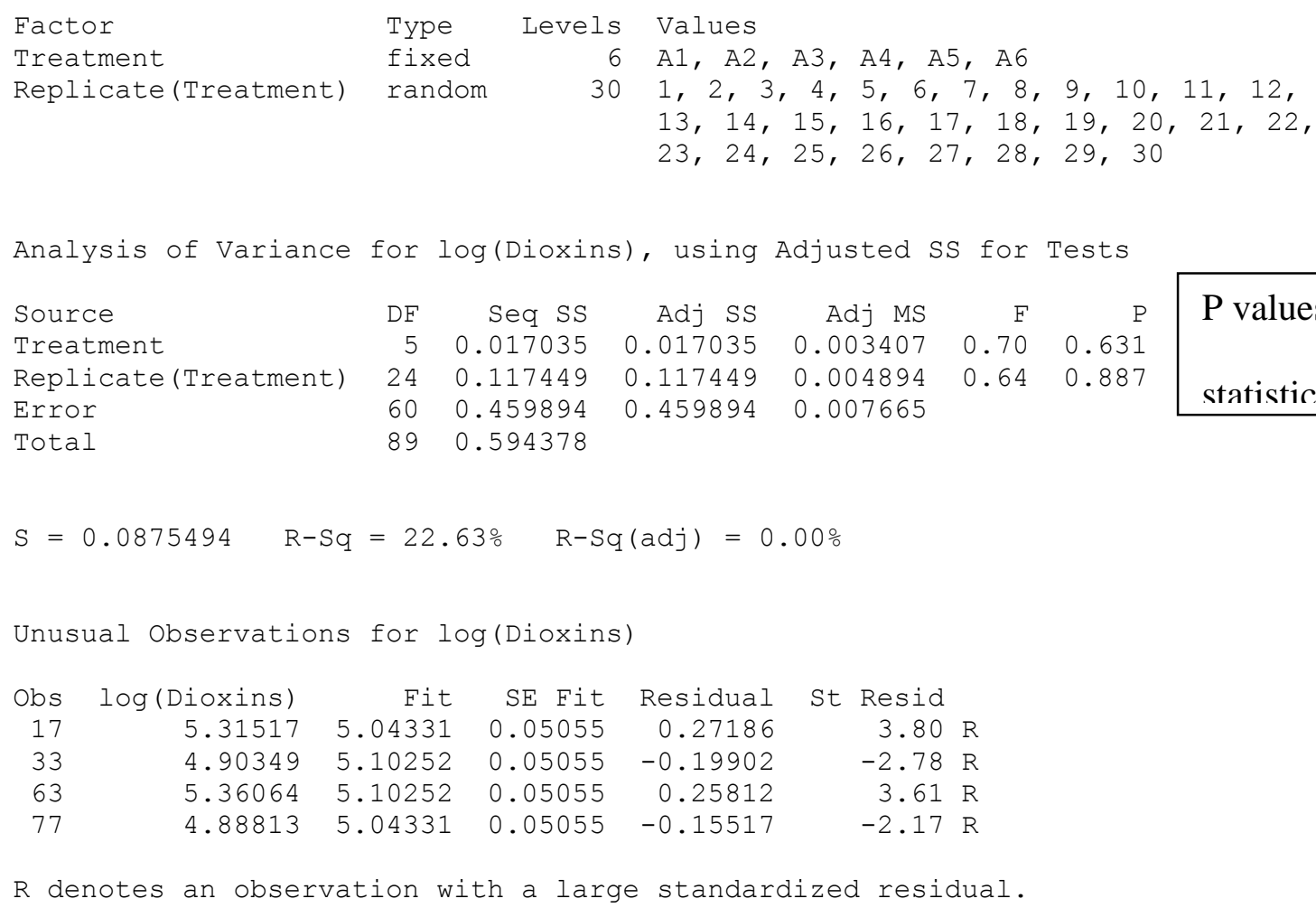

$\begin{array}{rrrrrr}\text { Obs } & \text { log(Dioxins) } & \text { Fit } & \text { SE Fit } & \text { Residual } & \text { St Resid } \\ 17 & 5.31517 & 5.04331 & 0.05055 & 0.27186 & 3.80 \mathrm{R} \\ 33 & 4.90349 & 5.10252 & 0.05055 & -0.19902 & -2.78 \mathrm{R} \\ 63 & 5.36064 & 5.10252 & 0.05055 & 0.25812 & 3.61 \mathrm{R} \\ 77 & 4.88813 & 5.04331 & 0.05055 & -0.15517 & -2.17 \mathrm{R}\end{array}$

$\mathrm{R}$ denotes an observation with a large standardized residual. 


\section{Residual Plots for log(Dioxins)}

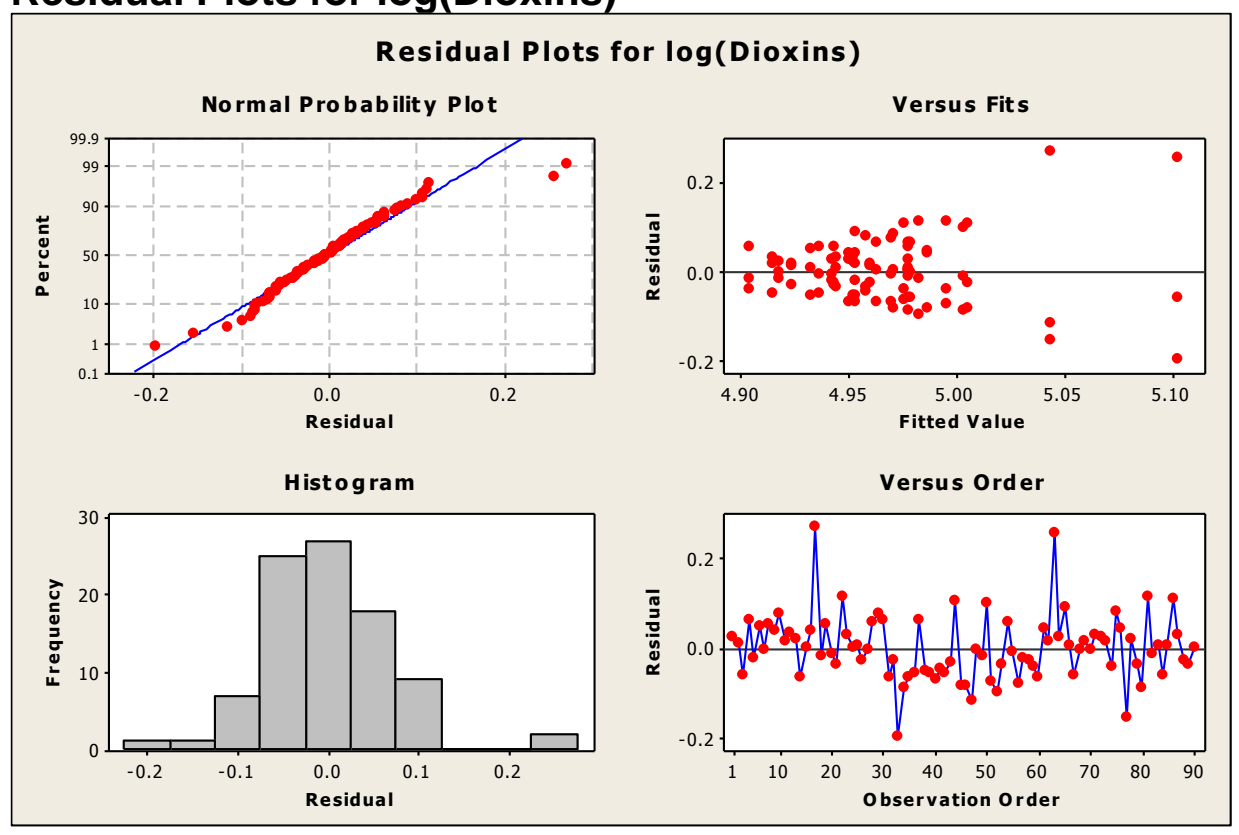

Fanning. straight probability plot.

Probably need to take a square root of responses to see if we can even nut the vercus fits

Sqrt (Dioxins)

\section{General Linear Model: sqrt(Dioxins) versus Treatment, Replicate}

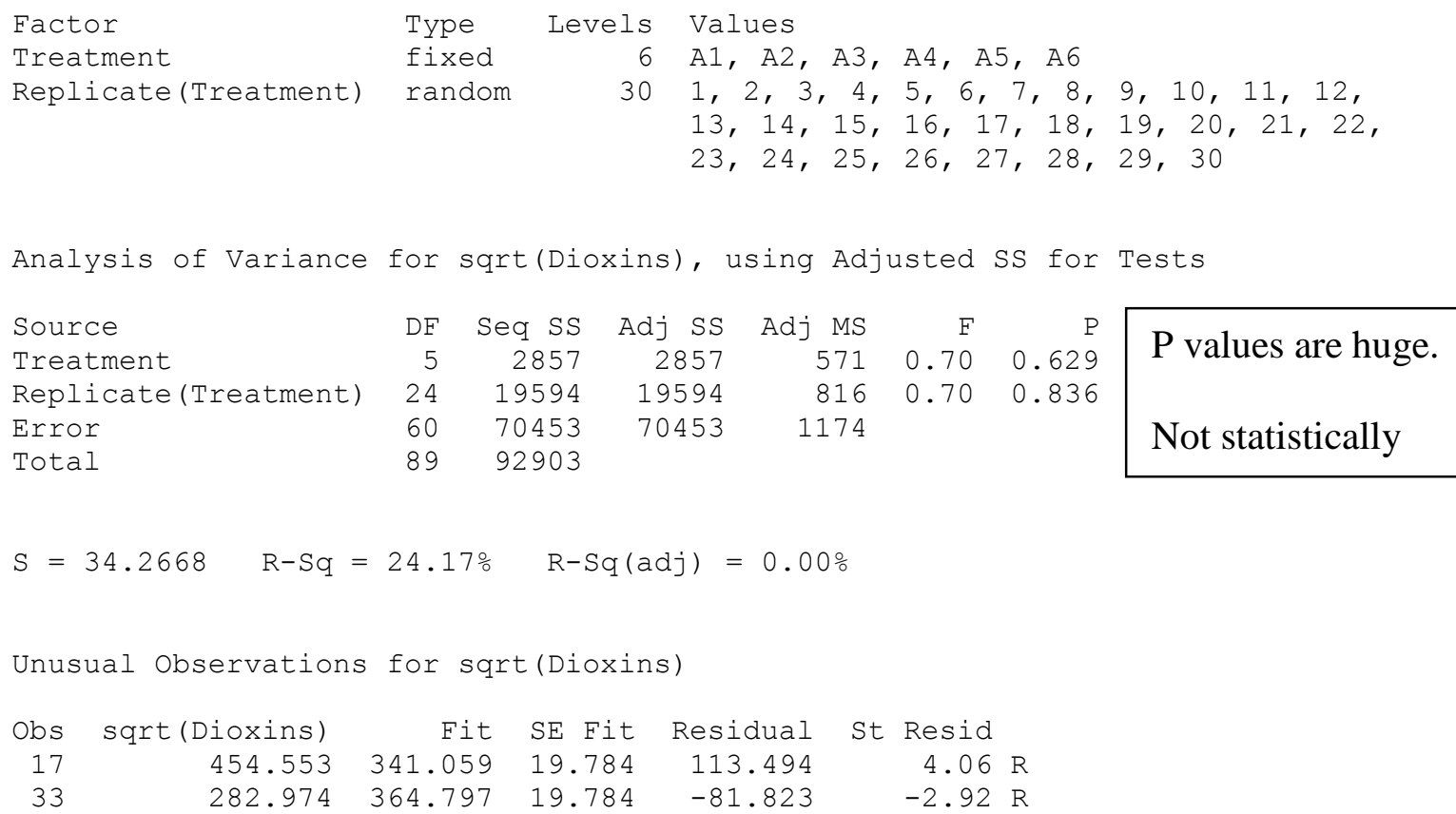




$\begin{array}{lllllrl}63 & 478.981 & 364.797 & 19.784 & 114.184 & 4.08 & R \\ 77 & 278.014 & 341.059 & 19.784 & -63.045 & -2.25 & R\end{array}$

$\mathrm{R}$ denotes an observation with a large standardized residual.

\section{Residual Plots for sqrt(Dioxins)}

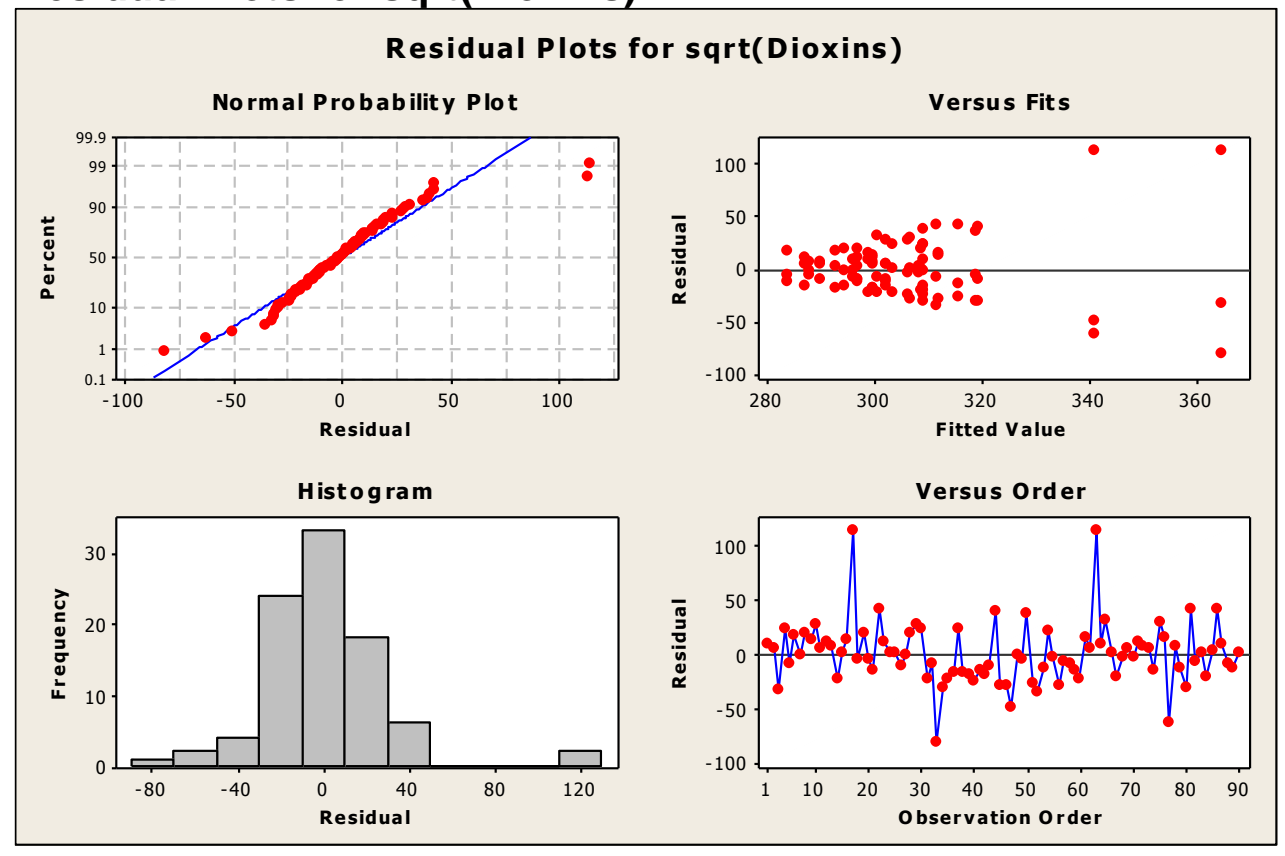

Still fanning.

Iono what the

\section{PCBs}

\section{General Linear Model: PCBs (ug/kg) versus Treatment, Replicate}

Factor

Treatment

Replicate (Treatment)

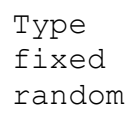

Analysis of Variance for PCBs (ug/kg), using Adjusted Ss for Tests

\begin{tabular}{|c|c|c|c|c|c|c|c|}
\hline Source & $\mathrm{DF}$ & Seq SS & Adj $S S$ & Adj MS & $\mathrm{F}$ & $\mathrm{P}[$ & \\
\hline Treatment & 5 & 8437177 & 8437177 & 1687435 & 1.05 & 0.411 & $P$ values are \\
\hline Replicate (Treatment) & 24 & 38525024 & 38525024 & 1605209 & 0.97 & 0.513 & \\
\hline Error & 60 & 99050933 & 99050933 & 1650849 & & & huge Not \\
\hline Total & 89 & 146013134 & & & & & \\
\hline
\end{tabular}

$S=1284.85 \quad R-S q=32.16 \% \quad R-S q(\operatorname{adj})=0.00 \%$

Unusual Observations for PCBs (ug/kg) 


\begin{tabular}{rrrrrr}
\multicolumn{7}{c}{ PCBs } & & & & \\
Obs & $($ ug/kg) & Fit & SE Fit & Residual & St Resid \\
27 & 12400.0 & 4306.3 & 741.8 & 8093.7 & 7.72 R \\
57 & 272.0 & 4306.3 & 741.8 & -4034.3 & $-3.85 \mathrm{R}$ \\
87 & 247.0 & 4306.3 & 741.8 & -4059.3 & $-3.87 \mathrm{R}$
\end{tabular}

$\mathrm{R}$ denotes an observation with a large standardized residual.

\section{Residual Plots for PCBs (ug/kg)}

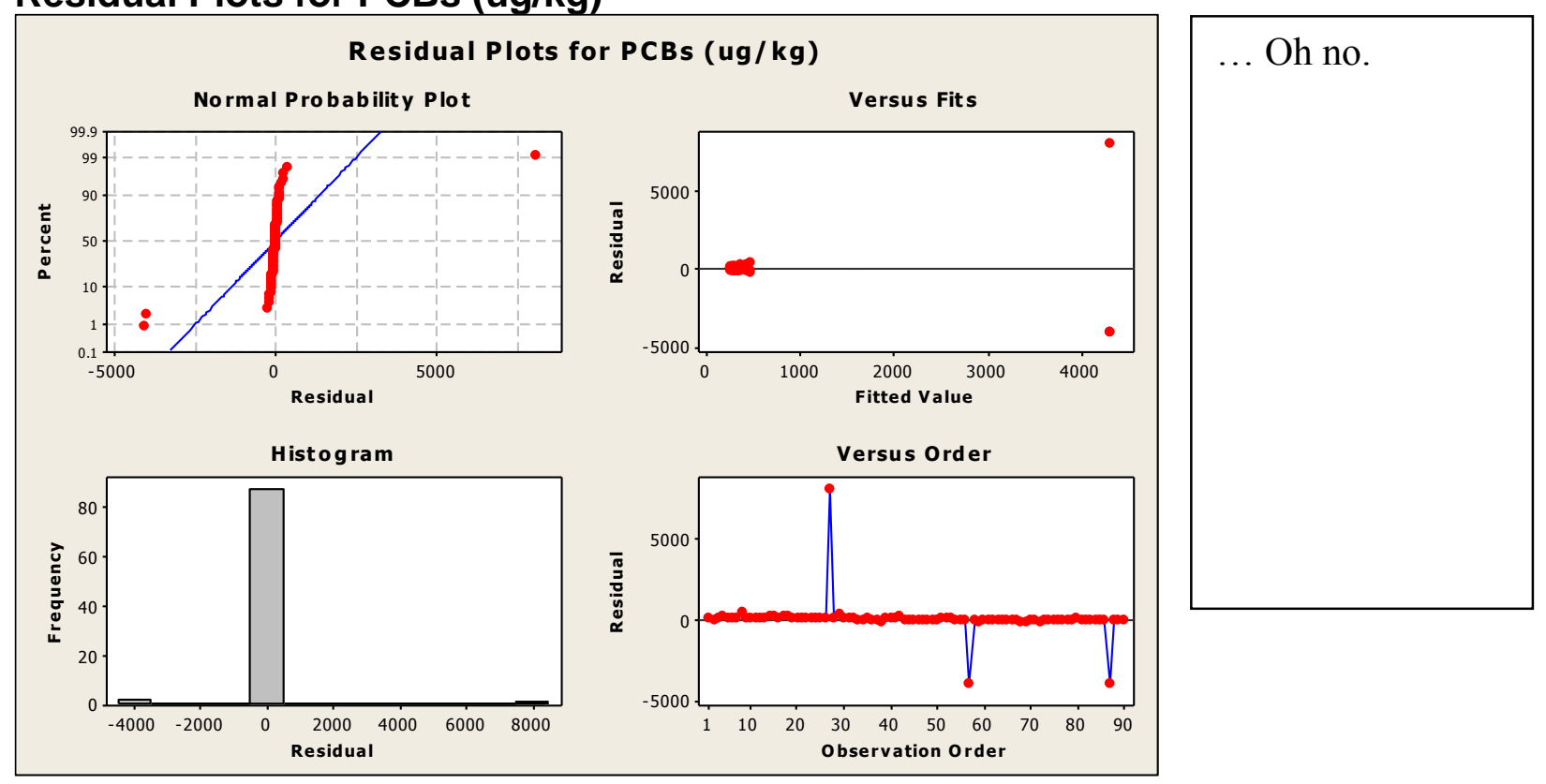

\section{$\log (\mathrm{PCBS})$}

\section{General Linear Model: $\log (\mathrm{PCBs})$ versus Treatment, Replicate}

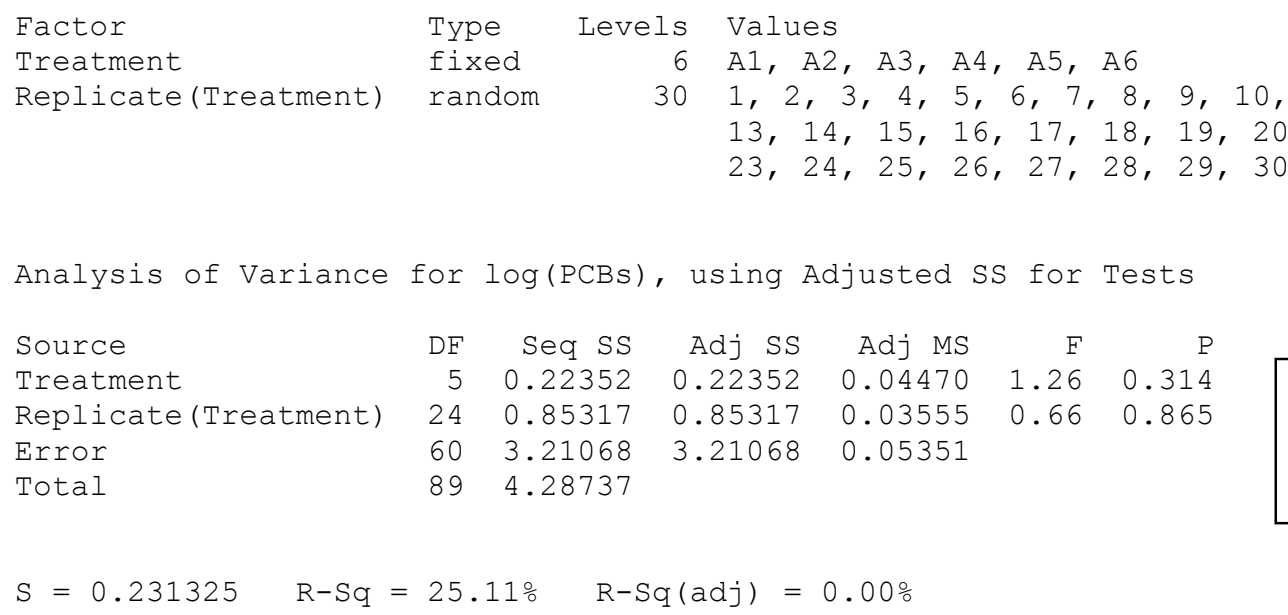


Unusual Observations for $\log (\mathrm{PCBS})$

$\begin{array}{rrrrrrr}\text { Obs } & \text { log(PCBS) } & \text { Fit } & \text { SE Fit } & \text { Residual } & \text { St Resid } \\ 27 & 4.09342 & 2.97356 & 0.13356 & 1.11986 & 5.93 & R \\ 57 & 2.43457 & 2.97356 & 0.13356 & -0.53899 & -2.85 & R \\ 87 & 2.39270 & 2.97356 & 0.13356 & -0.58087 & -3.08 & R\end{array}$

$\mathrm{R}$ denotes an observation with a large standardized residual.

\section{Residual Plots for log(PCBs)}

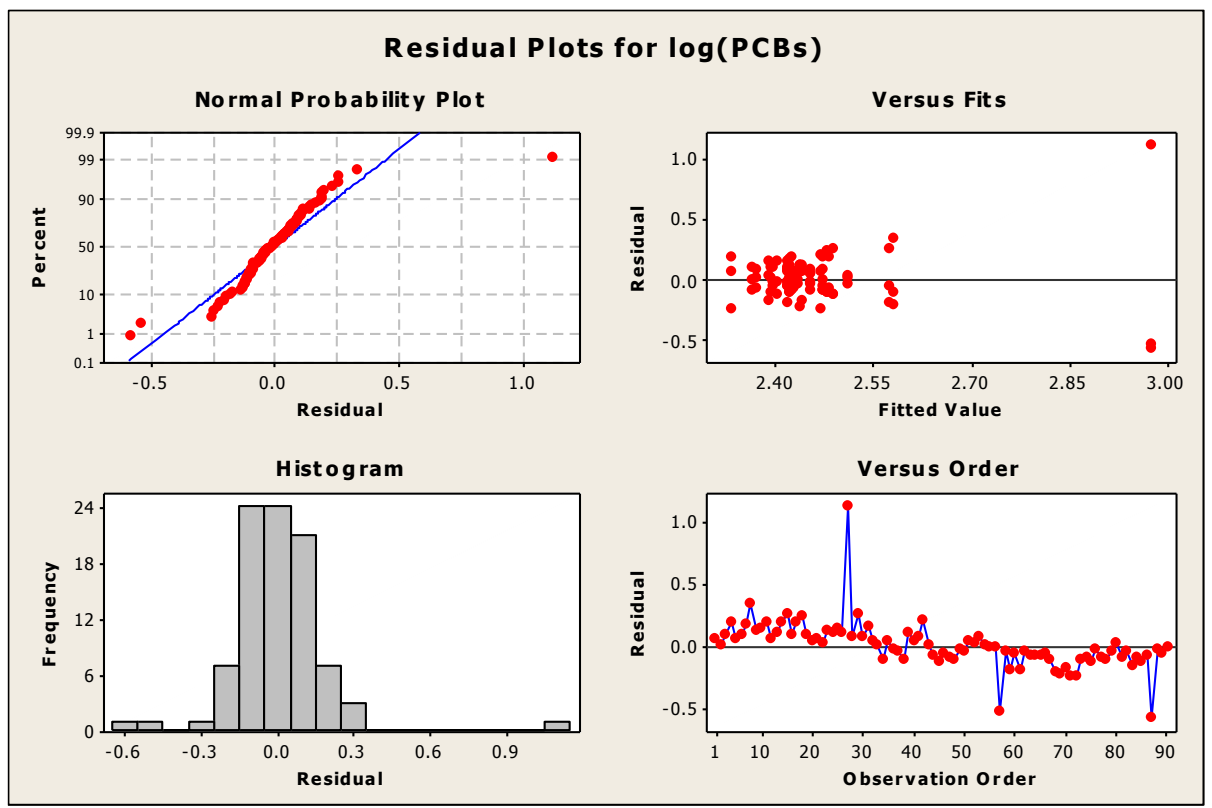

Better normal prob plot. Take sqrt to see if we can even out versus fits.

\section{$\operatorname{Sqrt}(\mathrm{PCBs})$}

\section{General Linear Model: sqrt(PCBs) versus Treatment, Replicate}

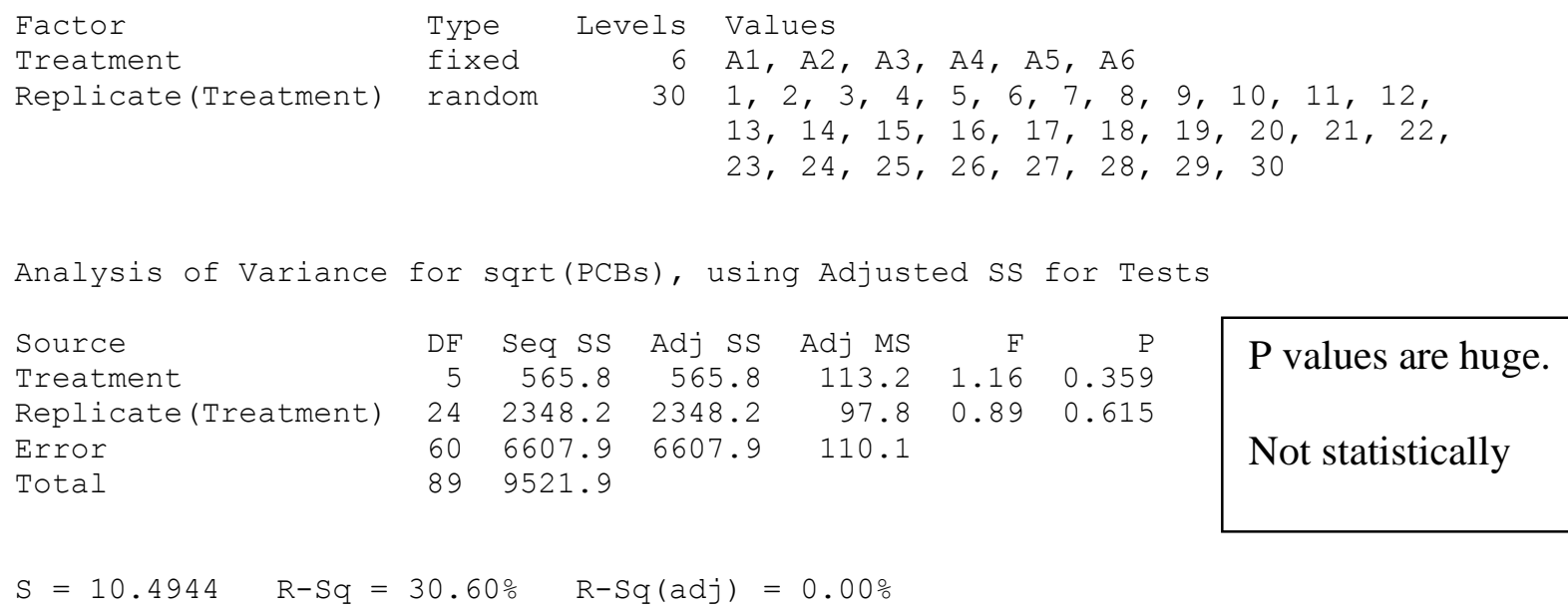




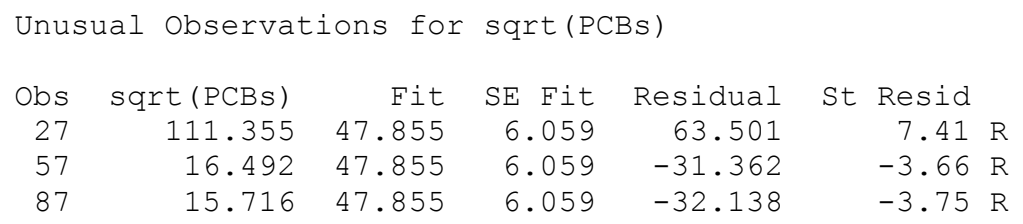

$\mathrm{R}$ denotes an observation with a large standardized residual.

\section{Residual Plots for sqrt(PCBs)}

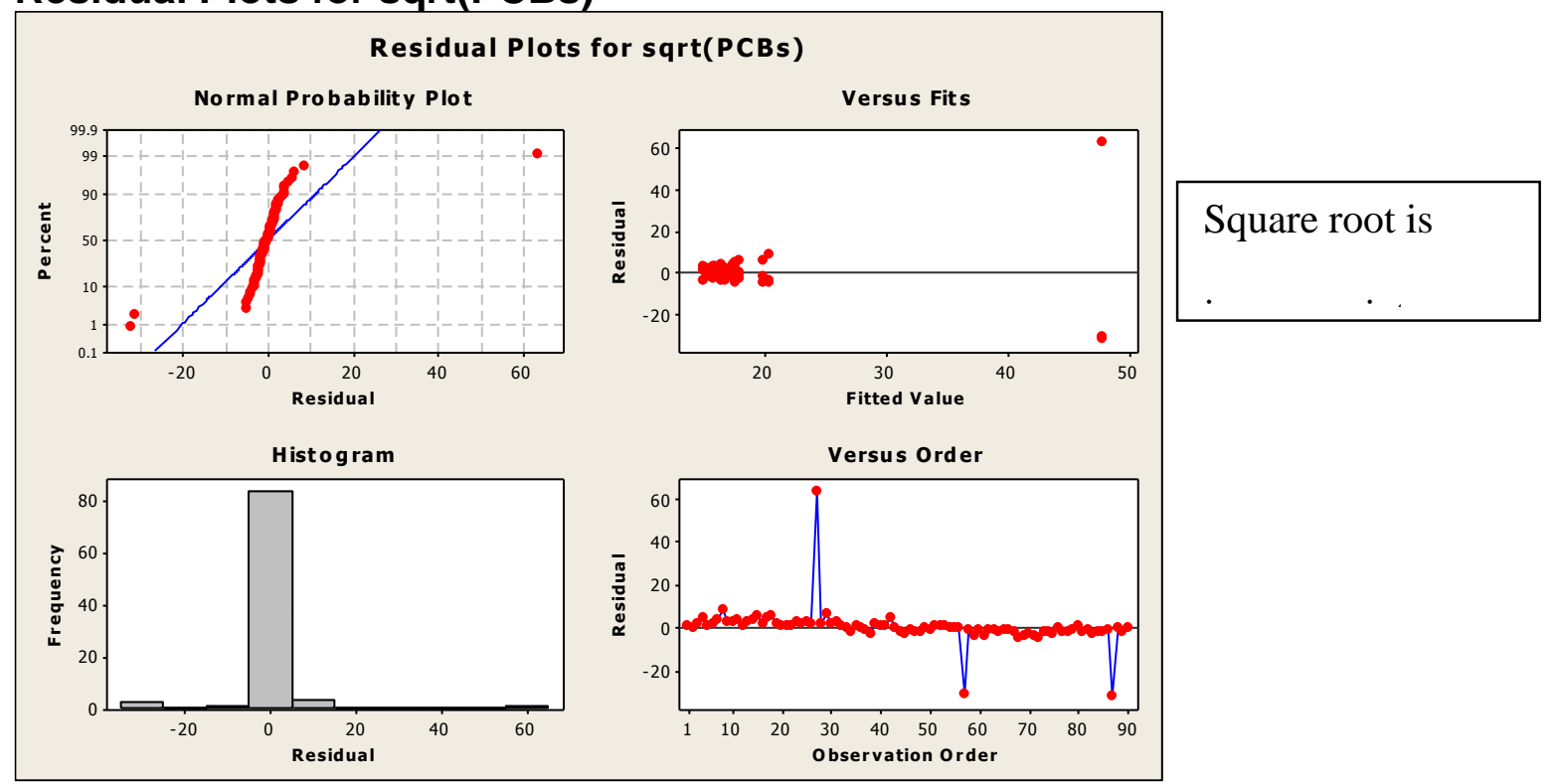

Total EFH (C8-C40) (excluding A2 and A5 because no final measurement)

\section{General Linear Model: Total EFH (mg/kg) versus Treatment, Replicate}

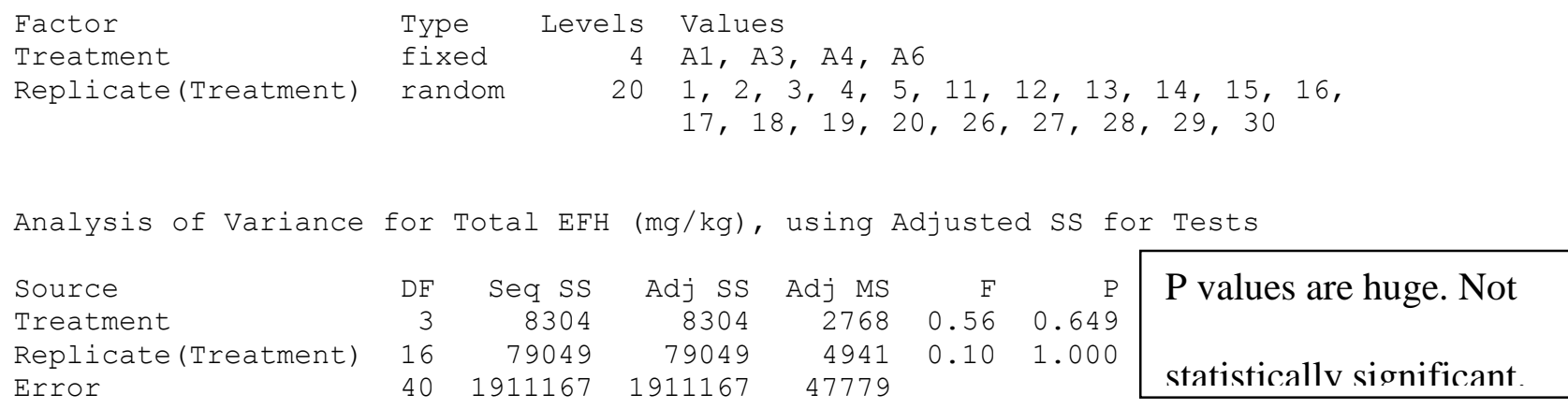




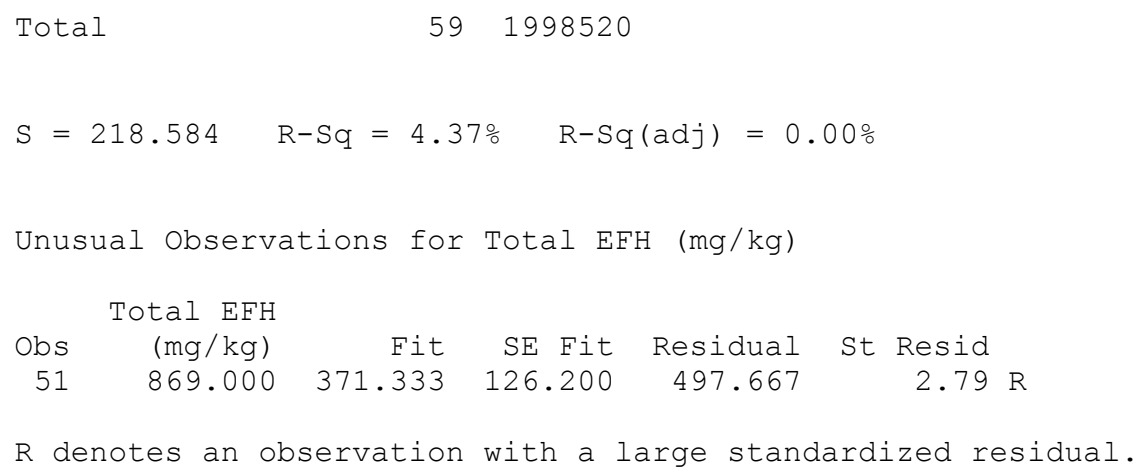

\section{Residual Plots for Total EFH (mg/kg)}

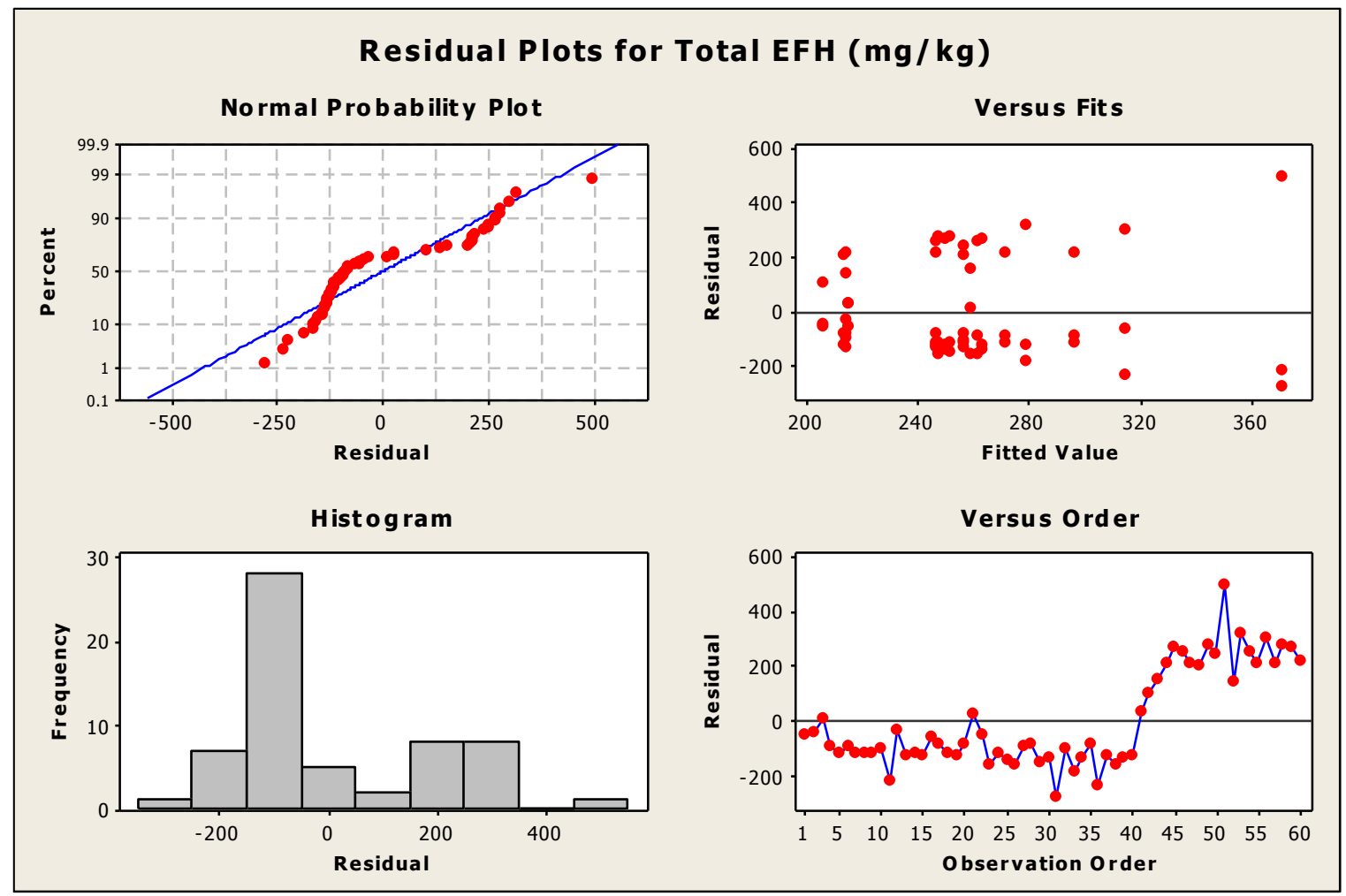

$\log ($ Total EFH)

General Linear Model: log(Total EFH) versus Treatment, Replicate

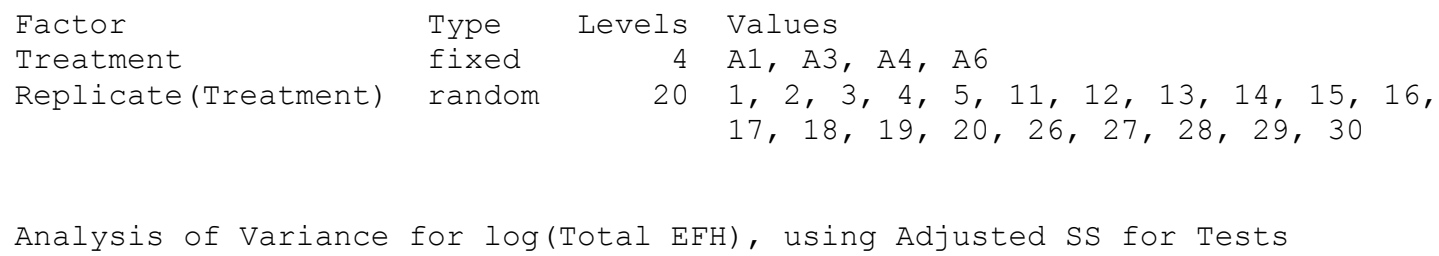




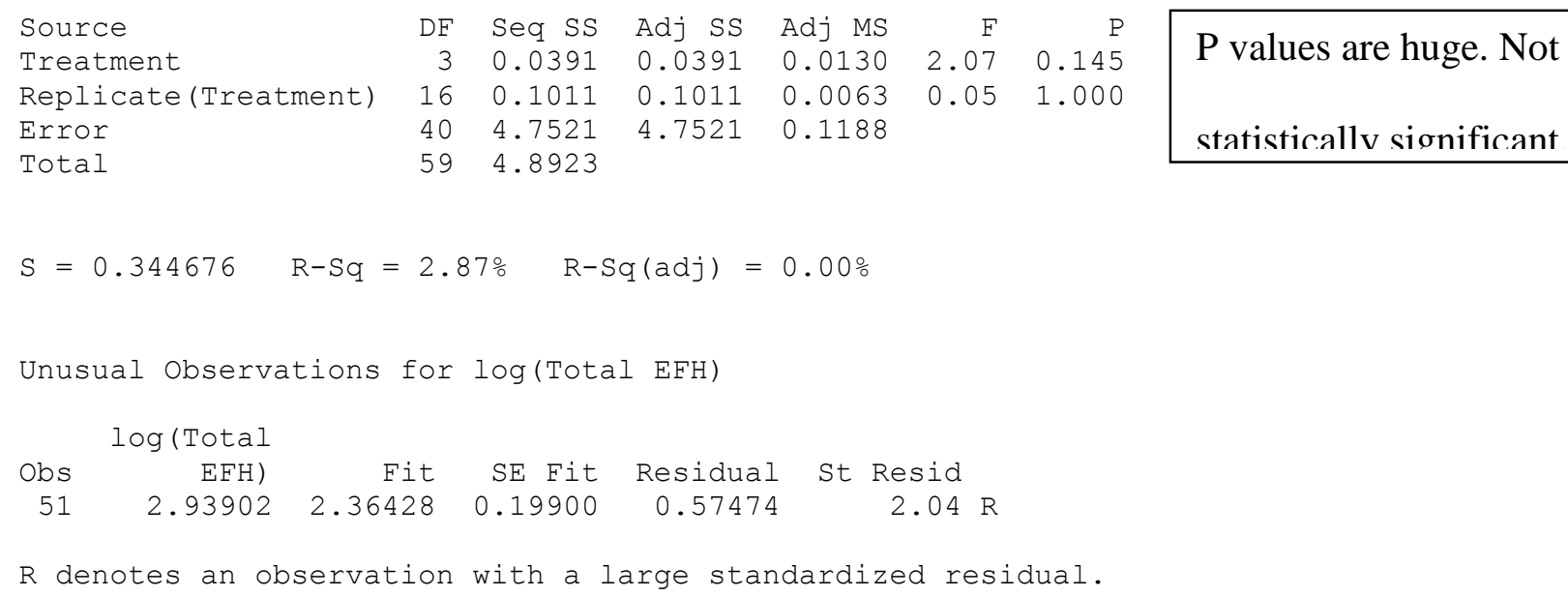

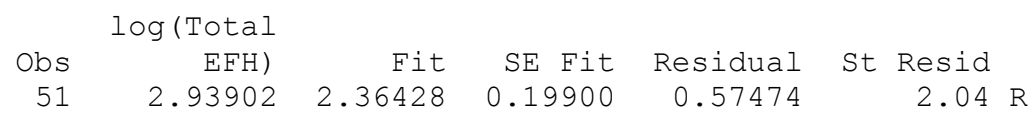

$\mathrm{R}$ denotes an observation with a large standardized residual.

\section{Residual Plots for log(Total EFH)}

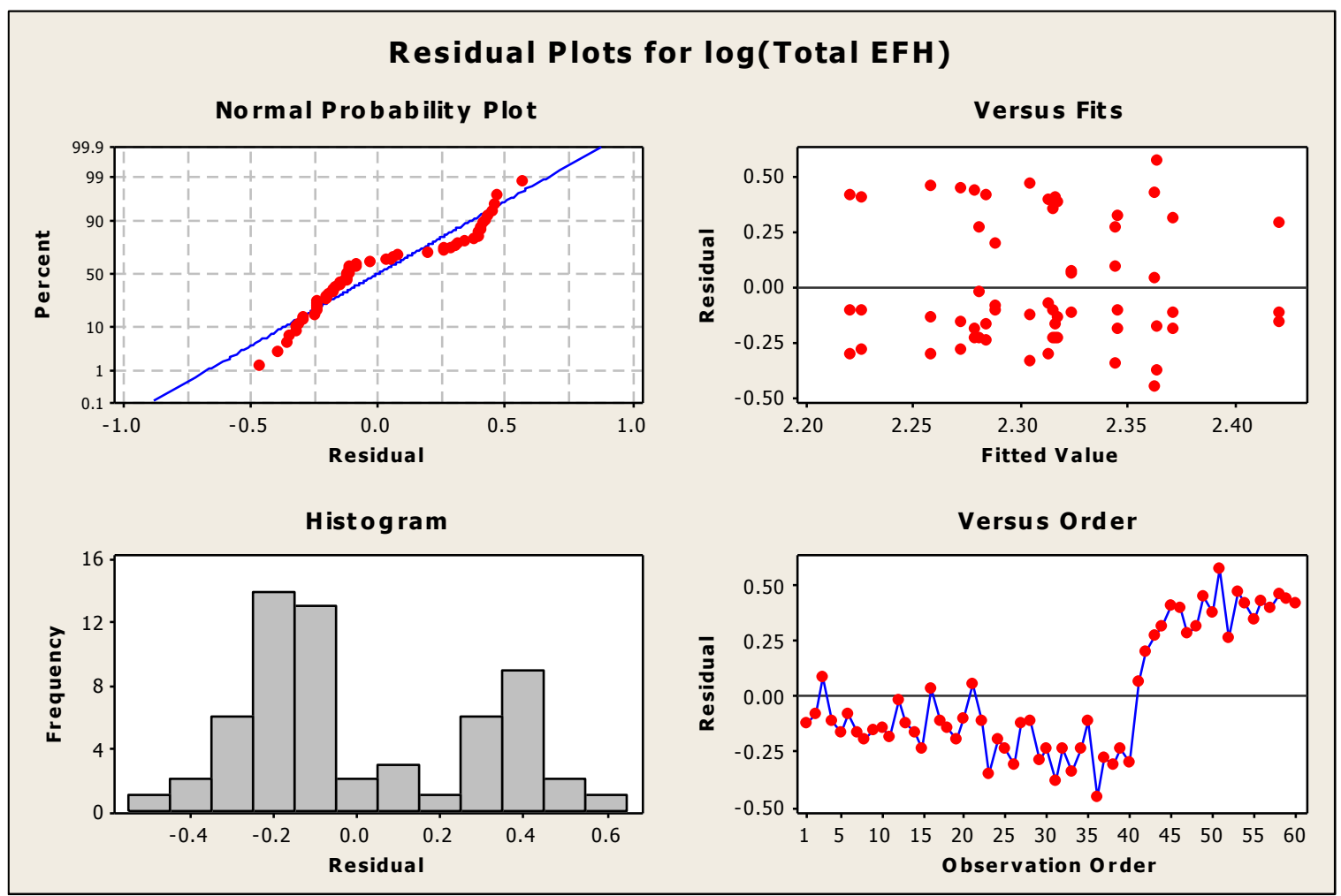

General Linear Model: TCDD TEQ (ng/kg) versus Treatment, Replicate

Factor

Treatment

Replicate (Treatment)

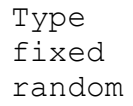

Levels

$6 \mathrm{~A} 1, \mathrm{~A} 2, \mathrm{~A} 3, \mathrm{~A} 4, \mathrm{~A} 5, \mathrm{~A} 6$

$301,2,3,4,5,6,7,8,9,10,11,12$,

$13,14,15,16,17,18,19,20,21,22$,

$23,24,25,26,27,28,29,30$ 
Analysis of Variance for TCDD TEQ (ng/kg), using Adjusted SS for Tests

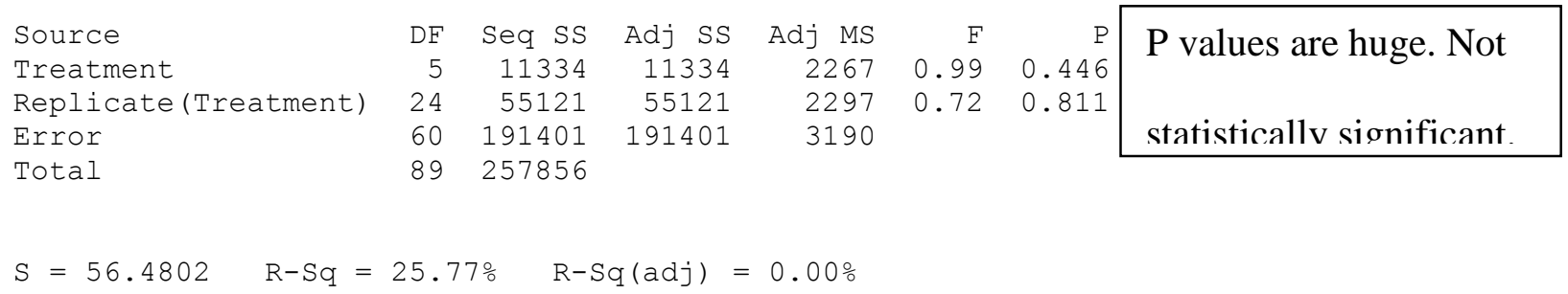

Unusual Observations for TCDD TEQ (ng/kg)

\begin{tabular}{rrrrrr}
\multicolumn{7}{c}{ TCDD TEQ } & & & \\
Obs & $($ ng/kg) & Fit & SE Fit & Residual & St Resid \\
17 & 575.000 & 362.000 & 32.609 & 213.000 & $4.62 \mathrm{R}$ \\
33 & 260.000 & 382.667 & 32.609 & -122.667 & $-2.66 \mathrm{R}$ \\
47 & 244.000 & 362.000 & 32.609 & -118.000 & $-2.56 \mathrm{R}$ \\
63 & 597.000 & 382.667 & 32.609 & 214.333 & $4.65 \mathrm{R}$ \\
77 & 267.000 & 362.000 & 32.609 & -95.000 & $-2.06 \mathrm{R}$ \\
81 & 385.000 & 292.667 & 32.609 & 92.333 & $2.00 \mathrm{R}$
\end{tabular}

$\mathrm{R}$ denotes an observation with a large standardized residual.

\section{Residual Plots for TCDD TEQ (ng/kg)}

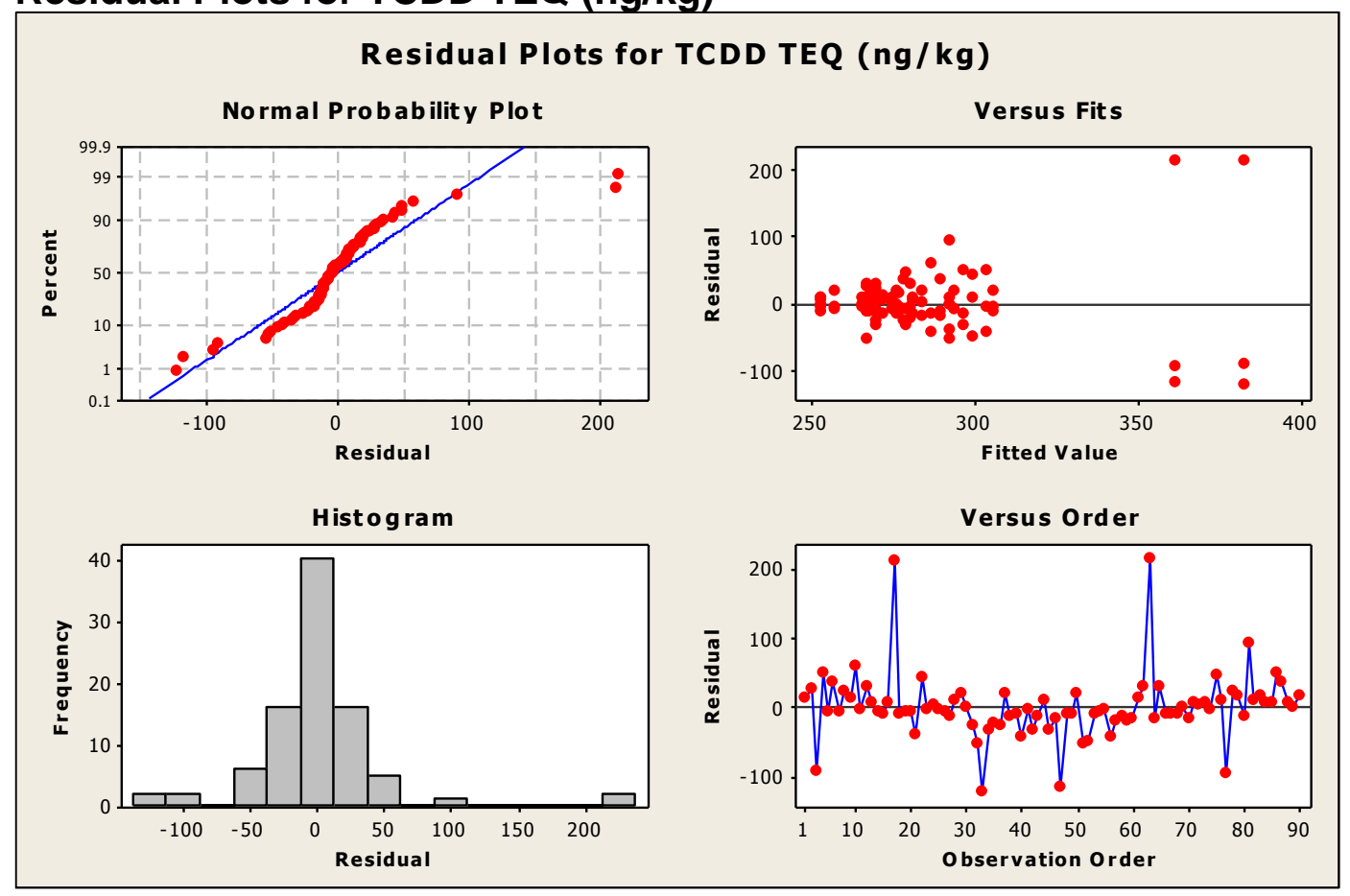

\section{Log(TCDD TEQ)}

General Linear Model: log(TCDDTEQ) versus Treatment, Replicate

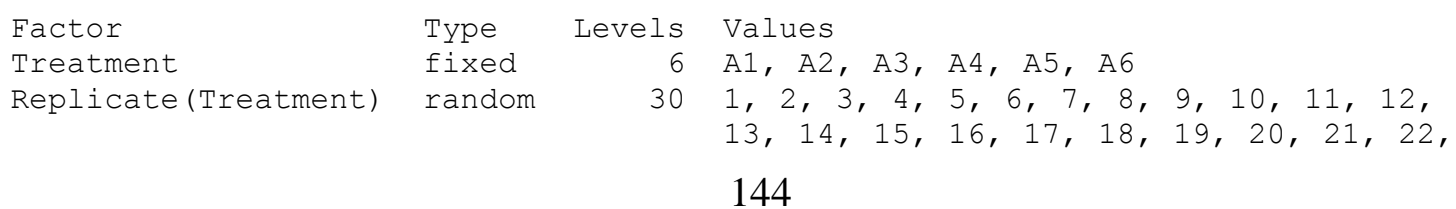


Analysis of Variance for log(TCDDTEQ), using Adjusted SS for Tests

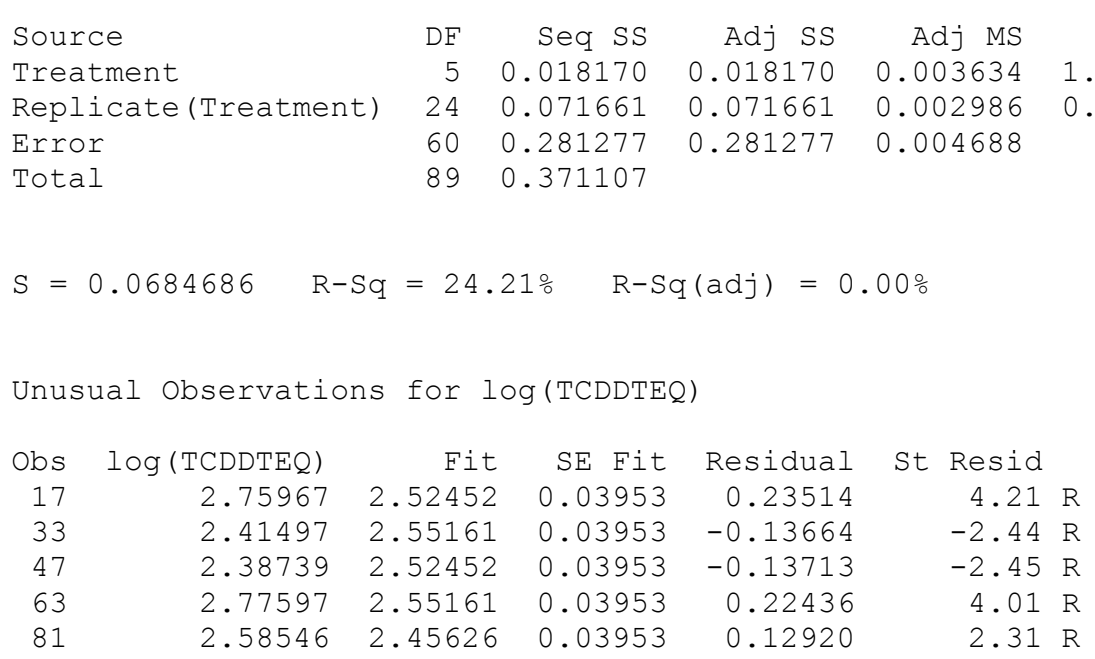

$\mathrm{R}$ denotes an observation with a large standardized residual.

Residual Plots for log(TCDDTEQ)

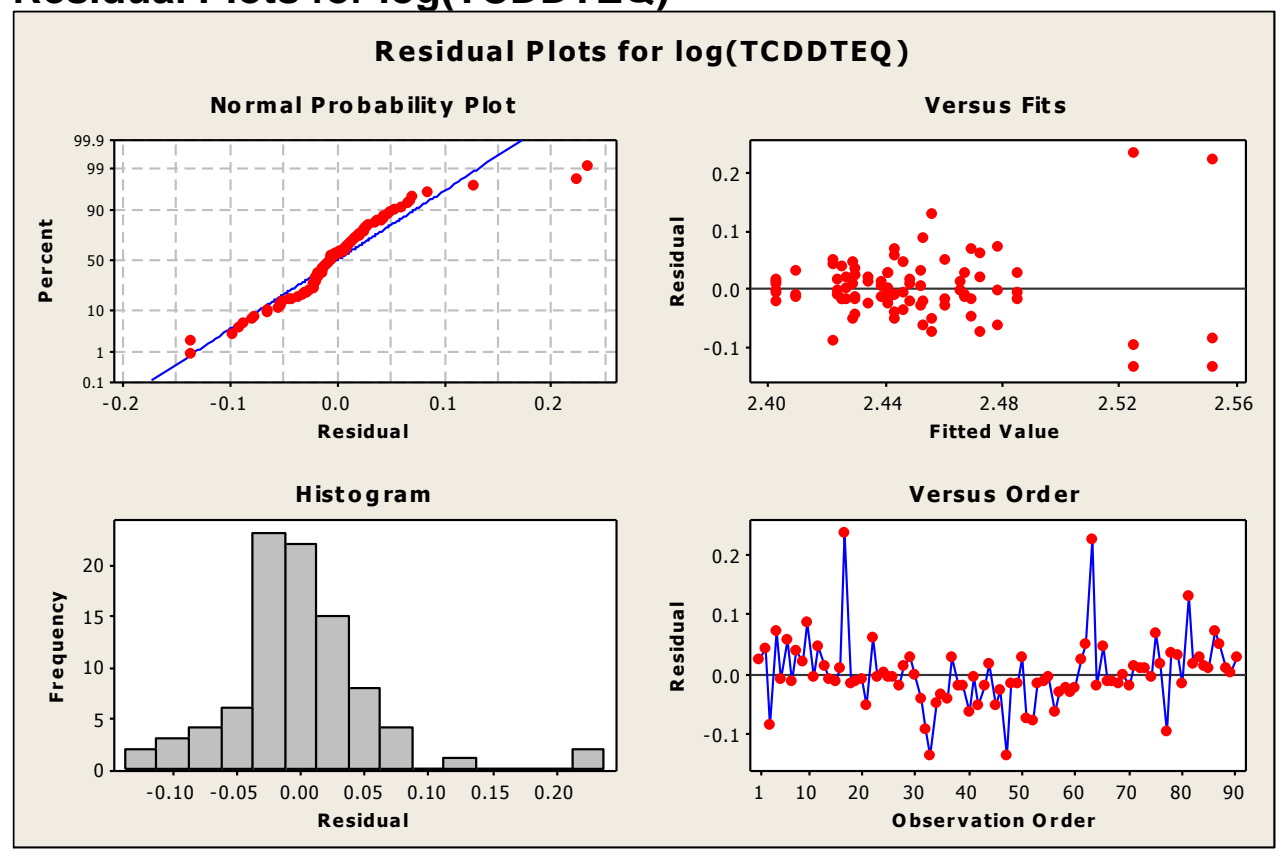


Appendix G: Statistics: Effect of Gamma Irradiation on Changes in Soil A COIs

\section{General Linear Model: PAHs (ug/kg) versus Treatment, Time, Replicate}

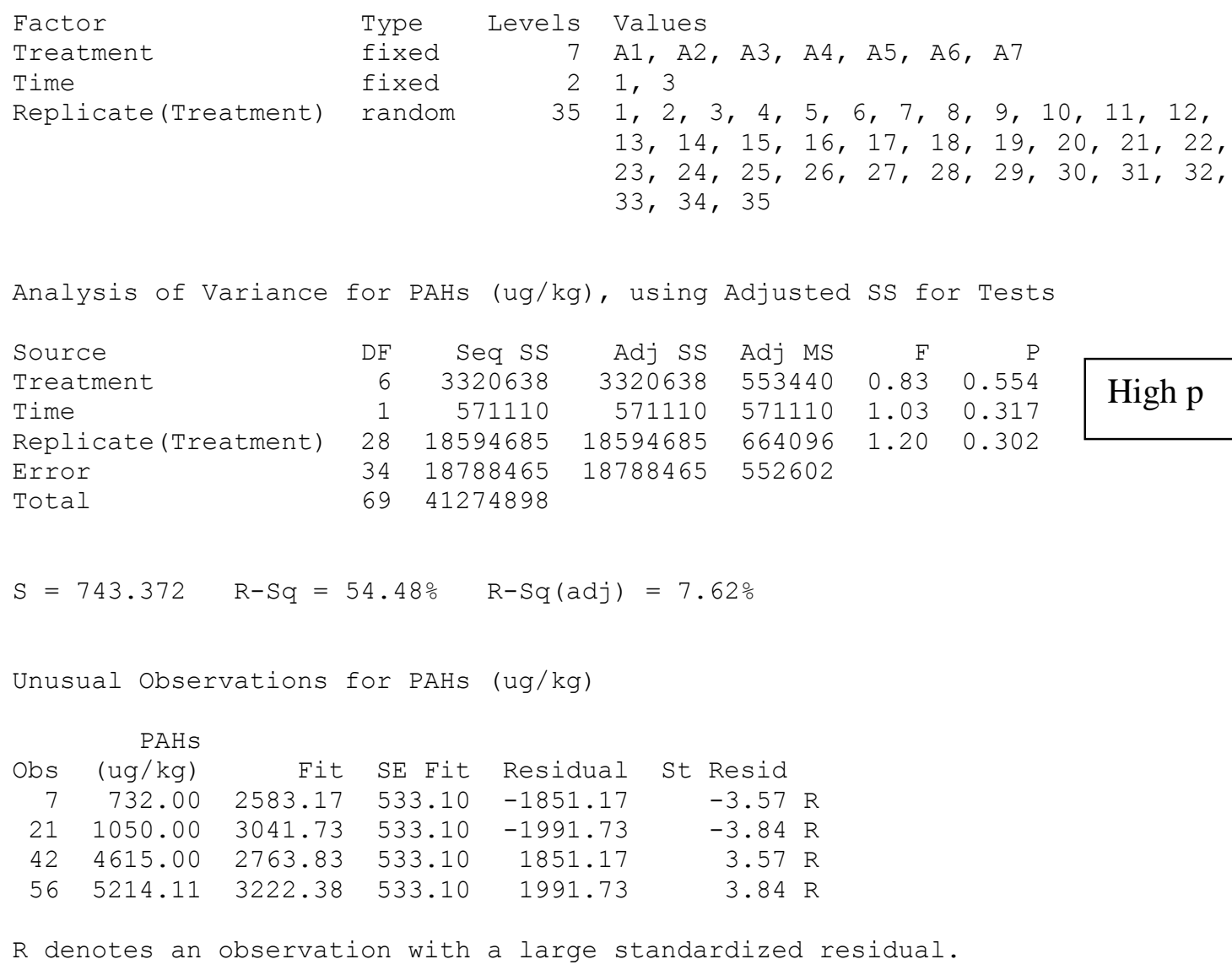

Residual Plots for PAHs (ug/kg) 


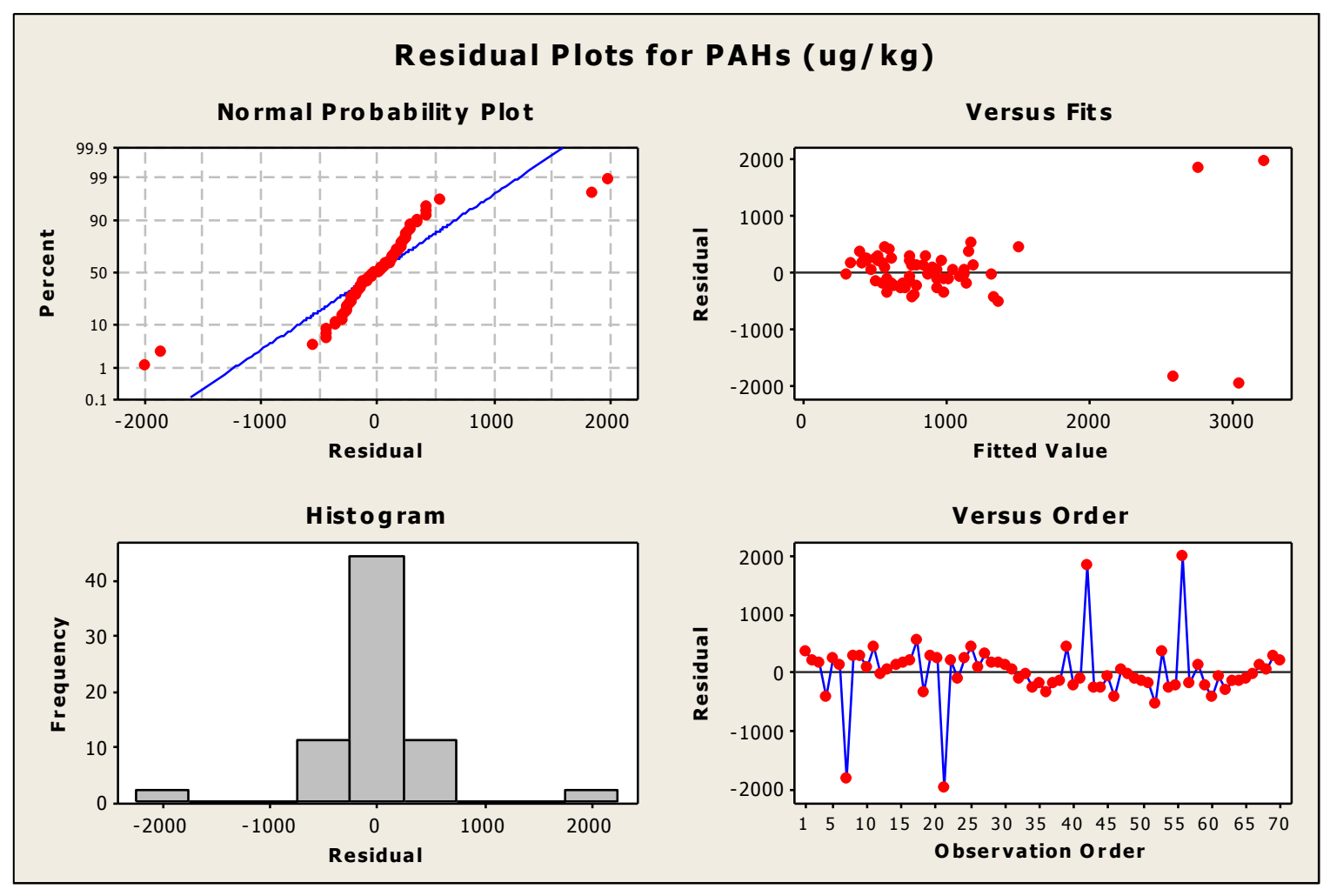

\section{General Linear Model: $\log (\mathrm{PAH})$ versus Treatment, Time, Replicate}

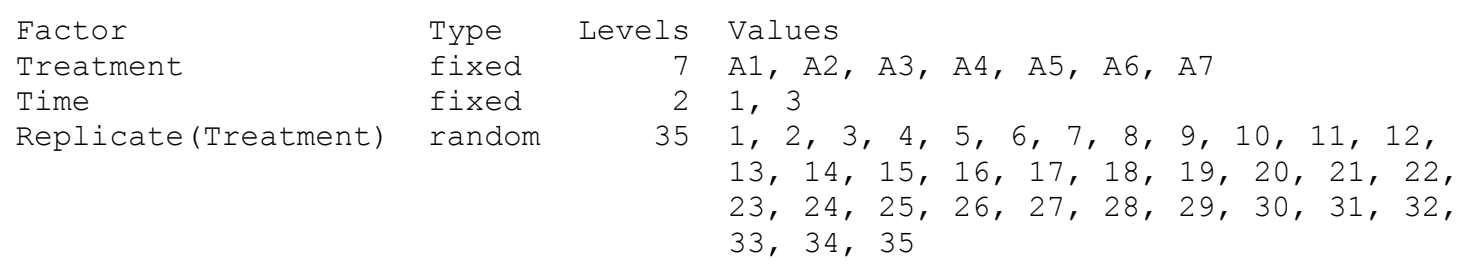

Analysis of Variance for log(PAH), using Adjusted SS for Tests

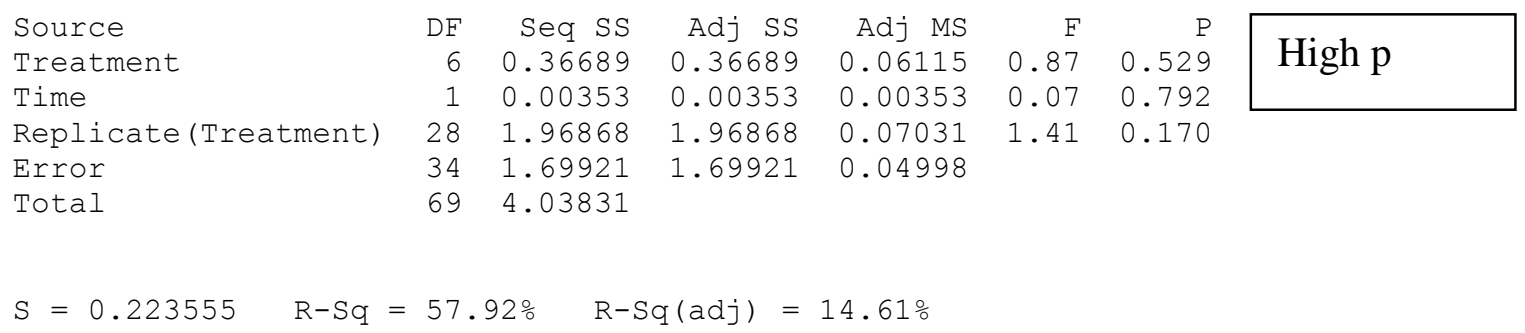

Unusual Observations for $\log (\mathrm{PAH})$

$\begin{array}{rrrrrrr}\text { Obs } & \text { log(PAH) } & \text { Fit } & \text { SE Fit } & \text { Residual } & \text { St Resid } \\ 7 & 2.86451 & 3.27144 & 0.16032 & -0.40693 & -2.61 \mathrm{R} \\ 21 & 3.02119 & 3.37629 & 0.16032 & -0.35510 & -2.28 \mathrm{R} \\ 42 & 3.66417 & 3.25724 & 0.16032 & 0.40693 & 2.61 \mathrm{R} \\ 56 & 3.71718 & 3.36208 & 0.16032 & 0.35510 & 2.28 \mathrm{R}\end{array}$




\section{Residual Plots for log(PAH)}

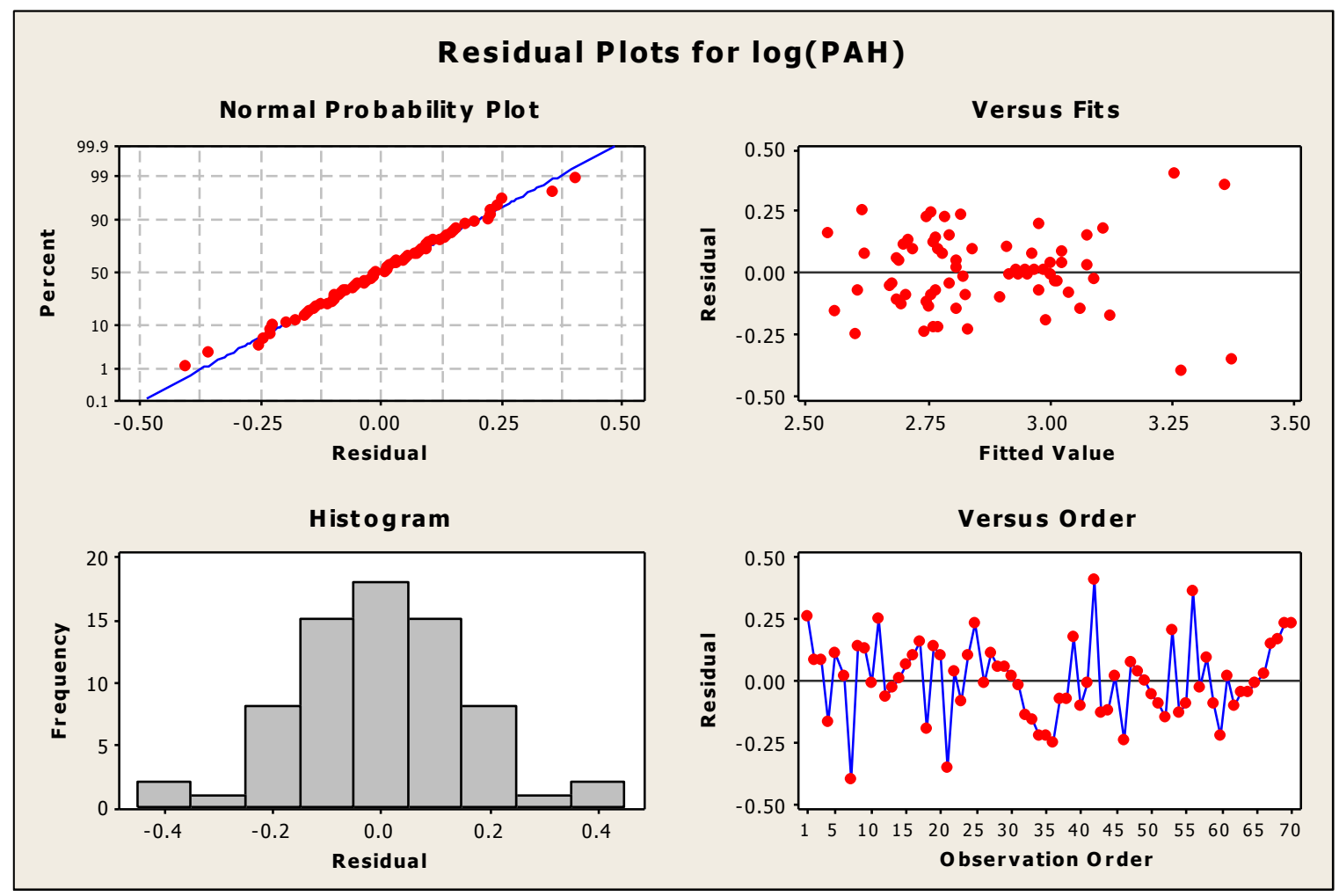

\section{General Linear Model: Dioxins (ng/kg) versus Treatment, Time, Replicate}

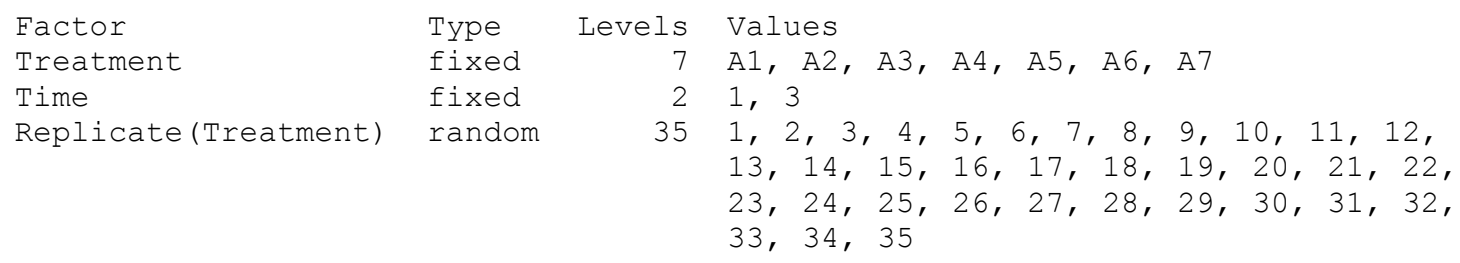

Analysis of Variance for Dioxins (ng/kg), using Adjusted SS for Tests

$\begin{array}{lrrrrrrr}\text { Source } & \text { DF } & \text { Seq SS } & \text { Adj SS } & \text { Adj MS } & \text { F } & \text { P } & \text { High p } \\ \text { Treatment } & 6 & 2926809955 & 2926809955 & 487801659 & 0.86 & 0.537 & \text { High } \\ \text { Time } & 1 & 25059269 & 25059269 & 25059269 & 0.04 & 0.839 & \\ \text { Replicate(Treatment) } & 28 & 15898895857 & 15898895857 & 567817709 & 0.95 & 0.553 \\ \text { Error } & 34 & 20342899904 & 20342899904 & 598320585 & & \\ \text { Total } & 69 & 39193664986 & & & \\ \text { S } & \\ & \end{array}$


Unusual Observations for Dioxins (ng/kg)

\begin{tabular}{|c|c|c|c|c|c|c|}
\hline $\mathrm{b} b \mathrm{~s}$ & $\begin{array}{c}\text { Dioxins } \\
(\mathrm{ng} / \mathrm{kg})\end{array}$ & Fit & SE Fit & Residual & st & Resid \\
\hline 3 & 110514 & 170567 & 17542 & -60053 & & $-3.52 R$ \\
\hline 17 & 206618 & 142553 & 17542 & 64065 & & $3.76 \mathrm{R}$ \\
\hline 38 & 22942 & 169370 & 17542 & 60053 & & $3.52 \mathrm{R}$ \\
\hline 52 & 7729 & 141357 & 17542 & -64065 & & $-3.76 R$ \\
\hline
\end{tabular}

$\mathrm{R}$ denotes an observation with a large standardized residual.

\section{Residual Plots for Dioxins (ng/kg)}

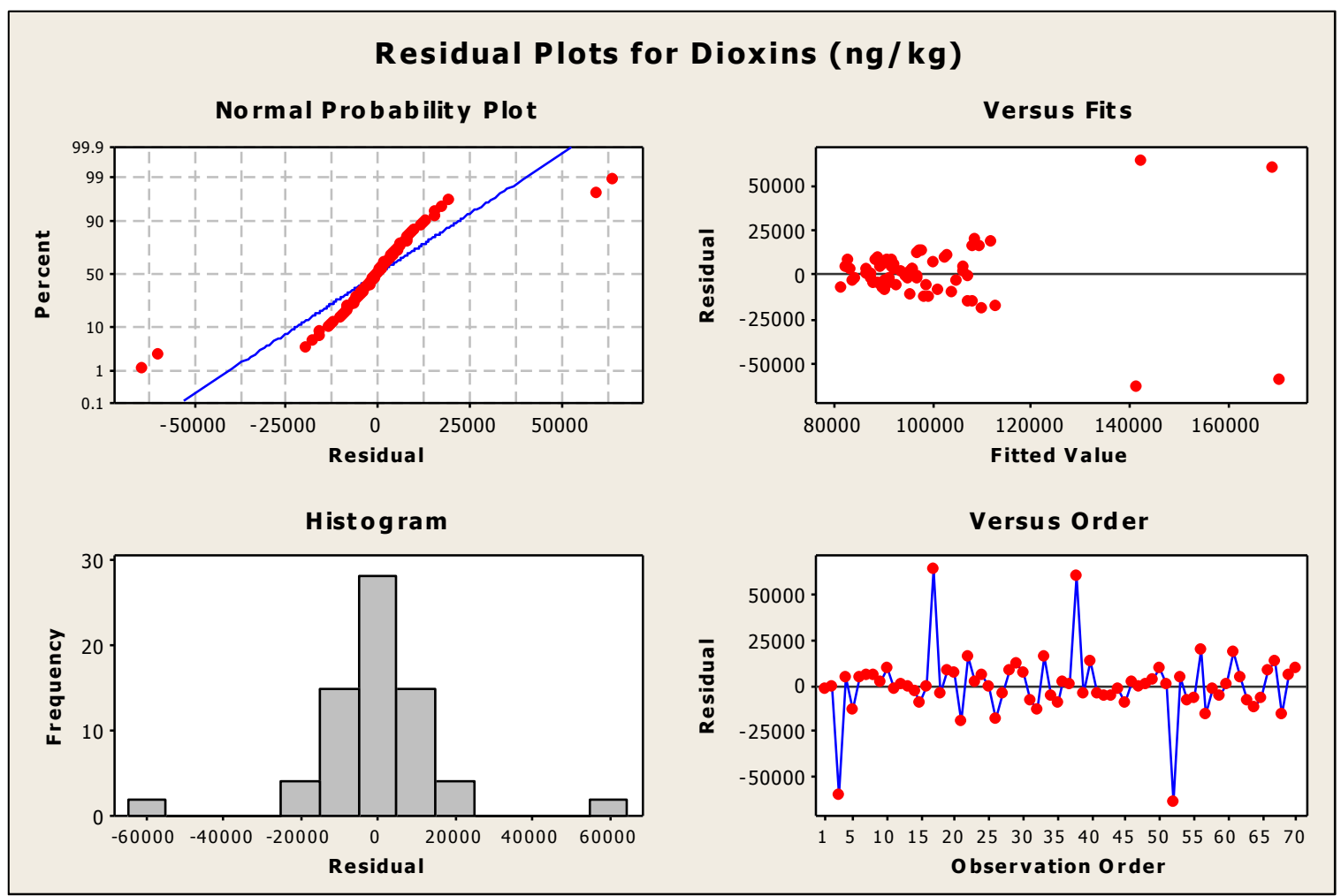

\section{General Linear Model: log(Dioxins) versus Treatment, Time, Replicate}

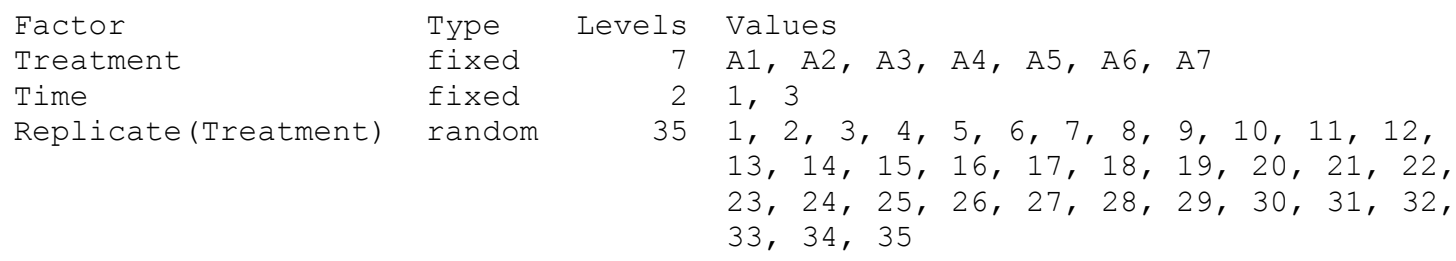

Analysis of Variance for log(Dioxins), using Adjusted SS for Tests

Source

Treatment $\begin{array}{rrrr}\text { DF } & \text { Seq SS } & \text { Adj SS } \\ 6 & 0.034056 & 0.034056\end{array}$

149 $\begin{array}{rrr}\text { Adj MS } & F & P \\ 0.005676 & 0.92 & 0.494\end{array}$

High $\mathrm{p}$ 


$\begin{array}{lrrrrrr}\text { Time } & 1 & 0.001079 & 0.001079 & 0.001079 & 0.16 & 0.694 \\ \text { Replicate(Treatment) } & 28 & 0.172286 & 0.172286 & 0.006153 & 0.90 & 0.613 \\ \text { Error } & 34 & 0.233299 & 0.233299 & 0.006862 & & \\ \text { Total } & 69 & 0.440719 & & & \\ & & & & & \\ \mathrm{~S}=0.0828355 \quad \mathrm{R}-\mathrm{Sq}=47.06 \% & \mathrm{R}-\mathrm{Sq}(\mathrm{adj})=0.00 \%\end{array}$

Unusual Observations for log(Dioxins)

$\begin{array}{rrrrrr}\text { Obs } & \text { log(Dioxins) } & \text { Fit } & \text { SE Fit } & \text { Residual } & \text { St Resid } \\ 3 & 5.04342 & 5.20595 & 0.05940 & -0.16254 & -2.82 \mathrm{R} \\ 17 & 5.31517 & 5.10558 & 0.05940 & 0.20959 & 3.63 \mathrm{R} \\ 38 & 5.36064 & 5.19810 & 0.05940 & 0.16254 & 2.82 \mathrm{R} \\ 52 & 4.88813 & 5.09773 & 0.05940 & -0.20959 & -3.63 \mathrm{R}\end{array}$

$\mathrm{R}$ denotes an observation with a large standardized residual.

\section{Residual Plots for log(Dioxins)}

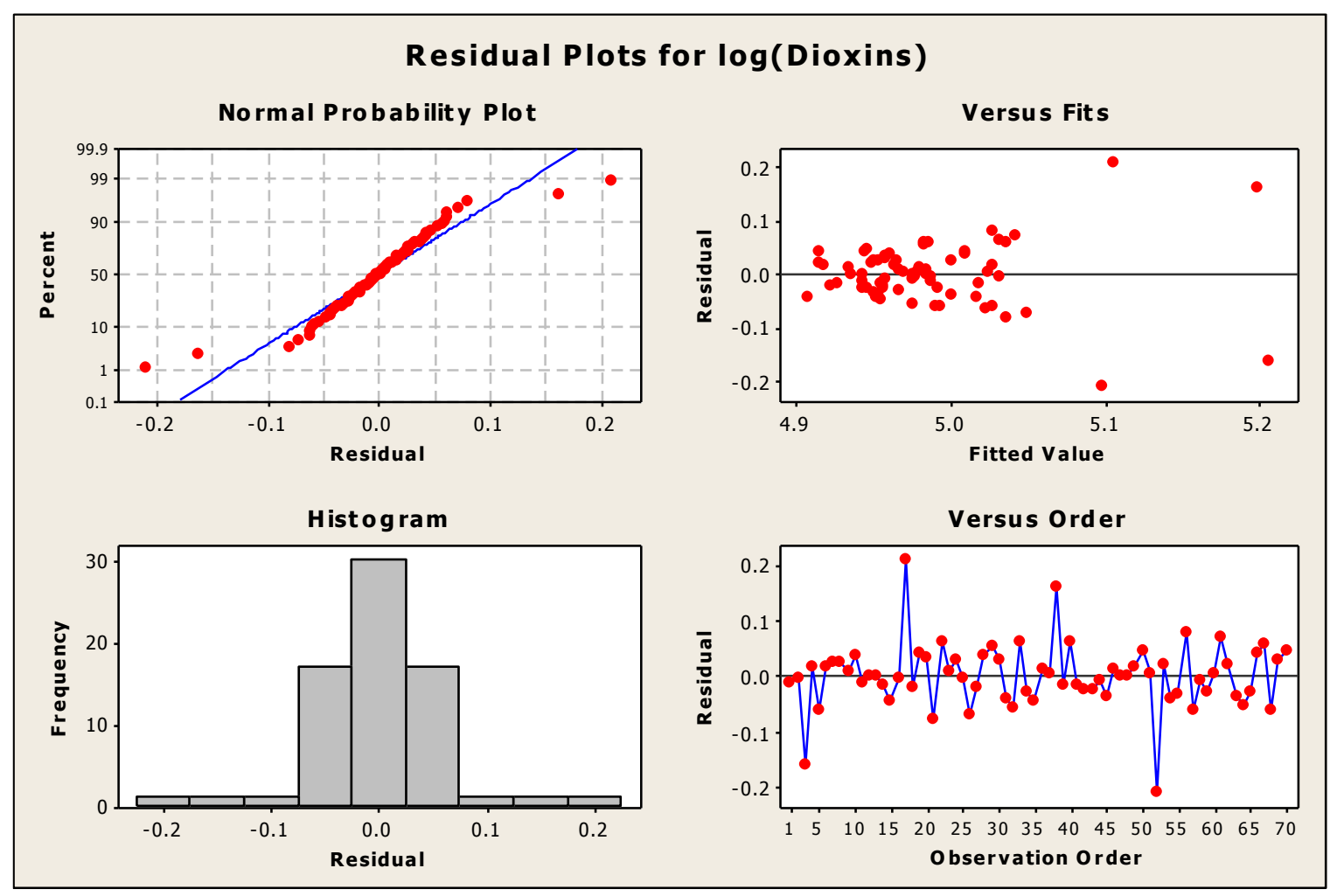

\section{General Linear Model: sqrt(Dioxins) versus Treatment, Time, Replicate}

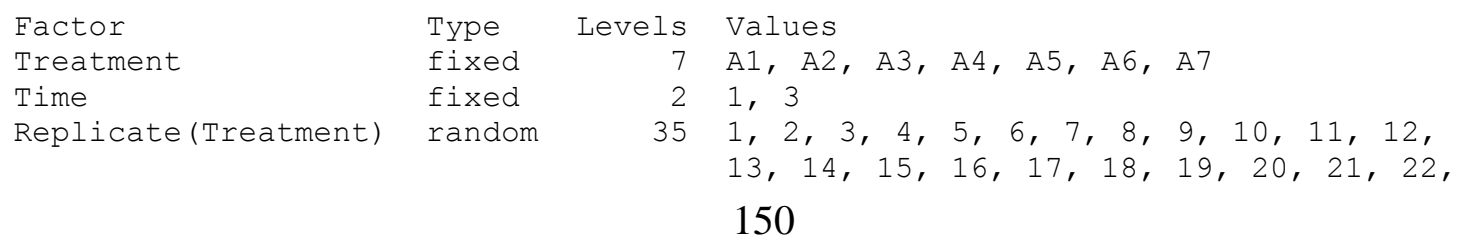


$23,24,25,26,27,28,29,30,31,32$,

$33,34,35$

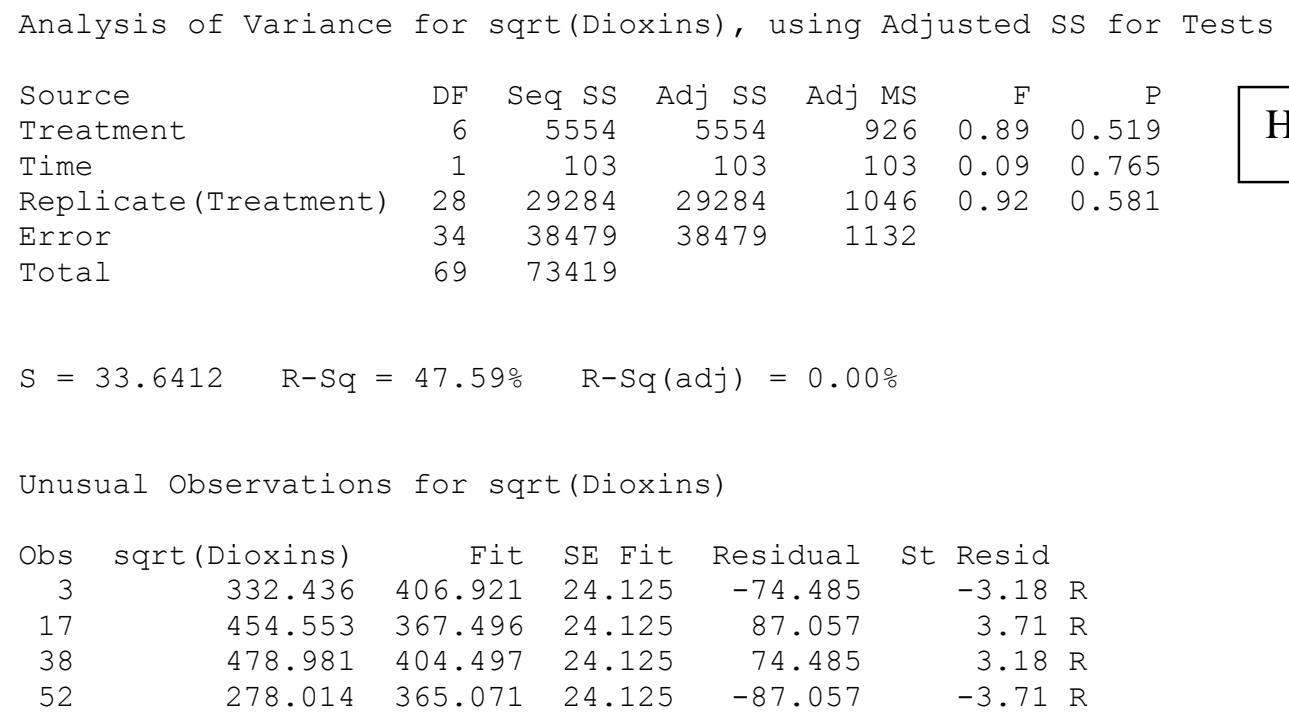

$\mathrm{R}$ denotes an observation with a large standardized residual.

\section{Residual Plots for sqrt(Dioxins)}

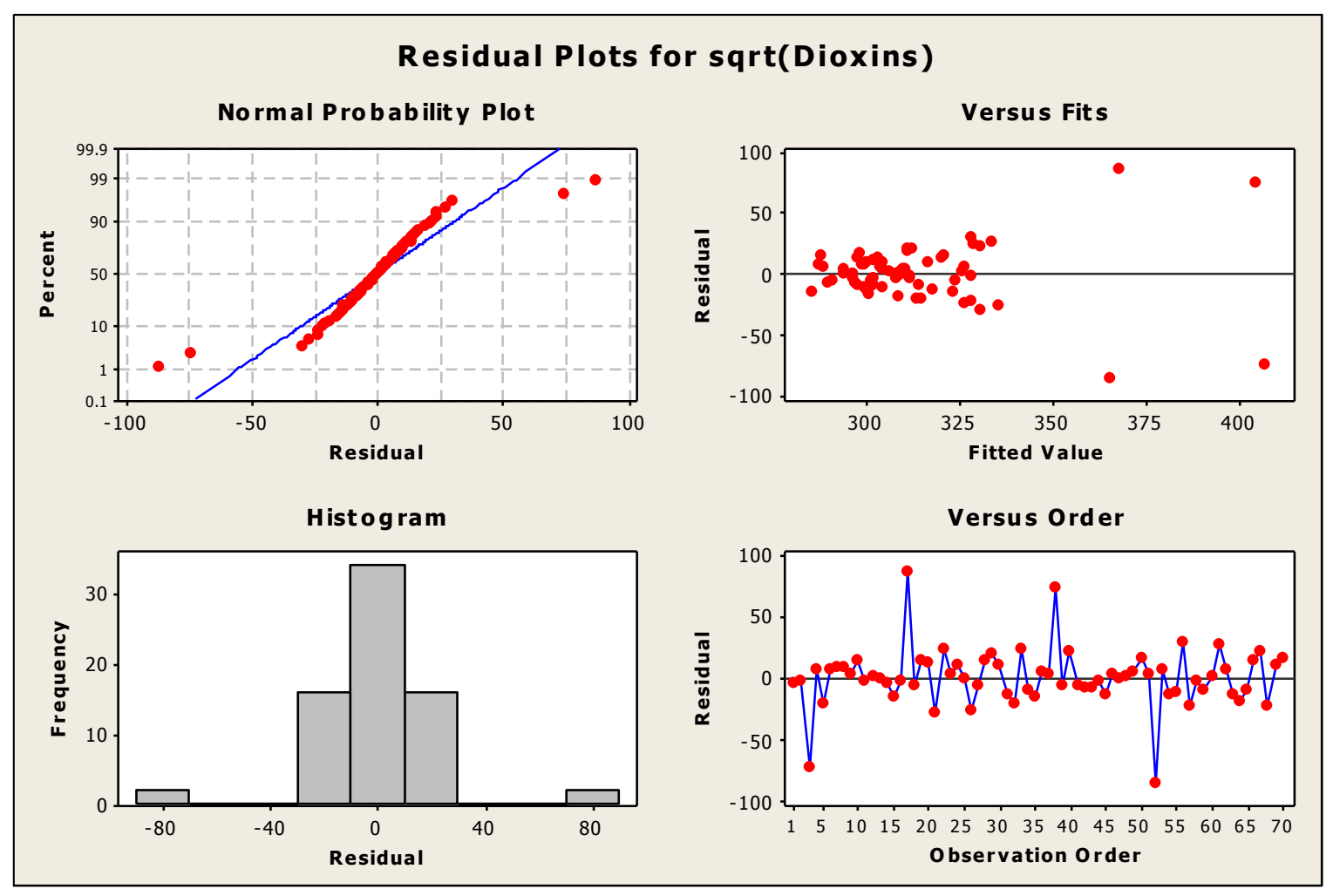




\section{General Linear Model: PCBs (ug/kg) versus Treatment, Time, Replicate}

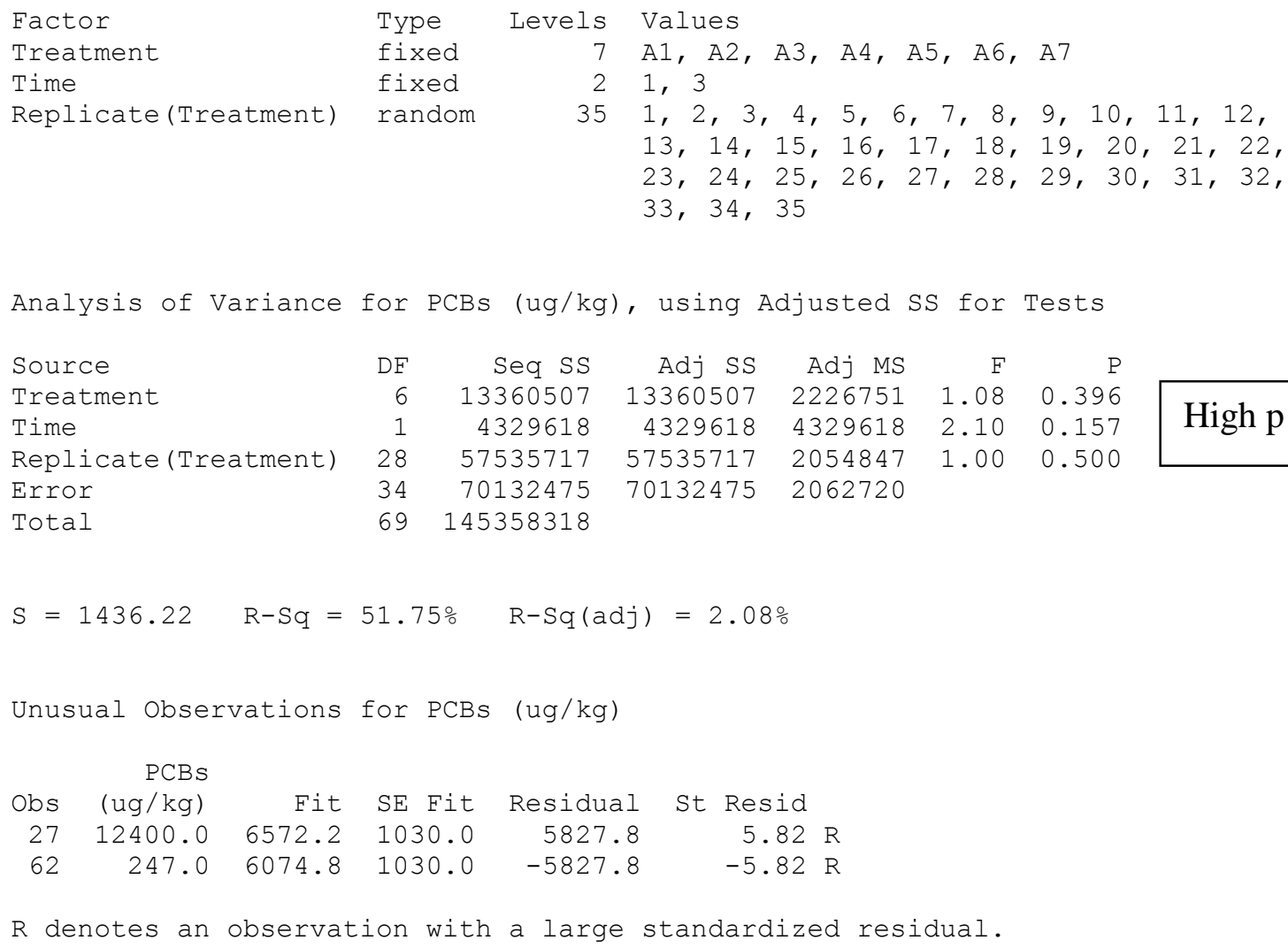

Residual Plots for PCBs (ug/kg) 


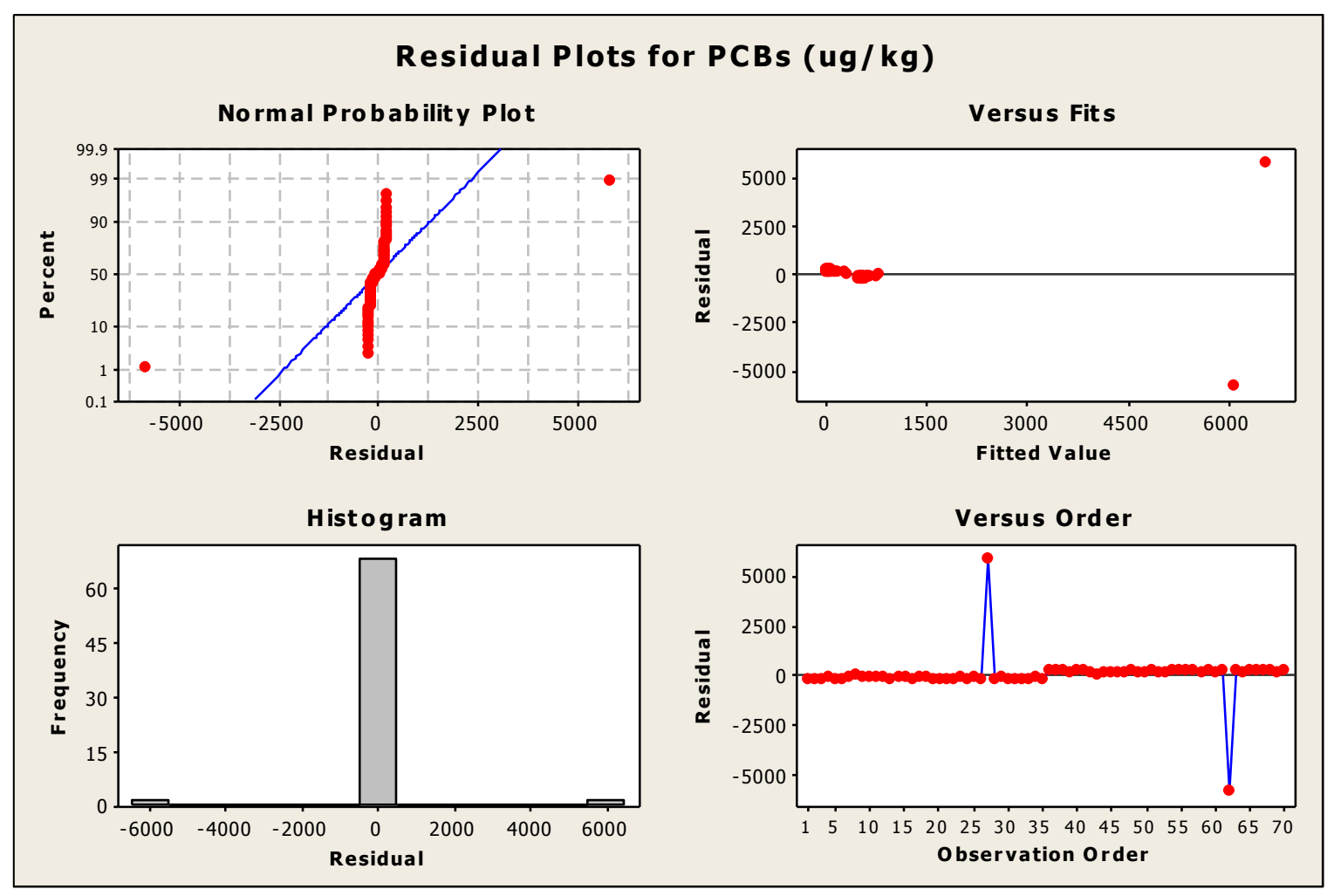

\section{General Linear Model: log(PCBs) versus Treatment, Time, Replicate}

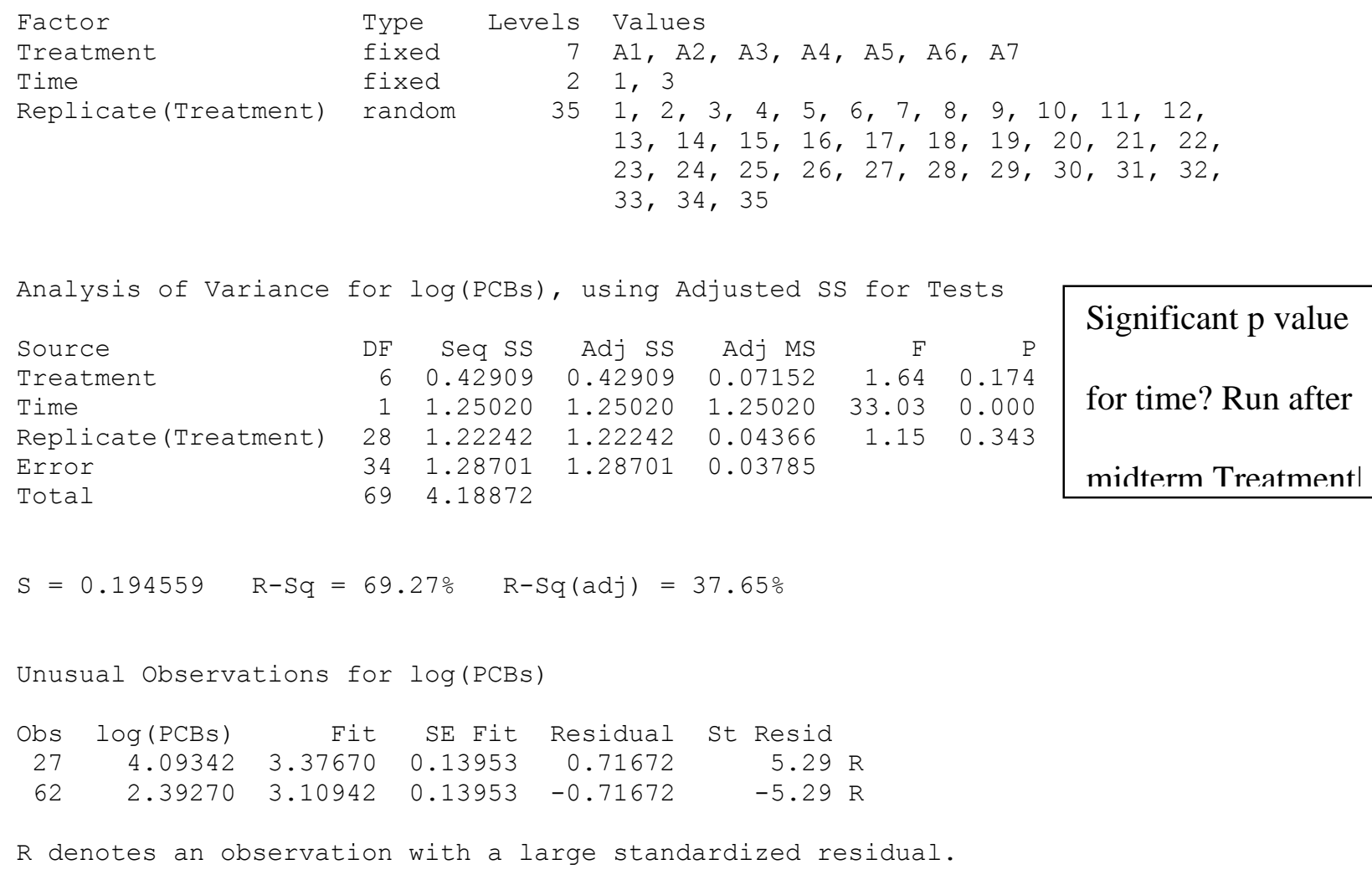

Significant $\mathrm{p}$ value

for time? Run after

midterm Treatmentl 


$$
\begin{array}{llllll}
62 & 15.716 & 60.023 & 7.929 & -44.307 & -5.75 \mathrm{R}
\end{array}
$$

$\mathrm{R}$ denotes an observation with a large standardized residual.

\section{Residual Plots for sqrt(PCBs)}

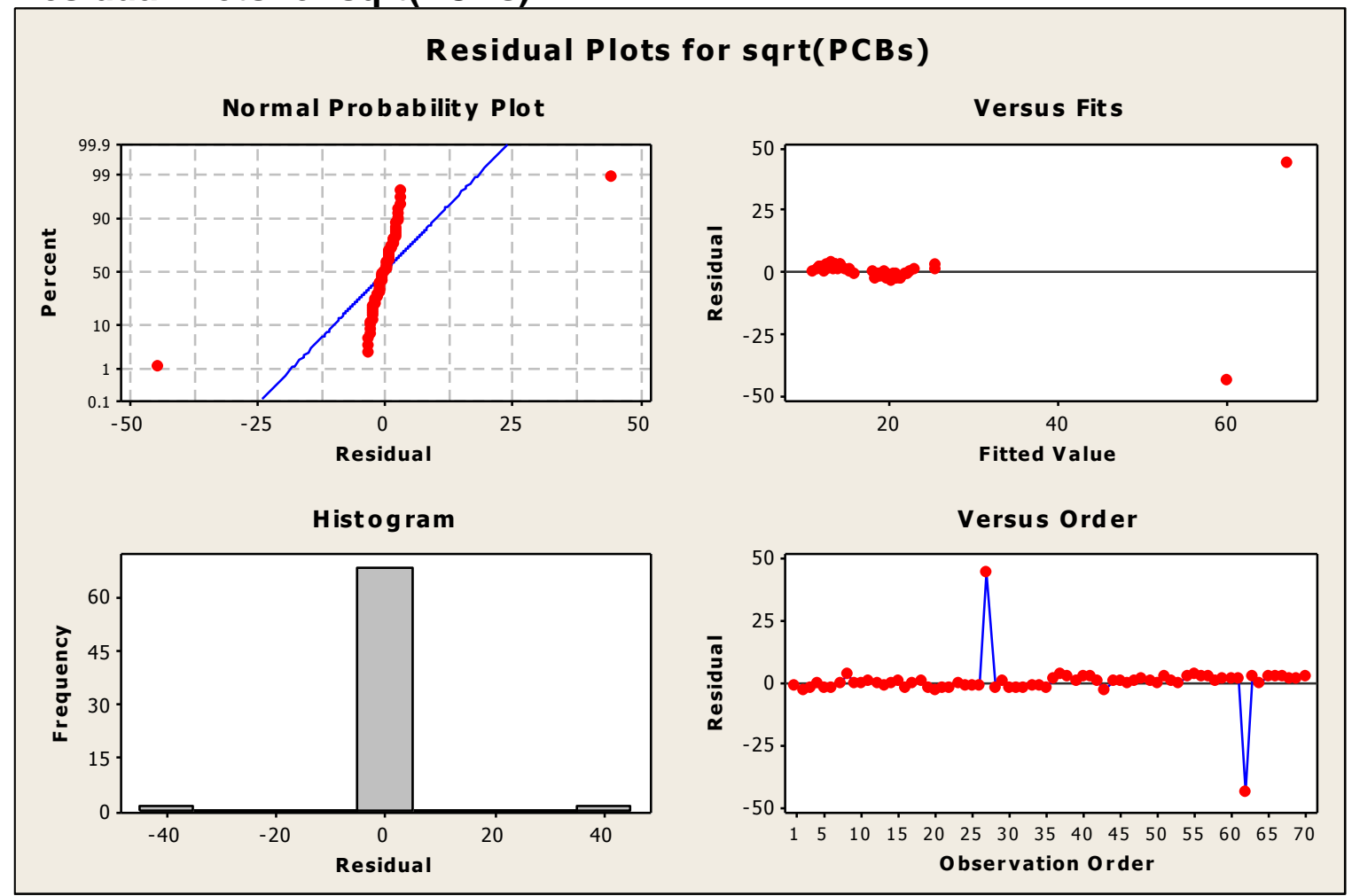

\section{General Linear Model: TCDD TEQ (ng/kg) versus Treatment, Time, Replicate}

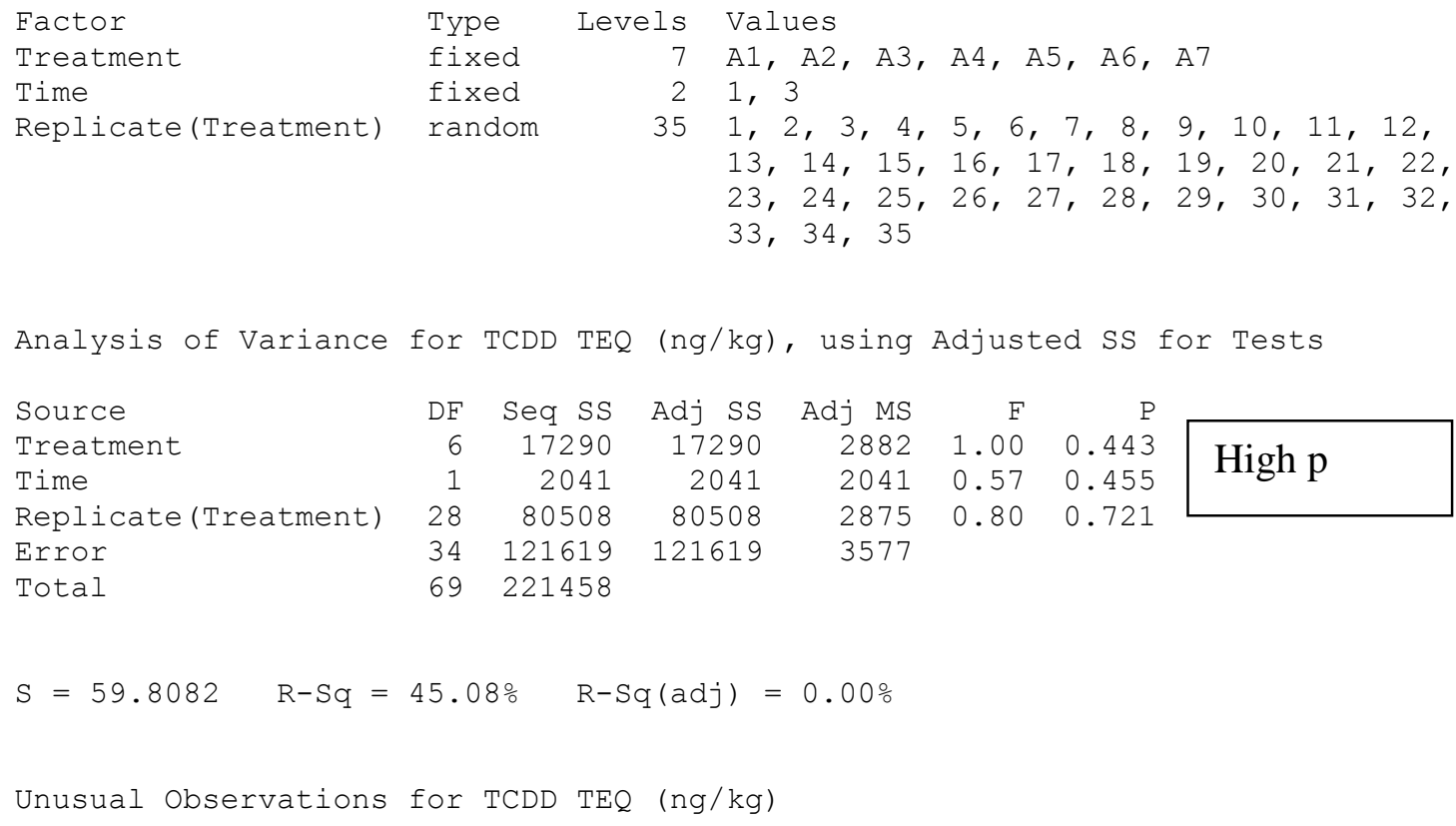




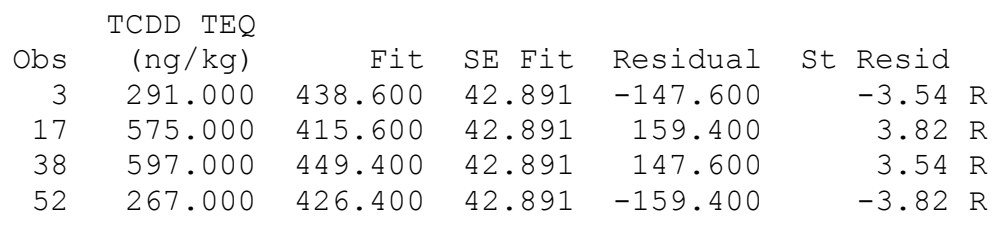

$\mathrm{R}$ denotes an observation with a large standardized residual.

\section{Residual Plots for TCDD TEQ (ng/kg)}

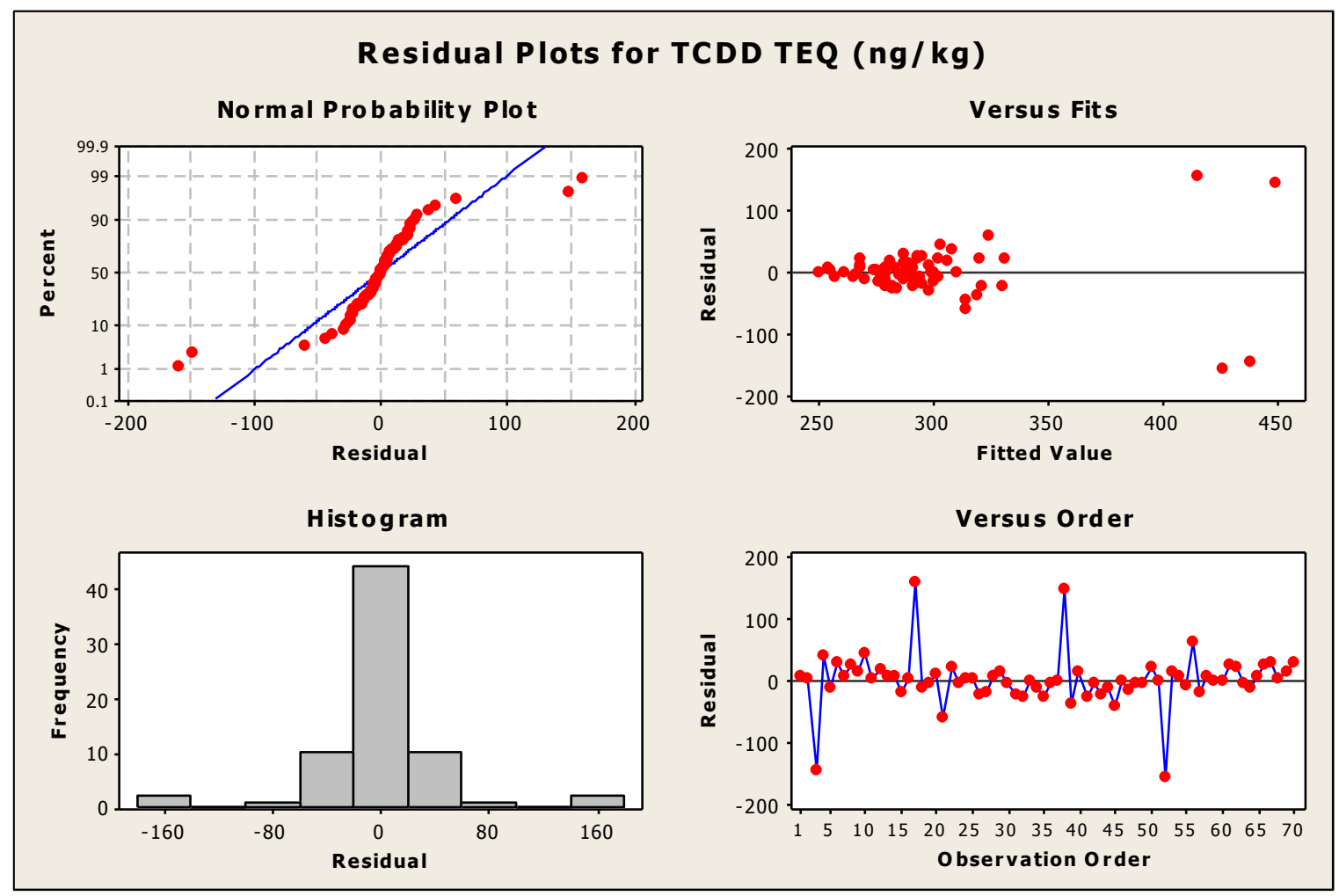

\section{General Linear Model: log(TCDDTEQ) versus Treatment, Time, Replicate}

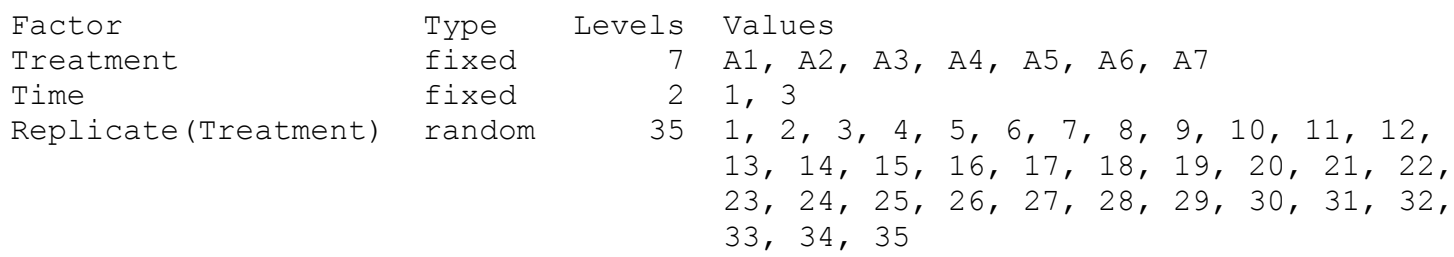

Analysis of Variance for log(TCDDTEQ), using Adjusted SS for Tests
Source
Treatment
$\begin{array}{rrr}\text { DF } & \text { Seq } & \text { SS } \\ 6 & 0.025881\end{array}$
Adj SS
0.004291
0.025881
Adj MS
0.004314
$F$
1.23
0.004291
0.004291
0.90
0.098145
0.098145
0.003505
0.74
0.321
0.348
Replicate (Treatment)
28

\section{6}




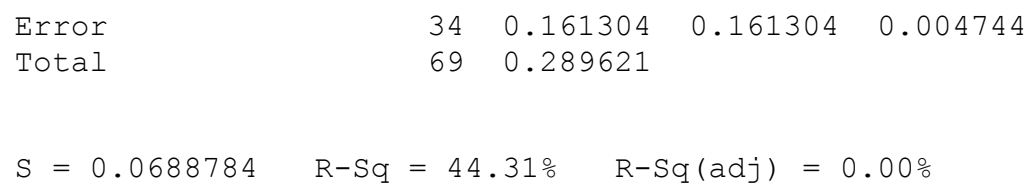

$\begin{array}{rrrrrr}\text { Obs } & \text { log(TCDDTEQ }) & \text { Fit } & \text { SE Fit } & \text { Residual } & \text { St Resid } \\ 3 & 2.46389 & 2.61210 & 0.04940 & -0.14821 & -3.09 \text { R } \\ 17 & 2.75967 & 2.58526 & 0.04940 & 0.17441 & 3.63 \mathrm{R} \\ 38 & 2.77597 & 2.62776 & 0.04940 & 0.14821 & 3.09 \mathrm{R} \\ 52 & 2.42651 & 2.60092 & 0.04940 & -0.17441 & -3.63 \mathrm{R}\end{array}$

$\mathrm{R}$ denotes an observation with a large standardized residual.

\section{Residual Plots for log(TCDDTEQ)}

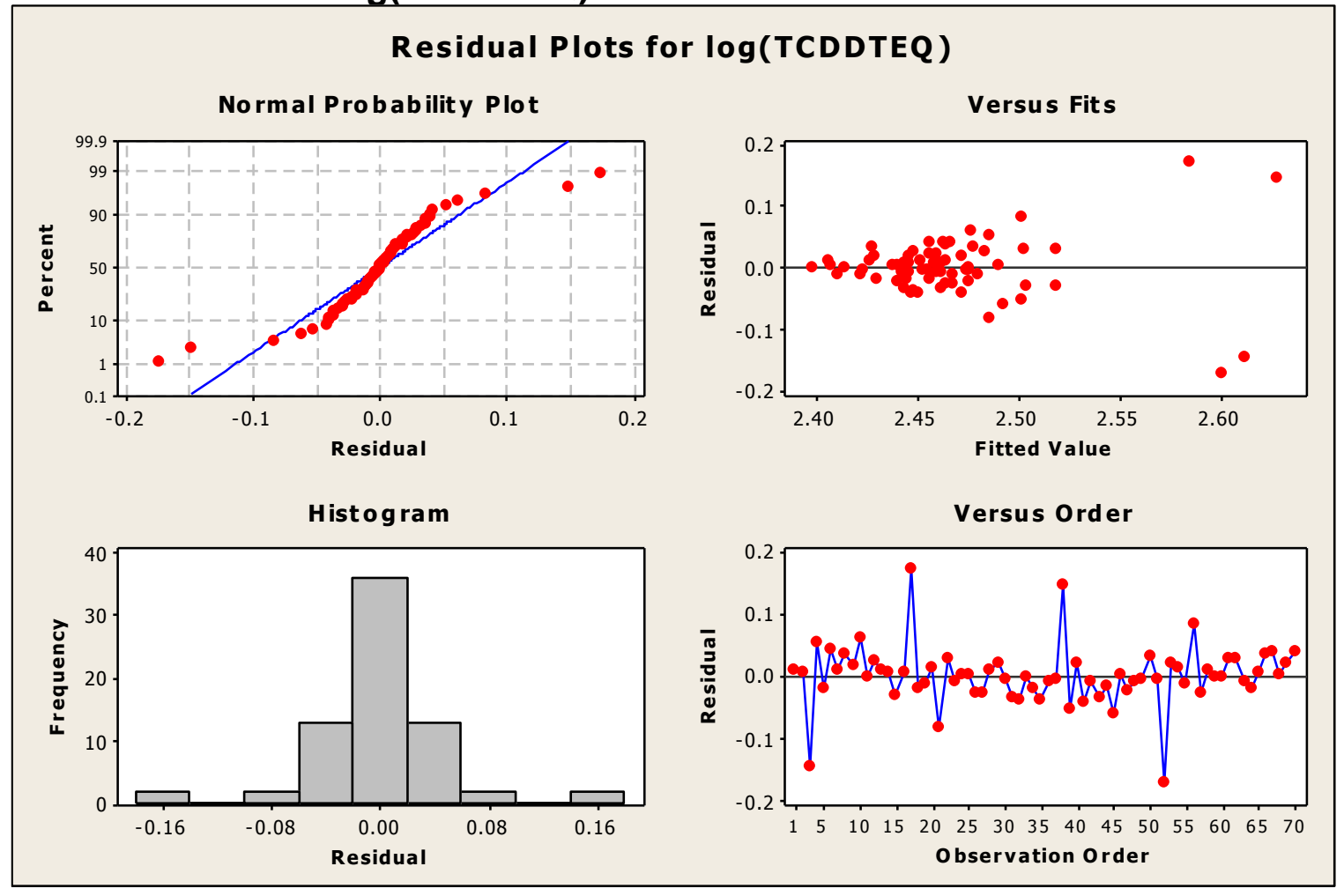


Appendix H: Statistics: Effect of Soil Type (A, B, or C) on COIs

General Linear Model: Dioxins (ng/kg) versus Treatment, Time, Replicate

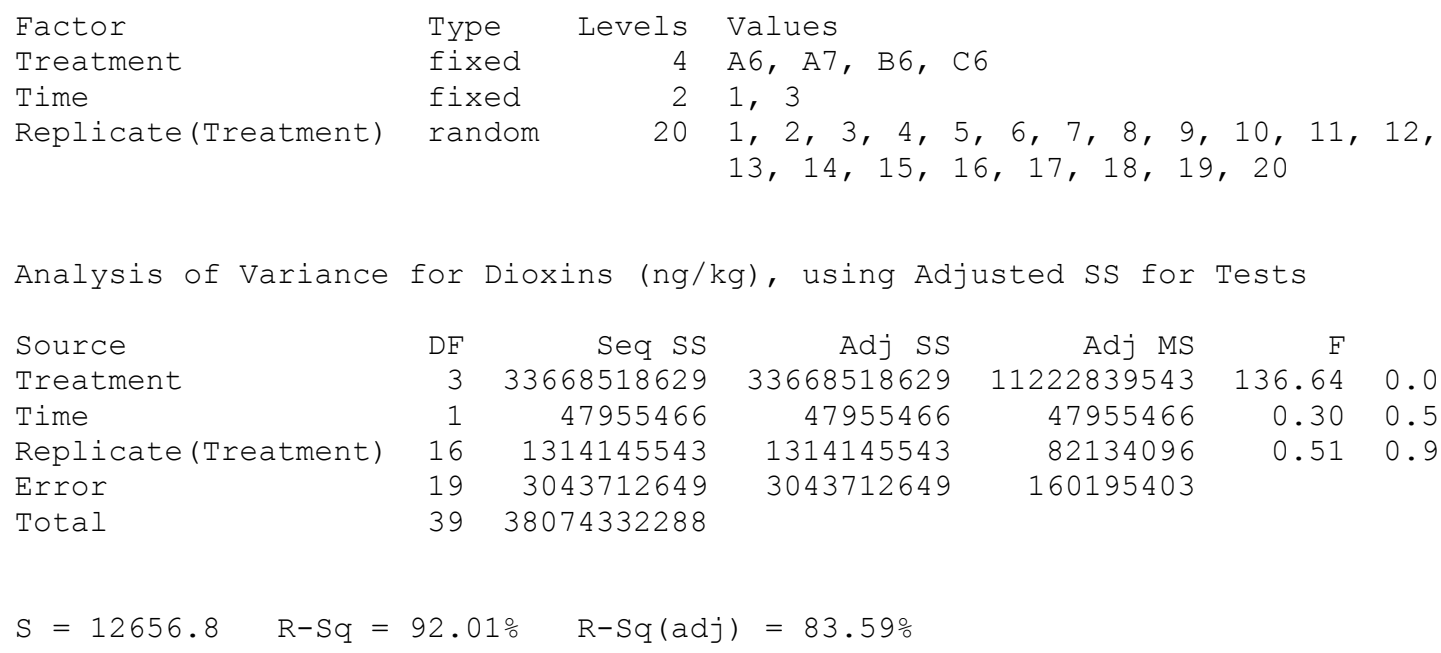

\section{Residual Plots for Dioxins (ng/kg)}

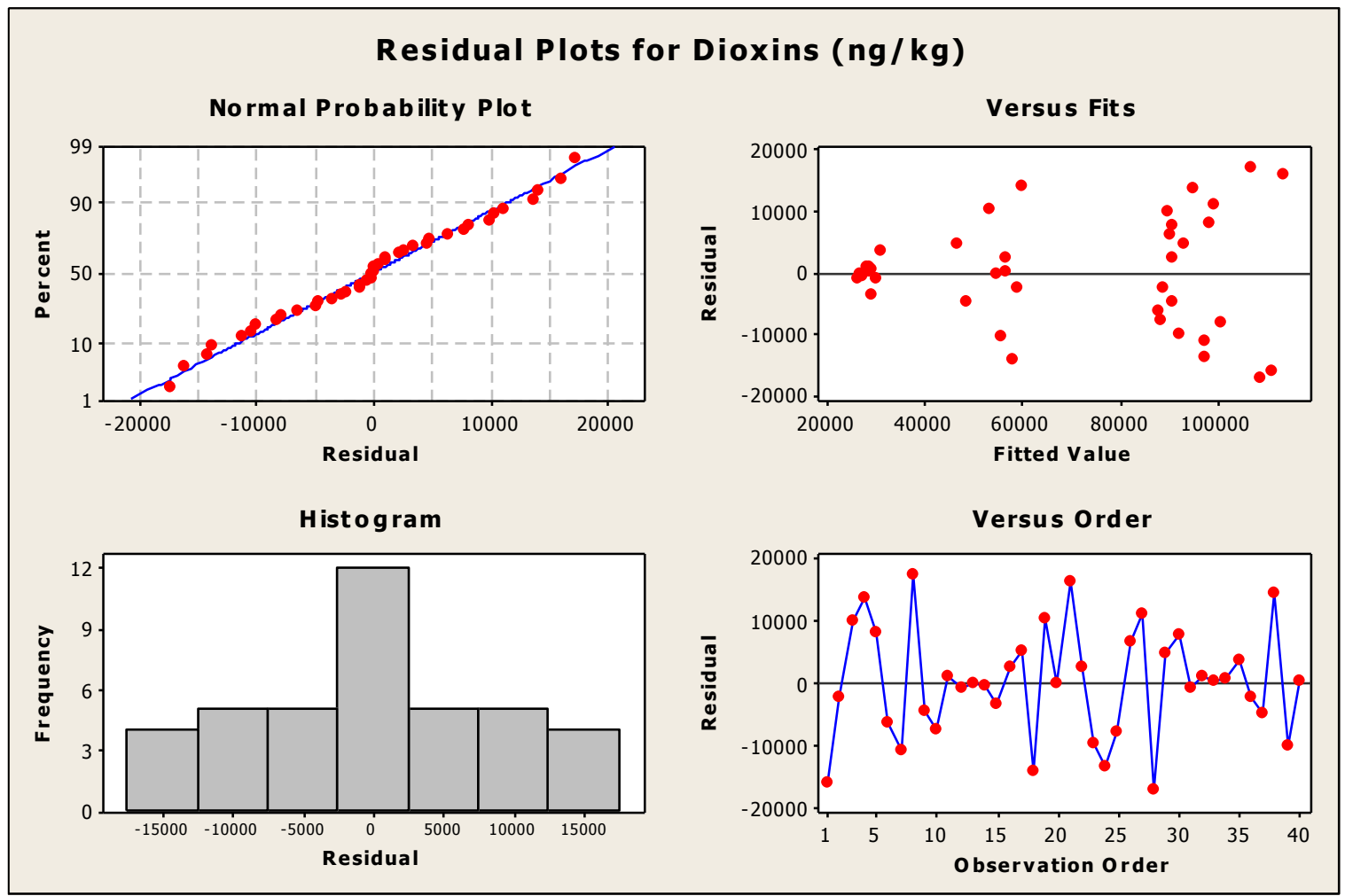

General Linear Model: log(Dioxins versus Treatment, Time, Replicate 


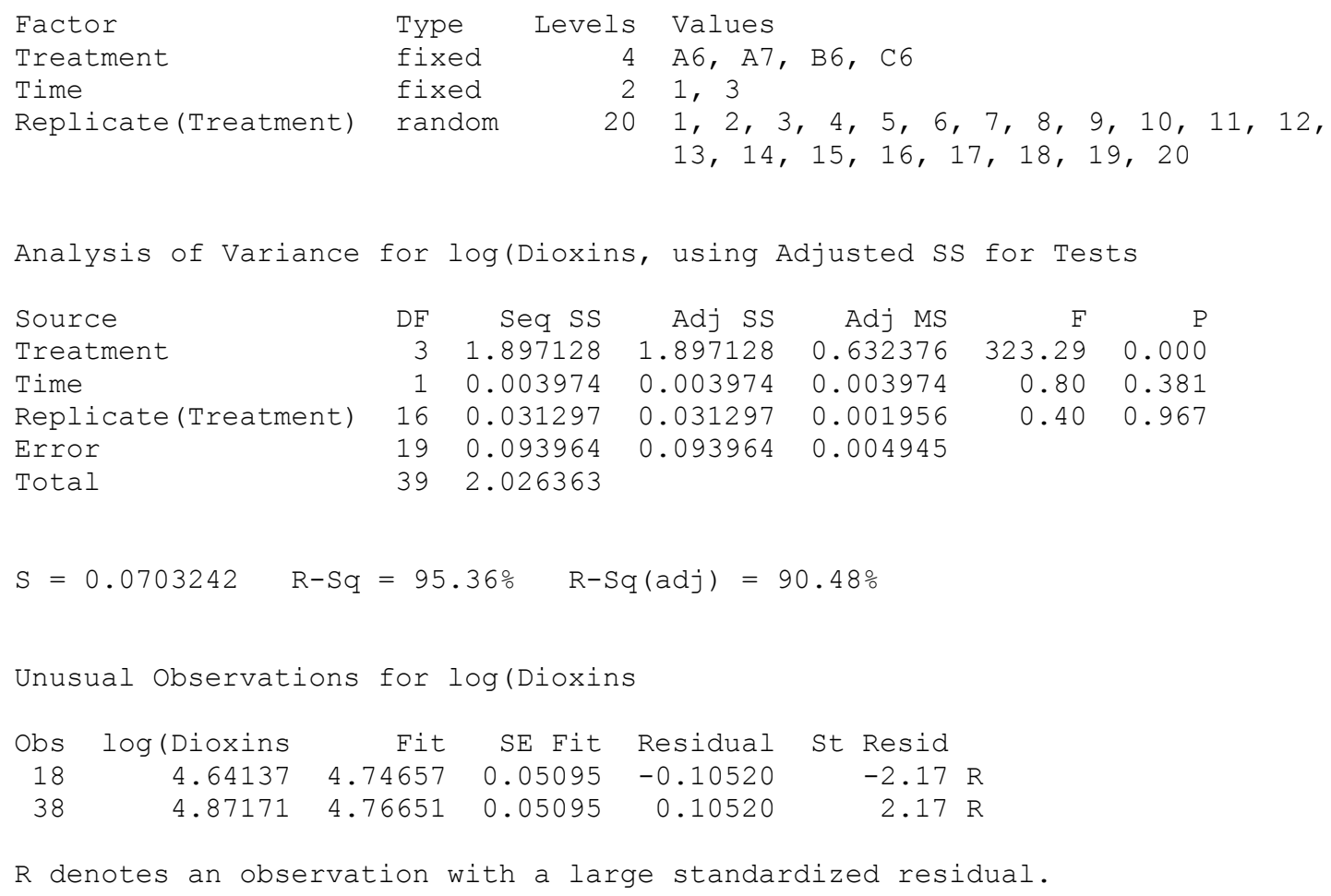

\section{Residual Plots for log(Dioxins}




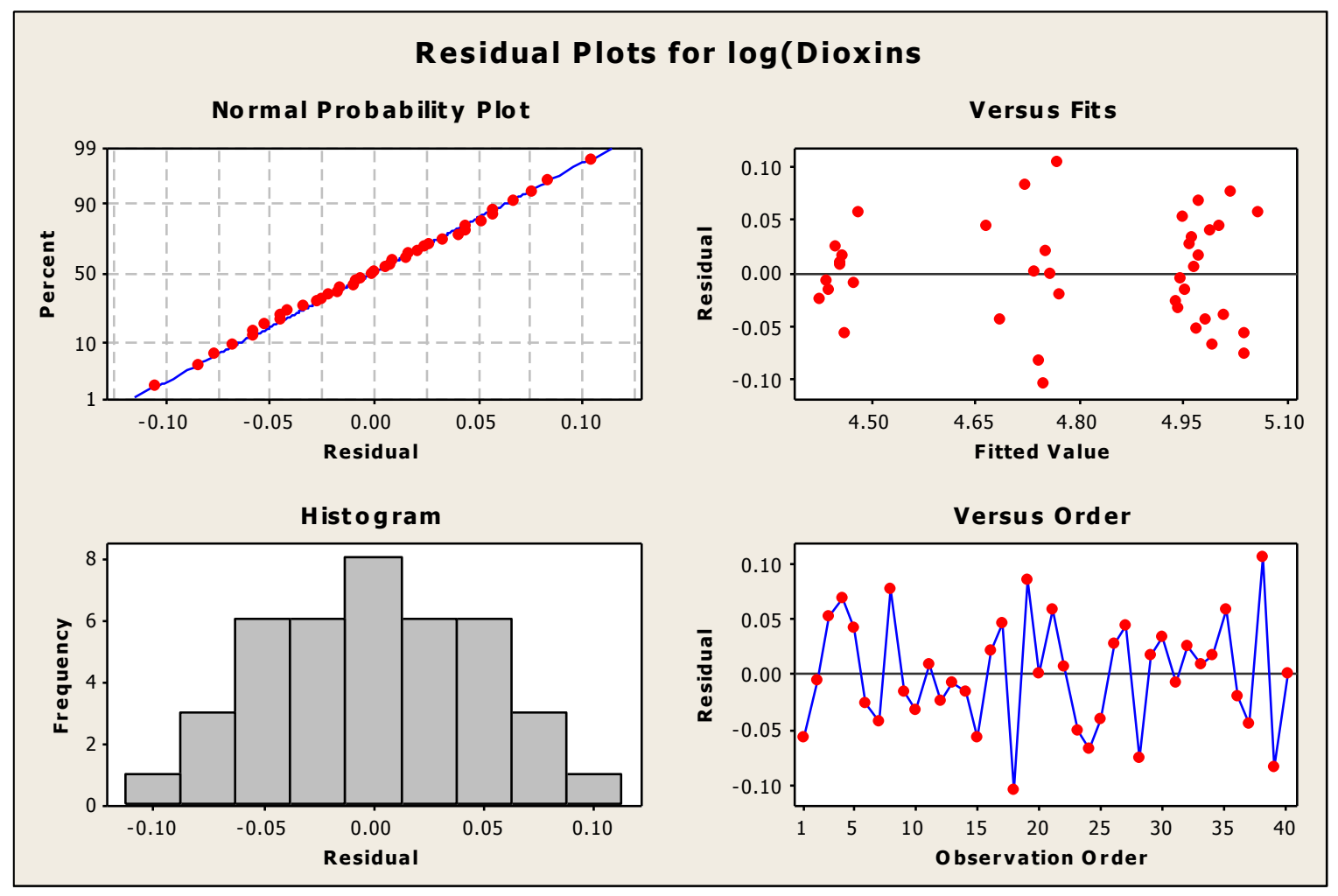

General Linear Model: PAHs (ug/kg) versus Treatment, Time, Replicate

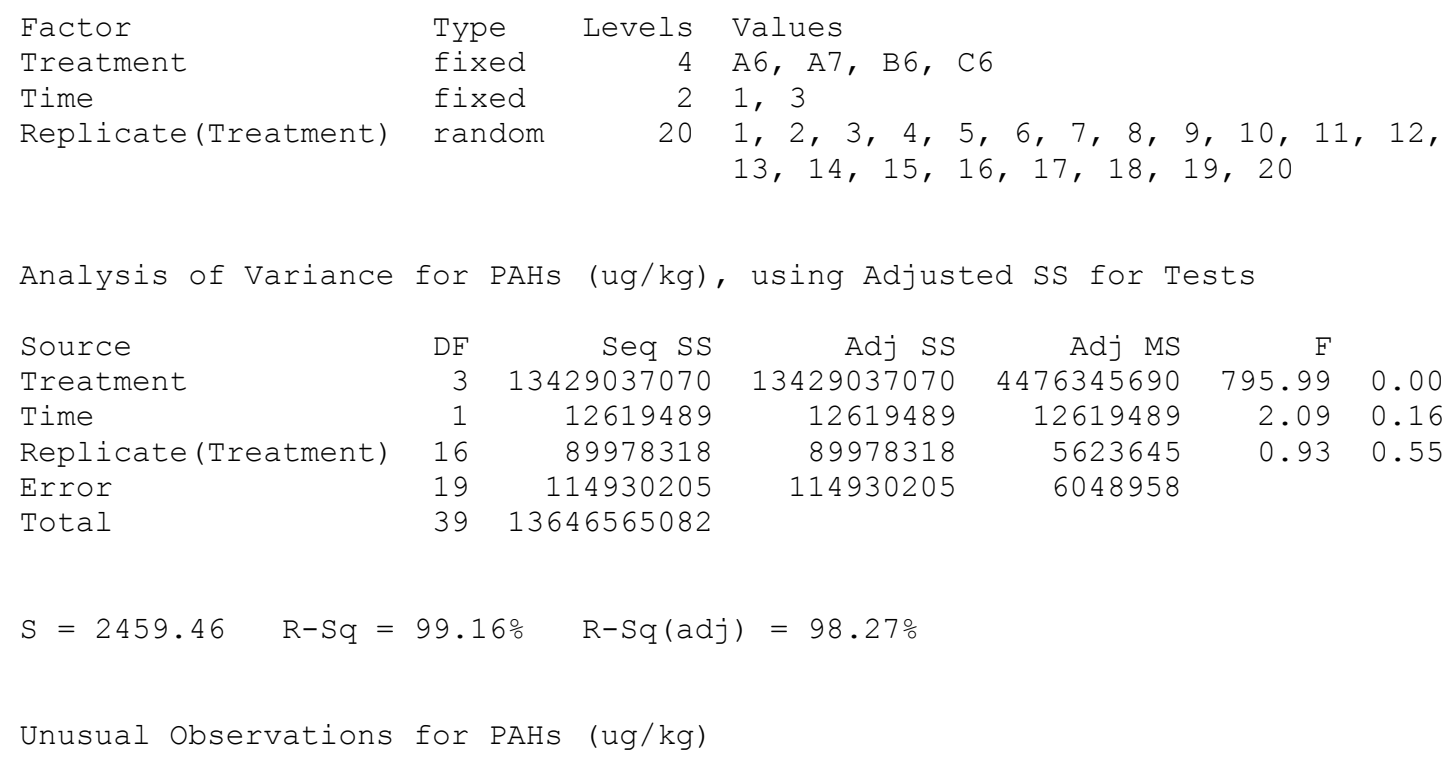




$\begin{array}{rrrrrr}\text { Obs } & \text { (ug/kg) } & \text { Fit } & \text { SE Fit } & \text { Residual } & \text { St Resid } \\ 12 & 44616.0 & 38696.2 & 1782.1 & 5919.8 & 3.49 \mathrm{R} \\ 32 & 31653.0 & 37572.8 & 1782.1 & -5919.8 & -3.49 \mathrm{R}\end{array}$

$\mathrm{R}$ denotes an observation with a large standardized residual.

\section{Residual Plots for PAHs (ug/kg)}

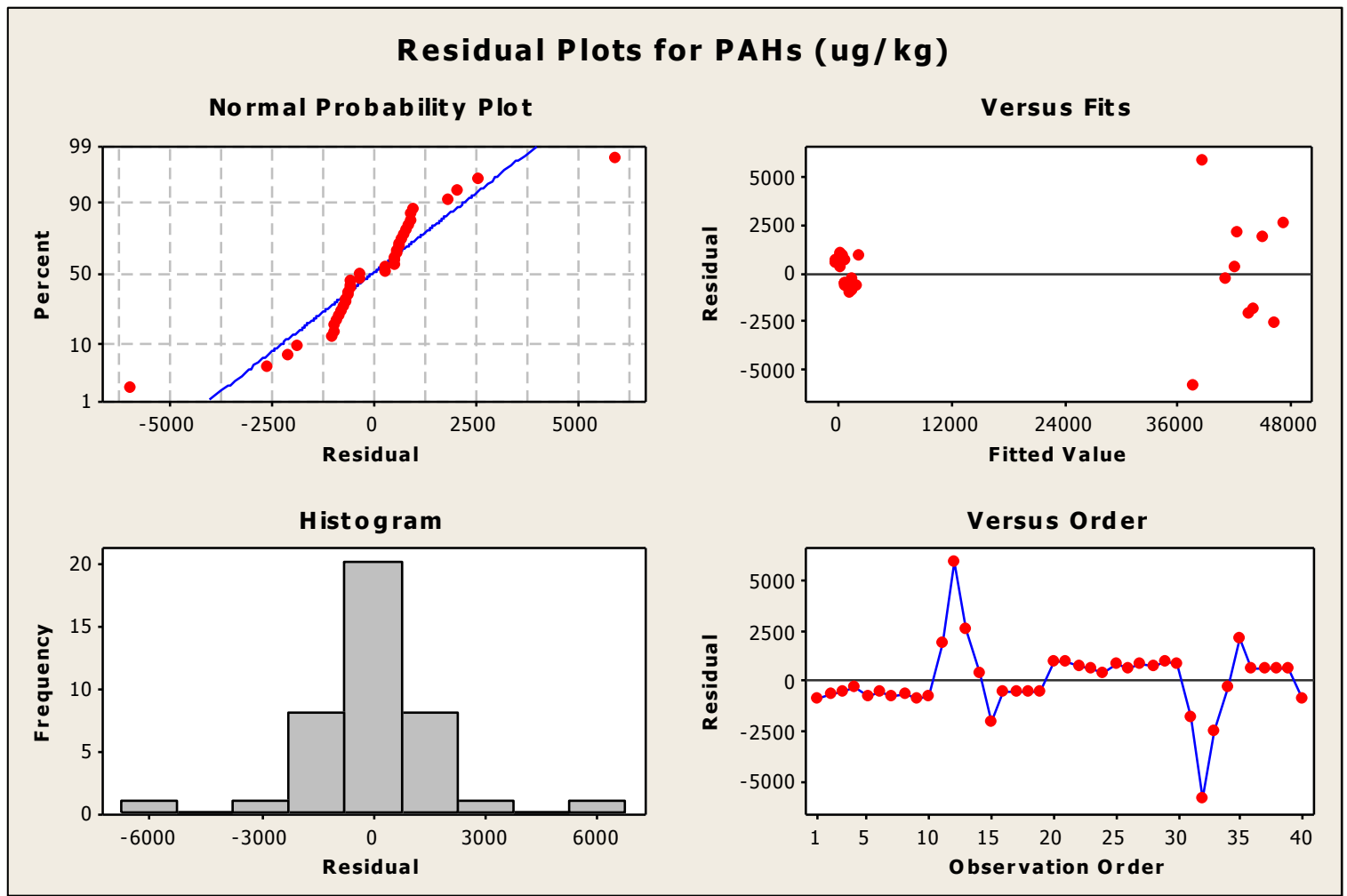

\section{General Linear Model: log(PAHs) versus Treatment, Time, Replicate}

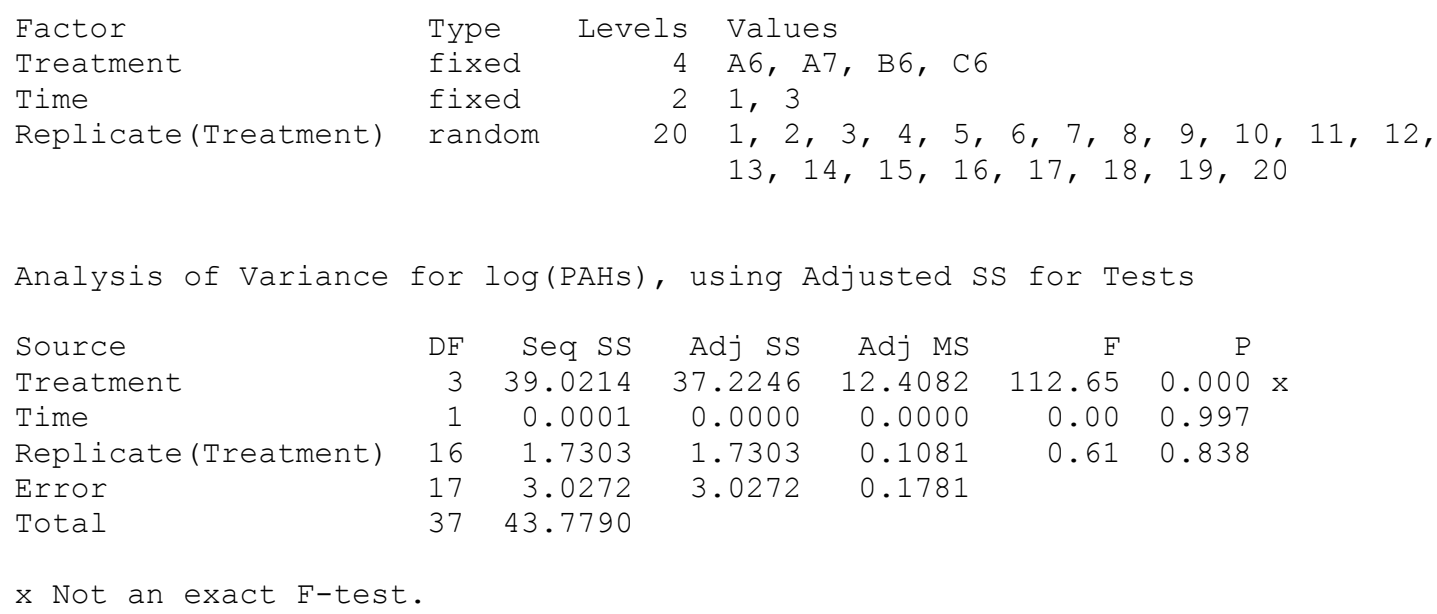


$S=0.421984 \quad R-S q=93.09 \% \quad R-S q(\operatorname{adj})=84.95 \%$

Unusual Observations for log(PAHs)
$\begin{array}{rrrrrr}\text { Obs } & \text { log(PAHs) } & \text { Fit } & \text { SE Fit } & \text { Residual } & \text { St Resid } \\ 20 & 3.48572 & 2.43271 & 0.30656 & 1.05301 & 3.63 \text { R } \\ 37 & 1.53148 & 1.53148 & 0.42198 & 0.00000 & * \text { X } \\ 39 & 2.14613 & 2.14613 & 0.42198 & 0.00000 & \text { X } \\ 40 & 1.38021 & 2.43322 & 0.30656 & -1.05301 & -3.63 \text { R }\end{array}$

$R$ denotes an observation with a large standardized residual.

$\mathrm{X}$ denotes an observation whose $\mathrm{X}$ value gives it large leverage.

\section{Residual Plots for log(PAHs)}

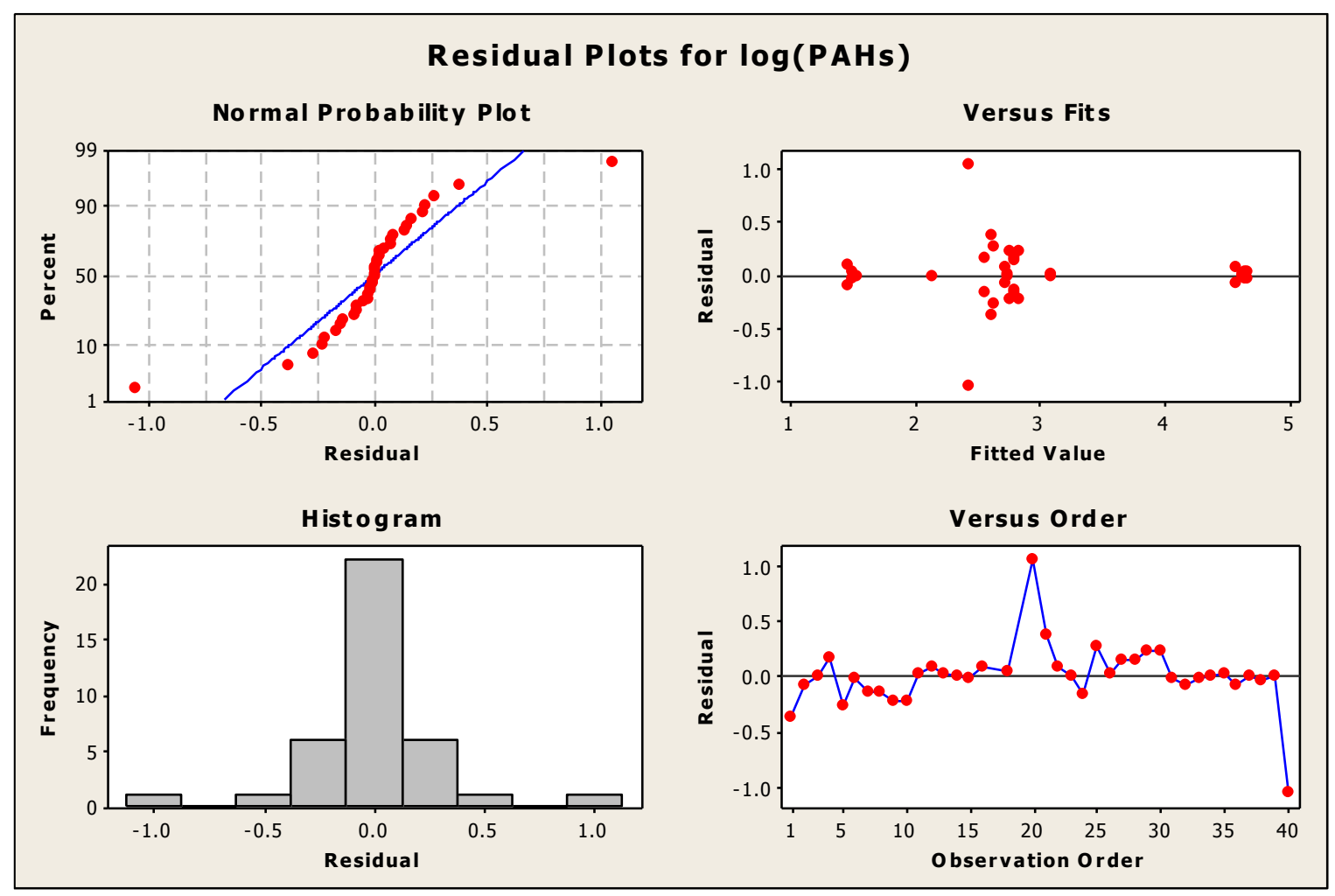

General Linear Model: PCBs (ug/kg) versus Treatment, Time, Replicate

Factor

Treatment

Time

Replicate (Treatment)
Levels Values

$4 \mathrm{~A} 6, \mathrm{~A} 7, \mathrm{~B} 6, \mathrm{C} 6$

21,3

$201,2,3,4,5,6,7,8,9,10,11,12$, $13,14,15,16,17,18,19,20$

Analysis of Variance for PCBs (ug/kg), using Adjusted SS for Tests

Source

$\mathrm{DF}$

Seq SS

Adj SS Adj MS

F $\quad$ P

162 


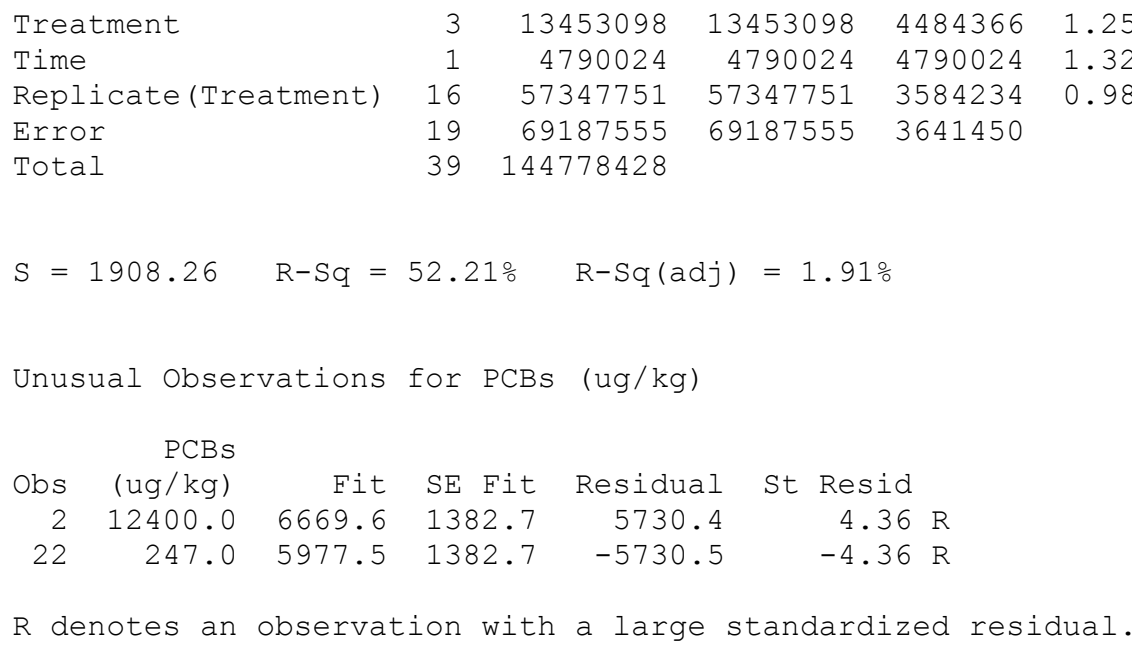

$\begin{array}{rrrr}\text { Fit } & \text { SE Fit } & \text { Residual } & \text { St Resid } \\ 6669.6 & 1382.7 & 5730.4 & 4.36 \mathrm{R} \\ 5977.5 & 1382.7 & -5730.5 & -4.36 \mathrm{R}\end{array}$

$\mathrm{R}$ denotes an observation with a large standardized residual.

\section{Residual Plots for PCBs (ug/kg)}

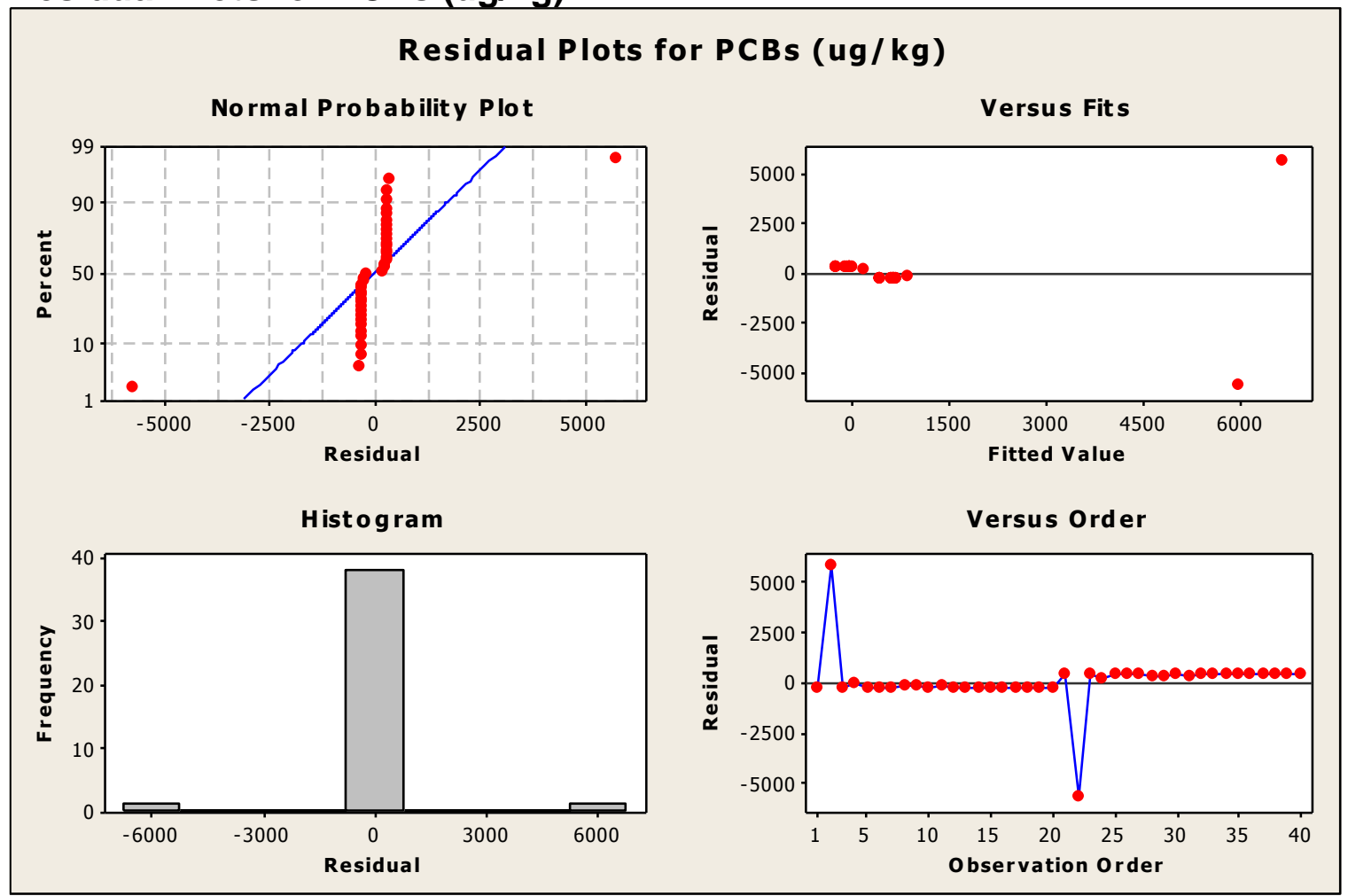

General Linear Model: log(PCBs) versus Treatment, Time, Replicate

$\begin{array}{llrl}\text { Factor } & \text { Type } & \text { Levels } & \text { Values } \\ \text { Treatment } & \text { fixed } & 4 & \text { A6, A7, B6, C6 } \\ \text { Time } & \text { fixed } & 2 & 1,3 \\ \text { Replicate (Treatment) } & \text { random } & 20 & 1,2,3,4,5,6,7,8,9,10,11,12,\end{array}$




\begin{tabular}{|c|c|c|c|c|c|c|}
\hline Source & $\mathrm{DF}$ & Seq SS & Adj $S S$ & Adj MS & $\mathrm{F}$ & $\mathrm{P}$ \\
\hline Treatment & 3 & 3.66557 & 3.66557 & 1.22186 & 19.86 & 0.000 \\
\hline Time & 1 & 0.65893 & 0.65893 & 0.65893 & 10.62 & 0.004 \\
\hline Replicate (Treatment) & 16 & 0.98447 & 0.98447 & 0.06153 & 0.99 & 0.501 \\
\hline Error & 19 & 1.17846 & 1.17846 & 0.06202 & & \\
\hline Total & 39 & 6.48743 & & & & \\
\hline
\end{tabular}

Unusual Observations for $\log (\mathrm{PCBS})$

$\begin{array}{rrrrrrr}\text { Obs } & \text { log(PCBs) } & \text { Fit } & \text { SE Fit } & \text { Residual } & \text { St Resid } \\ 2 & 4.09342 & 3.37141 & 0.18045 & 0.72201 & 4.21 & R \\ 22 & 2.39270 & 3.11471 & 0.18045 & -0.72201 & -4.21 & R\end{array}$

$\mathrm{R}$ denotes an observation with a large standardized residual.

\section{Residual Plots for log(PCBs)}

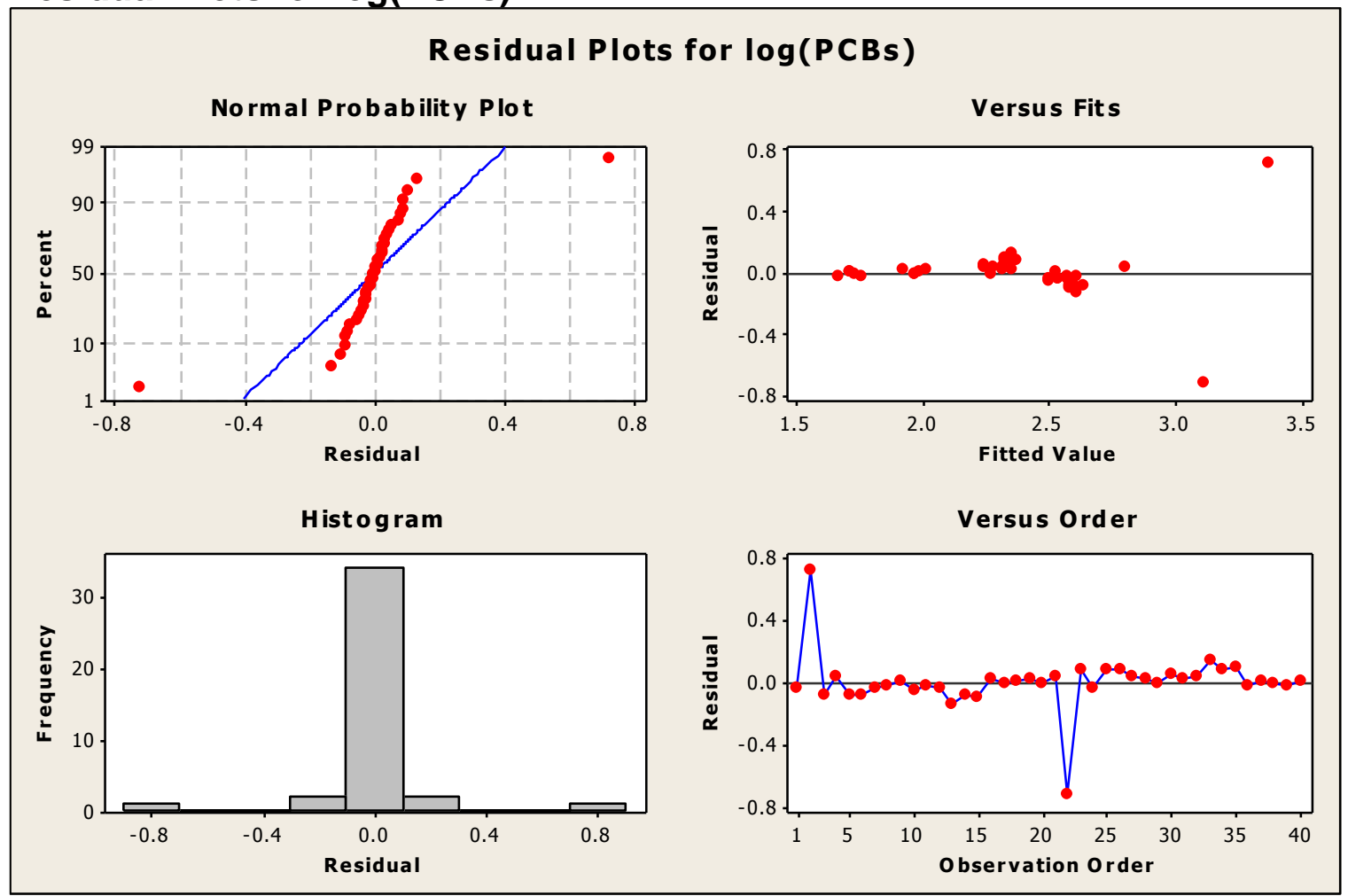

\section{General Linear Model: TCDD TEQ (ng/kg) versus Treatment, Time, Replicate}

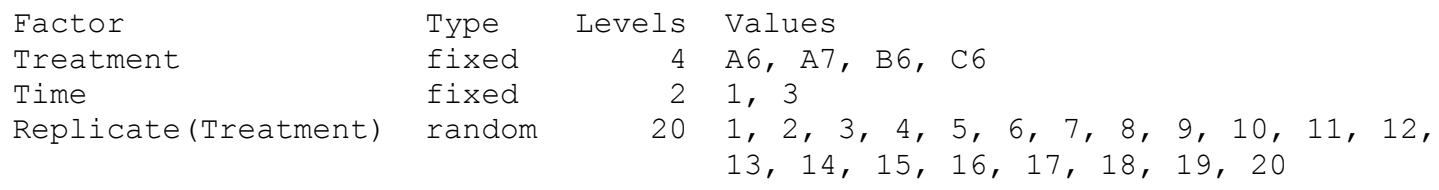




$\begin{array}{lrrrrrr}\text { Source } & \text { DF } & \text { Seq SS } & \text { Adj SS } & \text { Adj MS } & \text { F } & \text { P } \\ \text { Treatment } & 3 & 547152 & 547152 & 182384 & 974.09 & 0.000 \\ \text { Time } & 1 & 4537 & 4537 & 4537 & 14.37 & 0.001 \\ \text { Replicate(Treatment) } & 16 & 2996 & 2996 & 187 & 0.59 & 0.852 \\ \text { Error } & 19 & 6000 & 6000 & 316 & & \\ \text { Total } & 39 & 560685 & & & & \\ & & & & & & \\ \text { S }=17.7709 \quad \text { R-Sq }=98.93 \% & \text { R-Sq(adj) }=97.80 \% & \end{array}$

\section{Residual Plots for TCDD TEQ (ng/kg)}

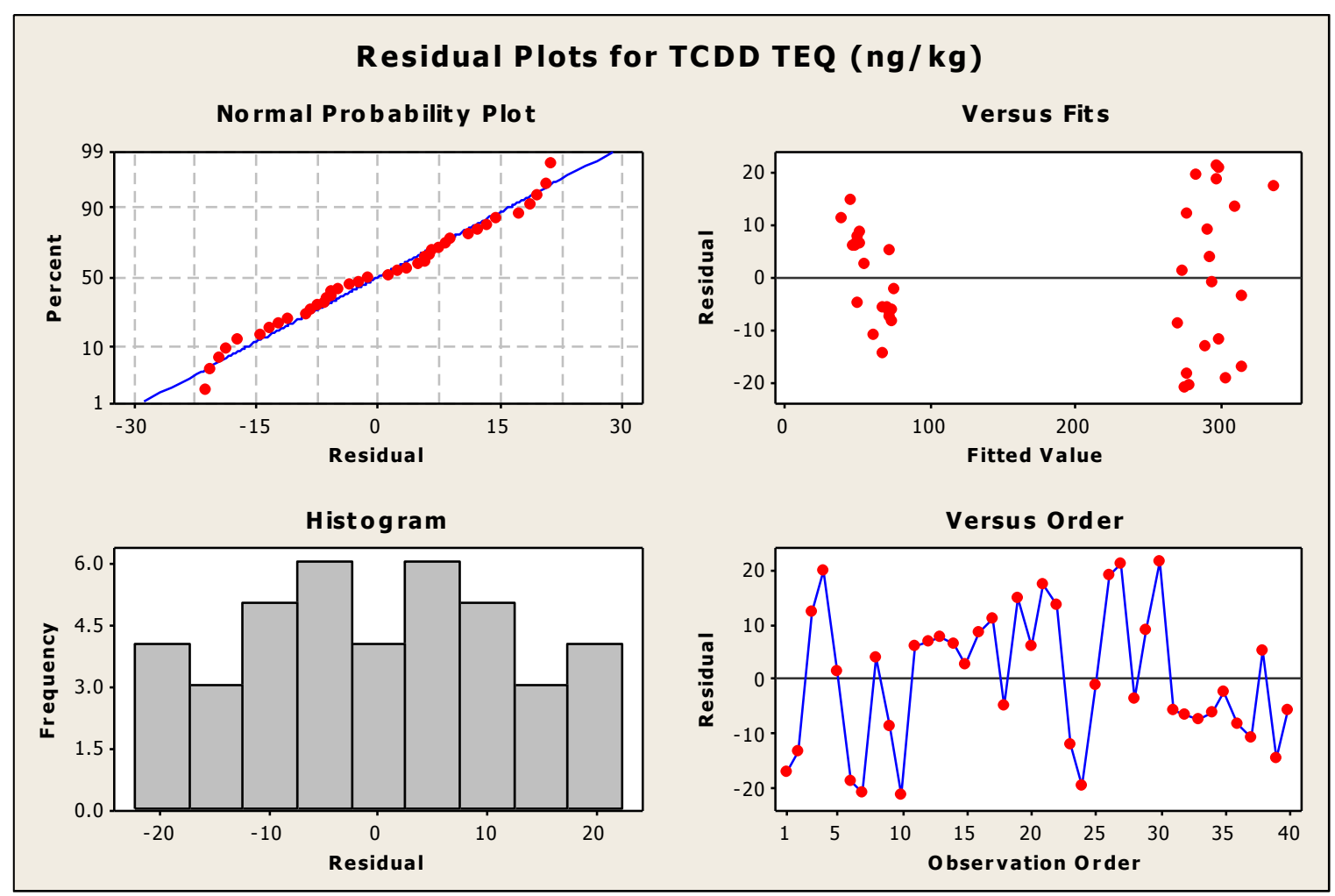

\section{General Linear Model: Total EFH (C8-C4 versus Treatment, Time, Replicate}

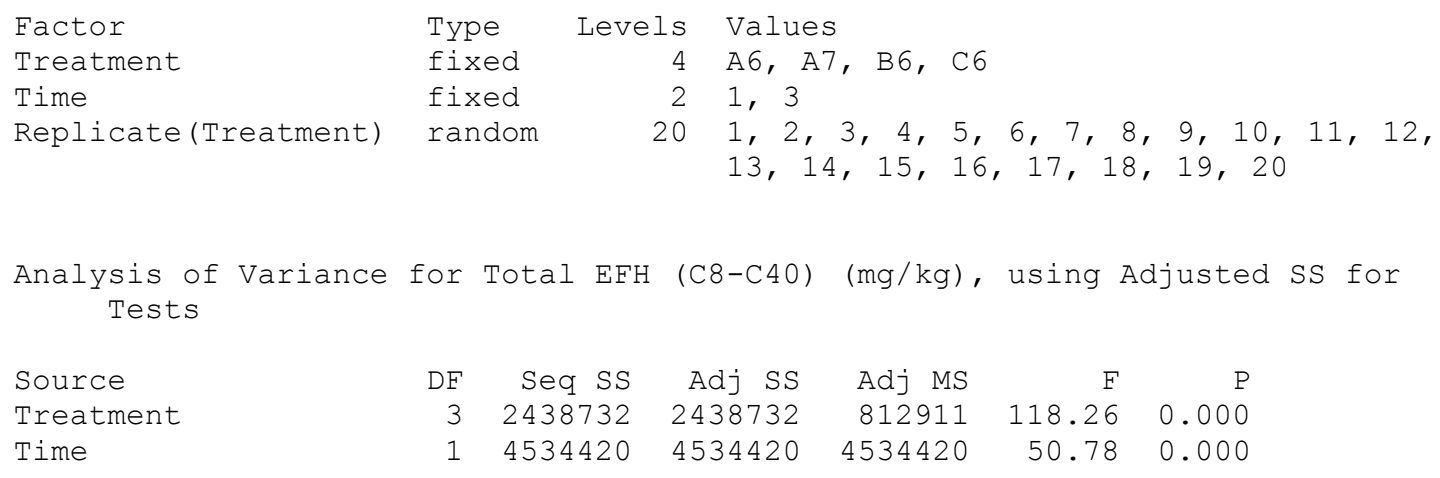




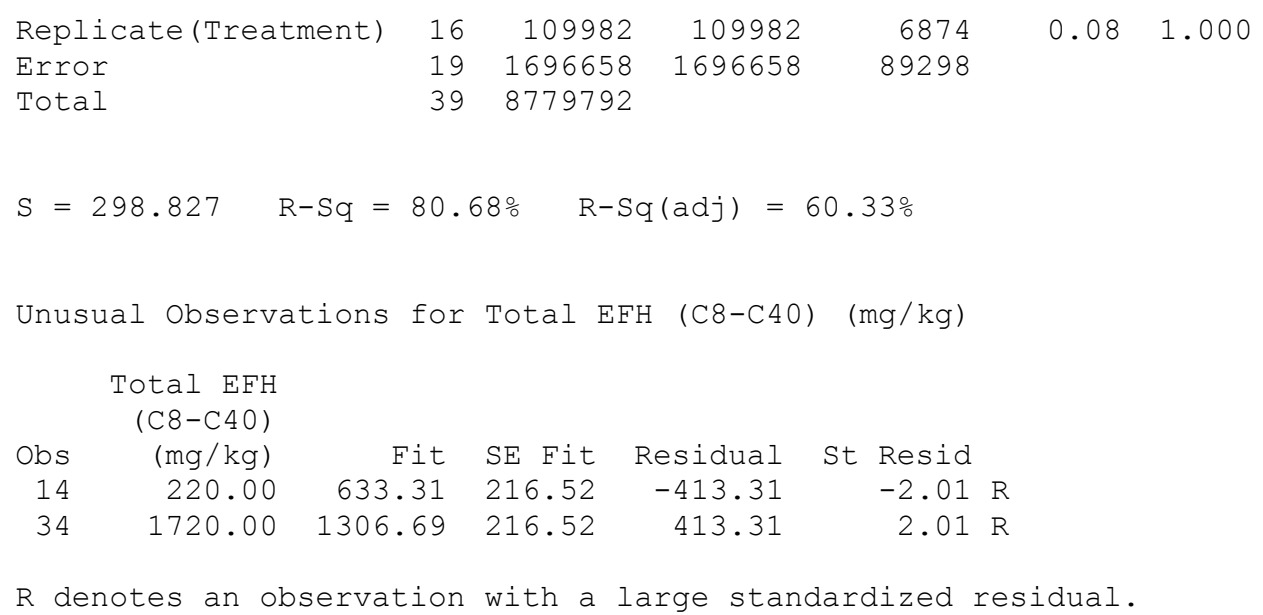

Residual Plots for Total EFH (C8-C40) (mg/kg)

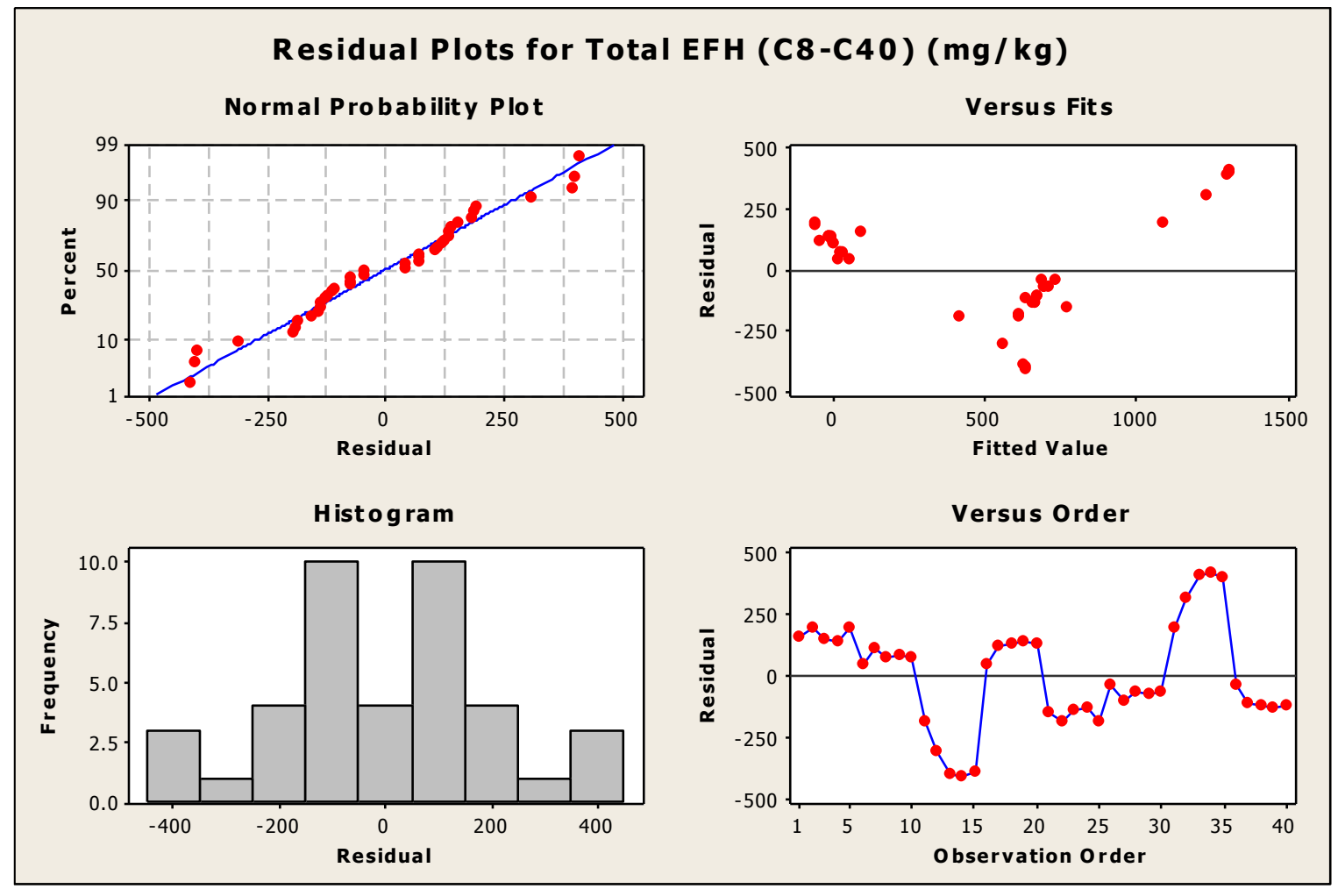

General Linear Model: log(TotalEFH) versus Treatment, Time, Replicate

$\begin{array}{llrl}\text { Factor } & \text { Type } & \text { Levels } & \text { Values } \\ \text { Treatment } & \text { fixed } & 4 \text { A6, A7, B6, C6 } \\ \text { Time } & \text { fixed } & 2 \text { (1, 3 } & \\ \text { Replicate (Treatment) } & \text { random } & 20 & 1,2,3,4,5,6,7,8,9,10,11,12, \\ & & & 13,14,15,16,17,18,19,20\end{array}$


Analysis of Variance for log(TotalEFH), using Adjusted SS for Tests

\begin{tabular}{|c|c|c|c|c|c|c|}
\hline Source & $\mathrm{DF}$ & Seq SS & Adj $S S$ & Adj MS & $\mathrm{F}$ & $\mathrm{P}$ \\
\hline Treatment & 3 & 1.11243 & 1.11243 & 0.37081 & 55.52 & 0.000 \\
\hline Time & 1 & 5.34375 & 5.34375 & 5.34375 & 449.81 & 0.000 \\
\hline Replicate (Treatment) & 16 & 0.10686 & 0.10686 & 0.00668 & 0.56 & 0.875 \\
\hline Error & 19 & 0.22572 & 0.22572 & 0.01188 & & \\
\hline Total & 39 & 6.78876 & & & & \\
\hline
\end{tabular}

Unusual Observations for log(TotalEFH)

\begin{tabular}{|c|c|c|c|c|c|c|}
\hline $\mathrm{Obs}$ & $\log ($ TotalEFH) & Fit & SE Fit & Residual & St & Resid \\
\hline 1 & 2.39794 & 2.22757 & 0.07897 & 0.17037 & & 2.27 \\
\hline 16 & 1.77815 & 1.93003 & 0.07897 & -0.15188 & & -2.02 \\
\hline 21 & 2.78821 & 2.95858 & 0.07897 & -0.17037 & & -2.27 \\
\hline 36 & 2.81291 & 2.66104 & 0.07897 & 0.15188 & & 2.02 \\
\hline
\end{tabular}

$\mathrm{R}$ denotes an observation with a large standardized residual.

\section{Residual Plots for log(TotalEFH)}

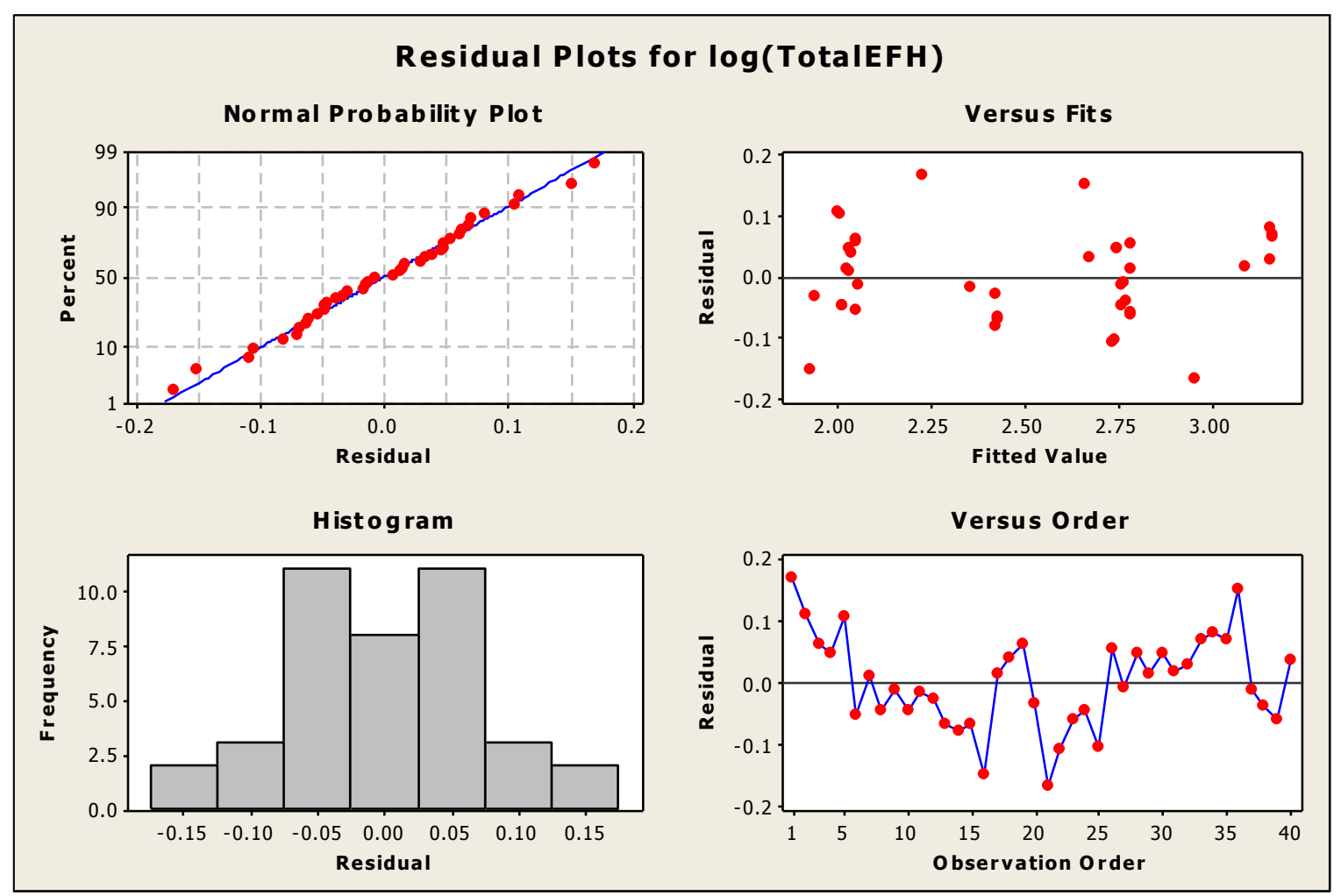


Appendix I: Microcosm Data and Graphs

Table 9: Microcosm soil pH values and statistics

\begin{tabular}{lllllll}
\hline Microcosm ID/Type & \multicolumn{2}{l}{ Average Value } & \multicolumn{2}{l}{ Standard Deviation } & \multicolumn{2}{l}{ Standard Error } \\
\hline $\begin{array}{l}\text { Sampling time } \\
\text { (month/days) }\end{array}$ & $\begin{array}{l}\text { Feb/0 Jun/126 } \\
\text { days }\end{array}$ & $\begin{array}{l}\text { days } \\
\text { dab/0 days }\end{array}$ & $\begin{array}{l}\text { Jun/126 } \\
\text { days }\end{array}$ & Feb/0 days & $\begin{array}{l}\text { Jun/126 } \\
\text { days }\end{array}$ \\
\hline A1 Nutrients & 6.53 & 6.28 & 0.04 & 0.06 & 0.02 & 0.03 \\
\hline A2 Soya lecithin & 5.87 & 6.31 & 0.03 & 0.19 & 0.01 & 0.08 \\
\hline A3 Rice hulls & 6.60 & 6.24 & 0.07 & 0.17 & 0.03 & 0.08 \\
\hline $\begin{array}{l}\text { A4 Nutrients+rice hulls+P. } \\
\text { chrysosporium }\end{array}$ & 6.44 & 6.35 & 0.06 & 0.18 & 0.03 & 0.08 \\
\hline $\begin{array}{l}\text { A5 Nutrients+soya } \\
\text { lecithin+rice hulls+P. } \\
\text { chrysosporium }\end{array}$ & 6.03 & 6.18 & 0.03 & 0.09 & 0.01 & 0.04 \\
\hline A6 Unamended site A & 6.64 & 6.30 & 0.03 & 0.02 & 0.01 & 0.01 \\
\hline B6 Unamended site B & 6.84 & 6.68 & 0.03 & 0.05 & 0.01 & 0.02 \\
\hline C6 Unamended site C & 7.35 & 7.33 & 0.05 & 0.05 & 0.02 & 0.02 \\
\hline $\begin{array}{l}\text { A7 Unamended, gamma- } \\
\text { irradiated site A }\end{array}$ & 6.676 & $\mathrm{~N} / \mathrm{A}$ & 0.038471 & $\mathrm{~N} / \mathrm{A}$ & 0.017205 & $\mathrm{~N} / \mathrm{A}$ \\
\hline
\end{tabular}

Table 10: Microcosm soil TOC concentrations and statistics

\begin{tabular}{|c|c|c|c|c|c|c|}
\hline \multirow{2}{*}{$\begin{array}{l}\text { Microcosm ID/Type } \\
\text { Sampling time } \\
\text { (month/days) }\end{array}$} & \multicolumn{2}{|c|}{$\begin{array}{l}\text { Average } \\
\text { Concentration } \\
\text { (mg/kg) }\end{array}$} & \multicolumn{2}{|c|}{$\begin{array}{l}\text { Standard } \\
\text { Deviation }\end{array}$} & \multicolumn{2}{|c|}{ Standard Error } \\
\hline & $\begin{array}{r}\text { Feb/0 } \\
\text { days }\end{array}$ & $\begin{array}{r}\text { Jun/126 } \\
\text { days } \\
\end{array}$ & $\begin{array}{r}\mathrm{Feb} / 0 \\
\text { days }\end{array}$ & $\begin{array}{r}\text { Jun/126 } \\
\text { days } \\
\end{array}$ & $\begin{array}{r}\mathrm{Feb} / 0 \\
\text { days }\end{array}$ & $\begin{array}{r}\text { Jun/126 } \\
\text { days } \\
\end{array}$ \\
\hline A1 nutrient & 11976 & 7986 & 7266 & 2594 & 3250 & 1160 \\
\hline A2 soya lecithin & 24960 & 12524 & 9630 & 2892 & 4307 & 1294 \\
\hline A3 rice hulls & 36420 & 23820 & 17833 & 6181 & 7975 & 2764 \\
\hline $\begin{array}{l}\text { A4 nutrients+rice hulls+P. } \\
\text { chrysosporium }\end{array}$ & 33464 & 19840 & 22393 & 3331 & 10015 & 1490 \\
\hline $\begin{array}{l}\text { A5 nutrients+soya } \\
\text { lecithin+rice hulls+P. } \\
\text { chrysosporium }\end{array}$ & 37640 & 23740 & 11336 & 4426 & 5070 & 1979 \\
\hline A6 unamended site $A$ & 11298 & 9268 & 5606 & 3056 & 2507 & 1367 \\
\hline B6 unamended site B & 61060 & 37530 & 19453 & 28015 & 8700 & 12529 \\
\hline C6 unamended site $\mathrm{C}$ & 3236 & 2770 & 1023 & 1231 & 458 & 551 \\
\hline $\begin{array}{l}\text { A7 gamma-irradiated } \\
\text { unamended site a }\end{array}$ & 10830 & $\mathrm{~N} / \mathrm{A}$ & 3732 & $\mathrm{~N} / \mathrm{A}$ & 1669 & $\mathrm{~N} / \mathrm{A}$ \\
\hline
\end{tabular}




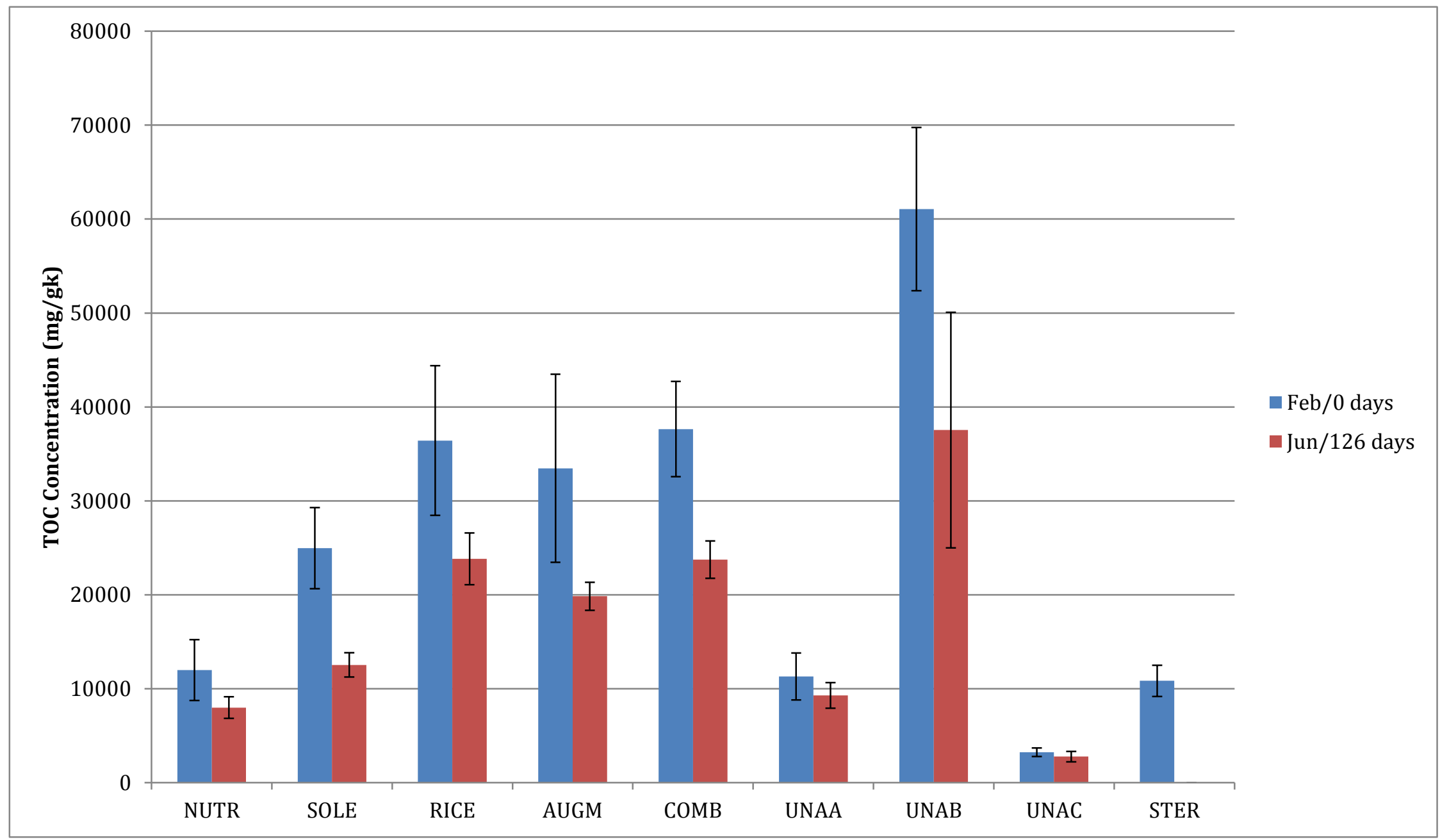

Figure 68: TOC in microcosms during incubation 
Table 11: Microcosm soil Nitrate/Nitrate concentrations and statistics

\begin{tabular}{|c|c|c|c|c|c|c|}
\hline Microcosm ID/Type & $\begin{array}{l}\text { Average Conc } \\
(\mathrm{mg} / \mathrm{kg})\end{array}$ & entration & $\begin{array}{l}\text { Standaı } \\
\text { Deviatic }\end{array}$ & & Standar & d Error \\
\hline Sampling time (month/days) & Feb/0 days & $\begin{array}{l}\text { Jun/126 } \\
\text { days }\end{array}$ & $\begin{array}{l}\text { Feb/0 } \\
\text { days }\end{array}$ & $\begin{array}{l}\text { Jun/126 } \\
\text { days }\end{array}$ & $\begin{array}{l}\text { Feb/0 } \\
\text { days }\end{array}$ & $\begin{array}{l}\text { Feb/0 } \\
\text { days }\end{array}$ \\
\hline A1 nutrient & 701 & 991 & 146 & 126 & 65 & 57 \\
\hline A2 soya lecithin & 772 & 1148 & 104 & 138 & 47 & 62 \\
\hline A3 rice hulls & 856 & 1066 & 181 & 657 & 81 & 294 \\
\hline $\begin{array}{l}\text { A4 nutrients+rice hulls+P. } \\
\text { chrysosporium }\end{array}$ & 884 & 1103 & 464 & 149 & 207 & 66 \\
\hline $\begin{array}{l}\text { A5 nutrients+soya } \\
\text { lecithin+rice hulls+P. } \\
\text { chrysosporium }\end{array}$ & 996 & 1584 & 117 & 454 & 52 & 203 \\
\hline A6 unamended site $A$ & 834 & 1168 & 198 & 318 & 88 & 142 \\
\hline B6 unamended site B & 1814 & 2178 & 437 & 229 & 195 & 103 \\
\hline C6 unamended site C & 186 & 143 & 41 & 82 & 18 & 37 \\
\hline $\begin{array}{l}\text { A7 gamma-irradiated } \\
\text { unamended site a }\end{array}$ & 679 & $\mathrm{~N} / \mathrm{A}$ & 77 & $\mathrm{~N} / \mathrm{A}$ & 34 & $\mathrm{~N} / \mathrm{A}$ \\
\hline
\end{tabular}




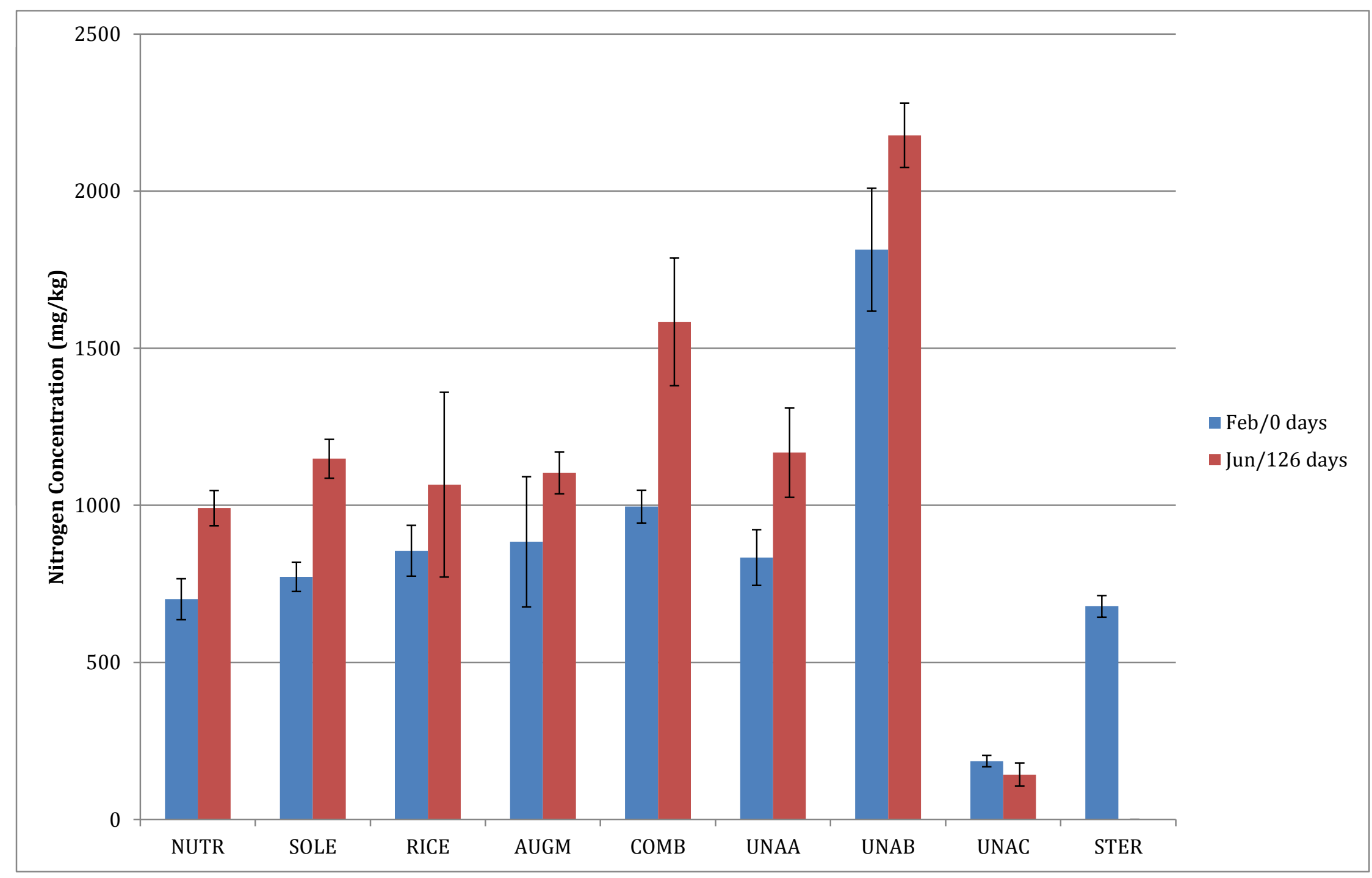

Figure 69: Nitrogen in microcosms during incubation 
Table 12: Microcosm soil moisture content and statistics

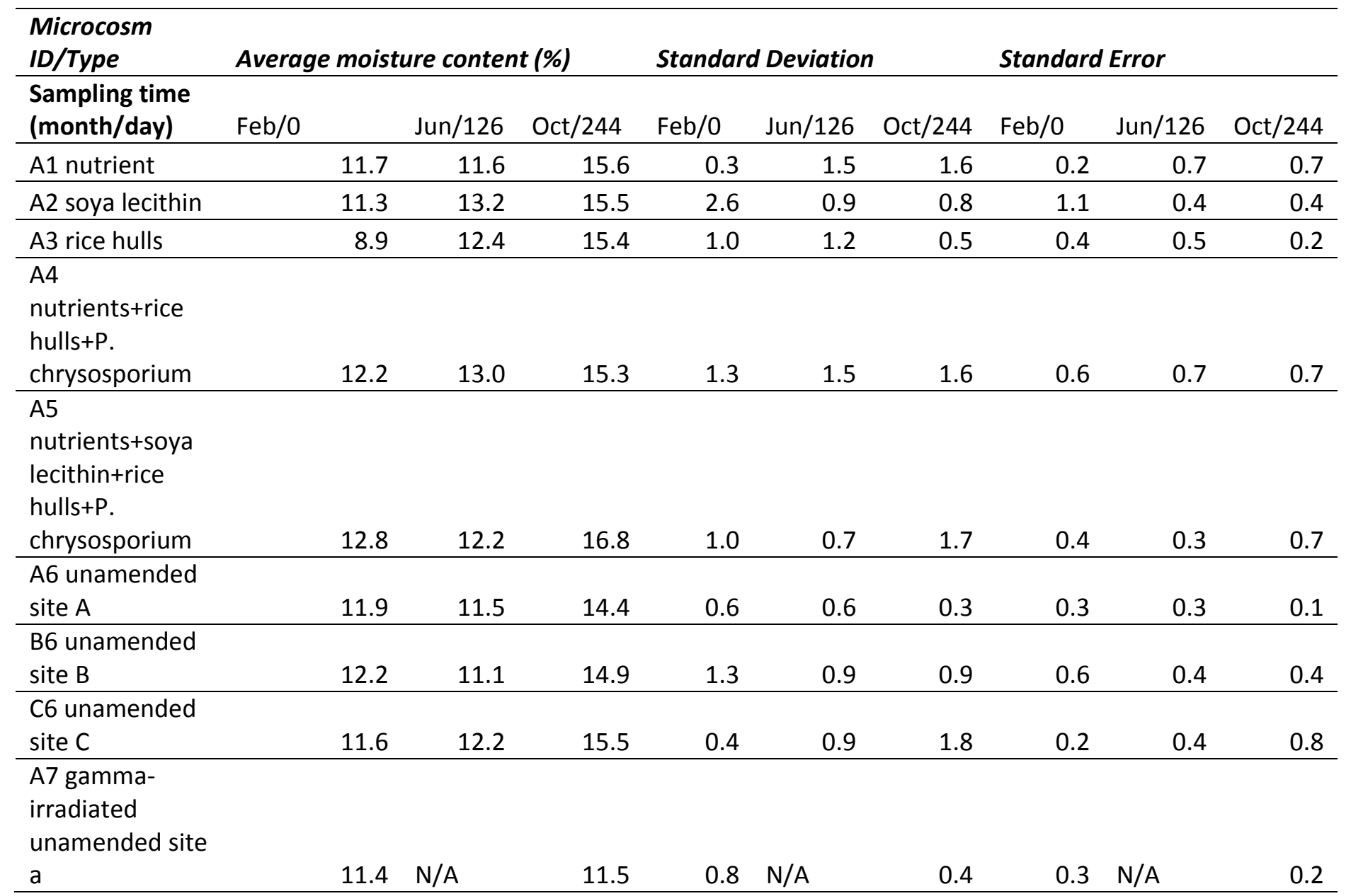




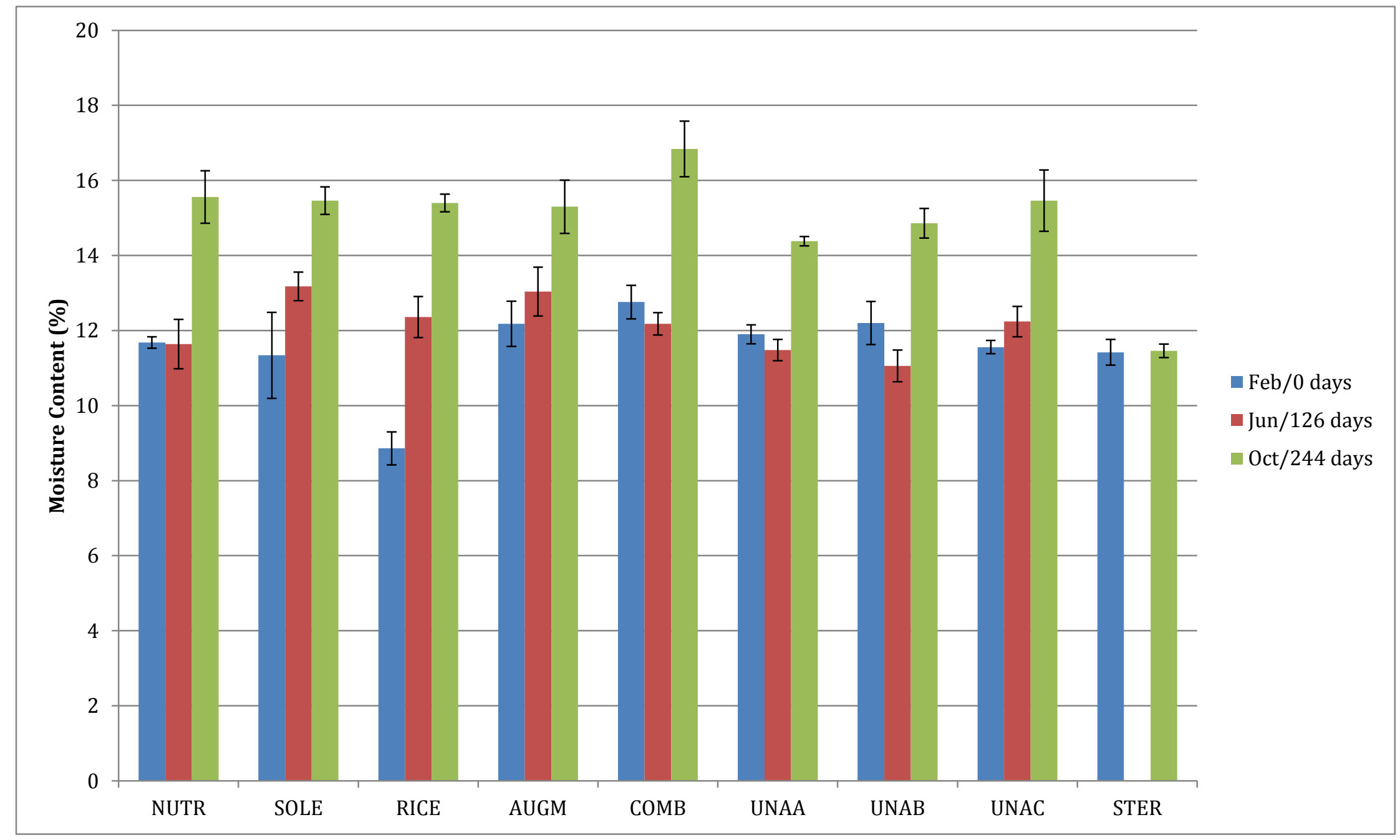

Figure 70: Microcosm moisture content during incubation 
Table 13: Microcosm soil total EFH concentrations and statistics

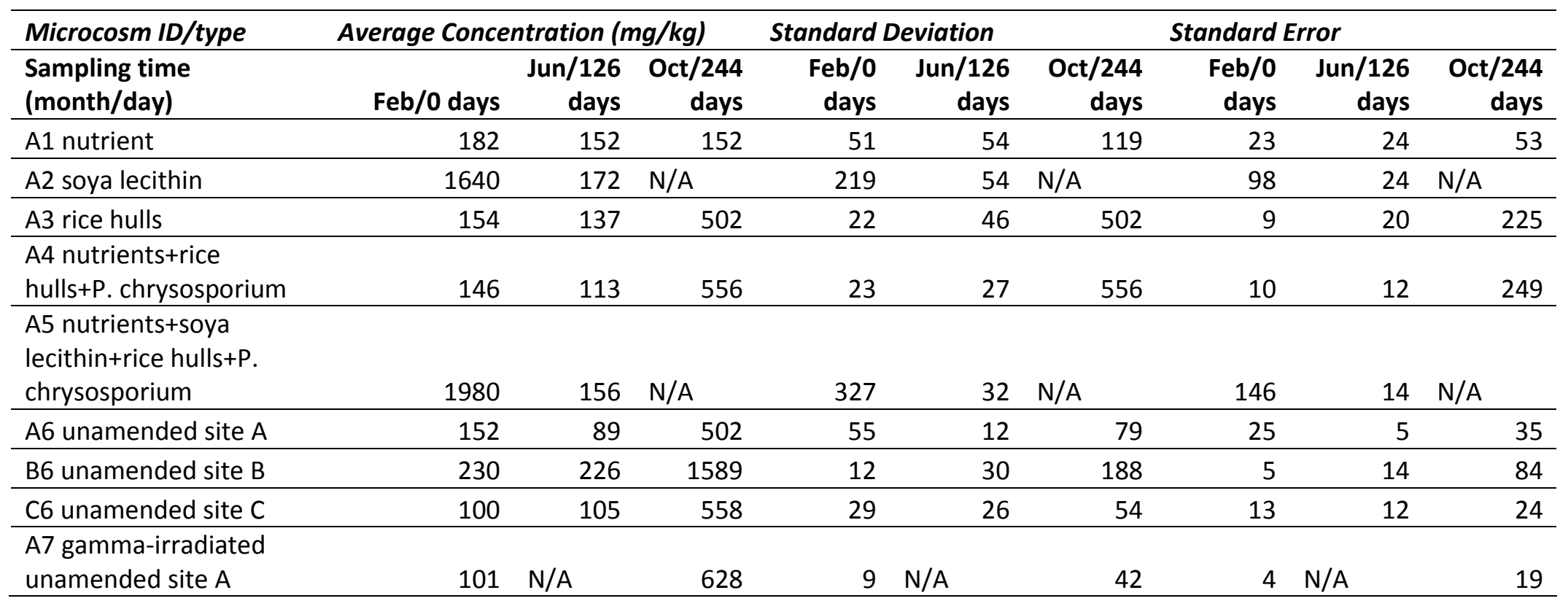


Table 14: Microcosm total PAH concentrations and statistics

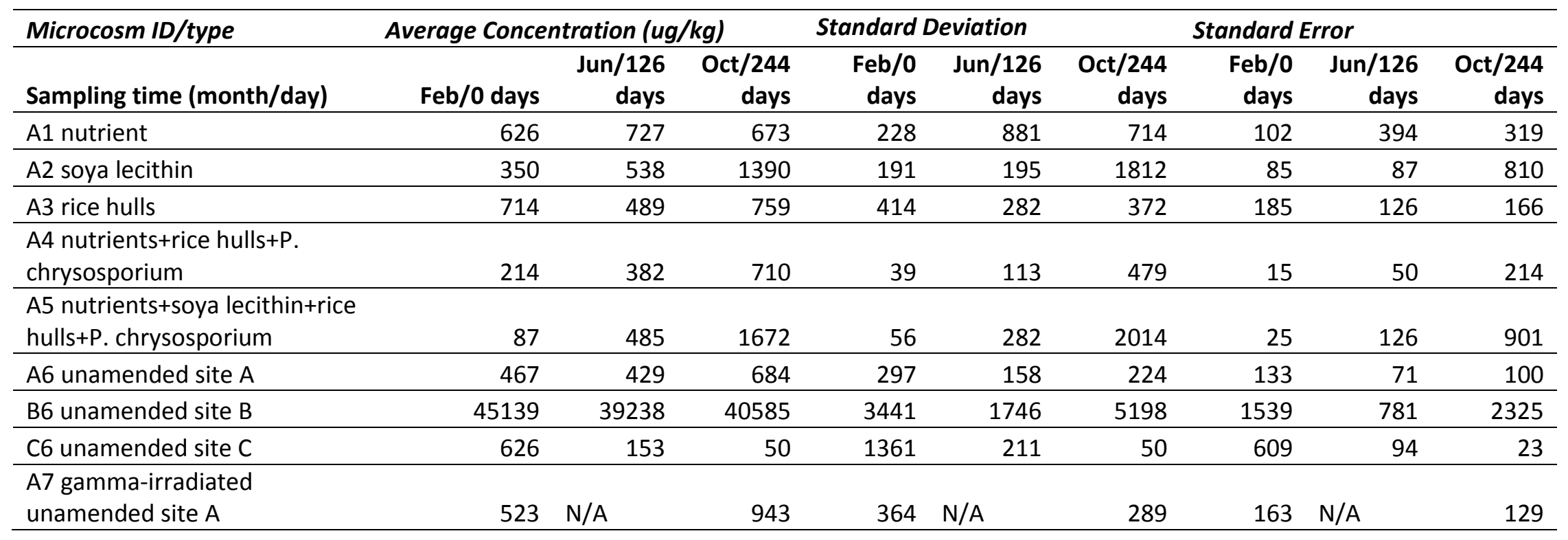


Table 15: Microcosm soil total PCB concentrations and statistics

\begin{tabular}{|c|c|c|c|c|c|c|c|c|c|}
\hline \multirow{2}{*}{$\begin{array}{l}\text { Microcosm ID/type } \\
\text { Sampling time (month/day) }\end{array}$} & \multicolumn{3}{|c|}{ Average Concentration (ug/kg) } & \multicolumn{3}{|c|}{ Standard Deviation } & \multicolumn{3}{|c|}{ Standard Error } \\
\hline & Feb/0 days & $\begin{array}{l}\text { Jun/126 } \\
\text { days }\end{array}$ & $\begin{array}{l}\text { Oct } / 244 \\
\text { days }\end{array}$ & $\begin{array}{l}\text { Feb/0 } \\
\text { days }\end{array}$ & $\begin{array}{l}\text { Jun/126 } \\
\text { days }\end{array}$ & $\begin{array}{l}\text { Oct } / 244 \\
\text { days }\end{array}$ & $\begin{array}{l}\text { Feb/0 } \\
\text { days }\end{array}$ & $\begin{array}{l}\text { Jun/126 } \\
\text { days }\end{array}$ & $\begin{array}{l}\text { Oct } / 244 \\
\text { days }\end{array}$ \\
\hline A1 nutrient & 326.4 & 285.6 & 215 & 81.36523 & 54.6562 & 37.22902 & 36.38764 & 24.44299 & 16.64932 \\
\hline A2 soya lecithin & 448.2 & 277.6 & 197.4 & 214.9353 & 46.59184 & 34.07785 & 96.12201 & 20.83651 & 15.24008 \\
\hline A3 rice hulls & 394 & 286 & 186.2 & 98.66357 & 104.8308 & 43.47643 & 44.12369 & 46.88177 & 19.44325 \\
\hline $\begin{array}{l}\text { A4 nutrients+rice hulls+P. } \\
\text { chrysosporium }\end{array}$ & 378 & 234 & 240.2 & 101.4569 & 10.41633 & 19.17551 & 45.3729 & 4.658326 & 8.575547 \\
\hline $\begin{array}{l}\text { A5 nutrients+soya } \\
\text { lecithin+rice hulls+P. } \\
\text { chrysosporium }\end{array}$ & 336.2 & 291.4 & 217.8 & 19.46022 & 43.51781 & 44.81852 & 8.702873 & 19.46176 & 20.04345 \\
\hline A6 unamended site $A$ & 2811.8 & 251.4 & 263 & 5362.195 & 17.7426 & 49.86482 & 2398.047 & 7.934734 & 22.30022 \\
\hline B6 unamended site B & 329.2 & 414 & 260.6 & 37.66563 & 33.61547 & 30.66431 & 16.84458 & 15.0333 & 13.7135 \\
\hline C6 unamended site C & 95.4 & 97.2 & 51.2 & 8.414274 & 5.674504 & 3.563706 & 3.762978 & 2.537716 & 1.593738 \\
\hline $\begin{array}{l}\text { A7 gamma-irradiated } \\
\text { unamended site } A\end{array}$ & 323.8 & & 217 & 27.98571 & & 30.8788 & 12.51559 & & 13.80942 \\
\hline
\end{tabular}


Table 16: Microcosm total dioxin concentration and statistics

\begin{tabular}{|c|c|c|c|c|c|c|c|c|c|}
\hline Microcosm ID/type & \multicolumn{3}{|c|}{ Average Concentration (ng/kg) } & \multicolumn{2}{|c|}{ Standard Deviation } & \multicolumn{3}{|c|}{ Standard Error } & \multirow[b]{2}{*}{$\begin{array}{r}\text { Oct } / 244 \\
\text { days }\end{array}$} \\
\hline Sampling time (month/day) & Feb/0 days & $\begin{array}{r}\text { Jun/126 } \\
\text { days }\end{array}$ & $\begin{array}{r}\text { Oct } / 244 \\
\text { days }\end{array}$ & $\begin{array}{r}\text { Feb/0 } \\
\text { days }\end{array}$ & $\begin{array}{r}\text { Jun } / 126 \\
\text { days }\end{array}$ & $\begin{array}{r}\text { Oct/244 } \\
\text { days }\end{array}$ & $\begin{array}{r}\text { Feb/0 } \\
\text { days }\end{array}$ & $\begin{array}{r}\text { Jun/126 } \\
\text { days }\end{array}$ & \\
\hline A1 nutrient & 98898 & 79230 & 126710 & 11141 & 3779 & 57719 & 4982 & 1690 & 25813 \\
\hline A2 soya lecithin & 99547 & 84227 & 88048 & 6749 & 14579 & 4316 & 3018 & 6520 & 1930 \\
\hline A3 rice hulls & 89064 & 85548 & 93723 & 6327 & 19916 & 11257 & 2830 & 8907 & 5034 \\
\hline $\begin{array}{l}\text { A4 nutrients+rice hulls+P. } \\
\text { chrysosporium }\end{array}$ & 116316 & 90113 & 85415 & 51418 & 20613 & 85415 & 22995 & 9219 & 38199 \\
\hline $\begin{array}{l}\text { A5 nutrients+soya lecithin+rice } \\
\text { hulls+P. chrysosporium }\end{array}$ & 100358 & 88368 & 97854 & 13966 & 12666 & 17633 & 6246 & 5665 & 7886 \\
\hline A6 unamended site $A$ & 99432 & 81967 & 96257 & 9032 & 2047 & 19335 & 4039 & 915 & 8647 \\
\hline B6 unamended site B & 26581 & 26041 & 30452 & 1536 & 2396 & 2397 & 687 & 1072 & 1072 \\
\hline C6 unamended site C & 54509 & 54526 & 55342 & 7608 & 6219 & 12275 & 3403 & 2781 & 5490 \\
\hline $\begin{array}{l}\text { A7 gamma-irradiated } \\
\text { unamended site a }\end{array}$ & 91803 & & 99035 & 18189 & & 7052 & 8135 & & 3154 \\
\hline
\end{tabular}


Table 17: Microcosm soil TCDD TEQ concentrations and statistics

\begin{tabular}{|c|c|c|c|c|c|c|c|c|c|}
\hline Microcosm ID/type & Average Concel & ntration (n & $g / k g)$ & Standard & eviation & & Standard & rror & \\
\hline Sampling time (month/day) & Feb/0 days & $\begin{array}{r}\text { Jun/126 } \\
\text { days }\end{array}$ & $\begin{array}{r}\text { Oct } / 244 \\
\text { days }\end{array}$ & $\begin{array}{r}\text { Feb/0 } \\
\text { days }\end{array}$ & $\begin{array}{r}\text { Jun } / 126 \\
\text { days }\end{array}$ & $\begin{array}{r}\text { Oct/244 } \\
\text { days }\end{array}$ & $\begin{array}{r}\text { Feb/0 } \\
\text { days }\end{array}$ & $\begin{array}{r}\text { Jun/126 } \\
\text { days }\end{array}$ & $\begin{array}{r}\text { Oct } / 244 \\
\text { days }\end{array}$ \\
\hline A1 nutrient & 297 & 247 & 247 & 28 & 20 & 137 & 13 & 9 & 61 \\
\hline A2 soya lecithin & 303 & 264 & 264 & 27 & 27 & 10 & 12 & 12 & 4 \\
\hline $\mathrm{A} 3$ rice hulls & 267 & 250 & 276 & 18 & 15 & 28 & 8 & 7 & 12 \\
\hline $\begin{array}{l}\text { A4 nutrients+rice hulls+P. } \\
\text { chrysosporium }\end{array}$ & 332 & 266 & 282 & 137 & 34 & 11 & 61 & 15 & 5 \\
\hline $\begin{array}{l}\text { A5 nutrients+soya lecithin+rice } \\
\text { hulls+P. chrysosporium }\end{array}$ & 286 & 262 & 314 & 33 & 19 & 41 & 15 & 8 & 18 \\
\hline A6 unamended site $A$ & 288.4 & 263.8 & 308.8 & 12.66096 & 4.32435 & 29.72709 & 5.662155 & 1.933908 & 13.29436 \\
\hline B6 unamended site B & 57.22 & 53.92 & 66.98 & 2.277499 & 2.20159 & 4.350517 & 1.018528 & 0.984581 & 1.94561 \\
\hline C6 unamended site C & 55.14 & 56.24 & 62.38 & 6.518666 & 4.646827 & 10.97802 & 2.915236 & 2.078124 & 4.909521 \\
\hline $\begin{array}{l}\text { A7 gamma-irradiated } \\
\text { unamended site a }\end{array}$ & 266 & & 313.8 & 17.50714 & & 8.074652 & 7.829432 & & 3.611094 \\
\hline
\end{tabular}


Appendix J: Microcosm Soil Temperature Log

Table 18: Microcosm Temperature Data

\begin{tabular}{|c|c|r|r|r|}
\hline Date & $\begin{array}{c}\text { Number of days of } \\
\text { incubation }\end{array}$ & $\begin{array}{c}\text { Average Temp } \\
\text { (degC) }\end{array}$ & $\begin{array}{c}\text { Standard } \\
\text { Deviation }\end{array}$ & $\begin{array}{c}\text { Standard } \\
\text { Error }\end{array}$ \\
\hline $5 / 1 / 2014$ & 77 & 24.2 & 1.0 & 0.5 \\
\hline $5 / 6 / 2014$ & 82 & 19.8 & 1.9 & 0.9 \\
\hline $5 / 11 / 2014$ & 87 & 27.0 & 0.1 & 0.1 \\
\hline $5 / 16 / 2014$ & 92 & 26.9 & 0.7 & 0.3 \\
\hline $5 / 23 / 2014$ & 99 & 26.9 & 0.2 & 0.1 \\
\hline $5 / 28 / 2014$ & 104 & 26.1 & 0.4 & 0.2 \\
\hline $6 / 3 / 2014$ & 110 & 23.5 & 0.3 & 0.1 \\
\hline $6 / 9 / 2014$ & 116 & 24.7 & 0.3 & 0.1 \\
\hline $6 / 16 / 2014$ & 123 & 25.0 & 0.2 & 0.1 \\
\hline $6 / 28 / 2014$ & 135 & 26.2 & 0.6 & 0.3 \\
\hline $6 / 30 / 2014$ & 137 & 25.4 & 0.2 & 0.1 \\
\hline $7 / 7 / 2014$ & 144 & 25.6 & 0.5 & 0.2 \\
\hline $7 / 14 / 2014$ & 151 & 24.3 & 0.2 & 0.1 \\
\hline $7 / 21 / 2014$ & 158 & 26.3 & 0.4 & 0.2 \\
\hline $7 / 28 / 2014$ & 165 & 26.3 & 0.5 & 0.2 \\
\hline $8 / 4 / 2014$ & 172 & 26.3 & 0.5 & 0.2 \\
\hline $8 / 14 / 2014$ & 182 & 29.5 & 1.3 & 0.6 \\
\hline $8 / 26 / 2014$ & 194 & 31.6 & 0.7 & 0.3 \\
\hline $9 / 1 / 2014$ & 200 & 30.9 & 0.6 & 0.3 \\
\hline $9 / 7 / 2014$ & 206 & 31.5 & 0.7 & 0.3 \\
\hline $9 / 15 / 2014$ & 214 & 31.4 & 0.7 & 0.3 \\
\hline $9 / 22 / 2014$ & 221 & 31.2 & 0.7 & 0.3 \\
\hline $9 / 29 / 2014$ & 228 & 30.6 & 0.8 & 0.4 \\
\hline $10 / 6 / 2014$ & 235 & 30.8 & 0.9 & 0.4 \\
\hline $10 / 13 / 2014$ & 242 & 30.4 & 0.7 & 0.3 \\
\hline
\end{tabular}


Appendix K: COI Concentrations, Standard Deviation, and Standard Error

Table 19: Individual compound concentration including standard deviation and error

\begin{tabular}{|c|c|c|c|c|c|c|c|c|c|c|}
\hline Treatment & & NUTR & SOLE & RICE & AUGM & COMB & STER & UNAA & UNAC & UNAB \\
\hline \multicolumn{11}{|l|}{ Feb/0 days } \\
\hline Chemical & Units & \multicolumn{9}{|c|}{ Mean Concentration } \\
\hline $\begin{array}{l}1,2,3,4,6,7,8- \\
\text { HEPTACHLORODIBENZO-P- } \\
\text { DIOXIN }\end{array}$ & $\mathrm{ng} / \mathrm{kg}$ & 10510 & 11740 & 9756 & 11382 & 10826 & 9078 & 9953 & 2798 & 2083 \\
\hline $1,2,3,4,6,7,8$-HPCDF & $\mathrm{ng} / \mathrm{kg}$ & 983 & 861 & 818 & 1249 & 979 & 815 & 870 & 176 & 255 \\
\hline 1,2,3,4,7,8,9-HPCDF & $\mathrm{ng} / \mathrm{kg}$ & 84 & 76 & 72 & 88 & 68 & 69 & 75 & 10 & 19 \\
\hline $\begin{array}{l}\text { 1,2,3,4,7,8-HEXACHLORODIBENZO- } \\
\text { P-DIOXIN }\end{array}$ & $\mathrm{ng} / \mathrm{kg}$ & 83 & 83 & 74 & 92 & 79 & 75 & 81 & 5 & 16 \\
\hline $1,2,3,4,7,8-\mathrm{HXCDF}$ & $\mathrm{ng} / \mathrm{kg}$ & 25 & 22 & 22 & 31 & 24 & 22 & 24 & 3 & 10 \\
\hline $\begin{array}{l}\text { 1,2,3,6,7,8-HEXACHLORODIBENZO- } \\
\text { P-DIOXIN }\end{array}$ & $\mathrm{ng} / \mathrm{kg}$ & 478 & 484 & 429 & 523 & 441 & 430 & 444 & 61 & 80 \\
\hline $1,2,3,6,7,8-\mathrm{HXCDF}$ & $\mathrm{ng} / \mathrm{kg}$ & 31 & 25 & 25 & 55 & 44 & 24 & 26 & 3 & 9 \\
\hline $\begin{array}{l}\text { 1,2,3,7,8,9-HEXACHLORODIBENZO- } \\
\text { P-DIOXIN }\end{array}$ & $\mathrm{ng} / \mathrm{kg}$ & 189 & 190 & 169 & 205 & 173 & 169 & 178 & 14 & 34 \\
\hline $1,2,3,7,8,9-\mathrm{HXCDF}$ & $\mathrm{ng} / \mathrm{kg}$ & 7 & 6 & 6 & 8 & 2 & 4 & 3 & 0 & 3 \\
\hline $\begin{array}{l}\text { 1,2,3,7,8- } \\
\text { PENTACHLORODIBENZOFURAN }\end{array}$ & $\mathrm{ng} / \mathrm{kg}$ & 8 & 8 & 8 & 9 & 7 & 7 & 8 & 1 & 3 \\
\hline $\begin{array}{l}\text { 1,2,3,7,8-PENTACHLORODIBENZO- } \\
\text { P-DIOXIN }\end{array}$ & $\mathrm{ng} / \mathrm{kg}$ & 56 & 53 & 50 & 62 & 50 & 53 & 55 & 2 & 8 \\
\hline $2,3,4,6,7,8-\mathrm{HXCDF}$ & $\mathrm{ng} / \mathrm{kg}$ & 49 & 44 & 42 & 54 & 41 & 42 & 45 & 3 & 13 \\
\hline 2,3,4,7,8-PECDF & $\mathrm{ng} / \mathrm{kg}$ & 12 & 10 & 10 & 13 & 10 & 10 & 11 & 1 & 7 \\
\hline 2,3,7,8-TCDD & $\mathrm{ng} / \mathrm{kg}$ & 9 & 9 & 8 & 10 & 8 & 9 & 9 & 0 & 1 \\
\hline $2,3,7,8-$ & $\mathrm{ng} / \mathrm{kg}$ & 3 & 2 & 2 & 3 & 2 & 2 & 2 & 1 & 4 \\
\hline
\end{tabular}




\begin{tabular}{|c|c|c|c|c|c|c|c|c|c|c|}
\hline TETRACHLORODIBENZOFUR & & & & & & & & & & \\
\hline OCDD & $\mathrm{ng} / \mathrm{kg}$ & 84340 & 84080 & 75840 & 100420 & 85980 & 79280 & 84738 & 50860 & 22600 \\
\hline OCDF & $\mathrm{ng} / \mathrm{kg}$ & 2034 & 1854 & 1734 & 2112 & 1626 & 1714 & 1794 & 572 & 835 \\
\hline TCDD TEQ & $\mathrm{ng} / \mathrm{kg}$ & 297 & 303 & 267 & 332 & 286 & 266 & 288 & 55 & 57 \\
\hline 1,1'-Biphenyl & $\begin{array}{l}\mathrm{UG} / \\
\mathrm{KG}\end{array}$ & 0 & 0 & 0 & 0 & 0 & 0 & 0 & 0 & 62 \\
\hline 1-METHYLNAPHTHALENE & $\begin{array}{l}\mathrm{UG} / \\
\mathrm{KG} \\
\end{array}$ & 0 & 0 & 0 & 0 & 0 & 0 & 0 & 0 & 0 \\
\hline 2-METHYLNAPHTHALENE & $\begin{array}{l}\mathrm{UG} / \\
\mathrm{KG}\end{array}$ & 0 & 0 & 0 & 0 & 0 & 0 & 0 & 0 & 138 \\
\hline ACENAPHTHENE & $\begin{array}{l}\mathrm{UG} / \\
\mathrm{KG} \\
\end{array}$ & 0 & 0 & 0 & 0 & 0 & 0 & 0 & 16 & 0 \\
\hline ACENAPHTHYLENE & $\mathrm{ug} / \mathrm{kg}$ & 0 & 0 & 8 & 0 & 0 & 0 & 0 & 0 & 151 \\
\hline ANTHRACENE & $\mathrm{ug} / \mathrm{kg}$ & 7 & 0 & 9 & 0 & 0 & 0 & 5 & 22 & 639 \\
\hline AZOBENZENE & $\begin{array}{l}\mathrm{UG} / \\
\mathrm{KG}\end{array}$ & 0 & 0 & 0 & 0 & 0 & 0 & 0 & 0 & 0 \\
\hline BENZO(A)ANTHRACENE & $\mathrm{ug} / \mathrm{kg}$ & 39 & 21 & 20 & 0 & 0 & 19 & 27 & 38 & 1322 \\
\hline BENZO(A)PYRENE & $\mathrm{ug} / \mathrm{kg}$ & 38 & 24 & 48 & 12 & 0 & 38 & 37 & 44 & 4500 \\
\hline BENZO(B)FLUORANTHENE & $\mathrm{ug} / \mathrm{kg}$ & 66 & 55 & 69 & 35 & 0 & 67 & 69 & 54 & 6278 \\
\hline Benzo(e)pyrene & $\mathrm{ug} / \mathrm{kg}$ & 49 & 40 & 61 & 26 & 12 & 47 & 53 & 42 & 4356 \\
\hline BENZO(G,H,I)PERYLENE & $\mathrm{ug} / \mathrm{kg}$ & 27 & 18 & 58 & 34 & 0 & 38 & 35 & 20 & 7922 \\
\hline BENZO(K)FLUORANTHENE & $\mathrm{ug} / \mathrm{kg}$ & 16 & 0 & 7 & 0 & 0 & 6 & 0 & 18 & 1157 \\
\hline bis(2-Ethylhexyl)phthalate & $\mathrm{ug} / \mathrm{kg}$ & 0 & 0 & 0 & 0 & 0 & 0 & 0 & 0 & 0 \\
\hline Butylbenzylphthalate & $\mathrm{ug} / \mathrm{kg}$ & 0 & 0 & 0 & 0 & 0 & 0 & 0 & 0 & 0 \\
\hline Chrysene & $\mathrm{ug} / \mathrm{kg}$ & 68 & 40 & 57 & 0 & 0 & 43 & 53 & 50 & 2256 \\
\hline Di-n-butylphthalate & $\mathrm{ug} / \mathrm{kg}$ & 0 & 0 & 0 & 0 & 0 & 0 & 0 & 0 & 0 \\
\hline DIBENZO(A,H)ANTHRACENE & $\begin{array}{l}\text { UG/ } \\
\text { KG }\end{array}$ & 0 & 0 & 0 & 0 & 0 & 0 & 0 & 6 & 1211 \\
\hline Di-n-octylphthalate & $\mathrm{ug} / \mathrm{kg}$ & 0 & 0 & 0 & 0 & 0 & 0 & 0 & 0 & 0 \\
\hline
\end{tabular}




\begin{tabular}{|c|c|c|c|c|c|c|c|c|c|c|}
\hline FLUORANTHENE & $\mathrm{ug} / \mathrm{kg}$ & 129 & 86 & 144 & 49 & 62 & 102 & 110 & 96 & 2622 \\
\hline FLUORENE & $\begin{array}{l}\mathrm{UG} / \\
\mathrm{KG}\end{array}$ & 0 & 0 & 0 & 0 & 0 & 0 & 0 & 10 & 84 \\
\hline INDENO(1,2,3-CD)PYRENE & $\mathrm{ug} / \mathrm{kg}$ & 17 & 0 & 25 & 0 & 0 & 8 & 6 & 17 & 7611 \\
\hline $\begin{array}{l}\text { METHANAMINE, N-METHYL-N- } \\
\text { NITROSO }\end{array}$ & $\begin{array}{l}\mathrm{UG} / \\
\mathrm{KG}\end{array}$ & 0 & 0 & 0 & 0 & 0 & 0 & 0 & 0 & 111 \\
\hline NAPHTHALENE & $\begin{array}{l}\mathrm{UG} / \\
\mathrm{KG}\end{array}$ & 0 & 0 & 0 & 0 & 0 & 0 & 0 & 0 & 203 \\
\hline PHENANTHRENE & $\mathrm{ug} / \mathrm{kg}$ & 55 & 47 & 92 & 16 & 0 & 61 & 38 & 100 & 2222 \\
\hline PYRENE & $\mathrm{ug} / \mathrm{kg}$ & 114 & 20 & 117 & 42 & 24 & 93 & 94 & 94 & 1678 \\
\hline Aroclor 1016 & $\begin{array}{l}\text { UG/ } \\
\mathrm{KG}\end{array}$ & 0 & 0 & 0 & 0 & 0 & 0 & 0 & 0 & 0 \\
\hline Aroclor 1221 & $\begin{array}{l}\mathrm{UG} / \\
\mathrm{KG}\end{array}$ & 0 & 0 & 0 & 0 & 0 & 0 & 0 & 0 & 0 \\
\hline Aroclor 1232 & $\begin{array}{l}\mathrm{UG} / \\
\mathrm{KG}\end{array}$ & 0 & 0 & 0 & 0 & 0 & 0 & 0 & 0 & 0 \\
\hline Aroclor 1242 & $\begin{array}{l}\mathrm{UG} / \\
\mathrm{KG}\end{array}$ & 0 & 0 & 0 & 0 & 0 & 0 & 0 & 0 & 0 \\
\hline Aroclor 1248 & $\begin{array}{l}\mathrm{UG} / \\
\mathrm{KG}\end{array}$ & 0 & 0 & 0 & 0 & 0 & 0 & 0 & 0 & 0 \\
\hline Aroclor 1254 & $\mathrm{ug} / \mathrm{kg}$ & 132 & 150 & 142 & 160 & 140 & 132 & 645 & 59 & 127 \\
\hline Aroclor 1260 & $\mathrm{ug} / \mathrm{kg}$ & 97 & 108 & 110 & 110 & 103 & 112 & 328 & 37 & 111 \\
\hline Aroclor 1262 & $\begin{array}{l}\mathrm{UG} / \\
\mathrm{KG}\end{array}$ & 0 & 0 & 0 & 0 & 0 & 0 & 0 & 0 & 0 \\
\hline Aroclor 1268 & $\begin{array}{l}\mathrm{UG} / \\
\mathrm{KG}\end{array}$ & 0 & 0 & 0 & 0 & 0 & 0 & 0 & 0 & 0 \\
\hline Aroclor 5432 & $\begin{array}{l}\mathrm{UG} / \\
\mathrm{KG}\end{array}$ & 0 & 0 & 0 & 0 & 0 & 0 & 0 & 0 & 0 \\
\hline Aroclor 5442 & $\begin{array}{l}\mathrm{UG} / \\
\mathrm{KG}\end{array}$ & 0 & 0 & 0 & 0 & 0 & 0 & 0 & 0 & 0 \\
\hline Aroclor 5460 & $\mathrm{ug} / \mathrm{kg}$ & 97 & 191 & 142 & 108 & 93 & 80 & 908 & 0 & 102 \\
\hline
\end{tabular}




\begin{tabular}{|c|c|c|c|c|c|c|c|c|c|c|}
\hline EFH (C12-C14) & $\begin{array}{l}\text { MG/ } \\
\mathrm{KG}\end{array}$ & 0 & 21 & 0 & 0 & 1 & 0 & 1 & 0 & 1 \\
\hline EFH (C15-C20) & $\begin{array}{l}\text { MG/ } \\
\mathrm{KG}\end{array}$ & 0 & 376 & 4 & 5 & 404 & 0 & 2 & 0 & 17 \\
\hline EFH (C21-C30) & $\begin{array}{l}\mathrm{mg} / \mathrm{k} \\
\mathrm{g}\end{array}$ & 94 & 1046 & 79 & 84 & 1414 & 55 & 79 & 49 & 133 \\
\hline EFH (C30-C40) & $\begin{array}{l}\mathrm{mg} / \mathrm{k} \\
\mathrm{g}\end{array}$ & 87 & 166 & 73 & 57 & 130 & 45 & 52 & 50 & 86 \\
\hline $\mathrm{EFH}(\mathrm{C} 8-\mathrm{C} 11)$ & $\begin{array}{l}\text { MG/ } \\
\mathrm{KG}\end{array}$ & 0 & 14 & 0 & 0 & 1 & 0 & 1 & 0 & 1 \\
\hline \multicolumn{11}{|l|}{ Jun/126 days } \\
\hline Chemical & Units & \multicolumn{9}{|c|}{ Mean Concentration } \\
\hline $\begin{array}{l}1,2,3,4,6,7,8- \\
\text { HEPTACHLORODIBENZO-P- } \\
\text { DIOXIN }\end{array}$ & $\mathrm{ng} / \mathrm{kg}$ & 9292 & 9774 & 9186 & 10120 & 9850 & N/A & 9571 & 2956 & 2171 \\
\hline 1,2,3,4,6,7,8-HPCDF & $\mathrm{ng} / \mathrm{kg}$ & 781 & 790 & 789 & 821 & 850 & N/A & 828 & 167 & 252 \\
\hline 1,2,3,4,7,8,9-HPCDF & $\mathrm{ng} / \mathrm{kg}$ & 70 & 70 & 68 & 71 & 72 & N/A & 72 & 12 & 19 \\
\hline $\begin{array}{l}\text { 1,2,3,4,7,8-HEXACHLORODIBENZO- } \\
\text { P-DIOXIN }\end{array}$ & $\mathrm{ng} / \mathrm{kg}$ & 72 & 73 & 69 & 73 & 70 & N/A & 74 & 5 & 16 \\
\hline $1,2,3,4,7,8-\mathrm{HXCDF}$ & $\mathrm{ng} / \mathrm{kg}$ & 21 & 21 & 21 & 22 & 23 & N/A & 22 & 2 & 10 \\
\hline $\begin{array}{l}\text { 1,2,3,6,7,8-HEXACHLORODIBENZO- } \\
\text { P-DIOXIN }\end{array}$ & $\mathrm{ng} / \mathrm{kg}$ & 411 & 427 & 402 & 406 & 427 & N/A & 432 & 60 & 82 \\
\hline $1,2,3,6,7,8-\mathrm{HXCDF}$ & $\mathrm{ng} / \mathrm{kg}$ & 23 & 23 & 23 & 23 & 25 & N/A & 25 & 2 & 8 \\
\hline $\begin{array}{l}\text { 1,2,3,7,8,9-HEXACHLORODIBENZO- } \\
\text { P-DIOXIN }\end{array}$ & $\mathrm{ng} / \mathrm{kg}$ & 169 & 172 & 158 & 172 & 167 & N/A & 176 & 13 & 35 \\
\hline $1,2,3,7,8,9-\mathrm{HXCDF}$ & $\mathrm{ng} / \mathrm{kg}$ & 5 & 7 & 3 & 4 & 4 & N/A & 2 & 0 & 0 \\
\hline $\begin{array}{l}1,2,3,7,8- \\
\text { PENTACHLORODIBENZOFURAN }\end{array}$ & $\mathrm{ng} / \mathrm{kg}$ & 7 & 7 & 7 & 7 & 7 & N/A & 7 & 0 & 3 \\
\hline $\begin{array}{l}\text { 1,2,3,7,8-PENTACHLORODIBENZO- } \\
\text { P-DIOXIN }\end{array}$ & $\mathrm{ng} / \mathrm{kg}$ & 49 & 50 & 46 & 48 & 48 & N/A & 52 & 2 & 8 \\
\hline $2,3,4,6,7,8-\mathrm{HXCDF}$ & $\mathrm{ng} / \mathrm{kg}$ & 42 & 41 & 40 & 42 & 42 & N/A & 42 & 4 & 13 \\
\hline
\end{tabular}




\begin{tabular}{|c|c|c|c|c|c|c|c|c|c|c|}
\hline 2,3,4,7,8-PECDF & $\mathrm{ng} / \mathrm{kg}$ & 8 & 10 & 9 & 9 & 9 & N/A & 9 & 1 & 7 \\
\hline 2,3,7,8-TCDD & $\mathrm{ng} / \mathrm{kg}$ & 9 & 9 & 8 & 8 & 9 & N/A & 8 & 0 & 1 \\
\hline $\begin{array}{l}2,3,7,8- \\
\text { TETRACHLORODIBENZOFURAN }\end{array}$ & $\mathrm{ng} / \mathrm{kg}$ & 2 & 2 & 2 & 2 & 2 & N/A & 2 & 1 & 4 \\
\hline OCDD & $\mathrm{ng} / \mathrm{kg}$ & 66580 & 71080 & 76000 & 76500 & 74900 & N/A & 68871 & 50720 & 23129 \\
\hline $\mathrm{OCDF}$ & $\mathrm{ng} / \mathrm{kg}$ & 1688 & 1672 & 13584 & 1786 & 1864 & N/A & 1804 & 580 & 831 \\
\hline TCDD TEQ & $\mathrm{ng} / \mathrm{kg}$ & 247 & 264 & 534 & 266 & 262 & N/A & 264 & 56 & 56 \\
\hline 1,1'-Biphenyl & $\begin{array}{l}\mathrm{UG} / \\
\mathrm{KG}\end{array}$ & 0 & 0 & 0 & 0 & 0 & N/A & 0 & 0 & 48 \\
\hline 1-METHYLNAPHTHALENE & $\begin{array}{l}\mathrm{UG} / \\
\mathrm{KG}\end{array}$ & 0 & 0 & 0 & 0 & 0 & N/A & 0 & 0 & 67 \\
\hline 2-METHYLNAPHTHALENE & $\begin{array}{l}\mathrm{UG} / \\
\mathrm{KG} \\
\end{array}$ & 0 & 0 & 0 & 0 & 0 & N/A & 0 & 0 & 103 \\
\hline ACENAPHTHENE & $\begin{array}{l}\mathrm{UG} / \\
\mathrm{KG} \\
\end{array}$ & 9 & 0 & 0 & 0 & 0 & N/A & 0 & 0 & 12 \\
\hline ACENAPHTHYLENE & $\mathrm{ug} / \mathrm{kg}$ & 0 & 3 & 0 & 0 & 0 & N/A & 0 & 0 & 129 \\
\hline ANTHRACENE & $\mathrm{ug} / \mathrm{kg}$ & 16 & 6 & 3 & 7 & 0 & N/A & 0 & 0 & 566 \\
\hline AZOBENZENE & $\begin{array}{l}\mathrm{UG} / \\
\mathrm{KG}\end{array}$ & 0 & 0 & 0 & 0 & 0 & N/A & 0 & & 0 \\
\hline BENZO(A)ANTHRACENE & $\mathrm{ug} / \mathrm{kg}$ & 46 & 27 & 24 & 8 & 30 & N/A & 23 & 16 & 1171 \\
\hline BENZO(A)PYRENE & $\mathrm{ug} / \mathrm{kg}$ & 49 & 29 & 36 & 26 & 36 & N/A & 33 & 6 & 3757 \\
\hline BENZO(B)FLUORANTHENE & $\mathrm{ug} / \mathrm{kg}$ & 75 & 59 & 58 & 45 & 60 & N/A & 58 & 17 & 5043 \\
\hline Benzo(e)pyrene & $\mathrm{ug} / \mathrm{kg}$ & 49 & 34 & 37 & 35 & 44 & N/A & 40 & 33 & 3514 \\
\hline BENZO $(\mathrm{G}, \mathrm{H}, \mathrm{I})$ PERYLENE & $\mathrm{ug} / \mathrm{kg}$ & 36 & 29 & 36 & 33 & 28 & N/A & 35 & 15 & 7057 \\
\hline BENZO(K)FLUORANTHENE & $\mathrm{ug} / \mathrm{kg}$ & 13 & 13 & 11 & 5 & 15 & N/A & 10 & 3 & 1060 \\
\hline bis(2-Ethylhexyl)phthalate & $\mathrm{ug} / \mathrm{kg}$ & 0 & 0 & 0 & 0 & 0 & N/A & 0 & 0 & 0 \\
\hline Butylbenzylphthalate & $\mathrm{ug} / \mathrm{kg}$ & 0 & 0 & 0 & 0 & 0 & N/A & 0 & 0 & 0 \\
\hline Chrysene & $\mathrm{ug} / \mathrm{kg}$ & 68 & 60 & 46 & 36 & 55 & N/A & 45 & 11 & 1814 \\
\hline Di-n-butylphthalate & $\mathrm{ug} / \mathrm{kg}$ & 0 & 0 & 0 & 0 & 0 & N/A & 0 & 0 & 0 \\
\hline
\end{tabular}




\begin{tabular}{|c|c|c|c|c|c|c|c|c|c|c|}
\hline DIBENZO(A,H)ANTHRACENE & $\begin{array}{l}\mathrm{UG} / \\
\mathrm{KG}\end{array}$ & 6 & 0 & 3 & 0 & 0 & N/A & 0 & 0 & 1229 \\
\hline Di-n-octylphthalate & $\mathrm{ug} / \mathrm{kg}$ & 0 & 0 & 0 & 0 & 0 & $\mathrm{~N} / \mathrm{A}$ & 0 & 0 & 0 \\
\hline FLUORANTHENE & $\mathrm{ug} / \mathrm{kg}$ & 129 & 116 & 93 & 69 & 87 & N/A & 76 & 14 & 2186 \\
\hline FLUORENE & $\begin{array}{l}\mathrm{UG} / \\
\mathrm{KG}\end{array}$ & 6 & 0 & 0 & 0 & 0 & N/A & 0 & 0 & 22 \\
\hline INDENO(1,2,3-CD)PYRENE & $\mathrm{ug} / \mathrm{kg}$ & 16 & 23 & 24 & 20 & 19 & N/A & 23 & 5 & 7057 \\
\hline $\begin{array}{l}\text { METHANAMINE, N-METHYL-N- } \\
\text { NITROSO }\end{array}$ & $\begin{array}{l}\mathrm{UG} / \\
\mathrm{KG}\end{array}$ & 0 & 0 & 0 & 0 & 0 & N/A & 0 & 0 & 0 \\
\hline NAPHTHALENE & $\begin{array}{l}\mathrm{UG} / \\
\mathrm{KG}\end{array}$ & 0 & 0 & 0 & 0 & 0 & N/A & 0 & & 177 \\
\hline PHENANTHRENE & $\mathrm{ug} / \mathrm{kg}$ & 91 & 55 & 38 & 38 & 39 & N/A & 31 & 7 & 1900 \\
\hline PYRENE & $\mathrm{ug} / \mathrm{kg}$ & 117 & 100 & 79 & 62 & 73 & $\mathrm{~N} / \mathrm{A}$ & 68 & 11 & 1414 \\
\hline Aroclor 1016 & $\begin{array}{l}\mathrm{UG} / \\
\mathrm{KG}\end{array}$ & 0 & 0 & 0 & 0 & 0 & N/A & 0 & 0 & 0 \\
\hline Aroclor 1221 & $\begin{array}{l}\mathrm{UG} / \\
\mathrm{KG}\end{array}$ & 0 & 0 & 0 & 0 & 0 & N/A & 0 & 0 & 0 \\
\hline Aroclor 1232 & $\begin{array}{l}\mathrm{UG} / \\
\mathrm{KG}\end{array}$ & 0 & 0 & 0 & 0 & 0 & N/A & 0 & 0 & 0 \\
\hline Aroclor 1242 & $\begin{array}{l}\mathrm{UG} / \\
\mathrm{KG}\end{array}$ & 0 & 0 & 0 & 0 & 0 & N/A & 0 & 0 & 0 \\
\hline Aroclor 1248 & $\begin{array}{l}\mathrm{UG} / \\
\mathrm{KG}\end{array}$ & 0 & 0 & 0 & 0 & 0 & N/A & 0 & 0 & 0 \\
\hline Aroclor 1254 & $\mathrm{ug} / \mathrm{kg}$ & 71 & 73 & 74 & 58 & 85 & N/A & 69 & 59 & 137 \\
\hline Aroclor 1260 & $\mathrm{ug} / \mathrm{kg}$ & 128 & 116 & 120 & 118 & 126 & N/A & 121 & 38 & 143 \\
\hline Aroclor 1262 & $\begin{array}{l}\mathrm{UG} / \\
\mathrm{KG}\end{array}$ & 0 & 0 & 0 & 0 & 0 & N/A & 0 & 0 & 0 \\
\hline Aroclor 1268 & $\begin{array}{l}\mathrm{UG} / \\
\mathrm{KG} \\
\end{array}$ & 0 & 0 & 0 & 0 & 0 & N/A & 0 & 0 & 0 \\
\hline Aroclor 5432 & $\begin{array}{l}\mathrm{UG} / \\
\mathrm{KG}\end{array}$ & 0 & 0 & 0 & 0 & 0 & N/A & 0 & 0 & 0 \\
\hline
\end{tabular}




\begin{tabular}{|c|c|c|c|c|c|c|c|c|c|c|}
\hline Aroclor 5442 & $\begin{array}{l}\mathrm{UG} / \\
\mathrm{KG}\end{array}$ & 0 & 0 & 0 & 0 & 0 & N/A & 0 & 0 & 0 \\
\hline Aroclor 5460 & $\mathrm{ug} / \mathrm{kg}$ & 87 & 89 & 92 & 58 & 81 & N/A & 70 & 0 & 112 \\
\hline EFH (C12-C14) & $\begin{array}{l}\mathrm{MG/} \\
\mathrm{KG}\end{array}$ & 0 & 0 & 0 & 0 & 0 & N/A & 0 & 0 & 1 \\
\hline EFH (C15-C20) & $\begin{array}{l}\mathrm{MG} / \\
\mathrm{KG}\end{array}$ & 0 & 5 & 2 & 1 & 7 & N/A & 0 & 0 & 21 \\
\hline EFH (C21-C30) & $\mathrm{mg} / \mathrm{k}$ & 40 & 55 & 67 & 58 & 71 & N/A & 49 & 46 & 137 \\
\hline EFH (C30-C40) & $\begin{array}{l}\mathrm{mg} / \mathrm{k} \\
\mathrm{g}\end{array}$ & 109 & 109 & 68 & 54 & 78 & N/A & 42 & 59 & 73 \\
\hline EFH (C8-C11) & $\begin{array}{l}\mathrm{MG} / \\
\mathrm{KG}\end{array}$ & 0 & 0 & 0 & 0 & 0 & N/A & 0 & 0 & 0 \\
\hline \multicolumn{11}{|l|}{ Oct/244 days } \\
\hline Chemical & $\begin{array}{l}\text { Unit } \\
\text { of } \\
\text { Meas } \\
\text { ure }\end{array}$ & \multicolumn{9}{|c|}{ Mean Concentration } \\
\hline $\begin{array}{l}1,2,3,4,6,7,8- \\
\text { HEPTACHLORODIBENZO-P- } \\
\text { DIOXIN }\end{array}$ & $\mathrm{ng} / \mathrm{kg}$ & 13110 & 9340 & 10086 & 10182 & 12070 & 11180 & 11160 & 3288 & 2388 \\
\hline $1,2,3,4,6,7,8-\mathrm{HPCDF}$ & $\mathrm{ng} / \mathrm{kg}$ & 1269 & 852 & 879 & 878 & 864 & 926 & 893 & 163 & 268 \\
\hline 1,2,3,4,7,8,9-HPCDF & $\mathrm{ng} / \mathrm{kg}$ & 100 & 73 & 73 & 77 & 79 & 83 & 81 & 11 & 20 \\
\hline $\begin{array}{l}\text { 1,2,3,4,7,8-HEXACHLORODIBENZO- } \\
\text { P-DIOXIN }\end{array}$ & $\mathrm{ng} / \mathrm{kg}$ & 90 & 77 & 75 & 81 & 83 & 95 & 90 & 6 & 18 \\
\hline $1,2,3,4,7,8-\mathrm{HXCDF}$ & $\mathrm{ng} / \mathrm{kg}$ & 28 & 22 & 24 & 23 & 23 & 25 & 81 & 2 & 12 \\
\hline $\begin{array}{l}\text { 1,2,3,6,7,8-HEXACHLORODIBENZO- } \\
\text { P-DIOXIN }\end{array}$ & $\mathrm{ng} / \mathrm{kg}$ & 593 & 446 & 461 & 459 & 499 & 489 & 490 & 70 & 90 \\
\hline $1,2,3,6,7,8-\mathrm{HXCDF}$ & $\mathrm{ng} / \mathrm{kg}$ & 31 & 24 & 26 & 25 & 26 & 27 & 27 & 2 & 9 \\
\hline $\begin{array}{l}1,2,3,7,8,9-H E X A C H L O R O D I B E N Z O- \\
\text { P-DIOXIN }\end{array}$ & $\mathrm{ng} / \mathrm{kg}$ & 214 & 181 & 178 & 182 & 197 & 209 & 197 & 15 & 38 \\
\hline $1,2,3,7,8,9-\mathrm{HXCDF}$ & $\mathrm{ng} / \mathrm{kg}$ & 6 & 0 & 0 & & 0 & 0 & 0 & 2 & 0 \\
\hline
\end{tabular}




\begin{tabular}{|c|c|c|c|c|c|c|c|c|c|c|}
\hline $\begin{array}{l}1,2,3,7,8- \\
\text { PENTACHLORODIBENZOFURAN }\end{array}$ & $\mathrm{ng} / \mathrm{kg}$ & 10 & 8 & 9 & 8 & 7 & 8 & 7 & 1 & 4 \\
\hline $\begin{array}{l}\text { 1,2,3,7,8-PENTACHLORODIBENZO- } \\
\text { P-DIOXIN }\end{array}$ & $\mathrm{ng} / \mathrm{kg}$ & 59 & 51 & 51 & 53 & 57 & 62 & 60 & 2 & 9 \\
\hline $2,3,4,6,7,8-\mathrm{HXCDF}$ & $\mathrm{ng} / \mathrm{kg}$ & 57 & 44 & 45 & 46 & 47 & 51 & 50 & 3 & 16 \\
\hline 2,3,4,7,8-PECDF & $\mathrm{ng} / \mathrm{kg}$ & 12 & 9 & 10 & 10 & 10 & 11 & 11 & 1 & 8 \\
\hline $2,3,7,8-\mathrm{TCDD}$ & $\mathrm{ng} / \mathrm{kg}$ & 10 & 10 & 9 & 10 & 11 & 11 & 10 & 0 & 1 \\
\hline $\begin{array}{l}2,3,7,8- \\
\text { TETRACHLORODIBENZOFURAN }\end{array}$ & $\mathrm{ng} / \mathrm{kg}$ & 3 & 3 & 3 & 3 & 3 & 3 & 3 & 1 & 4 \\
\hline OCDD & $\mathrm{ng} / \mathrm{kg}$ & 108200 & 75060 & 79860 & 71480 & 82020 & 83840 & 81260 & 51200 & 26680 \\
\hline OCDF & $\mathrm{ng} / \mathrm{kg}$ & 2918 & 1848 & 1936 & 1898 & 1860 & 2016 & 1894 & 575 & 887 \\
\hline TCDD TEQ & $\mathrm{ng} / \mathrm{kg}$ & 469 & 269 & 276 & 282 & 314 & 314 & 309 & 62 & 67 \\
\hline 1,1'-Biphenyl & UG/ & 0 & 0 & 0 & 0 & 0 & 0 & 0 & 0 & 0 \\
\hline 1-METHYLNAPHTHALENE & $\begin{array}{l}\mathrm{UG} / \\
\mathrm{KG}\end{array}$ & 4 & 2 & 3 & 2 & 5 & 3 & 4 & 0 & 600 \\
\hline 2-METHYLNAPHTHALENE & $\begin{array}{l}\mathrm{UG} / \\
\mathrm{KG}\end{array}$ & 9 & 10 & 8 & 9 & 9 & 9 & 10 & 0 & 782 \\
\hline ACENAPHTHENE & $\begin{array}{l}\mathrm{UG} / \\
\mathrm{KG}\end{array}$ & 5 & 0 & 5 & 7 & 34 & 3 & 2 & 0 & 24 \\
\hline ACENAPHTHYLENE & $\mathrm{ug} / \mathrm{kg}$ & 3 & 1 & 7 & 0 & 7 & 2 & 2 & 0 & 148 \\
\hline ANTHRACENE & $\mathrm{ug} / \mathrm{kg}$ & 9 & 16 & 11 & 12 & 48 & 13 & 9 & 0 & 846 \\
\hline AZOBENZENE & $\begin{array}{l}\mathrm{UG} / \\
\mathrm{KG}\end{array}$ & 0 & 0 & 0 & 0 & 0 & 0 & 0 & 0 & 0 \\
\hline BENZO(A)ANTHRACENE & $\mathrm{ug} / \mathrm{kg}$ & 21 & 126 & 38 & 42 & 96 & 54 & 29 & 3 & 1780 \\
\hline BENZO(A)PYRENE & $\mathrm{ug} / \mathrm{kg}$ & 19 & 87 & 34 & 40 & 82 & 49 & 27 & 0 & 3620 \\
\hline BENZO(B)FLUORANTHENE & $\mathrm{ug} / \mathrm{kg}$ & 47 & 142 & 66 & 70 & 127 & 86 & 58 & 6 & 5380 \\
\hline Benzo(e)pyrene & $\mathrm{ug} / \mathrm{kg}$ & 10 & 56 & 32 & 24 & 56 & 36 & 16 & 0 & 3320 \\
\hline BENZO(G,H,I)PERYLENE & $\mathrm{ug} / \mathrm{kg}$ & 12 & 42 & 19 & 20 & 51 & 33 & 17 & 6 & 2640 \\
\hline BENZO(K)FLUORANTHENE & $\mathrm{ug} / \mathrm{kg}$ & 21 & 57 & 25 & 28 & 58 & 32 & 24 & 0 & 1900 \\
\hline
\end{tabular}




\begin{tabular}{|c|c|c|c|c|c|c|c|c|c|c|}
\hline bis(2-Ethylhexyl)phthalate & $\mathrm{ug} / \mathrm{kg}$ & 92 & 79 & 73 & 51 & 137 & 56 & 75 & 20 & 430 \\
\hline Butylbenzylphthalate & $\mathrm{ug} / \mathrm{kg}$ & 0 & 0 & 15 & 0 & 0 & 15 & 0 & 0 & 0 \\
\hline Chrysene & $\mathrm{ug} / \mathrm{kg}$ & 59 & 165 & 83 & 72 & 144 & 97 & 73 & 15 & 2780 \\
\hline Di-n-butylphthalate & $\mathrm{ug} / \mathrm{kg}$ & 18 & 34 & 0 & 30 & 0 & 0 & 0 & 0 & 0 \\
\hline DIBENZO(A,H)ANTHRACENE & $\begin{array}{l}\mathrm{UG} / \\
\mathrm{KG}\end{array}$ & 0 & 9 & 5 & 4 & 12 & 10 & 0 & 0 & 672 \\
\hline Di-n-octylphthalate & $\mathrm{ug} / \mathrm{kg}$ & 0 & 0 & 0 & 0 & 0 & 0 & 0 & 0 & 270 \\
\hline FLUORANTHENE & $\mathrm{ug} / \mathrm{kg}$ & 143 & 248 & 132 & 106 & 280 & 138 & 138 & 0 & 4540 \\
\hline FLUORENE & $\begin{array}{l}\mathrm{UG} / \\
\mathrm{KG}\end{array}$ & 5 & 0 & 4 & 5 & 24 & 2 & 2 & 0 & 39 \\
\hline INDENO(1,2,3-CD)PYRENE & $\mathrm{ug} / \mathrm{kg}$ & 6 & 37 & 14 & 17 & 43 & 27 & 13 & 0 & 3500 \\
\hline $\begin{array}{l}\text { METHANAMINE, N-METHYL-N- } \\
\text { NITROSO }\end{array}$ & $\begin{array}{l}\mathrm{UG} / \\
\mathrm{KG}\end{array}$ & 0 & 0 & 0 & 0 & 0 & 0 & 0 & 0 & 0 \\
\hline NAPHTHALENE & $\begin{array}{l}\mathrm{UG} / \\
\mathrm{KG} \\
\end{array}$ & 4 & 4 & 4 & 7 & 43 & 3 & 2 & 0 & 614 \\
\hline PHENANTHRENE & $\mathrm{ug} / \mathrm{kg}$ & 86 & 1848 & 75 & 73 & 229 & 77 & 74 & 0 & 4600 \\
\hline PYRENE & $\mathrm{ug} / \mathrm{kg}$ & 100 & 216 & 104 & 89 & 222 & 103 & 102 & 0 & 2100 \\
\hline Aroclor 1016 & $\begin{array}{l}\mathrm{UG} / \\
\mathrm{KG}\end{array}$ & 0 & 0 & 0 & 4 & 0 & 0 & 0 & 0 & 0 \\
\hline Aroclor 1221 & $\begin{array}{l}\mathrm{UG} / \\
\mathrm{KG}\end{array}$ & 0 & 0 & 0 & 0 & 0 & 0 & 0 & 0 & 0 \\
\hline Aroclor 1232 & $\begin{array}{l}\mathrm{UG} / \\
\mathrm{KG} \\
\end{array}$ & 0 & 0 & 0 & 0 & 0 & 0 & 0 & 0 & 0 \\
\hline Aroclor 1242 & $\begin{array}{l}\mathrm{UG} / \\
\mathrm{KG}\end{array}$ & 0 & 0 & 0 & 0 & 0 & 0 & 0 & 0 & 0 \\
\hline Aroclor 1248 & $\begin{array}{l}\mathrm{UG} / \\
\mathrm{KG} \\
\end{array}$ & 0 & 0 & 0 & 0 & 0 & 0 & 0 & 0 & 0 \\
\hline Aroclor 1254 & $\mathrm{ug} / \mathrm{kg}$ & 65 & 70 & 63 & 77 & 77 & 70 & 78 & 75 & 29 \\
\hline Aroclor 1260 & $\mathrm{ug} / \mathrm{kg}$ & 77 & 66 & 65 & 78 & 69 & 70 & 80 & 95 & 22 \\
\hline Aroclor 1262 & $\begin{array}{l}\mathrm{UG} / \\
\mathrm{KG}\end{array}$ & 0 & 0 & 0 & 0 & 0 & 0 & 0 & 0 & 0 \\
\hline
\end{tabular}




\begin{tabular}{|c|c|c|c|c|c|c|c|c|c|c|}
\hline Aroclor 1268 & $\begin{array}{l}\text { UG/ } \\
\text { KG }\end{array}$ & 0 & 0 & 0 & 0 & 0 & 0 & 0 & 0 & 0 \\
\hline Aroclor 5432 & $\begin{array}{l}\mathrm{UG} / \\
\mathrm{KG}\end{array}$ & 0 & 0 & 0 & 0 & 0 & 0 & 0 & 0 & 0 \\
\hline Aroclor 5442 & $\begin{array}{l}\mathrm{UG} / \\
\mathrm{KG}\end{array}$ & 0 & 0 & 0 & 0 & 0 & 0 & 0 & 0 & 0 \\
\hline Aroclor 5460 & $\mathrm{ug} / \mathrm{kg}$ & 73 & 61 & 59 & 81 & 71 & 77 & 106 & 91 & 0 \\
\hline EFH (C12-C14) & $\begin{array}{l}\mathrm{MG} / \\
\mathrm{KG}\end{array}$ & 0 & & 0 & 0 & & 0 & 0 & 0 & 0 \\
\hline $\mathrm{EFH}(\mathrm{C} 15-\mathrm{C} 20)$ & $\begin{array}{l}\mathrm{MG} / \\
\mathrm{KG}\end{array}$ & 3 & & 10 & 19 & & 28 & 0 & 0 & 140 \\
\hline EFH (C21-C30) & $\begin{array}{l}\mathrm{mg} / \mathrm{k} \\
\mathrm{g}\end{array}$ & 108 & & 132 & 164 & & 174 & 128 & 144 & 560 \\
\hline EFH (C30-C40) & $\begin{array}{l}\mathrm{mg} / \mathrm{k} \\
\mathrm{g}\end{array}$ & 284 & & 360 & 372 & & 420 & 372 & 414 & 888 \\
\hline $\mathrm{EFH}(\mathrm{C} 8-\mathrm{C} 11)$ & $\begin{array}{l}\mathrm{MG} / \\
\mathrm{KG}\end{array}$ & 0 & & 0 & 0 & & 0 & 0 & 0 & 0 \\
\hline \multicolumn{11}{|l|}{ Feb/0 days } \\
\hline Chemical & $\begin{array}{l}\text { Unit } \\
\text { of } \\
\text { Meas } \\
\text { ure } \\
\end{array}$ & $\begin{array}{l}\text { Standar } \\
\mathrm{d} \\
\text { Deviati } \\
\text { on }\end{array}$ & & & & & & & & \\
\hline $\begin{array}{l}1,2,3,4,6,7,8- \\
\text { HEPTACHLORODIBENZO-P- } \\
\text { DIOXIN }\end{array}$ & $\mathrm{ng} / \mathrm{kg}$ & 1377 & 1422 & 1509 & 5018 & 2227 & 818 & 797 & 312 & 73 \\
\hline $1,2,3,4,6,7,8-\mathrm{HPCDF}$ & $\mathrm{ng} / \mathrm{kg}$ & 189 & 65 & 37 & 589 & 376 & 18 & 47 & 36 & 13 \\
\hline 1,2,3,4,7,8,9-HPCDF & $\mathrm{ng} / \mathrm{kg}$ & 14 & 5 & 5 & 36 & 5 & 2 & 5 & 1 & 1 \\
\hline $\begin{array}{l}\text { 1,2,3,4,7,8-HEXACHLORODIBENZO- } \\
\text { P-DIOXIN }\end{array}$ & $\mathrm{ng} / \mathrm{kg}$ & 6 & 10 & 4 & 35 & 9 & 3 & 7 & 1 & 0 \\
\hline $1,2,3,4,7,8-\mathrm{HXCDF}$ & $\mathrm{ng} / \mathrm{kg}$ & 3 & 2 & 2 & 12 & 6 & 1 & 2 & 0 & 0 \\
\hline $\begin{array}{l}\text { 1,2,3,6,7,8-HEXACHLORODIBENZO- } \\
\text { P-DIOXIN }\end{array}$ & $\mathrm{ng} / \mathrm{kg}$ & 54 & 52 & 19 & 219 & 56 & 15 & 27 & 6 & 3 \\
\hline
\end{tabular}




\begin{tabular}{|c|c|c|c|c|c|c|c|c|c|c|}
\hline $1,2,3,6,7,8-\mathrm{HXCDF}$ & $\mathrm{ng} / \mathrm{kg}$ & 8 & 3 & 2 & 50 & 40 & 1 & 3 & 2 & 1 \\
\hline $\begin{array}{l}\text { 1,2,3,7,8,9-HEXACHLORODIBENZO- } \\
\text { P-DIOXIN }\end{array}$ & $\mathrm{ng} / \mathrm{kg}$ & 12 & 24 & 7 & 83 & 20 & 2 & 13 & 2 & 1 \\
\hline $1,2,3,7,8,9-\mathrm{HXCDF}$ & $\mathrm{ng} / \mathrm{kg}$ & 1 & 1 & 1 & 3 & 3 & 3 & 3 & 1 & 2 \\
\hline $\begin{array}{l}1,2,3,7,8- \\
\text { PENTACHLORODIBENZOFURAN }\end{array}$ & $\mathrm{ng} / \mathrm{kg}$ & 1 & 0 & 1 & 4 & 2 & 1 & 1 & 0 & 0 \\
\hline $\begin{array}{l}\text { 1,2,3,7,8-PENTACHLORODIBENZO- } \\
\text { P-DIOXIN }\end{array}$ & $\mathrm{ng} / \mathrm{kg}$ & 2 & 2 & 2 & 26 & 5 & 2 & 4 & 0 & 0 \\
\hline $2,3,4,6,7,8-\mathrm{HXCDF}$ & $\mathrm{ng} / \mathrm{kg}$ & 6 & 3 & 2 & 21 & 2 & 1 & 4 & 0 & 0 \\
\hline 2,3,4,7,8-PECDF & $\mathrm{ng} / \mathrm{kg}$ & 0 & 1 & 0 & 5 & 1 & 1 & 1 & 0 & 0 \\
\hline 2,3,7,8-TCDD & $\mathrm{ng} / \mathrm{kg}$ & 0 & 0 & 1 & 5 & 1 & 0 & 0 & 0 & 0 \\
\hline $\begin{array}{l}2,3,7,8- \\
\text { TETRACHLORODIBENZOFURAN }\end{array}$ & $\mathrm{ng} / \mathrm{kg}$ & 0 & 0 & 0 & 1 & 0 & 0 & 0 & 0 & 0 \\
\hline OCDD & $\mathrm{ng} / \mathrm{kg}$ & 9825 & 5465 & 5226 & 44883 & 11854 & 17348 & 6611 & 7244 & 1384 \\
\hline OCDF & $\mathrm{ng} / \mathrm{kg}$ & 428 & 104 & 119 & 838 & 133 & 24 & 92 & 56 & 53 \\
\hline TCDD TEQ & $\mathrm{ng} / \mathrm{kg}$ & 28 & 27 & 18 & 137 & 33 & 18 & 13 & 2 & 7 \\
\hline 1,1'-Biphenyl & $\begin{array}{ll}\mathrm{UG} / \\
\mathrm{KG}\end{array}$ & 0 & 0 & 0 & 0 & 0 & 0 & 0 & 0 & 4 \\
\hline 1-METHYLNAPHTHALENE & $\begin{array}{l}\mathrm{UG} / \\
\mathrm{KG}\end{array}$ & 0 & 0 & 0 & 0 & 0 & 0 & 0 & 0 & 0 \\
\hline 2-METHYLNAPHTHALENE & $\begin{array}{l}\mathrm{UG} / \\
\mathrm{KG} \\
\end{array}$ & 0 & 0 & 0 & 0 & 0 & 0 & 0 & 0 & 22 \\
\hline ACENAPHTHENE & $\begin{array}{l}\mathrm{UG} / \\
\mathrm{KG} \\
\end{array}$ & 0 & 0 & 0 & 0 & 0 & 0 & 0 & 36 & 0 \\
\hline ACENAPHTHYLENE & $\mathrm{ug} / \mathrm{kg}$ & 0 & 0 & 18 & 0 & 0 & 0 & 0 & 0 & 9 \\
\hline ANTHRACENE & $\mathrm{ug} / \mathrm{kg}$ & 10 & 0 & 13 & 0 & 0 & 0 & 14 & 49 & 48 \\
\hline AZOBENZENE & $\begin{array}{l}\mathrm{UG} / \\
\mathrm{KG} \\
\end{array}$ & 0 & 0 & 0 & 0 & 0 & 0 & 0 & 0 & 0 \\
\hline BENZO(A)ANTHRACENE & $\mathrm{ug} / \mathrm{kg}$ & 12 & 28 & 19 & 0 & 0 & 29 & 25 & 85 & 120 \\
\hline BENZO(A)PYRENE & $\mathrm{ug} / \mathrm{kg}$ & 11 & 24 & 19 & 17 & 0 & 29 & 27 & 98 & 255 \\
\hline
\end{tabular}




\begin{tabular}{|c|c|c|c|c|c|c|c|c|c|c|}
\hline BENZO(B)FLUORANTHENE & $\mathrm{ug} / \mathrm{kg}$ & 22 & 22 & 21 & 4 & 0 & 31 & 27 & 121 & 507 \\
\hline Benzo(e)pyrene & $\mathrm{ug} / \mathrm{kg}$ & 10 & 12 & 35 & 15 & 28 & 14 & 17 & 57 & 251 \\
\hline BENZO(G,H,I)PERYLENE & $\mathrm{ug} / \mathrm{kg}$ & 4 & 17 & 31 & 4 & 0 & 10 & 17 & 44 & 1190 \\
\hline BENZO(K)FLUORANTHENE & $\mathrm{ug} / \mathrm{kg}$ & 5 & 0 & 10 & 0 & 0 & 13 & 0 & 39 & 138 \\
\hline bis(2-Ethylhexyl)phthalate & $\mathrm{ug} / \mathrm{kg}$ & 0 & 0 & 0 & 0 & 0 & 0 & 0 & 0 & 0 \\
\hline Butylbenzylphthalate & $\mathrm{ug} / \mathrm{kg}$ & 0 & 0 & 0 & 0 & 0 & 0 & 0 & 0 & 0 \\
\hline Chrysene & $\mathrm{ug} / \mathrm{kg}$ & 33 & 15 & 38 & 0 & 0 & 35 & 34 & 112 & 321 \\
\hline Di-n-butylphthalate & $\mathrm{ug} / \mathrm{kg}$ & 0 & 0 & 0 & 0 & 0 & 0 & 0 & 0 & 0 \\
\hline DIBENZO(A,H)ANTHRACENE & $\mathrm{ug} / \mathrm{kg}$ & 0 & 0 & 0 & 0 & 0 & 0 & 0 & 14 & 154 \\
\hline Di-n-octylphthalate & $\mathrm{ug} / \mathrm{kg}$ & 0 & 0 & 0 & 0 & 0 & 0 & 0 & 0 & 0 \\
\hline FLUORANTHENE & $\mathrm{ug} / \mathrm{kg}$ & 60 & 30 & 99 & 10 & 4 & 67 & 88 & 215 & 156 \\
\hline FLUORENE & $\mathrm{ug} / \mathrm{kg}$ & 0 & 0 & 0 & 0 & 0 & 0 & 0 & 21 & 41 \\
\hline INDENO(1,2,3-CD)PYRENE & $\mathrm{ug} / \mathrm{kg}$ & 5 & 0 & 16 & 0 & 0 & 18 & 16 & 38 & 918 \\
\hline $\begin{array}{l}\text { METHANAMINE, N-METHYL-N- } \\
\text { NITROSO }\end{array}$ & $\mathrm{ug} / \mathrm{kg}$ & 0 & 0 & 0 & 0 & 0 & 0 & 0 & 0 & 3 \\
\hline NAPHTHALENE & $\mathrm{ug} / \mathrm{kg}$ & 0 & 0 & 0 & 0 & 0 & 0 & 0 & 0 & 19 \\
\hline PHENANTHRENE & $\mathrm{ug} / \mathrm{kg}$ & 34 & 23 & 106 & 22 & 0 & 61 & 62 & 224 & 199 \\
\hline PYRENE & $\mathrm{ug} / \mathrm{kg}$ & 55 & 44 & 60 & 8 & 33 & 66 & 73 & 210 & 97 \\
\hline Aroclor 1016 & $\begin{array}{l}\text { UG/ } \\
\mathrm{KG}\end{array}$ & 0 & 0 & 0 & 0 & 0 & 0 & 0 & 0 & 0 \\
\hline Aroclor 1221 & $\begin{array}{l}\mathrm{UG} / \\
\mathrm{KG}\end{array}$ & 0 & 0 & 0 & 0 & 0 & 0 & 0 & 0 & 0 \\
\hline Aroclor 1232 & $\begin{array}{l}\mathrm{UG} / \\
\mathrm{KG}\end{array}$ & 0 & 0 & 0 & 0 & 0 & 0 & 0 & 0 & 0 \\
\hline Aroclor 1242 & $\begin{array}{l}\mathrm{UG} / \\
\mathrm{KG}\end{array}$ & 0 & 0 & 0 & 0 & 0 & 0 & 0 & 0 & 0 \\
\hline Aroclor 1248 & $\begin{array}{l}\mathrm{UG} / \\
\mathrm{KG}\end{array}$ & 0 & 0 & 0 & 0 & 0 & 0 & 0 & 0 & 0 \\
\hline Aroclor 1254 & $\mathrm{ug} / \mathrm{kg}$ & 23 & 16 & 15 & 64 & 12 & 15 & 1358 & 5 & 12 \\
\hline
\end{tabular}




\begin{tabular}{|c|c|c|c|c|c|c|c|c|c|c|}
\hline Aroclor 1260 & $\mathrm{ug} / \mathrm{kg}$ & 11 & 9 & 7 & 26 & 6 & 14 & 596 & 3 & 8 \\
\hline Aroclor 1262 & $\begin{array}{l}\mathrm{UG} / \\
\mathrm{KG}\end{array}$ & 0 & 0 & 0 & 0 & 0 & 0 & 0 & 0 & 0 \\
\hline Aroclor 1268 & $\begin{array}{l}\mathrm{UG} / \\
\mathrm{KG}\end{array}$ & 0 & 0 & 0 & 0 & 0 & 0 & 0 & 0 & 0 \\
\hline Aroclor 5432 & $\begin{array}{l}\mathrm{UG} / \\
\mathrm{KG} \\
\end{array}$ & 0 & 0 & 0 & 0 & 0 & 0 & 0 & 0 & 0 \\
\hline Aroclor 5442 & $\begin{array}{l}\mathrm{UG} / \\
\mathrm{KG}\end{array}$ & 0 & 0 & 0 & 0 & 0 & 0 & 0 & 0 & 0 \\
\hline Aroclor 5460 & $\mathrm{ug} / \mathrm{kg}$ & 52 & 201 & 86 & 41 & 11 & 4 & 2300 & 0 & 46 \\
\hline EFH (C12-C14) & $\begin{array}{l}\text { MG/ } \\
\text { KG }\end{array}$ & 0 & 5 & 0 & 0 & 2 & 0 & 2 & 0 & 2 \\
\hline EFH (C15-C20) & \begin{tabular}{|l|}
$\mathrm{MG} /$ \\
$\mathrm{KG}$ \\
\end{tabular} & 0 & 53 & 0 & 1 & 71 & 0 & 4 & 0 & 2 \\
\hline EFH (C21-C30) & $\begin{array}{l}\mathrm{mg} / \mathrm{k} \\
\mathrm{g}\end{array}$ & 43 & 140 & 5 & 16 & 252 & 6 & 22 & 16 & 15 \\
\hline EFH (C30-C40) & $\begin{array}{l}\mathrm{mg} / \mathrm{k} \\
\mathrm{g}\end{array}$ & 11 & 5 & 20 & 11 & 16 & 7 & 20 & 14 & 10 \\
\hline $\mathrm{EFH}(\mathrm{C} 8-\mathrm{C} 11)$ & $\begin{array}{l}\mathrm{MG} / \\
\mathrm{KG} \\
\end{array}$ & 0 & 3 & 0 & 0 & 2 & 0 & 2 & 0 & 2 \\
\hline \multicolumn{11}{|l|}{ Jun/126 days } \\
\hline Chemical & $\begin{array}{l}\text { Unit } \\
\text { of } \\
\text { Meas } \\
\text { ure } \\
\end{array}$ & \multicolumn{9}{|c|}{ Standard Deviation } \\
\hline $\begin{array}{l}1,2,3,4,6,7,8- \\
\text { HEPTACHLORODIBENZO-P- } \\
\text { DIOXIN }\end{array}$ & $\mathrm{ng} / \mathrm{kg}$ & 436 & 1516 & 373 & 2046 & 783 & N/A & 344 & 237 & 262 \\
\hline $1,2,3,4,6,7,8-\mathrm{HPCDF}$ & $\mathrm{ng} / \mathrm{kg}$ & 30 & 46 & 20 & 66 & 91 & N/A & 34 & 12 & 18 \\
\hline $1,2,3,4,7,8,9-\mathrm{HPCDF}$ & $\mathrm{ng} / \mathrm{kg}$ & 3 & 4 & 2 & 8 & 9 & N/A & 4 & 2 & 1 \\
\hline $\begin{array}{l}\text { 1,2,3,4,7,8-HEXACHLORODIBENZO- } \\
\text { P-DIOXIN }\end{array}$ & $\mathrm{ng} / \mathrm{kg}$ & 5 & 6 & 4 & 7 & 9 & N/A & 3 & 0 & 1 \\
\hline
\end{tabular}




\begin{tabular}{|c|c|c|c|c|c|c|c|c|c|c|}
\hline $1,2,3,4,7,8-\mathrm{HXCDF}$ & $\mathrm{ng} / \mathrm{kg}$ & 1 & 3 & 1 & 1 & 2 & N/A & 1 & 0 & 1 \\
\hline $\begin{array}{l}\text { 1,2,3,6,7,8-HEXACHLORODIBENZO- } \\
\text { P-DIOXIN }\end{array}$ & $\mathrm{ng} / \mathrm{kg}$ & 11 & 19 & 18 & 31 & 37 & N/A & 10 & 2 & 4 \\
\hline $1,2,3,6,7,8-\mathrm{HXCDF}$ & $\mathrm{ng} / \mathrm{kg}$ & 1 & 3 & 2 & 1 & 4 & $\mathrm{~N} / \mathrm{A}$ & 2 & 0 & 1 \\
\hline $\begin{array}{l}\text { 1,2,3,7,8,9-HEXACHLORODIBENZO- } \\
\text { P-DIOXIN }\end{array}$ & $\mathrm{ng} / \mathrm{kg}$ & 6 & 15 & 7 & 15 & 14 & $\mathrm{~N} / \mathrm{A}$ & 5 & 1 & 2 \\
\hline $1,2,3,7,8,9-\mathrm{HXCDF}$ & $\mathrm{ng} / \mathrm{kg}$ & 3 & 1 & 4 & 4 & 4 & $\mathrm{~N} / \mathrm{A}$ & 3 & 0 & 1 \\
\hline $\begin{array}{l}1,2,3,7,8- \\
\text { PENTACHLORODIBENZOFURAN }\end{array}$ & $\mathrm{ng} / \mathrm{kg}$ & 1 & 1 & 1 & 1 & 1 & $\mathrm{~N} / \mathrm{A}$ & 1 & 0 & 1 \\
\hline $\begin{array}{l}\text { 1,2,3,7,8-PENTACHLORODIBENZO- } \\
\text { P-DIOXIN }\end{array}$ & $\mathrm{ng} / \mathrm{kg}$ & 3 & 1 & 4 & 2 & 3 & $\mathrm{~N} / \mathrm{A}$ & 3 & 0 & 4 \\
\hline $2,3,4,6,7,8-\mathrm{HXCDF}$ & $\mathrm{ng} / \mathrm{kg}$ & 1 & 2 & 2 & 2 & 4 & $\mathrm{~N} / \mathrm{A}$ & 2 & 0 & 1 \\
\hline 2,3,4,7,8-PECDF & $\mathrm{ng} / \mathrm{kg}$ & 2 & 1 & 1 & 1 & 1 & $\mathrm{~N} / \mathrm{A}$ & 1 & 0 & 1 \\
\hline 2,3,7,8-TCDD & $\mathrm{ng} / \mathrm{kg}$ & 2 & 2 & 1 & 0 & 1 & $\mathrm{~N} / \mathrm{A}$ & 1 & 0 & 0 \\
\hline $\begin{array}{l}\text { 2,3,7,8- } \\
\text { TETRACHLORODIBENZOFURAN }\end{array}$ & $\mathrm{ng} / \mathrm{kg}$ & 0 & 0 & 0 & 0 & 1 & $\mathrm{~N} / \mathrm{A}$ & 0 & 0 & 0 \\
\hline OCDD & $\mathrm{ng} / \mathrm{kg}$ & 3454 & 13006 & 21351 & 18368 & 12520 & $\mathrm{~N} / \mathrm{A}$ & 1632 & 6003 & 2859 \\
\hline OCDF & $\mathrm{ng} / \mathrm{kg}$ & 40 & 50 & 26618 & 149 & 203 & $\mathrm{~N} / \mathrm{A}$ & 132 & 34 & 64 \\
\hline TCDD TEQ & $\mathrm{ng} / \mathrm{kg}$ & 20 & 27 & 635 & 34 & 19 & $\mathrm{~N} / \mathrm{A}$ & 5 & 5 & 5 \\
\hline 1,1'-Biphenyl & $\begin{array}{l}\mathrm{UG} / \\
\mathrm{KG}\end{array}$ & 0 & 0 & 0 & 0 & 0 & N/A & 0 & 0 & 4 \\
\hline 1-METHYLNAPHTHALENE & $\begin{array}{l}\mathrm{UG} / \\
\mathrm{KG}\end{array}$ & 0 & 0 & 0 & 0 & 0 & N/A & 0 & 0 & 5 \\
\hline 2-METHYLNAPHTHALENE & $\begin{array}{l}\mathrm{UG} / \\
\mathrm{KG}\end{array}$ & 0 & 0 & 0 & 0 & 0 & N/A & 0 & 0 & 8 \\
\hline ACENAPHTHENE & $\begin{array}{l}\text { UG/ } \\
\mathrm{KG}\end{array}$ & 21 & 0 & 0 & 0 & 0 & $\mathrm{~N} / \mathrm{A}$ & 0 & 0 & 6 \\
\hline ACENAPHTHYLENE & $\mathrm{ug} / \mathrm{kg}$ & 0 & 7 & 0 & 0 & 0 & $\mathrm{~N} / \mathrm{A}$ & 0 & 0 & 11 \\
\hline ANTHRACENE & $\mathrm{ug} / \mathrm{kg}$ & 31 & 9 & 7 & 10 & 0 & $\mathrm{~N} / \mathrm{A}$ & 0 & 0 & 48 \\
\hline AZOBENZENE & $\begin{array}{l}\mathrm{UG} / \\
\mathrm{KG}\end{array}$ & 0 & 0 & 0 & 0 & 0 & $\mathrm{~N} / \mathrm{A}$ & 0 & 0 & 0 \\
\hline
\end{tabular}




\begin{tabular}{|c|c|c|c|c|c|c|c|c|c|c|}
\hline BENZO(A)ANTHRACENE & $\mathrm{ug} / \mathrm{kg}$ & 64 & 25 & 27 & 11 & 29 & N/A & 15 & 12 & 111 \\
\hline BENZO(A)PYRENE & $\mathrm{ug} / \mathrm{kg}$ & 56 & 10 & 24 & 8 & 23 & N/A & 13 & 14 & 270 \\
\hline BENZO(B)FLUORANTHENE & $\mathrm{ug} / \mathrm{kg}$ & 70 & 22 & 29 & 7 & 40 & N/A & 16 & 22 & 486 \\
\hline Benzo(e)pyrene & $\mathrm{ug} / \mathrm{kg}$ & 30 & 7 & 17 & 7 & 19 & N/A & 11 & 16 & 248 \\
\hline BENZO(G,H,I)PERYLENE & $\mathrm{ug} / \mathrm{kg}$ & 29 & 5 & 16 & 4 & 11 & N/A & 9 & 10 & 577 \\
\hline BENZO(K)FLUORANTHENE & $\mathrm{ug} / \mathrm{kg}$ & 23 & 8 & 12 & 7 & 18 & N/A & 10 & 6 & 92 \\
\hline bis(2-Ethylhexyl)phthalate & $\mathrm{ug} / \mathrm{kg}$ & 0 & 0 & 0 & 0 & 0 & $\mathrm{~N} / \mathrm{A}$ & 0 & 0 & 0 \\
\hline Butylbenzylphthalate & $\mathrm{ug} / \mathrm{kg}$ & 0 & 0 & 0 & 0 & 0 & N/A & 0 & 0 & 0 \\
\hline Chrysene & $\mathrm{ug} / \mathrm{kg}$ & 69 & 23 & 25 & 10 & 26 & N/A & 16 & 25 & 135 \\
\hline Di-n-butylphthalate & $\mathrm{ug} / \mathrm{kg}$ & 0 & 0 & 0 & 0 & 0 & N/A & 0 & 0 & 0 \\
\hline DIBENZO(A,H)ANTHRACENE & $\mathrm{ug} / \mathrm{kg}$ & 10 & 0 & 7 & 0 & 0 & N/A & 0 & 0 & 138 \\
\hline Di-n-octylphthalate & $\mathrm{ug} / \mathrm{kg}$ & 0 & 0 & 0 & 0 & 0 & N/A & 0 & 0 & 0 \\
\hline FLUORANTHENE & $\mathrm{ug} / \mathrm{kg}$ & 158 & 42 & 49 & 22 & 48 & N/A & 26 & 32 & 168 \\
\hline FLUORENE & $\begin{array}{l}\mathrm{UG} / \\
\mathrm{KG}\end{array}$ & 13 & 0 & 0 & 0 & 0 & $\mathrm{~N} / \mathrm{A}$ & 0 & 0 & 3 \\
\hline INDENO(1,2,3-CD)PYRENE & $\mathrm{ug} / \mathrm{kg}$ & 29 & 6 & 12 & 3 & 15 & N/A & 8 & 11 & 326 \\
\hline $\begin{array}{l}\text { METHANAMINE, N-METHYL-N- } \\
\text { NITROSO }\end{array}$ & $\begin{array}{l}\text { UG/ } \\
\text { KG }\end{array}$ & 0 & 0 & 0 & 0 & 0 & N/A & 0 & 0 & 0 \\
\hline NAPHTHALENE & $\begin{array}{l}\mathrm{UG} / \\
\mathrm{KG}\end{array}$ & 0 & 0 & 0 & 0 & 0 & N/A & 0 & & 6 \\
\hline PHENANTHRENE & $\mathrm{ug} / \mathrm{kg}$ & 139 & 20 & 19 & 23 & 25 & N/A & 9 & 15 & 153 \\
\hline PYRENE & $\mathrm{ug} / \mathrm{kg}$ & 142 & 34 & 45 & 20 & 39 & N/A & 23 & 25 & 135 \\
\hline Aroclor 1016 & $\begin{array}{l}\mathrm{UG} / \\
\mathrm{KG}\end{array}$ & 0 & 0 & 0 & 0 & 0 & N/A & 0 & 0 & 0 \\
\hline Aroclor 1221 & $\begin{array}{l}\mathrm{UG} / \\
\mathrm{KG} \\
\end{array}$ & 0 & 0 & 0 & 0 & 0 & N/A & 0 & 0 & 0 \\
\hline Aroclor 1232 & $\begin{array}{l}\mathrm{UG} / \\
\mathrm{KG}\end{array}$ & 0 & 0 & 0 & 0 & 0 & $\mathrm{~N} / \mathrm{A}$ & 0 & 0 & 0 \\
\hline Aroclor 1242 & $\begin{array}{l}\mathrm{UG} / \\
\mathrm{KG}\end{array}$ & 0 & 0 & 0 & 0 & 0 & N/A & 0 & 0 & 0 \\
\hline
\end{tabular}




\begin{tabular}{|c|c|c|c|c|c|c|c|c|c|c|}
\hline Aroclor 1248 & $\begin{array}{l}\text { UG/ } \\
\text { KG }\end{array}$ & 0 & 0 & 0 & 0 & 0 & N/A & 0 & 0 & 0 \\
\hline Aroclor 1254 & $\mathrm{ug} / \mathrm{kg}$ & 19 & 6 & 28 & 8 & 12 & N/A & 12 & 4 & 23 \\
\hline Aroclor 1260 & $\mathrm{ug} / \mathrm{kg}$ & 8 & 13 & 7 & 4 & 11 & N/A & 7 & 2 & 13 \\
\hline Aroclor 1262 & $\begin{array}{l}\text { UG/ } \\
\text { KG }\end{array}$ & 0 & 0 & 0 & 0 & 0 & N/A & 0 & 0 & 0 \\
\hline Aroclor 1268 & $\begin{array}{l}\text { UG/ } \\
\text { KG }\end{array}$ & 0 & 0 & 0 & 0 & 0 & N/A & 0 & 0 & 0 \\
\hline Aroclor 5432 & $\begin{array}{l}\mathrm{UG} / \\
\mathrm{KG}\end{array}$ & 0 & 0 & 0 & 0 & 0 & N/A & 0 & 0 & 0 \\
\hline Aroclor 5442 & $\begin{array}{l}\text { UG/ } \\
\text { KG }\end{array}$ & 0 & 0 & 0 & 0 & 0 & N/A & 0 & 0 & 0 \\
\hline Aroclor 5460 & $\mathrm{ug} / \mathrm{kg}$ & 59 & 47 & 72 & 3 & 29 & N/A & 20 & 0 & 17 \\
\hline EFH (C12-C14) & $\begin{array}{l}\mathrm{MG} / \\
\mathrm{KG}\end{array}$ & 0 & 0 & 0 & 0 & 0 & N/A & 0 & 0 & 2 \\
\hline EFH (C15-C20) & $\begin{array}{l}\text { MG/ } \\
\text { KG }\end{array}$ & 0 & 7 & 3 & 1 & 4 & N/A & 0 & 0 & 2 \\
\hline EFH (C21-C30) & $\begin{array}{l}\mathrm{mg} / \mathrm{k} \\
\mathrm{g}\end{array}$ & 12 & 10 & 22 & 14 & 7 & N/A & 5 & 10 & 14 \\
\hline EFH (C30-C40) & $\begin{array}{l}\mathrm{mg} / \mathrm{k} \\
\mathrm{g}\end{array}$ & 42 & 38 & 21 & 12 & 25 & N/A & 8 & 18 & 15 \\
\hline EFH (C8-C11) & $\begin{array}{l}\text { MG/ } \\
\mathrm{KG}\end{array}$ & 0 & 0 & 0 & 0 & 0 & N/A & 0 & 0 & 1 \\
\hline \multicolumn{11}{|l|}{ Oct/244 days } \\
\hline Chemical & $\begin{array}{l}\text { Unit } \\
\text { of } \\
\text { Meas } \\
\text { ure }\end{array}$ & \multicolumn{9}{|c|}{ Standard Deviation } \\
\hline $\begin{array}{l}1,2,3,4,6,7,8- \\
\text { HEPTACHLORODIBENZO-P- } \\
\text { DIOXIN }\end{array}$ & $\mathrm{ng} / \mathrm{kg}$ & 6077 & 758 & 1718 & 665 & 2901 & 554 & 1078 & 569 & 229 \\
\hline 1,2,3,4,6,7,8-HPCDF & $\mathrm{ng} / \mathrm{kg}$ & 827 & 22 & 113 & 78 & 19 & 29 & 48 & 27 & 15 \\
\hline
\end{tabular}




\begin{tabular}{|c|c|c|c|c|c|c|c|c|c|c|}
\hline 1,2,3,4,7,8,9-HPCDF & $\mathrm{ng} / \mathrm{kg}$ & 54 & 1 & 8 & 4 & 2 & 4 & 4 & 1 & 1 \\
\hline $\begin{array}{l}\text { 1,2,3,4,7,8-HEXACHLORODIBENZO- } \\
\text { P-DIOXIN }\end{array}$ & $\mathrm{ng} / \mathrm{kg}$ & 22 & 1 & 6 & 3 & 2 & 2 & 8 & 1 & 1 \\
\hline $1,2,3,4,7,8-\mathrm{HXCDF}$ & $\mathrm{ng} / \mathrm{kg}$ & 11 & 1 & 3 & 2 & 1 & 2 & 4 & 0 & 3 \\
\hline $\begin{array}{l}\text { 1,2,3,6,7,8-HEXACHLORODIBENZO- } \\
\text { P-DIOXIN }\end{array}$ & $\mathrm{ng} / \mathrm{kg}$ & 257 & 23 & 51 & 24 & 59 & 10 & 38 & 9 & 5 \\
\hline 1,2,3,6,7,8-HXCDF & $\mathrm{ng} / \mathrm{kg}$ & 12 & 1 & 2 & 1 & 1 & 1 & 1 & 0 & 1 \\
\hline $\begin{array}{l}\text { 1,2,3,7,8,9-HEXACHLORODIBENZO- } \\
\text { P-DIOXIN }\end{array}$ & $\mathrm{ng} / \mathrm{kg}$ & 54 & 4 & 13 & 5 & 19 & 4 & 12 & 2 & 2 \\
\hline $1,2,3,7,8,9-\mathrm{HXCDF}$ & $\mathrm{ng} / \mathrm{kg}$ & 5 & 0 & 0 & 0 & 0 & 0 & 0 & 2 & 0 \\
\hline $\begin{array}{l}1,2,3,7,8- \\
\text { PENTACHLORODIBENZOFURAN }\end{array}$ & $\mathrm{ng} / \mathrm{kg}$ & 3 & 1 & 1 & 1 & 1 & 1 & 1 & 0 & 1 \\
\hline $\begin{array}{l}\text { 1,2,3,7,8-PENTACHLORODIBENZO- } \\
\text { P-DIOXIN }\end{array}$ & $\mathrm{ng} / \mathrm{kg}$ & 11 & 1 & 3 & 2 & 2 & 1 & 6 & 0 & 1 \\
\hline 2,3,4,6,7,8-HXCDF & $\mathrm{ng} / \mathrm{kg}$ & 27 & 2 & 4 & 3 & 0 & 2 & 3 & 0 & 1 \\
\hline 2,3,4,7,8-PECDF & $\mathrm{ng} / \mathrm{kg}$ & 5 & 2 & 2 & 0 & 0 & 1 & 1 & 0 & 2 \\
\hline $2,3,7,8$-TCDD & $\mathrm{ng} / \mathrm{kg}$ & 2 & 1 & 1 & 1 & 1 & 1 & 2 & 0 & 0 \\
\hline $\begin{array}{l}2,3,7,8- \\
\text { TETRACHLORODIBENZOFURAN }\end{array}$ & $\mathrm{ng} / \mathrm{kg}$ & 1 & 0 & 0 & 0 & 0 & 0 & 1 & 0 & 0 \\
\hline OCDD & & 48267 & 4678 & 9008 & 13162 & 14696 & 6723 & 18256 & 11601 & 2100 \\
\hline OCDF & $\mathrm{ng} / \mathrm{kg}$ & 2154 & 66 & 338 & 240 & 64 & 105 & 73 & 97 & 65 \\
\hline TCDD TEQ & $\mathrm{ng} / \mathrm{kg}$ & 270 & 10 & 28 & 11 & 41 & 8 & 30 & 11 & 4 \\
\hline 1,1'-Biphenyl & $\begin{array}{l}\mathrm{UG} / \\
\mathrm{KG}\end{array}$ & 0 & 0 & 0 & 0 & 0 & 0 & 0 & 0 & 0 \\
\hline 1-METHYLNAPHTHALENE & $\begin{array}{l}\mathrm{UG} / \\
\mathrm{KG} \\
\end{array}$ & 8 & 4 & 6 & 4 & 10 & 4 & 5 & 0 & 60 \\
\hline 2-METHYLNAPHTHALENE & $\begin{array}{l}\mathrm{UG} / \\
\mathrm{KG}\end{array}$ & 9 & 3 & 9 & 5 & 10 & 1 & 6 & 0 & 77 \\
\hline ACENAPHTHENE & $\begin{array}{l}\mathrm{UG} / \\
\mathrm{KG}\end{array}$ & 11 & 0 & 7 & 15 & 76 & 8 & 5 & 0 & 3 \\
\hline ACENAPHTHYLENE & $\mathrm{ug} / \mathrm{kg}$ & 8 & 2 & 7 & 0 & 3 & 3 & 5 & 0 & 16 \\
\hline
\end{tabular}




\begin{tabular}{|c|c|c|c|c|c|c|c|c|c|c|}
\hline ANTHRACENE & $\mathrm{ug} / \mathrm{kg}$ & 11 & 18 & 9 & 9 & 85 & 10 & 4 & 0 & 88 \\
\hline AZOBENZENE & $\begin{array}{l}\mathrm{UG} / \\
\mathrm{KG}\end{array}$ & 0 & 0 & 0 & 0 & 0 & 0 & 0 & 0 & 0 \\
\hline BENZO(A)ANTHRACENE & $\mathrm{ug} / \mathrm{kg}$ & 13 & 209 & 24 & 27 & 148 & 34 & 11 & 8 & 259 \\
\hline BENZO(A)PYRENE & $\mathrm{ug} / \mathrm{kg}$ & 7 & 131 & 19 & 25 & 128 & 30 & 9 & 0 & 614 \\
\hline BENZO(B)FLUORANTHENE & $\mathrm{ug} / \mathrm{kg}$ & 29 & 195 & 34 & 34 & 154 & 40 & 12 & 5 & 858 \\
\hline Benzo(e)pyrene & $\mathrm{ug} / \mathrm{kg}$ & 21 & 83 & 33 & 34 & 74 & 38 & 22 & 0 & 432 \\
\hline BENZO(G,H,I)PERYLENE & $\mathrm{ug} / \mathrm{kg}$ & 3 & 50 & 7 & 10 & 67 & 18 & 3 & 6 & 288 \\
\hline BENZO(K)FLUORANTHENE & $\mathrm{ug} / \mathrm{kg}$ & 16 & 81 & 13 & 15 & 75 & 16 & 6 & 0 & 255 \\
\hline bis(2-Ethylhexyl)phthalate & $\mathrm{ug} / \mathrm{kg}$ & 87 & 48 & 42 & 47 & 261 & 53 & 44 & 45 & 207 \\
\hline Butylbenzylphthalate & $\mathrm{ug} / \mathrm{kg}$ & 0 & 0 & 34 & 0 & 0 & 33 & 0 & 0 & 0 \\
\hline Chrysene & $\mathrm{ug} / \mathrm{kg}$ & 51 & 232 & 57 & 33 & 148 & 40 & 20 & 3 & 460 \\
\hline Di-n-butylphthalate & $\mathrm{ug} / \mathrm{kg}$ & 41 & 76 & 0 & 67 & 0 & 0 & 0 & 0 & 0 \\
\hline $\operatorname{DIBENZO}(\mathrm{A}, \mathrm{H}) \mathrm{ANTHRACENE}$ & $\mathrm{ug} / \mathrm{kg}$ & 0 & 21 & 5 & 6 & 22 & 8 & 0 & 0 & 81 \\
\hline Di-n-octylphthalate & $\mathrm{ug} / \mathrm{kg}$ & 0 & 0 & 0 & 0 & 0 & 0 & 0 & 0 & 48 \\
\hline FLUORANTHENE & $\mathrm{ug} / \mathrm{kg}$ & 217 & 371 & 90 & 60 & 325 & 64 & 85 & 0 & 662 \\
\hline FLUORENE & $\mathrm{ug} / \mathrm{kg}$ & 11 & 0 & 5 & 12 & 54 & 5 & 5 & 0 & 5 \\
\hline INDENO(1,2,3-CD)PYRENE & $\mathrm{ug} / \mathrm{kg}$ & 5 & 52 & 6 & 11 & 65 & 16 & 3 & 0 & 367 \\
\hline $\begin{array}{l}\text { METHANAMINE, N-METHYL-N- } \\
\text { NITROSO }\end{array}$ & $\begin{array}{l}\mathrm{UG} / \\
\mathrm{KG}\end{array}$ & 0 & 0 & 0 & 0 & 0 & 0 & 0 & 0 & 0 \\
\hline NAPHTHALENE & $\begin{array}{l}\mathrm{UG} / \\
\mathrm{KG}\end{array}$ & 6 & 5 & 5 & 4 & 65 & 4 & 4 & 0 & 50 \\
\hline PHENANTHRENE & $\mathrm{ug} / \mathrm{kg}$ & 142 & 66 & 71 & 68 & 359 & 40 & 53 & 0 & 534 \\
\hline PYRENE & $\mathrm{ug} / \mathrm{kg}$ & 145 & 339 & 72 & 55 & 273 & 45 & 59 & 0 & 255 \\
\hline Aroclor 1016 & $\begin{array}{l}\text { UG/ } \\
\text { KG }\end{array}$ & 0 & 0 & 0 & 9 & 0 & 0 & 0 & 0 & 0 \\
\hline Aroclor 1221 & $\begin{array}{l}\mathrm{UG} / \\
\mathrm{KG}\end{array}$ & 0 & 0 & 0 & 0 & 0 & 0 & 0 & 0 & 0 \\
\hline Aroclor 1232 & UG/ & 0 & 0 & 0 & 0 & 0 & 0 & 0 & 0 & 0 \\
\hline
\end{tabular}




\begin{tabular}{|c|c|c|c|c|c|c|c|c|c|c|}
\hline & KG & & & & & & & & & \\
\hline Aroclor 1242 & $\begin{array}{l}\mathrm{UG} / \\
\mathrm{KG}\end{array}$ & 0 & 0 & 0 & 0 & 0 & 0 & 0 & 0 & 0 \\
\hline Aroclor 1248 & $\begin{array}{l}\mathrm{UG} / \\
\mathrm{KG}\end{array}$ & 0 & 0 & 0 & 0 & 0 & 0 & 0 & 0 & 0 \\
\hline Aroclor 1254 & $\mathrm{ug} / \mathrm{kg}$ & 15 & 15 & 22 & 13 & 35 & 7 & 11 & 31 & 2 \\
\hline Aroclor 1260 & $\mathrm{ug} / \mathrm{kg}$ & 8 & 16 & 12 & 4 & 6 & 5 & 9 & 11 & 2 \\
\hline Aroclor 1262 & $\begin{array}{l}\mathrm{UG} / \\
\mathrm{KG}\end{array}$ & 0 & 0 & 0 & 0 & 0 & 0 & 0 & 0 & 0 \\
\hline Aroclor 1268 & $\begin{array}{l}\text { UG/ } \\
\text { KG }\end{array}$ & 0 & 0 & 0 & 0 & 0 & 0 & 0 & 0 & 0 \\
\hline Aroclor 5432 & $\begin{array}{l}\mathrm{UG} / \\
\mathrm{KG}\end{array}$ & 0 & 0 & 0 & 0 & 0 & 0 & 0 & 0 & 0 \\
\hline Aroclor 5442 & $\begin{array}{l}\mathrm{UG} / \\
\mathrm{KG}\end{array}$ & 0 & 0 & 0 & 0 & 0 & 0 & 0 & 0 & 0 \\
\hline Aroclor 5460 & $\mathrm{ug} / \mathrm{kg}$ & 23 & 7 & 10 & 12 & 9 & 25 & 30 & 53 & 0 \\
\hline EFH (C12-C14) & $\begin{array}{l}\text { MG/ } \\
\text { KG }\end{array}$ & 0 & & 0 & 0 & & 0 & 0 & 0 & 0 \\
\hline EFH (C15-C20) & $\begin{array}{l}\mathrm{MG} / \\
\mathrm{KG}\end{array}$ & 6 & & 10 & 29 & & 4 & 0 & 0 & 22 \\
\hline EFH (C21-C30) & $\begin{array}{l}\mathrm{mg} / \mathrm{k} \\
\mathrm{g}\end{array}$ & 28 & & 8 & 54 & & 11 & 22 & 15 & 60 \\
\hline EFH (C30-C40) & $\begin{array}{l}\mathrm{mg} / \mathrm{k} \\
\mathrm{g}\end{array}$ & 89 & & 16 & 139 & & 34 & 58 & 40 & 108 \\
\hline EFH (C8-C11) & $\begin{array}{l}\text { MG/ } \\
\mathrm{KG}\end{array}$ & 0 & & 0 & 0 & & 0 & 0 & 0 & 0 \\
\hline \multicolumn{11}{|l|}{ Feb/0 days } \\
\hline Chemical & $\begin{array}{l}\text { Unit } \\
\text { of } \\
\text { Meas } \\
\text { ure }\end{array}$ & \multicolumn{9}{|c|}{ Standard Error of the Mean } \\
\hline $1,2,3,4,6,7,8-$ & $\mathrm{ng} / \mathrm{kg}$ & 616 & 636 & 675 & 2244 & 996 & 366 & 356 & 140 & 32 \\
\hline
\end{tabular}




\begin{tabular}{|c|c|c|c|c|c|c|c|c|c|c|}
\hline $\begin{array}{l}\text { HEPTACHLORODIBENZO-P- } \\
\text { DIOXIN }\end{array}$ & & & & & & & & & & \\
\hline 1,2,3,4,6,7,8-HPCDF & $\mathrm{ng} / \mathrm{kg}$ & 85 & 29 & 17 & 263 & 168 & 8 & 21 & 16 & 6 \\
\hline 1,2,3,4,7,8,9-HPCDF & $\mathrm{ng} / \mathrm{kg}$ & 6 & 2 & 2 & 16 & 2 & 1 & 2 & 0 & 0 \\
\hline $\begin{array}{l}\text { 1,2,3,4,7,8-HEXACHLORODIBENZO- } \\
\text { P-DIOXIN }\end{array}$ & $\mathrm{ng} / \mathrm{kg}$ & 3 & 5 & 2 & 16 & 4 & 1 & 3 & 0 & 0 \\
\hline 1,2,3,4,7,8-HXCDF & $\mathrm{ng} / \mathrm{kg}$ & 1 & 1 & 1 & 5 & 3 & 0 & 1 & 0 & 0 \\
\hline $\begin{array}{l}\text { 1,2,3,6,7,8-HEXACHLORODIBENZO- } \\
\text { P-DIOXIN }\end{array}$ & $\mathrm{ng} / \mathrm{kg}$ & 24 & 23 & 9 & 98 & 25 & 7 & 12 & 3 & 1 \\
\hline 1,2,3,6,7,8-HXCDF & $\mathrm{ng} / \mathrm{kg}$ & 3 & 1 & 1 & 22 & 18 & 1 & 1 & 1 & 1 \\
\hline $\begin{array}{l}\text { 1,2,3,7,8,9-HEXACHLORODIBENZO- } \\
\text { P-DIOXIN }\end{array}$ & $\mathrm{ng} / \mathrm{kg}$ & 5 & 11 & 3 & 37 & 9 & 1 & 6 & 1 & 0 \\
\hline 1,2,3,7,8,9-HXCDF & $\mathrm{ng} / \mathrm{kg}$ & 0 & 0 & 0 & 1 & 1 & 1 & 1 & 0 & 1 \\
\hline $\begin{array}{l}1,2,3,7,8- \\
\text { PENTACHLORODIBENZOFURAN }\end{array}$ & $\mathrm{ng} / \mathrm{kg}$ & 0 & 0 & 1 & 2 & 1 & 0 & 0 & 0 & 0 \\
\hline $\begin{array}{l}\text { 1,2,3,7,8-PENTACHLORODIBENZO- } \\
\text { P-DIOXIN }\end{array}$ & $\mathrm{ng} / \mathrm{kg}$ & 1 & 1 & 1 & 11 & 2 & 1 & 2 & 0 & 0 \\
\hline 2,3,4,6,7,8-HXCDF & $\mathrm{ng} / \mathrm{kg}$ & 3 & 1 & 1 & 9 & 1 & 0 & 2 & 0 & 0 \\
\hline 2,3,4,7,8-PECDF & $\mathrm{ng} / \mathrm{kg}$ & 0 & 0 & 0 & 2 & 0 & 0 & 1 & 0 & 0 \\
\hline 2,3,7,8-TCDD & $\mathrm{ng} / \mathrm{kg}$ & 0 & 0 & 0 & 2 & 0 & 0 & 0 & 0 & 0 \\
\hline $\begin{array}{l}\text { 2,3,7,8- } \\
\text { TETRACHLORODIBENZOFURAN }\end{array}$ & $\mathrm{ng} / \mathrm{kg}$ & 0 & 0 & 0 & 1 & 0 & 0 & 0 & 0 & 0 \\
\hline OCDD & & 4394 & 2444 & 2337 & 20072 & 5301 & 7758 & 2956 & 3240 & 619 \\
\hline $\mathrm{OCDF}$ & $\mathrm{ng} / \mathrm{kg}$ & 191 & 46 & 53 & 375 & 59 & 11 & 41 & 25 & 24 \\
\hline TCDD TEQ & $\mathrm{ng} / \mathrm{kg}$ & 13 & 12 & 8 & 61 & 15 & 8 & 6 & 3 & 1 \\
\hline 1,1'-Biphenyl & $\begin{array}{l}\mathrm{UG} / \\
\mathrm{KG}\end{array}$ & 0 & 0 & 0 & 0 & 0 & 0 & 0 & 0 & 2 \\
\hline 1-METHYLNAPHTHALENE & $\begin{array}{l}\mathrm{UG} / \\
\mathrm{KG}\end{array}$ & 0 & 0 & 0 & 0 & 0 & 0 & 0 & 0 & 0 \\
\hline 2-METHYLNAPHTHALENE & $\begin{array}{l}\mathrm{UG} / \\
\mathrm{KG}\end{array}$ & 0 & 0 & 0 & 0 & 0 & 0 & 0 & 0 & 10 \\
\hline
\end{tabular}




\begin{tabular}{|c|c|c|c|c|c|c|c|c|c|c|}
\hline ACENAPHTHENE & $\begin{array}{l}\mathrm{UG} / \\
\mathrm{KG}\end{array}$ & 0 & 0 & 0 & 0 & 0 & 0 & 0 & 16 & 0 \\
\hline ACENAPHTHYLENE & $\mathrm{ug} / \mathrm{kg}$ & 0 & 0 & 8 & 0 & 0 & 0 & 0 & 0 & 4 \\
\hline ANTHRACENE & $\mathrm{ug} / \mathrm{kg}$ & 4 & 0 & 6 & 0 & 0 & 0 & 6 & 22 & 21 \\
\hline AZOBENZENE & $\begin{array}{l}\mathrm{UG} / \\
\mathrm{KG}\end{array}$ & 0 & 0 & 0 & 0 & 0 & 0 & 0 & 0 & 0 \\
\hline BENZO(A)ANTHRACENE & $\mathrm{ug} / \mathrm{kg}$ & 5 & 13 & 9 & 0 & 0 & 13 & 11 & 38 & 54 \\
\hline BENZO(A)PYRENE & $\mathrm{ug} / \mathrm{kg}$ & 5 & 11 & 8 & 7 & 0 & 13 & 12 & 44 & 114 \\
\hline BENZO(B)FLUORANTHENE & $\mathrm{ug} / \mathrm{kg}$ & 10 & 10 & 9 & 2 & 0 & 14 & 12 & 54 & 227 \\
\hline Benzo(e)pyrene & $\mathrm{ug} / \mathrm{kg}$ & 4 & 5 & 16 & 7 & 12 & 6 & 8 & 26 & 112 \\
\hline BENZO(G,H,I)PERYLENE & $\mathrm{ug} / \mathrm{kg}$ & 2 & 8 & 14 & 2 & 0 & 5 & 8 & 20 & 532 \\
\hline BENZO(K)FLUORANTHENE & $\mathrm{ug} / \mathrm{kg}$ & 2 & 0 & 4 & 0 & 0 & 6 & 0 & 18 & 62 \\
\hline bis(2-Ethylhexyl)phthalate & $\mathrm{ug} / \mathrm{kg}$ & 0 & 0 & 0 & 0 & 0 & 0 & 0 & 0 & 0 \\
\hline Butylbenzylphthalate & $\mathrm{ug} / \mathrm{kg}$ & 0 & 0 & 0 & 0 & 0 & 0 & 0 & 0 & 0 \\
\hline Chrysene & $\mathrm{ug} / \mathrm{kg}$ & 15 & 7 & 17 & 0 & 0 & 16 & 15 & 50 & 143 \\
\hline Di-n-butylphthalate & $\mathrm{ug} / \mathrm{kg}$ & 0 & 0 & 0 & 0 & 0 & 0 & 0 & 0 & 0 \\
\hline $\operatorname{DIBENZO}(\mathrm{A}, \mathrm{H}) \mathrm{ANTHRACENE}$ & $\mathrm{ug} / \mathrm{kg}$ & 0 & 0 & 0 & 0 & 0 & 0 & 0 & 6 & 69 \\
\hline Di-n-octylphthalate & $\mathrm{ug} / \mathrm{kg}$ & 0 & 0 & 0 & 0 & 0 & 0 & 0 & 0 & 0 \\
\hline FLUORANTHENE & $\mathrm{ug} / \mathrm{kg}$ & 27 & 14 & 44 & 5 & 2 & 30 & 39 & 96 & 70 \\
\hline FLUORENE & $\mathrm{ug} / \mathrm{kg}$ & 0 & 0 & 0 & 0 & 0 & 0 & 0 & 10 & 18 \\
\hline INDENO(1,2,3-CD)PYRENE & $\mathrm{ug} / \mathrm{kg}$ & 2 & 0 & 7 & 0 & 0 & 8 & 7 & 17 & 411 \\
\hline $\begin{array}{l}\text { METHANAMINE, N-METHYL-N- } \\
\text { NITROSO }\end{array}$ & $\begin{array}{l}\mathrm{UG} / \\
\mathrm{KG}\end{array}$ & 0 & 0 & 0 & 0 & 0 & 0 & 0 & 0 & 1 \\
\hline NAPHTHALENE & $\begin{array}{l}\mathrm{UG} / \\
\mathrm{KG}\end{array}$ & 0 & 0 & 0 & 0 & 0 & 0 & 0 & 0 & 9 \\
\hline PHENANTHRENE & $\mathrm{ug} / \mathrm{kg}$ & 15 & 10 & 47 & 10 & 0 & 27 & 28 & 100 & 89 \\
\hline PYRENE & $\mathrm{ug} / \mathrm{kg}$ & 24 & 20 & 27 & 3 & 15 & 29 & 33 & 94 & 43 \\
\hline Aroclor 1016 & $\begin{array}{l}\mathrm{UG} / \\
\mathrm{KG}\end{array}$ & 0 & 0 & 0 & 0 & 0 & 0 & 0 & 0 & 0 \\
\hline
\end{tabular}




\begin{tabular}{|c|c|c|c|c|c|c|c|c|c|c|}
\hline Aroclor 1221 & $\begin{array}{l}\text { UG/ } \\
\text { KG }\end{array}$ & 0 & 0 & 0 & 0 & 0 & 0 & 0 & 0 & 0 \\
\hline Aroclor 1232 & $\begin{array}{l}\mathrm{UG} / \\
\mathrm{KG}\end{array}$ & 0 & 0 & 0 & 0 & 0 & 0 & 0 & 0 & 0 \\
\hline Aroclor 1242 & $\begin{array}{l}\text { UG/ } \\
\text { KG }\end{array}$ & 0 & 0 & 0 & 0 & 0 & 0 & 0 & 0 & 0 \\
\hline Aroclor 1248 & $\begin{array}{l}\mathrm{UG} / \\
\mathrm{KG}\end{array}$ & 0 & 0 & 0 & 0 & 0 & 0 & 0 & 0 & 0 \\
\hline Aroclor 1254 & $\mathrm{ug} / \mathrm{kg}$ & 10 & 7 & 7 & 29 & 5 & 7 & 607 & 2 & 5 \\
\hline Aroclor 1260 & $\mathrm{ug} / \mathrm{kg}$ & 5 & 4 & 3 & 12 & 3 & 6 & 266 & 1 & 3 \\
\hline Aroclor 1262 & $\begin{array}{l}\text { UG/ } \\
\mathrm{KG}\end{array}$ & 0 & 0 & 0 & 0 & 0 & 0 & 0 & 0 & 0 \\
\hline Aroclor 1268 & $\begin{array}{l}\mathrm{UG} / \\
\mathrm{KG}\end{array}$ & 0 & 0 & 0 & 0 & 0 & 0 & 0 & 0 & 0 \\
\hline Aroclor 5432 & $\begin{array}{l}\text { UG/ } \\
\text { KG }\end{array}$ & 0 & 0 & 0 & 0 & 0 & 0 & 0 & 0 & 0 \\
\hline Aroclor 5442 & $\begin{array}{l}\mathrm{UG} / \\
\mathrm{KG}\end{array}$ & 0 & 0 & 0 & 0 & 0 & 0 & 0 & 0 & 0 \\
\hline Aroclor 5460 & $\mathrm{ug} / \mathrm{kg}$ & 23 & 90 & 38 & 18 & 5 & 2 & 1029 & 0 & 21 \\
\hline EFH (C12-C14) & $\begin{array}{l}\mathrm{MG} / \\
\mathrm{KG}\end{array}$ & 0 & 2 & 0 & 0 & 1 & 0 & 1 & 0 & 1 \\
\hline EFH (C15-C20) & $\begin{array}{l}\mathrm{MG} / \\
\mathrm{KG}\end{array}$ & 0 & 24 & 0 & 1 & 32 & 0 & 2 & 0 & 1 \\
\hline EFH (C21-C30) & $\begin{array}{l}\mathrm{mg} / \mathrm{k} \\
\mathrm{g}\end{array}$ & 19 & 63 & 2 & 7 & 113 & 3 & 10 & 7 & 7 \\
\hline EFH (C30-C40) & $\begin{array}{l}\mathrm{mg} / \mathrm{k} \\
\mathrm{g}\end{array}$ & 5 & 2 & 9 & 5 & 7 & 3 & 9 & 6 & 5 \\
\hline $\mathrm{EFH}(\mathrm{C} 8-\mathrm{C} 11)$ & $\begin{array}{l}\text { MG/ } \\
\text { KG }\end{array}$ & 0 & 1 & 0 & 0 & 1 & 0 & 1 & 0 & 1 \\
\hline \multicolumn{11}{|l|}{ Jun/126 days } \\
\hline Chemical & $\begin{array}{l}\text { Unit } \\
\text { of }\end{array}$ & $\begin{array}{l}\text { Standar } \\
\mathrm{d} \text { Error }\end{array}$ & & & & & & & & \\
\hline
\end{tabular}




\begin{tabular}{|c|c|c|c|c|c|c|c|c|c|}
\hline & $\begin{array}{l}\text { Meas } \\
\text { ure }\end{array}$ & $\begin{array}{l}\text { of the } \\
\text { Mean }\end{array}$ & & & & & & & \\
\hline $\begin{array}{l}1,2,3,4,6,7,8- \\
\text { HEPTACHLORODIBENZO-P- } \\
\text { DIOXIN }\end{array}$ & $\mathrm{ng} / \mathrm{kg}$ & 195 & 678 & 167 & 915 & 350 & 130 & 106 & 99 \\
\hline $1,2,3,4,6,7,8-\mathrm{HPCDF}$ & $\mathrm{ng} / \mathrm{kg}$ & 14 & 21 & 9 & 29 & 41 & 13 & 5 & 7 \\
\hline $1,2,3,4,7,8,9-\mathrm{HPCDF}$ & $\mathrm{ng} / \mathrm{kg}$ & 1 & 2 & 1 & 4 & 4 & 1 & 1 & 0 \\
\hline $\begin{array}{l}\text { 1,2,3,4,7,8-HEXACHLORODIBENZO- } \\
\text { P-DIOXIN }\end{array}$ & $\mathrm{ng} / \mathrm{kg}$ & 2 & 3 & 2 & 3 & 4 & 1 & 0 & 0 \\
\hline $1,2,3,4,7,8-\mathrm{HXCDF}$ & $\mathrm{ng} / \mathrm{kg}$ & 1 & 1 & 1 & 0 & 1 & 0 & 0 & 0 \\
\hline $\begin{array}{l}\text { 1,2,3,6,7,8-HEXACHLORODIBENZO- } \\
\text { P-DIOXIN }\end{array}$ & $\mathrm{ng} / \mathrm{kg}$ & 5 & 9 & 8 & 14 & 17 & 4 & 1 & 1 \\
\hline $1,2,3,6,7,8-\mathrm{HXCDF}$ & $\mathrm{ng} / \mathrm{kg}$ & 0 & 1 & 1 & 0 & 2 & 1 & 0 & 0 \\
\hline $\begin{array}{l}\text { 1,2,3,7,8,9-HEXACHLORODIBENZO- } \\
\text { P-DIOXIN }\end{array}$ & $\mathrm{ng} / \mathrm{kg}$ & 2 & 7 & 3 & 7 & 6 & 2 & 0 & 1 \\
\hline $1,2,3,7,8,9-\mathrm{HXCDF}$ & $\mathrm{ng} / \mathrm{kg}$ & 1 & 1 & 2 & 2 & 2 & 1 & 0 & 0 \\
\hline $\begin{array}{l}1,2,3,7,8- \\
\text { PENTACHLORODIBENZOFURAN }\end{array}$ & $\mathrm{ng} / \mathrm{kg}$ & 0 & 0 & 0 & 0 & 0 & 0 & 0 & 0 \\
\hline $\begin{array}{l}\text { 1,2,3,7,8-PENTACHLORODIBENZO- } \\
\text { P-DIOXIN }\end{array}$ & $\mathrm{ng} / \mathrm{kg}$ & 1 & 1 & 2 & 1 & 1 & 1 & 0 & 1 \\
\hline $2,3,4,6,7,8-\mathrm{HXCDF}$ & $\mathrm{ng} / \mathrm{kg}$ & 0 & 1 & 1 & 1 & 2 & 1 & 0 & 0 \\
\hline 2,3,4,7,8-PECDF & $\mathrm{ng} / \mathrm{kg}$ & 1 & 1 & 0 & 0 & 0 & 1 & 0 & 0 \\
\hline $2,3,7,8-\mathrm{TCDD}$ & $\mathrm{ng} / \mathrm{kg}$ & 1 & 1 & 0 & 0 & 1 & 0 & 0 & 0 \\
\hline $\begin{array}{l}2,3,7,8- \\
\text { TETRACHLORODIBENZOFURAN }\end{array}$ & $\mathrm{ng} / \mathrm{kg}$ & 0 & 0 & 0 & 0 & 1 & 0 & 0 & 0 \\
\hline OCDD & $\mathrm{ng} / \mathrm{kg}$ & 1545 & 5817 & 9548 & 8214 & 5599 & 617 & 2685 & 1081 \\
\hline OCDF & $\mathrm{ng} / \mathrm{kg}$ & 18 & 22 & 11904 & 67 & 91 & 50 & 15 & 24 \\
\hline TCDD TEQ & $\mathrm{ng} / \mathrm{kg}$ & 9 & 12 & 284 & 15 & 8 & 2 & 2 & 2 \\
\hline 1,1'-Biphenyl & $\begin{array}{l}\mathrm{UG} / \\
\mathrm{KG}\end{array}$ & 0 & 0 & 0 & 0 & 0 & 0 & 0 & 1 \\
\hline
\end{tabular}




\begin{tabular}{|c|c|c|c|c|c|c|c|c|c|}
\hline 1-METHYLNAPHTHALENE & $\begin{array}{l}\mathrm{UG} / \\
\mathrm{KG}\end{array}$ & 0 & 0 & 0 & 0 & 0 & 0 & 0 & 2 \\
\hline 2-METHYLNAPHTHALENE & $\begin{array}{l}\mathrm{UG} / \\
\mathrm{KG}\end{array}$ & 0 & 0 & 0 & 0 & 0 & 0 & 0 & 3 \\
\hline ACENAPHTHENE & $\begin{array}{l}\text { UG/ } \\
\text { KG }\end{array}$ & 9 & 0 & 0 & 0 & 0 & 0 & 0 & 2 \\
\hline ACENAPHTHYLENE & $\mathrm{ug} / \mathrm{kg}$ & 0 & 3 & 0 & 0 & 0 & 0 & 0 & 4 \\
\hline ANTHRACENE & $\mathrm{ug} / \mathrm{kg}$ & 14 & 4 & 3 & 5 & 0 & 0 & 0 & 18 \\
\hline AZOBENZENE & $\begin{array}{l}\mathrm{UG} / \\
\mathrm{KG}\end{array}$ & 0 & 0 & 0 & 0 & 0 & 0 & 0 & 0 \\
\hline BENZO(A)ANTHRACENE & $\mathrm{ug} / \mathrm{kg}$ & 29 & 11 & 12 & 5 & 13 & 5 & 5 & 42 \\
\hline BENZO(A)PYRENE & $\mathrm{ug} / \mathrm{kg}$ & 25 & 4 & 11 & 3 & 10 & 5 & 6 & 102 \\
\hline BENZO(B)FLUORANTHENE & $\mathrm{ug} / \mathrm{kg}$ & 31 & 10 & 13 & 3 & 18 & 6 & 10 & 184 \\
\hline Benzo(e)pyrene & $\mathrm{ug} / \mathrm{kg}$ & 13 & 3 & 8 & 3 & 8 & 4 & 7 & 94 \\
\hline BENZO(G,H,I)PERYLENE & $\mathrm{ug} / \mathrm{kg}$ & 13 & 2 & 7 & 2 & 5 & 4 & 5 & 218 \\
\hline BENZO(K)FLUORANTHENE & $\mathrm{ug} / \mathrm{kg}$ & 10 & 4 & 5 & 3 & 8 & 4 & 3 & 35 \\
\hline bis(2-Ethylhexyl)phthalate & $\mathrm{ug} / \mathrm{kg}$ & 0 & 0 & 0 & 0 & 0 & 0 & 0 & 0 \\
\hline Butylbenzylphthalate & $\mathrm{ug} / \mathrm{kg}$ & 0 & 0 & 0 & 0 & 0 & 0 & 0 & 0 \\
\hline Chrysene & $\mathrm{ug} / \mathrm{kg}$ & 31 & 11 & 11 & 4 & 12 & 6 & 11 & 51 \\
\hline Di-n-butylphthalate & $\mathrm{ug} / \mathrm{kg}$ & 0 & 0 & 0 & 0 & 0 & 0 & 0 & 0 \\
\hline DIBENZO(A,H)ANTHRACENE & $\mathrm{ug} / \mathrm{kg}$ & 4 & 0 & 3 & 0 & 0 & 0 & 0 & 52 \\
\hline Di-n-octylphthalate & $\mathrm{ug} / \mathrm{kg}$ & 0 & 0 & 0 & 0 & 0 & 0 & 0 & 0 \\
\hline FLUORANTHENE & $\mathrm{ug} / \mathrm{kg}$ & 71 & 19 & 22 & 10 & 21 & 10 & 14 & 63 \\
\hline FLUORENE & $\mathrm{ug} / \mathrm{kg}$ & 6 & 0 & 0 & 0 & 0 & 0 & 0 & 1 \\
\hline INDENO(1,2,3-CD)PYRENE & $\mathrm{ug} / \mathrm{kg}$ & 13 & 3 & 6 & 2 & 7 & 3 & 5 & 123 \\
\hline $\begin{array}{l}\text { METHANAMINE, N-METHYL-N- } \\
\text { NITROSO }\end{array}$ & $\begin{array}{l}\mathrm{UG} / \\
\mathrm{KG}\end{array}$ & 0 & 0 & 0 & 0 & 0 & 0 & 0 & 0 \\
\hline NAPHTHALENE & $\begin{array}{l}\mathrm{UG} / \\
\mathrm{KG}\end{array}$ & 0 & 0 & 0 & 0 & 0 & 0 & & 3 \\
\hline
\end{tabular}




\begin{tabular}{|c|c|c|c|c|c|c|c|c|c|}
\hline PHENANTHRENE & $\mathrm{ug} / \mathrm{kg}$ & 62 & 9 & 9 & 10 & 11 & 3 & 7 & 58 \\
\hline PYRENE & $\mathrm{ug} / \mathrm{kg}$ & 64 & 15 & 20 & 9 & 17 & 9 & 11 & 51 \\
\hline Aroclor 1016 & $\begin{array}{l}\text { UG/ } \\
\text { KG }\end{array}$ & 0 & 0 & 0 & 0 & 0 & 0 & 0 & 0 \\
\hline Aroclor 1221 & $\begin{array}{l}\text { UG/ } \\
\text { KG }\end{array}$ & 0 & 0 & 0 & 0 & 0 & 0 & 0 & 0 \\
\hline Aroclor 1232 & $\begin{array}{l}\mathrm{UG} / \\
\mathrm{KG}\end{array}$ & 0 & 0 & 0 & 0 & 0 & 0 & 0 & 0 \\
\hline Aroclor 1242 & $\begin{array}{l}\mathrm{UG} / \\
\mathrm{KG}\end{array}$ & 0 & 0 & 0 & 0 & 0 & 0 & 0 & 0 \\
\hline Aroclor 1248 & $\begin{array}{l}\mathrm{UG} / \\
\mathrm{KG}\end{array}$ & 0 & 0 & 0 & 0 & 0 & 0 & 0 & 0 \\
\hline Aroclor 1254 & $\mathrm{ug} / \mathrm{kg}$ & 8 & 3 & 13 & 4 & 5 & 5 & 2 & 9 \\
\hline Aroclor 1260 & $\mathrm{ug} / \mathrm{kg}$ & 4 & 6 & 3 & 2 & 5 & 607 & 1 & 5 \\
\hline Aroclor 1262 & $\begin{array}{l}\text { UG/ } \\
\text { KG }\end{array}$ & 0 & 0 & 0 & 0 & 0 & 0 & 0 & 0 \\
\hline Aroclor 1268 & $\begin{array}{l}\mathrm{UG} / \\
\mathrm{KG}\end{array}$ & 0 & 0 & 0 & 0 & 0 & 0 & 0 & 0 \\
\hline Aroclor 5432 & $\begin{array}{l}\mathrm{UG} / \\
\mathrm{KG} \\
\end{array}$ & 0 & 0 & 0 & 0 & 0 & 0 & 0 & 0 \\
\hline Aroclor 5442 & $\begin{array}{l}\mathrm{UG} / \\
\mathrm{KG}\end{array}$ & 0 & 0 & 0 & 0 & 0 & 0 & 0 & 0 \\
\hline Aroclor 5460 & $\mathrm{ug} / \mathrm{kg}$ & 26 & 21 & 32 & 1 & 13 & 7 & 0 & 7 \\
\hline EFH (C12-C14) & $\begin{array}{l}\text { MG/ } \\
\text { KG }\end{array}$ & 0 & 0 & 0 & 0 & 0 & 0 & 0 & 1 \\
\hline EFH (C15-C20) & $\begin{array}{l}\text { MG/ } \\
\mathrm{KG} \\
\end{array}$ & 0 & 3 & 1 & 1 & 2 & 0 & 0 & 1 \\
\hline EFH (C21-C30) & $\begin{array}{l}\mathrm{mg} / \mathrm{k} \\
\mathrm{g}\end{array}$ & 5 & 4 & 10 & 6 & 3 & 2 & 4 & 5 \\
\hline EFH (C30-C40) & $\begin{array}{l}\mathrm{mg} / \mathrm{k} \\
\mathrm{g}\end{array}$ & 19 & 17 & 9 & 6 & 11 & 3 & 8 & 6 \\
\hline EFH (C8-C11) & MG/ & 0 & 0 & 0 & 0 & 0 & 0 & 0 & 0 \\
\hline
\end{tabular}




\begin{tabular}{|c|c|c|c|c|c|c|c|c|c|c|}
\hline & KG & & & & & & & & & \\
\hline \multicolumn{11}{|l|}{ Oct/244 days } \\
\hline Chemical & $\begin{array}{l}\text { Unit } \\
\text { of } \\
\text { Meas } \\
\text { ure }\end{array}$ & \multicolumn{9}{|c|}{ Standard Error of the Mean } \\
\hline $\begin{array}{l}1,2,3,4,6,7,8- \\
\text { HEPTACHLORODIBENZO-P- } \\
\text { DIOXIN }\end{array}$ & $\mathrm{ng} / \mathrm{kg}$ & 2718 & 339 & 768 & 297 & 1297 & 248 & 482 & 255 & 103 \\
\hline $1,2,3,4,6,7,8-\mathrm{HPCDF}$ & $\mathrm{ng} / \mathrm{kg}$ & 370 & 10 & 51 & 35 & 8 & 13 & 22 & 12 & 7 \\
\hline $1,2,3,4,7,8,9-\mathrm{HPCDF}$ & $\mathrm{ng} / \mathrm{kg}$ & 24 & 1 & 3 & 2 & 1 & 2 & 2 & 1 & 0 \\
\hline $\begin{array}{l}\text { 1,2,3,4,7,8-HEXACHLORODIBENZO- } \\
\text { P-DIOXIN }\end{array}$ & $\mathrm{ng} / \mathrm{kg}$ & 10 & 1 & 3 & 2 & 1 & 1 & 3 & 0 & 0 \\
\hline $1,2,3,4,7,8-\mathrm{HXCDF}$ & $\mathrm{ng} / \mathrm{kg}$ & 5 & 0 & 1 & 1 & 0 & 1 & 2 & 1 & 1 \\
\hline $\begin{array}{l}1,2,3,6,7,8 \text {-HEXACHLORODIBENZO- } \\
\text { P-DIOXIN }\end{array}$ & $\mathrm{ng} / \mathrm{kg}$ & 115 & 10 & 23 & 11 & 26 & 5 & 17 & 4 & 2 \\
\hline $1,2,3,6,7,8-\mathrm{HXCDF}$ & $\mathrm{ng} / \mathrm{kg}$ & 5 & 0 & 1 & 1 & 1 & 0 & 0 & 0 & 0 \\
\hline $\begin{array}{l}\text { 1,2,3,7,8,9-HEXACHLORODIBENZO- } \\
\text { P-DIOXIN }\end{array}$ & $\mathrm{ng} / \mathrm{kg}$ & 24 & 2 & 6 & 2 & 8 & 2 & 6 & 1 & 1 \\
\hline $1,2,3,7,8,9-\mathrm{HXCDF}$ & $\mathrm{ng} / \mathrm{kg}$ & 2 & 0 & 0 & 0 & 0 & 0 & 0 & 1 & 0 \\
\hline $\begin{array}{l}1,2,3,7,8- \\
\text { PENTACHLORODIBENZOFURAN }\end{array}$ & $\mathrm{ng} / \mathrm{kg}$ & 1 & 0 & 0 & 1 & 0 & 0 & 0 & 0 & 0 \\
\hline $\begin{array}{l}\text { 1,2,3,7,8-PENTACHLORODIBENZO- } \\
\text { P-DIOXIN }\end{array}$ & $\mathrm{ng} / \mathrm{kg}$ & 5 & 1 & 1 & 1 & 1 & 1 & 3 & 0 & 0 \\
\hline $2,3,4,6,7,8-\mathrm{HXCDF}$ & $\mathrm{ng} / \mathrm{kg}$ & 12 & 1 & 2 & 1 & 0 & 1 & 2 & 0 & 0 \\
\hline 2,3,4,7,8-PECDF & $\mathrm{ng} / \mathrm{kg}$ & 2 & 1 & 1 & 0 & 0 & 0 & 0 & 0 & 1 \\
\hline $2,3,7,8-\mathrm{TCDD}$ & $\mathrm{ng} / \mathrm{kg}$ & 1 & 0 & 0 & 1 & 0 & 0 & 1 & 0 & 0 \\
\hline $\begin{array}{l}2,3,7,8- \\
\text { TETRACHLORODIBENZOFURAN }\end{array}$ & $\mathrm{ng} / \mathrm{kg}$ & 0 & 0 & 0 & 0 & 0 & 0 & 0 & 0 & 0 \\
\hline OCDD & $\mathrm{ng} / \mathrm{kg}$ & 21586 & 2092 & 4029 & 5886 & 6572 & 3006 & 8164 & 5188 & 939 \\
\hline
\end{tabular}




\begin{tabular}{|c|c|c|c|c|c|c|c|c|c|c|}
\hline OCDF & $\mathrm{ng} / \mathrm{kg}$ & 963 & 30 & 151 & 107 & 29 & 47 & 33 & 43 & 29 \\
\hline TCDD TEQ & $\mathrm{ng} / \mathrm{kg}$ & 121 & 4 & 12 & 5 & 18 & 4 & 13 & 5 & 2 \\
\hline 1,1'-Biphenyl & $\begin{array}{l}\text { UG/ } \\
\text { KG }\end{array}$ & 0 & 0 & 0 & 0 & 0 & 0 & 0 & 0 & 0 \\
\hline 1-METHYLNAPHTHALENE & $\begin{array}{l}\text { UG/ } \\
\text { KG }\end{array}$ & 4 & 2 & 3 & 2 & 5 & 2 & 2 & 0 & 27 \\
\hline 2-METHYLNAPHTHALENE & $\begin{array}{l}\text { UG/ } \\
\text { KG }\end{array}$ & 4 & 1 & 4 & 2 & 4 & 1 & 3 & 0 & 35 \\
\hline ACENAPHTHENE & $\begin{array}{l}\text { UG/ } \\
\text { KG }\end{array}$ & 5 & 0 & 3 & 7 & 34 & 3 & 2 & 0 & 1 \\
\hline ACENAPHTHYLENE & $\mathrm{ug} / \mathrm{kg}$ & 3 & 1 & 3 & 0 & 1 & 2 & 2 & 0 & 7 \\
\hline ANTHRACENE & $\mathrm{ug} / \mathrm{kg}$ & 5 & 8 & 4 & 4 & 38 & 4 & 2 & 0 & 40 \\
\hline AZOBENZENE & $\begin{array}{l}\mathrm{UG} / \\
\mathrm{KG}\end{array}$ & 0 & 0 & 0 & 0 & 0 & 0 & 0 & 0 & 0 \\
\hline BENZO(A)ANTHRACENE & $\mathrm{ug} / \mathrm{kg}$ & 6 & 94 & 11 & 12 & 66 & 15 & 5 & 3 & 116 \\
\hline BENZO(A)PYRENE & $\mathrm{ug} / \mathrm{kg}$ & 3 & 58 & 8 & 11 & 57 & 13 & 4 & 0 & 275 \\
\hline BENZO(B)FLUORANTHENE & $\mathrm{ug} / \mathrm{kg}$ & 13 & 87 & 15 & 15 & 69 & 18 & 5 & 2 & 384 \\
\hline Benzo(e)pyrene & $\mathrm{ug} / \mathrm{kg}$ & 10 & 37 & 15 & 15 & 33 & 17 & 10 & 0 & 193 \\
\hline BENZO(G,H,I)PERYLENE & $\mathrm{ug} / \mathrm{kg}$ & 1 & 22 & 3 & 5 & 30 & 8 & 1 & 3 & 129 \\
\hline BENZO(K)FLUORANTHENE & $\mathrm{ug} / \mathrm{kg}$ & 7 & 36 & 6 & 7 & 33 & 7 & 3 & 0 & 114 \\
\hline bis(2-Ethylhexyl)phthalate & $\mathrm{ug} / \mathrm{kg}$ & 39 & 22 & 19 & 21 & 117 & 24 & 20 & 20 & 93 \\
\hline Butylbenzylphthalate & $\mathrm{ug} / \mathrm{kg}$ & 0 & 0 & 15 & 0 & 0 & 15 & 0 & 0 & 0 \\
\hline Chrysene & $\mathrm{ug} / \mathrm{kg}$ & 23 & 104 & 25 & 15 & 66 & 18 & 9 & 1 & 206 \\
\hline Di-n-butylphthalate & $\mathrm{ug} / \mathrm{kg}$ & 18 & 34 & 0 & 30 & 0 & 0 & 0 & 0 & 0 \\
\hline DIBENZO(A,H)ANTHRACENE & $\mathrm{ug} / \mathrm{kg}$ & 0 & 9 & 2 & 3 & 10 & 4 & 0 & 0 & 36 \\
\hline Di-n-octylphthalate & $\mathrm{ug} / \mathrm{kg}$ & 0 & 0 & 0 & 0 & 0 & 0 & 0 & 0 & 22 \\
\hline FLUORANTHENE & $\mathrm{ug} / \mathrm{kg}$ & 97 & 166 & 40 & 27 & 145 & 29 & 38 & 0 & 296 \\
\hline FLUORENE & $\mathrm{ug} / \mathrm{kg}$ & 5 & 0 & 2 & 5 & 24 & 2 & 2 & 0 & 2 \\
\hline INDENO(1,2,3-CD)PYRENE & $\mathrm{ug} / \mathrm{kg}$ & 2 & 23 & 3 & 5 & 29 & 7 & 1 & 0 & 164 \\
\hline
\end{tabular}




\begin{tabular}{|c|c|c|c|c|c|c|c|c|c|c|}
\hline $\begin{array}{l}\text { METHANAMINE, N-METHYL-N- } \\
\text { NITROSO }\end{array}$ & $\begin{array}{l}\mathrm{UG} / \\
\mathrm{KG}\end{array}$ & 0 & 0 & 0 & 0 & 0 & 0 & 0 & 0 & 0 \\
\hline NAPHTHALENE & $\begin{array}{l}\mathrm{UG} / \\
\mathrm{KG}\end{array}$ & 3 & 2 & 2 & 2 & 29 & 2 & 2 & 0 & 22 \\
\hline PHENANTHRENE & $\mathrm{ug} / \mathrm{kg}$ & 64 & 30 & 32 & 30 & 161 & 18 & 24 & 0 & 239 \\
\hline PYRENE & $\mathrm{ug} / \mathrm{kg}$ & 65 & 152 & 32 & 24 & 122 & 20 & 26 & 0 & 114 \\
\hline Aroclor 1016 & $\begin{array}{l}\mathrm{UG} / \\
\mathrm{KG}\end{array}$ & 0 & 0 & 0 & 4 & 0 & 0 & 0 & 0 & 0 \\
\hline Aroclor 1221 & $\begin{array}{l}\mathrm{UG} / \\
\mathrm{KG}\end{array}$ & 0 & 0 & 0 & 0 & 0 & 0 & 0 & 0 & 0 \\
\hline Aroclor 1232 & $\begin{array}{l}\mathrm{UG} / \\
\mathrm{KG}\end{array}$ & 0 & 0 & 0 & 0 & 0 & 0 & 0 & 0 & 0 \\
\hline Aroclor 1242 & $\begin{array}{l}\mathrm{UG} / \\
\mathrm{KG}\end{array}$ & 0 & 0 & 0 & 0 & 0 & 0 & 0 & 0 & 0 \\
\hline Aroclor 1248 & $\begin{array}{l}\mathrm{UG} / \\
\mathrm{KG}\end{array}$ & 0 & 0 & 0 & 0 & 0 & 0 & 0 & 0 & 0 \\
\hline Aroclor 1254 & $\mathrm{ug} / \mathrm{kg}$ & 7 & 7 & 10 & 6 & 16 & 3 & 5 & 14 & 1 \\
\hline Aroclor 1260 & $\mathrm{ug} / \mathrm{kg}$ & 4 & 7 & 5 & 2 & 3 & 2 & 4 & 5 & 1 \\
\hline Aroclor 1262 & $\begin{array}{l}\mathrm{UG} / \\
\mathrm{KG}\end{array}$ & 0 & 0 & 0 & 0 & 0 & 0 & 0 & 0 & 0 \\
\hline Aroclor 1268 & $\begin{array}{l}\mathrm{UG} / \\
\mathrm{KG}\end{array}$ & 0 & 0 & 0 & 0 & 0 & 0 & 0 & 0 & 0 \\
\hline Aroclor 5432 & $\begin{array}{l}\mathrm{UG} / \\
\mathrm{KG}\end{array}$ & 0 & 0 & 0 & 0 & 0 & 0 & 0 & 0 & 0 \\
\hline Aroclor 5442 & $\begin{array}{l}\mathrm{UG} / \\
\mathrm{KG}\end{array}$ & 0 & 0 & 0 & 0 & 0 & 0 & 0 & 0 & 0 \\
\hline Aroclor 5460 & $\mathrm{ug} / \mathrm{kg}$ & 10 & 3 & 4 & 5 & 4 & 11 & 14 & 24 & 0 \\
\hline EFH (C12-C14) & $\begin{array}{l}\text { MG/ } \\
\text { KG }\end{array}$ & 0 & N/A & 0 & 0 & N/A & 0 & 0 & 0 & 0 \\
\hline EFH (C15-C20) & $\begin{array}{l}\mathrm{MG} / \\
\mathrm{KG}\end{array}$ & 3 & N/A & 4 & 13 & N/A & 2 & 0 & 0 & 10 \\
\hline EFH (C21-C30) & $\mathrm{mg} / \mathrm{k}$ & 12 & N/A & 4 & 24 & N/A & 5 & 10 & 7 & 27 \\
\hline
\end{tabular}




\begin{tabular}{|l|l|l|l|l|l|l|l|l|l|l|}
\hline & $\mathrm{g}$ & & & & & & & & & \\
\hline EFH (C30-C40) & $\begin{array}{l}\mathrm{mg} / \mathrm{k} \\
\mathrm{g}\end{array}$ & 40 & N/A & 7 & 62 & N/A & 15 & 26 & 18 & 48 \\
\hline EFH (C8-C11) & $\begin{array}{l}\text { MG/ } \\
\text { KG }\end{array}$ & 0 & N/A & 0 & 0 & N/A & 0 & 0 & 0 & 0 \\
\hline
\end{tabular}


Table 20: Total EFH concentration in microcosms during incubation

\begin{tabular}{|c|c|c|c|c|c|c|c|c|c|c|}
\hline & Time & NUTR & SOLE & RICE & AUGM & COMB & UNAA & UNAB & UNAC & STER \\
\hline \multirow[b]{3}{*}{$\begin{array}{l}\text { Average } \\
(\mathrm{mg} / \mathrm{kg})\end{array}$} & $\begin{array}{l}\mathrm{Feb} / 0 \\
\text { days }\end{array}$ & 182 & 1640 & 154 & 146 & 1980 & 152 & 230 & 100 & 101 \\
\hline & $\begin{array}{l}\text { Jun/126 } \\
\text { days }\end{array}$ & 152 & 172 & 137 & 113 & 156 & 89 & 226 & 105 & N/A \\
\hline & $\begin{array}{l}\text { Oct/244 } \\
\text { days }\end{array}$ & 152 & N/A & 502 & 556 & N/A & 502 & 1589 & 558 & 628 \\
\hline \multirow{3}{*}{$\begin{array}{l}\text { Standard } \\
\text { Deviation } \\
(\mathrm{mg} / \mathrm{kg})\end{array}$} & $\begin{array}{l}\mathrm{Feb} / 0 \\
\text { days }\end{array}$ & 51 & 219 & 21 & 23 & 327 & 55 & 12 & 29 & 9 \\
\hline & $\begin{array}{l}\text { Jun/126 } \\
\text { days }\end{array}$ & 54 & 54 & 46 & 27 & 32 & 12 & 30 & 26 & N/A \\
\hline & $\begin{array}{l}\text { Oct/244 } \\
\text { days }\end{array}$ & 119 & N/A & 502 & 556 & N/A & 79 & 188 & 54 & 42 \\
\hline \multirow[b]{3}{*}{$\begin{array}{l}\text { Standard Error } \\
(\mathrm{mg} / \mathrm{kg})\end{array}$} & $\begin{array}{l}\mathrm{Feb} / 0 \\
\text { days }\end{array}$ & 23 & 98 & 9 & 10 & 146 & 25 & 5 & 13 & 4 \\
\hline & $\begin{array}{l}\text { Jun/126 } \\
\text { days }\end{array}$ & 24 & 24 & 20 & 12 & 14 & 5 & 14 & 12 & N/A \\
\hline & $\begin{array}{l}\text { Oct/244 } \\
\text { days }\end{array}$ & 53 & N/A & 225 & 248 & N/A & 35 & 84 & 24 & 19 \\
\hline
\end{tabular}


Table 21: Total PAH concentration in microcosms during incubation

\begin{tabular}{|c|c|c|c|c|c|c|c|c|c|c|}
\hline & Time & NUTR & SOLE & RICE & AUGM & COMB & UNAA & UNAB & UNAC & STER \\
\hline \multirow[t]{3}{*}{$\begin{array}{l}\text { Average } \\
(\mu \mathrm{g} / \mathrm{kg})\end{array}$} & $\begin{array}{l}\mathrm{Feb} / 0 \\
\text { days }\end{array}$ & 626 & 350 & 714 & 214 & 87 & 467 & 45139 & 626 & 523 \\
\hline & $\begin{array}{l}\text { Jun/126 } \\
\text { days }\end{array}$ & 727 & 538 & 489 & 382 & 485 & 429 & 39238 & 153 & N/A \\
\hline & $\begin{array}{l}\text { Oct } / 244 \\
\text { days }\end{array}$ & 673 & 1390 & 759 & 710 & 1672 & 684 & 40585 & 50 & 943 \\
\hline \multirow{3}{*}{$\begin{array}{l}\text { Standard } \\
\text { Deviation } \\
(\mu \mathrm{g} / \mathrm{kg})\end{array}$} & $\begin{array}{l}\text { Feb/0 } \\
\text { days }\end{array}$ & 228 & 191 & 414 & 34 & 56 & 297 & 3441 & 1361 & 364 \\
\hline & $\begin{array}{l}\text { Jun/126 } \\
\text { days }\end{array}$ & 882 & 195 & 282 & 113 & 282 & 158 & 1746 & 211 & N/A \\
\hline & $\begin{array}{l}\text { Oct } / 244 \\
\text { days }\end{array}$ & 714 & 1812 & 372 & 479 & 2014 & 224 & 5198 & 50 & 289 \\
\hline \multirow[t]{3}{*}{$\begin{array}{l}\text { Standard Error } \\
(\mu \mathrm{g} / \mathrm{kg})\end{array}$} & $\begin{array}{l}\text { Feb/0 } \\
\text { days }\end{array}$ & 102 & 85 & 185 & 15 & 25 & 133 & 1539 & 609 & 163 \\
\hline & $\begin{array}{l}\text { Jun/126 } \\
\text { days }\end{array}$ & 394 & 87 & 126 & 50 & 126 & 71 & 781 & 94 & N/A \\
\hline & $\begin{array}{l}\text { Oct/244 } \\
\text { days }\end{array}$ & 319 & 810 & 166 & 214 & 901 & 100 & 2325 & 23 & 129 \\
\hline
\end{tabular}


Table 22: Aroclor 1260, 5460, and 1254 concentrations in microcosms during incubation

\begin{tabular}{|c|c|c|c|c|c|c|c|c|c|c|}
\hline \multicolumn{2}{|l|}{ AROCLOR 1260} & NUTR & SOLE & RICE & AUGM & COMB & UNAA & UNAB & UNAC & STER \\
\hline \multirow[b]{3}{*}{ Average $(\mu \mathrm{g} / \mathrm{kg})$} & Feb/0 days & 97 & 108 & 110 & 110 & 103 & 328 & 111 & 37 & 112 \\
\hline & Jun/126 days & 128 & 116 & 120 & 118 & 126 & 121 & 143 & 38 & N/A \\
\hline & Oct/244 days & 77 & 66 & 65 & 78 & 69 & 80 & 22 & 95 & 70 \\
\hline \multirow{3}{*}{$\begin{array}{l}\text { Standard Deviation } \\
(\mu \mathrm{g} / \mathrm{kg})\end{array}$} & Feb/0 days & 11 & 9 & 7 & 26 & 6 & 596 & 8 & 3 & 14 \\
\hline & Jun/126 days & 8 & 13 & 7 & 4 & 11 & 7 & 13 & 2 & N/A \\
\hline & Oct/244 days & 8 & 16 & 12 & 4 & 6 & 9 & 2 & 11 & 5 \\
\hline \multirow{3}{*}{$\begin{array}{l}\text { Standard Error } \\
(\mu \mathrm{g} / \mathrm{kg})\end{array}$} & Feb/0 days & 5 & 4 & 3 & 12 & 3 & 266 & 3 & 1 & 6 \\
\hline & Jun/126 days & 4 & 6 & 3 & 2 & 5 & 607 & 5 & 1 & N/A \\
\hline & Oct/244 days & 4 & 7 & 5 & 2 & 3 & 4 & 1 & 5 & 2 \\
\hline \multicolumn{2}{|l|}{ AROCLOR 5460} & NUTR & SOLE & RICE & AUGM & COMB & UNAA & UNAB & UNAC & STER \\
\hline \multirow[b]{3}{*}{ Average $(\mu \mathrm{g} / \mathrm{kg})$} & Feb/0 days & 97 & 191 & 142 & 108 & 93 & 908 & 102 & 0 & 80 \\
\hline & Jun/126 days & 87 & 89 & 92 & 58 & 81 & 70 & 112 & 0 & N/A \\
\hline & Oct/244 days & 73 & 61 & 59 & 81 & 71 & 106 & 0 & 91 & 77 \\
\hline \multirow{3}{*}{$\begin{array}{l}\text { Standard Deviation } \\
(\mu \mathrm{g} / \mathrm{kg})\end{array}$} & Feb/0 days & 52 & 201 & 86 & 41 & 11 & 2300 & 46 & 0 & 4 \\
\hline & Jun/126 days & 59 & 47 & 72 & 3 & 29 & 20 & 17 & 0 & \\
\hline & Oct/244 days & 23 & 7 & 10 & 12 & 9 & 30 & 0 & 53 & 25 \\
\hline \multirow{3}{*}{$\begin{array}{l}\text { Standard Error } \\
(\mu \mathrm{g} / \mathrm{kg})\end{array}$} & Feb/0 days & 23 & 90 & 38 & 18 & 5 & 1029 & 21 & 0 & 2 \\
\hline & Jun/126 days & 26 & 21 & 32 & 1 & 13 & 7 & 7 & 0 & \\
\hline & Oct/244 days & 10 & 3 & 4 & 5 & 4 & 14 & 0 & 24 & 11 \\
\hline
\end{tabular}




\begin{tabular}{|c|c|c|c|c|c|c|c|c|c|c|}
\hline \multicolumn{2}{|l|}{ AROCLOR 1254} & NUTR & SOLE & RICE & AUGM & COMB & UNAA & UNAB & UNAC & STER \\
\hline \multirow[b]{3}{*}{ Average $(\mu \mathrm{g} / \mathrm{kg})$} & Feb/0 days & 132 & 150 & 142 & 160 & 140 & 645 & 127 & 59 & 132 \\
\hline & Jun/126 days & 71 & 73 & 74 & 58 & 85 & 69 & 137 & 59 & \\
\hline & Oct/244 days & 65 & 70 & 63 & 77 & 77 & 78 & 29 & 75 & 70 \\
\hline \multirow{3}{*}{$\begin{array}{l}\text { Standard Deviation } \\
(\mu \mathrm{g} / \mathrm{kg})\end{array}$} & Feb/0 days & 23 & 16 & 15 & 64 & 12 & 1358 & 12 & 5 & 15 \\
\hline & Jun/126 days & 19 & 6 & 28 & 8 & 12 & 12 & 23 & 4 & \\
\hline & Oct/244 days & 15 & 15 & 22 & 13 & 35 & 11 & 2 & 31 & 7 \\
\hline \multirow{3}{*}{$\begin{array}{l}\text { Standard Error } \\
(\mu \mathrm{g} / \mathrm{kg})\end{array}$} & Feb/0 days & 10 & 7 & 7 & 29 & 5 & 607 & 5 & 2 & 7 \\
\hline & Jun/126 days & 8 & 3 & 13 & 4 & 5 & 5 & 9 & 2 & \\
\hline & Oct/244 days & 7 & 7 & 10 & 6 & 16 & 5 & 1 & 14 & 3 \\
\hline
\end{tabular}


Table 23: Total dioxin concentration in microcosms during incubation

\begin{tabular}{|c|c|c|c|c|c|c|c|c|c|c|}
\hline & Time & NUTR & SOLE & RICE & AUGM & COMB & UNAA & UNAB & UNAC & STER \\
\hline \multirow{3}{*}{ Average (ng/kg) } & Feb/0 days & 98898 & 99547 & 89064 & 116316 & 100358 & 99432 & 26581 & 54509 & 91803 \\
\hline & Jun/126 days & 79230 & 84227 & 85548 & 90113 & 88368 & 81967 & 26041 & 54526 & N/A \\
\hline & Oct/244 days & 126710 & 88048 & 93723 & 85415 & 97854 & 96257 & 30452 & 55342 & 99035 \\
\hline \multirow{3}{*}{ Standard Deviation (ng/kg) } & Feb/0 days & 11141 & 6749 & 6327 & 51418 & 13966 & 9032 & 1536 & 7608 & 18189 \\
\hline & Jun/126 days & 3779 & 14579 & 19916 & 20613 & 12666 & 2047 & 2396 & 6219 & N/A \\
\hline & Oct/244 days & 57719 & 4316 & 11257 & 85415 & 17633 & 19335 & 2397 & 12275 & 7052 \\
\hline \multirow{3}{*}{ Standard Error (ng/kg) } & Feb/0 days & 4982 & 3018 & 2830 & 22995 & 6246 & 4039 & 687 & 3403 & 8135 \\
\hline & Jun/126 days & 1690 & 6520 & 8907 & 9219 & 5665 & 915 & 1072 & 2781 & N/A \\
\hline & Oct/244 days & 25813 & 1930 & 5034 & 38199 & 7886 & 8647 & 1072 & 5490 & 3154 \\
\hline
\end{tabular}


Table 24: TCDD TEQ in microcosms during incubation

\begin{tabular}{|c|c|c|c|c|c|c|c|c|c|c|}
\hline & Time & NUTR & SOLE & RICE & AUGM & COMB & UNAA & UNAB & UNAC & STER \\
\hline \multirow{3}{*}{$\begin{array}{l}\text { Average } \\
\text { (ng/kg) }\end{array}$} & $\begin{array}{l}\text { Feb/0 } \\
\text { days }\end{array}$ & 297 & 303 & 267 & 332 & 286 & 288 & 57 & 55 & 266 \\
\hline & $\begin{array}{l}\text { Jun/126 } \\
\text { days }\end{array}$ & 247 & 264 & 250 & 266 & 262 & 264 & 54 & 56 & N/A \\
\hline & $\begin{array}{l}\text { Oct/244 } \\
\text { days }\end{array}$ & 247 & 264 & 276 & 282 & 314 & 309 & 67 & 62 & 314 \\
\hline \multirow{3}{*}{$\begin{array}{l}\text { Standard } \\
\text { Deviation } \\
(\mathrm{ng} / \mathrm{kg})\end{array}$} & $\begin{array}{l}\text { Feb/0 } \\
\text { days }\end{array}$ & 28 & 27 & 18 & 137 & 33 & 13 & 2 & 7 & 18 \\
\hline & $\begin{array}{l}\text { Jun/126 } \\
\text { days }\end{array}$ & 20 & 27 & 15 & 34 & 19 & 4 & 2 & 5 & N/A \\
\hline & $\begin{array}{l}\text { Oct/244 } \\
\text { days }\end{array}$ & 137 & 10 & 28 & 11 & 41 & 30 & 4 & 11 & 8 \\
\hline \multirow{3}{*}{$\begin{array}{l}\text { Standard Error } \\
(\mathrm{ng} / \mathrm{kg})\end{array}$} & $\begin{array}{l}\text { Feb/0 } \\
\text { days }\end{array}$ & 13 & 12 & 8 & 61 & 15 & 6 & 1 & 3 & 8 \\
\hline & $\begin{array}{l}\text { Jun/126 } \\
\text { days }\end{array}$ & 9 & 12 & 7 & 15 & 8 & 2 & 1 & 2 & N/A \\
\hline & $\begin{array}{l}\text { Oct/244 } \\
\text { days }\end{array}$ & 61 & 4 & 12 & 5 & 18 & 13 & 2 & 5 & 4 \\
\hline
\end{tabular}


Appendix L: Raw Soil Gas Data

\begin{tabular}{|c|c|c|c|c|c|c|c|}
\hline $\begin{array}{l}\text { Depth (ft- } \\
\text { bgs) }\end{array}$ & $\begin{array}{c}\mathrm{CO} 2 \\
(\%)\end{array}$ & $\begin{array}{c}\mathrm{CO2} \\
\text { Average } \\
(\%)\end{array}$ & $\begin{array}{c}\text { CO2 St Dev } \\
(\%)\end{array}$ & $\mathrm{O} 2(\%)$ & $\begin{array}{c}\text { O2 Average } \\
(\%)\end{array}$ & $\begin{array}{c}\text { O2 St Dev } \\
(\%)\end{array}$ & Date Collected \\
\hline 5 & 0.8 & 1.761363636 & 2.446375193 & 20 & 18.27727273 & 3.505534736 & Jun-14 \\
\hline 5 & 0.8 & & & 18.8 & & & Jun-14 \\
\hline 5 & 0.7 & & & 20.3 & & & Jun-14 \\
\hline 5 & 0.9 & & & 20 & & & Jun-14 \\
\hline 5 & 1.7 & & & 19 & & & Jun-14 \\
\hline 5 & 1.6 & & & 19.5 & & & Jun-14 \\
\hline 5 & 11.8 & & & 5.6 & & & Jun-14 \\
\hline 5 & 4 & & & 16.8 & & & Jun-14 \\
\hline 5 & 0 & & & 20.3 & & & Jun-14 \\
\hline 5 & 0 & & & 20.1 & & & Jun-14 \\
\hline 5 & 0.1 & & & 19.9 & & & Jun-14 \\
\hline 5.5 & 3.4 & & & 17.4 & & & Jun-14 \\
\hline 5.5 & 1 & & & 19.8 & & & Jun-14 \\
\hline 5.5 & 1 & & & 19.8 & & & Jun-14 \\
\hline 5.5 & 2.4 & & & 18.8 & & & Jun-14 \\
\hline 5.5 & 0.7 & & & 19.6 & & & Jun-14 \\
\hline 5.5 & 0.4 & & & 19.8 & & & Jun-14 \\
\hline 5.5 & 0.4 & & & 19 & & & Jun-14 \\
\hline 5.5 & 3.1 & & & 17.1 & & & Jun-14 \\
\hline 5.5 & 10.3 & & & 2.1 & & & Jun-14 \\
\hline 5.5 & 2.7 & & & 16.9 & & & Jun-14 \\
\hline 5.5 & 0.4 & & & 19.7 & & & Jun-14 \\
\hline 5.5 & 0.1 & & & 18.1 & & & Jun-14 \\
\hline 5.5 & 1 & & & 20 & & & Jun-14 \\
\hline
\end{tabular}




\begin{tabular}{|c|c|c|c|c|c|c|c|}
\hline 5.5 & 1 & & & 19.9 & & & Jun-14 \\
\hline 5.5 & 0.8 & & & 20.2 & & & Jun-14 \\
\hline 5.5 & 0.3 & & & 20.5 & & & Jun-14 \\
\hline 5.5 & 1.5 & & & 19.2 & & & Jun-14 \\
\hline 5.5 & 2.4 & & & 18.6 & & & Jun-14 \\
\hline 5.5 & 0 & & & 19.2 & & & Jun-14 \\
\hline 5.5 & 2.4 & & & 18.4 & & & Jun-14 \\
\hline 5.5 & 0.5 & & & 19.8 & & & Jun-14 \\
\hline 5.5 & 3.9 & & & 16.4 & & & Jun-14 \\
\hline 5.5 & 0.1 & & & 20.1 & & & Jun-14 \\
\hline 5.5 & 2 & & & 18.6 & & & Jun-14 \\
\hline 5.5 & 4.6 & & & 14.2 & & & Jun-14 \\
\hline 5.5 & 0.2 & & & 19.9 & & & Jun-14 \\
\hline 5.5 & 0.3 & & & 20 & & & Jun-14 \\
\hline 5.5 & 0.2 & & & 19.5 & & & Jun-14 \\
\hline 5.5 & 0 & & & 20.1 & & & Jun-14 \\
\hline 5.5 & 1.4 & & & 18.2 & & & Jun-14 \\
\hline 5.5 & 0.7 & & & 19 & & & Jun-14 \\
\hline 5.6 & 0.7 & & & 19.2 & & & Jun-14 \\
\hline 5.75 & 5.2 & & & 14.8 & & & Jun-14 \\
\hline 6 & 0.9 & 1.986666667 & 1.524966822 & 20 & 16.91333333 & 5.014958576 & Jun-14 \\
\hline 6 & 0.9 & & & 19.8 & & & Jun-14 \\
\hline 6 & 0.9 & & & 19.8 & & & Jun-14 \\
\hline 6 & 0.6 & & & 19.6 & & & Jun-14 \\
\hline 6 & 2.4 & & & 15 & & & Jun-14 \\
\hline 6 & 1.5 & & & 19.5 & & & Jun-14 \\
\hline 6 & 2.2 & & & 18.1 & & & Jun-14 \\
\hline 6 & 4.5 & & & 13.3 & & & Jun-14 \\
\hline 6.5 & 0 & & & 17.8 & & & Jun-14 \\
\hline
\end{tabular}




\begin{tabular}{|c|c|c|c|c|c|c|c|}
\hline 6.5 & 1 & & & 20.1 & & & Jun-14 \\
\hline 6.5 & 1.9 & & & 0.3 & & & Jun-14 \\
\hline 6.5 & 5 & & & 16.2 & & & Jun-14 \\
\hline 6.5 & 3.9 & & & 17 & & & Jun-14 \\
\hline 6.5 & 0.9 & & & 19.2 & & & Jun-14 \\
\hline 6.5 & 3.2 & & & 18 & & & Jun-14 \\
\hline 7 & 1.5 & 2.14 & 1.360042016 & 18.8 & 17.43333333 & 3.894990678 & Jun-14 \\
\hline 7 & 3.2 & & & 17.6 & & & Jun-14 \\
\hline 7 & 1 & & & 19.8 & & & Jun-14 \\
\hline 7 & 0.5 & & & 19.4 & & & Jun-14 \\
\hline 7.5 & 4 & & & 16.8 & & & Jun-14 \\
\hline 7.5 & 3.4 & & & 17.8 & & & Jun-14 \\
\hline 7.5 & 0.8 & & & 19.4 & & & Jun-14 \\
\hline 7.5 & 2.1 & & & 4.1 & & & Jun-14 \\
\hline 7.5 & 3.2 & & & 17.1 & & & Jun-14 \\
\hline 7.5 & 3 & & & 18.5 & & & Jun-14 \\
\hline 7.5 & 1.2 & & & 19.6 & & & Jun-14 \\
\hline 7.5 & 1.2 & & & 19.2 & & & Jun-14 \\
\hline 7.5 & 0 & & & 20.1 & & & Jun-14 \\
\hline 7.5 & 2.6 & & & 17.5 & & & Jun-14 \\
\hline 7.5 & 4.4 & & & 15.8 & & & Jun-14 \\
\hline 8 & 0.6 & 1.533333333 & 1.41509717 & 19.8 & 18.43333333 & 1.188486432 & Jun-14 \\
\hline 8 & 1.4 & & & 18.2 & & & Jun-14 \\
\hline 8 & 2 & & & 18.5 & & & Jun-14 \\
\hline 8.5 & 2 & & & 17.4 & & & Jun-14 \\
\hline 8.5 & 0.4 & & & 19.8 & & & Jun-14 \\
\hline 8.5 & 0 & & & 18.6 & & & Jun-14 \\
\hline 8.5 & 0.1 & & & 19.7 & & & Jun-14 \\
\hline 8.5 & 3.5 & & & 16.5 & & & Jun-14 \\
\hline
\end{tabular}




\begin{tabular}{|c|c|c|c|c|c|c|c|}
\hline 8.9 & 3.8 & & & 17.4 & & & Jun-14 \\
\hline 9 & 5.8 & 2.875 & 2.526361019 & 12.7 & 17.225 & 3.348009359 & Jun-14 \\
\hline 9 & 1.6 & & & 19.5 & & & Jun-14 \\
\hline 9.5 & 0.1 & & & 20 & & & Jun-14 \\
\hline 9.5 & 4 & & & 16.7 & & & Jun-14 \\
\hline 10 & 1.3 & 3.007692308 & 3.202983385 & 19.1 & 15.5 & 6.232976817 & Jun-14 \\
\hline 10 & 0.1 & & & 18.5 & & & Jun-14 \\
\hline 10.5 & 4.6 & & & 15.9 & & & Jun-14 \\
\hline 10.5 & 7.9 & & & 0 & & & Jun-14 \\
\hline 10.5 & 8.3 & & & 6.7 & & & Jun-14 \\
\hline 10.5 & 1.2 & & & 19.3 & & & Jun-14 \\
\hline 10.5 & 2.8 & & & 18.3 & & & Jun-14 \\
\hline 10.5 & 0 & & & 18.5 & & & Jun-14 \\
\hline 10.5 & 1.8 & & & 18.6 & & & Jun-14 \\
\hline 10.5 & 8.1 & & & 9 & & & Jun-14 \\
\hline 10.5 & 0.1 & & & 19.7 & & & Jun-14 \\
\hline 10.5 & 0 & & & 19.9 & & & Jun-14 \\
\hline 10.6 & 2.9 & & & 18 & & & Jun-14 \\
\hline 11 & 1.4 & 2.45 & 1.711306936 & 18.7 & 17.5125 & 1.589642817 & Jun-14 \\
\hline 11 & 4.5 & & & 15.8 & & & Jun-14 \\
\hline 11 & 0 & & & 20.2 & & & Jun-14 \\
\hline 11.08 & 0.8 & & & 19 & & & Jun-14 \\
\hline 11.5 & 4.9 & & & 16.4 & & & Jun-14 \\
\hline 11.5 & 2.9 & & & 16.1 & & & Jun-14 \\
\hline 11.5 & 2.9 & & & 16.8 & & & Jun-14 \\
\hline 11.5 & 2.2 & & & 17.1 & & & Jun-14 \\
\hline 12 & 5.2 & 3.24 & 2.154762168 & 15 & 13.88 & 8.053384382 & Jun-14 \\
\hline 12 & 4 & & & 0 & & & Jun-14 \\
\hline 12.5 & 2 & & & 18.8 & & & Jun-14 \\
\hline
\end{tabular}




\begin{tabular}{|c|c|c|c|c|c|c|c|}
\hline 12.5 & 0.1 & & & 20.1 & & & Jun-14 \\
\hline 12.5 & 4.9 & & & 15.5 & & & Jun-14 \\
\hline 13 & 0 & 1.22 & 1.62080227 & 20 & 18.44 & 1.494322589 & Jun-14 \\
\hline 13.3 & 1.5 & & & 18.3 & & & Jun-14 \\
\hline 13.5 & 0.7 & & & 19.6 & & & Jun-14 \\
\hline 13.5 & 3.9 & & & 16.2 & & & Jun-14 \\
\hline 13.5 & 0 & & & 18.1 & & & Jun-14 \\
\hline 14.5 & 1 & & & 15.9 & & & Jun-14 \\
\hline 15.5 & 5.9 & 4.014285714 & 4.490519113 & 14.4 & 14.48571429 & 6.862562343 & Jun-14 \\
\hline 15.5 & 12.7 & & & 0 & & & Jun-14 \\
\hline 15.5 & 1.2 & & & 19.4 & & & Jun-14 \\
\hline 15.5 & 0 & & & 16.8 & & & Jun-14 \\
\hline 15.5 & 5.1 & & & 13.3 & & & Jun-14 \\
\hline 15.5 & 0 & & & 20.4 & & & Jun-14 \\
\hline 15.6 & 3.2 & & & 17.1 & & & Jun-14 \\
\hline 16 & 1.6 & & & 19 & & & Jun-14 \\
\hline 17.5 & 0 & & & 20 & & & Jun-14 \\
\hline 18.5 & 3.2 & 2.4 & 1.13137085 & 16.5 & 16.55 & 0.070710678 & Jun-14 \\
\hline 18.5 & 1.6 & & & 16.6 & & & Jun-14 \\
\hline 19 & 4.6 & & & 16.2 & & & Jun-14 \\
\hline 20.5 & 6.1 & 6.3 & 3.772929896 & 14.1 & 10.12 & 7.748354664 & Jun-14 \\
\hline 20.5 & 9.9 & & & 0 & & & Jun-14 \\
\hline 20.5 & 0 & & & 20.6 & & & Jun-14 \\
\hline 20.5 & 7.9 & & & 9.1 & & & Jun-14 \\
\hline 20.5 & 7.6 & & & 6.8 & & & Jun-14 \\
\hline 25.5 & 0.6 & & & 19.4 & & & Jun-14 \\
\hline 25.5 & 7.7 & & & 6.8 & & & Jun-14 \\
\hline 30.5 & 7.7 & & & 0 & & & Jun-14 \\
\hline 40.5 & 1.4 & & & 0 & & & Jun-14 \\
\hline
\end{tabular}


Appendix M: Kinetics Estimations Using Microcosm Data

Notes: Kinetics calculations were only performed for average concentrations that showed a reduction in COI concentrations over the duration of the microcosm study. Standard error was not considered for these calculations. To review calculations, see Excel file 'graphs for thesis and kinetics_MB_19Dec2014.xlsx'.

Table 25: EFH kinetics estimate

\begin{tabular}{|l|r|r|r|r|}
\hline EFH & \multicolumn{1}{|l|}{ UNAA } & \multicolumn{1}{l|}{ AUGM } & \multicolumn{1}{l|}{ RICE } & \multicolumn{1}{l|}{ NUTR } \\
\hline Feb/0 days & 152 & 146 & 154 & 182 \\
\hline Jun/126 days & 89.4 & 113.4 & 137.2 & 151.6 \\
\hline $\begin{array}{l}\text { First-Order Reaction Constant } \\
(1 / \mathrm{d})\end{array}$ & $4.2 \mathrm{E}-03$ & $2.0 \mathrm{E}-03$ & $9.2 \mathrm{E}-04$ & $1.5 \mathrm{E}-03$ \\
\hline $\begin{array}{l}\text { Time to reach LUT (First-Order), } \\
\text { days }\end{array}$ & $7.8 \mathrm{E}+02$ & $1.6 \mathrm{E}+03$ & $3.6 \mathrm{E}+03$ & $2.4 \mathrm{E}+03$ \\
\hline $\begin{array}{l}\text { Time to reach LUT (First-Order), } \\
\text { years }\end{array}$ & $\mathbf{2 . 1}$ & $\mathbf{4 . 4}$ & $\mathbf{9 . 9}$ & $\mathbf{6 . 5}$ \\
\hline $\begin{array}{l}\text { Zero-Order Reaction Constant } \\
\text { (ppm/d) }\end{array}$ & $5.0 \mathrm{E}-01$ & $2.6 \mathrm{E}-01$ & $1.3 \mathrm{E}-01$ & $2.4 \mathrm{E}-01$ \\
\hline $\begin{array}{l}\text { Time to reach LUT (Zero-Order), } \\
\text { days }\end{array}$ & $2.9 \mathrm{E}+02$ & $5.4 \mathrm{E}+02$ & $1.1 \mathrm{E}+03$ & $7.3 \mathrm{E}+02$ \\
\hline $\begin{array}{l}\text { Time to reach LUT (Zero-Order), } \\
\text { years }\end{array}$ & $\mathbf{0 . 8}$ & $\mathbf{1 . 5}$ & $\mathbf{3 . 0}$ & $\mathbf{2 . 0}$ \\
\hline
\end{tabular}


Table 26: PAHs kinetics estimate

\begin{tabular}{|lr|}
\hline & \multicolumn{2}{c|}{ Benzo(a)pyrene in } \\
\hline Feb/0 days & UNAB \\
Oct/244 days & $4.5 \mathrm{E}+03$ \\
First-Order Reaction Constant (1/d) & $3.6 \mathrm{E}+03$ \\
Time to reach LUT (First-Order), days & $8.9 \mathrm{E}-04$ \\
\hline Time to reach LUT (First-Order), years & $7.8 \mathrm{E}+03$ \\
\hline Zero-Order Reaction Constant (ppb/d) & $\mathbf{2 1 . 2}$ \\
Time to reach LUT (Zero-Order), days & $7.0 \mathrm{E}+00$ \\
\hline Time to reach LUT (Zero-Order), years & $6.4 \mathrm{E}+02$ \\
\hline Note: LUT value is BaP TEQ; performed kinetic analysis on Benzo(a)pyrene in Soil B \\
\hline
\end{tabular}


Table 27: PCBs kinetics estimate

\begin{tabular}{|c|c|c|c|c|c|c|c|c|c|}
\hline PCBs & NUTR & SOLE & RICE & AUGM & COMB & UNAA & UNAB & UNAC & STER \\
\hline Feb/0 days & 326.4 & 448.2 & 394 & 378 & 336.2 & 2811.8 & 329.2 & 95.4 & 323.8 \\
\hline Oct/244 days & 215 & 197.4 & 186.2 & 240.2 & 217.8 & 263 & 260.6 & 51.2 & 217 \\
\hline First-Order Reaction Constant (1/d) & $1.7 \mathrm{E}-03$ & $3.4 \mathrm{E}-03$ & $3.1 \mathrm{E}-03$ & $1.9 \mathrm{E}-03$ & $1.8 \mathrm{E}-03$ & $9.7 \mathrm{E}-03$ & $9.6 \mathrm{E}-04$ & $2.6 \mathrm{E}-03$ & $1.6 \mathrm{E}-03$ \\
\hline & $1.1 \mathrm{E}+0$ & $6.3 \mathrm{E}+0$ & $6.5 \mathrm{E}+0$ & $1.1 \mathrm{E}+0$ & $1.0 \mathrm{E}+0$ & $4.1 \mathrm{E}+0$ & $1.9 \mathrm{E}+0$ & $2.3 \mathrm{E}+0$ & $1.1 \mathrm{E}+0$ \\
\hline Time to reach LUT (First-Order), days & 3 & 2 & 2 & 3 & 3 & 2 & 3 & 2 & 3 \\
\hline $\begin{array}{l}\text { Time to reach LUT (First-Order), } \\
\text { years }\end{array}$ & 2.9 & 1.7 & 1.8 & 2.9 & 2.8 & 1.1 & 5.2 & 0.6 & 3.0 \\
\hline Zero-Order Reaction Constant (ppb/d) & 4.6E-01 & $\begin{array}{r}1.0 \mathrm{E}+0 \\
0\end{array}$ & $8.5 \mathrm{E}-01$ & $5.6 \mathrm{E}-01$ & 4.9E-01 & $\begin{array}{r}1.0 \mathrm{E}+0 \\
1\end{array}$ & $2.8 \mathrm{E}-01$ & $1.8 \mathrm{E}-01$ & 4.4E-01 \\
\hline Time to reach LUT (Zero-Order), da & $\begin{array}{r}6.0 \mathrm{E}+0 \\
2\end{array}$ & $\begin{array}{r}3.8 \mathrm{E}+0 \\
2\end{array}$ & $\begin{array}{r}4.0 \mathrm{E}+0 \\
2\end{array}$ & $\begin{array}{r}5.7 \mathrm{E}+0 \\
2\end{array}$ & $\begin{array}{r}5.8 \mathrm{E}+0 \\
2\end{array}$ & $\begin{array}{r}2.6 \mathrm{E}+0 \\
2\end{array}$ & $\begin{array}{r}9.8 \mathrm{E}+0 \\
2\end{array}$ & $\begin{array}{r}2.3 \mathrm{E}+0 \\
2\end{array}$ & $\begin{array}{r}6.2 \mathrm{E}+0 \\
2\end{array}$ \\
\hline $\begin{array}{l}\text { Time to reach LUT (Zero-Order), } \\
\text { years }\end{array}$ & 1.6 & 1.1 & 1.1 & 1.6 & 1.6 & 0.7 & 2.7 & 0.6 & 1.7 \\
\hline
\end{tabular}

Table 28: Dioxins kinetics estimate

\begin{tabular}{|c|c|c|c|}
\hline TCDD TEQ & SOLE & AUGM & NUTR \\
\hline Feb/0 days & 303.4 & 332.2 & 297.2 \\
\hline Oct/244 days & 263.8 & 282 & 247.4 \\
\hline First-Order Reaction Constant (1/d) & 5.7E-04 & $6.7 \mathrm{E}-04$ & 7.5E-04 \\
\hline Time to reach LUT (First-Order), days & $1.0 \mathrm{E}+04$ & $8.8 \mathrm{E}+03$ & $7.7 \mathrm{E}+03$ \\
\hline Time to reach LUT (First-Order), years & 27.8 & 24.1 & 21.1 \\
\hline Zero-Order Reaction Constant (ppt/d) & $1.6 \mathrm{E}-01$ & $2.1 \mathrm{E}-01$ & $2.0 \mathrm{E}-01$ \\
\hline Time to reach LUT (Zero-Order), days & $1.9 \mathrm{E}+03$ & $1.6 \mathrm{E}+03$ & $1.5 \mathrm{E}+03$ \\
\hline Time to reach LUT (Zero-Order), years & 5.1 & 4.4 & 4.0 \\
\hline
\end{tabular}

